In cooperation with the U.S. Department of Defense and Edwards Aquifer Authority

\title{
Conceptualization and Simulation of the Edwards Aquifer, San Antonio Region, Texas
}

Scientific Investigations Report 2004-5277 


\section{Conceptualization and Simulation of the Edwards Aquifer, San Antonio Region, Texas}

By R.J. Lindgren, A.R. Dutton, S.D. Hovorka, S.R.H. Worthington, and Scott Painter

In cooperation with the U.S. Department of Defense and Edwards Aquifer Authority

Scientific Investigations Report 2004-5277 


\title{
U.S. Department of the Interior Gale A. Norton, Secretary
}

\author{
U.S. Geological Survey \\ Charles G. Groat, Director
}

\section{U.S. Geological Survey, Reston, Virginia: 2004}

For sale by U.S. Geological Survey, Information Services

Box 25286, Denver Federal Center

Denver, CO 80225

For more information about the USGS and its products:

Telephone: 1-888-ASK-USGS

World Wide Web: http://www.usgs.gov/

Any use of trade, product, or firm names in this publication is for descriptive purposes only and does not imply endorsement by the U.S. Government.

Although this report is in the public domain, permission must be secured from the individual copyright owners to reproduce any copyrighted materials contained within this report.

Suggested citation:

Lindgren, R.J., Dutton, A.R., Hovorka, S.D., Worthington, S.R.H., and Painter, Scott, 2004, Conceptualization and simulation of the Edwards aquifer, San Antonio region, Texas: U.S. Geological Survey Scientific Investigations Report 2004-5277, 143 p. 


\section{Contents}

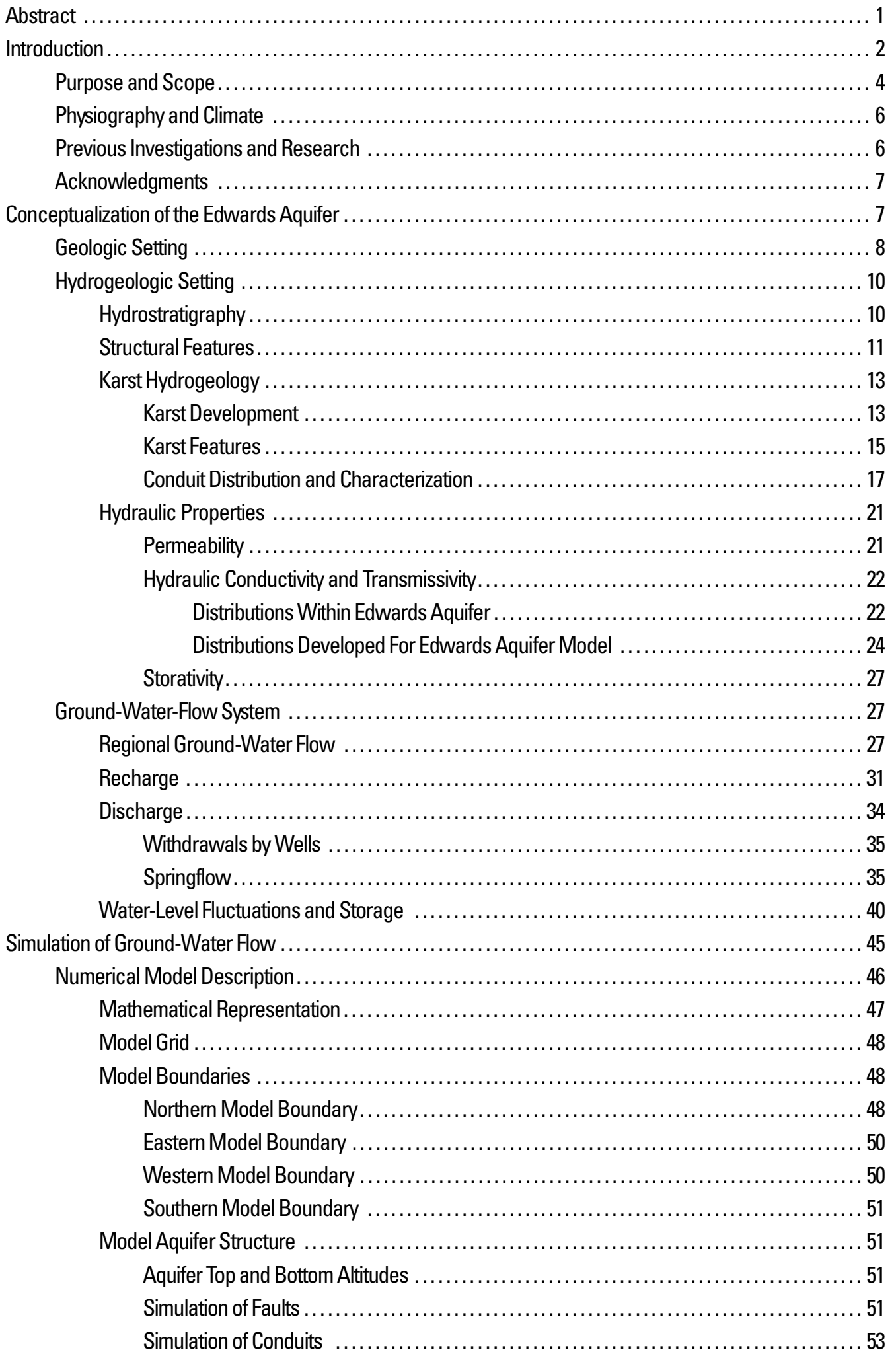




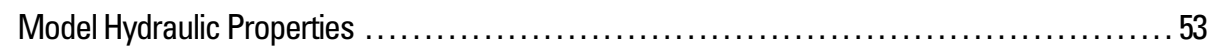

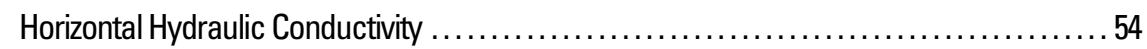

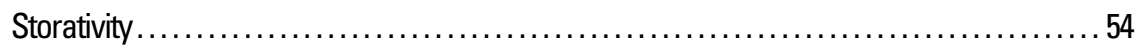

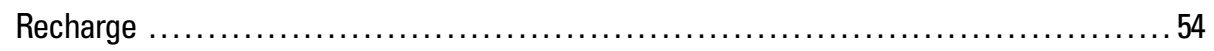

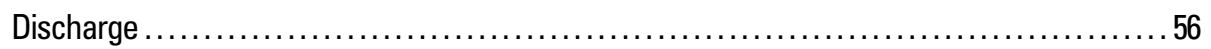

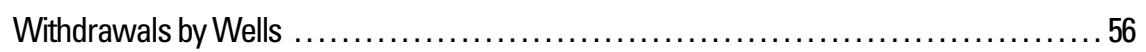

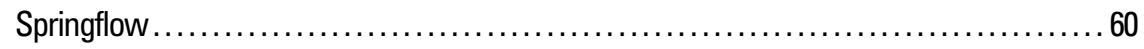

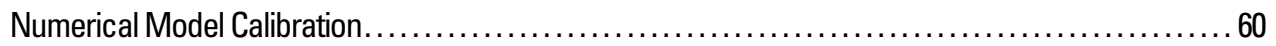

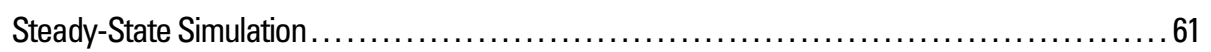

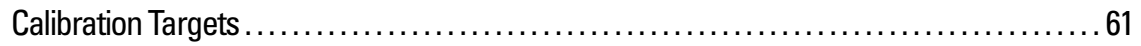

Changes From Initial Values ............................................ 61

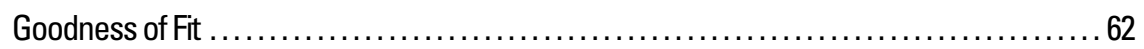

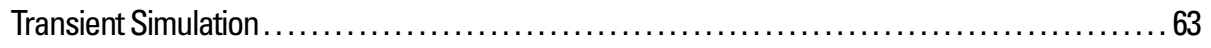

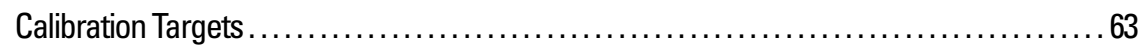

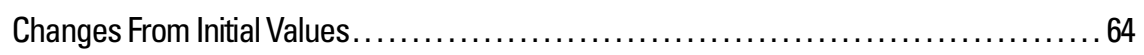

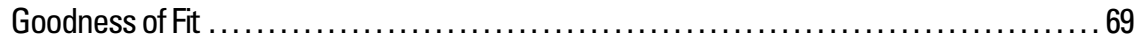

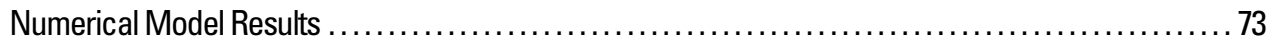

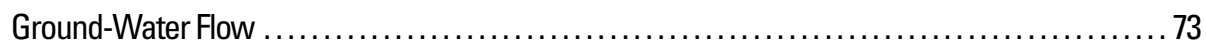

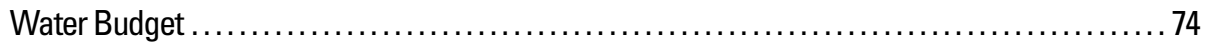

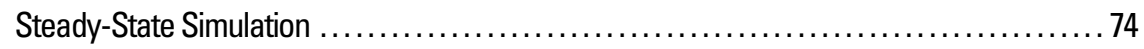

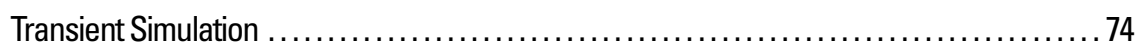

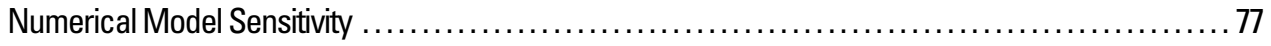

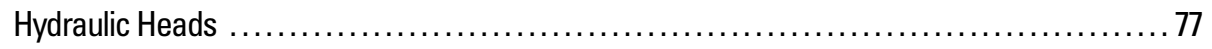

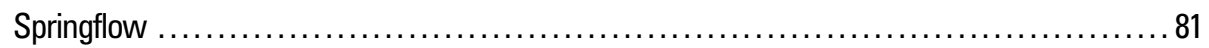

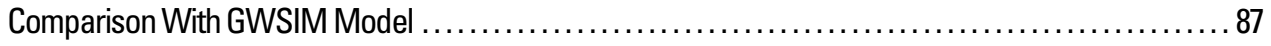

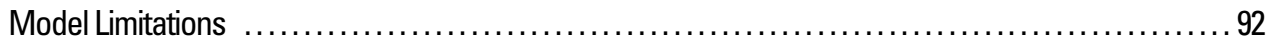

Assumptions For Conceptual and Numerical Models ............................. 93

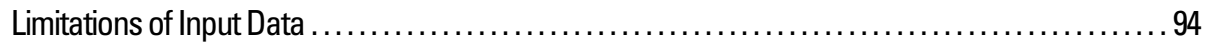

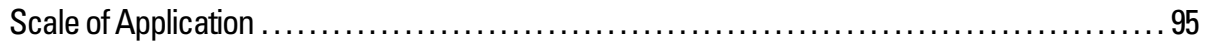

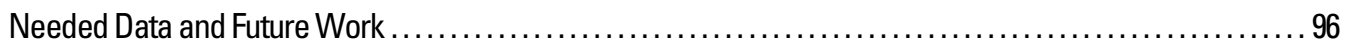

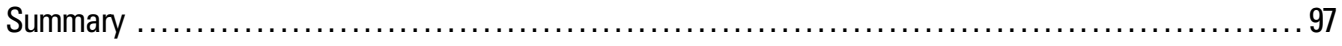

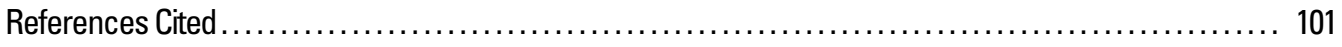

\section{Plates}

1-7. Maps showing:

1. Locations of Edwards aquifer wells with water levels (hydraulic heads) used to calibrate Edwards aquifer model (calibration target wells), San Antonio region, Texas

2. Measured water-level altitude in Edwards aquifer, 1939-46, and simulated altitude of potentiometric surface, steady-state simulation, Edwards aquifer model, San Antonio region, Texas

3. Measured water-level altitude in Edwards aquifer and simulated altitude of potentiometric surface for drought conditions, August 1956 (stress period 117), transient simulation, Edwards aquifer model, San Antonio region, Texas 
4. Measured water-level altitude in Edwards aquifer and simulated altitude of potentiometric surface for above-normal rainfall conditions, February 1975 (stress period 339), transient simulation, Edwards aquifer model, San Antonio region, Texas

5. Simulated flow directions for steady-state simulation (1939-46), Edwards aquifer model, San Antonio region, Texas

6. Simulated flow directions for drought conditions, August 1956 (stress period 117), transient simulation, Edwards aquifer model, San Antonio region, Texas

7. Simulated flow directions for above-normal rainfall conditions, February 1975 (stress period 339), transient simulation, Edwards aquifer model, San Antonio region, Texas

\section{Figures}

1. Map showing location of ground-water-flow model area, Edwards aquifer segments, and physiographic regions, San Antonio region, Texas

2. Map showing hydrogeologic zones and catchment area (upper parts of stream basins that contribute recharge) of the Edwards aquifer, San Antonio region, Texas

3. Map showing paleogeographic and structural features in Texas associated with the Edwards aquifer model area

4. Chart showing correlation of Cretaceous stratigraphic units and hydrogeologic units, and relative permeabilities, in the Edwards aquifer model area, San Antonio region, Texas.......... 9

5. Map showing altitude of the top of the Edwards aquifer (in the subcrop) and fault locations,

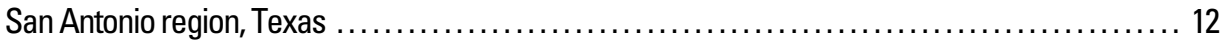

6. Map showing thickness of the Edwards aquifer, San Antonio region, Texas ................ 14

7. Map showing inferred locations of conduits in the Edwards aquifer, San Antonio region,

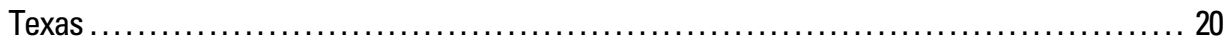

8. Map showing distribution of horizontal hydraulic conductivity for the Edwards aquifer, San Antonio region, Texas 26

9. Diagrammatic north-northwest-to-south-southeast section showing hydrogeologic framework and generalized ground-water-flow directions, Edwards Plateau to Gulf Coastal Plain, San Antonio region, Texas

10. Map showing potentiometric surface and inferred regional ground-water-flow pattern in the Edwards aquifer, October 27-November 2, 2001, San Antonio region, Texas

11. Graphs showing estimated annual recharge (from seepage losses from streams and infiltration of rainfall) to the San Antonio segment of the Edwards aquifer, San Antonio region, Texas, by recharge basin or contributing drainage area, 1934-2003

12. Graphs showing (a) annual ground-water discharge, springflow, and withdrawals, (excluding Travis County); (b) annual withdrawals by water-use category (excluding Travis County); and (c) annual withdrawals by county, in the active model area of the Edwards aquifer, San Antonio region, Texas, 1939-2000

13. Maps showing distributions of annual (a) water use by category and (b) total withdrawals for the Edwards aquifer, San Antonio region, Texas, 1996

14. Hydrograph showing annual measured discharge for major springs in the San Antonio segment of the Edwards aquifer, San Antonio region, Texas, 1939-2000

15. Hydrographs showing measured and simulated water levels (hydraulic heads) for Edwards aquifer wells in (a) Uvalde County and (b) Medina County, San Antonio region, Texas

16. Hydrographs showing measured and simulated water levels (hydraulic heads) for Edwards aquifer wells in Bexar County, San Antonio region, Texas 
17. Hydrographs showing measured and simulated water levels (hydraulic heads) for Edwards aquifer wells in (a) Comal County and (b) Hays County, San Antonio region, Texas

18. Map showing boundary conditions and finite-difference grid for the Edwards aquifer model San Antonio region, Texas

19. Map showing thickness of underlying Trinity aquifer simulated in the Edwards aquifer recharge zone, Edwards aquifer model, San Antonio region, Texas

20. Map showing simulated subzones of the recharge zone of the Edwards aquifer, San Antonio region, Texas

21. Map showing distribution of withdrawals during 1939-46 (steady-state simulation) and 2000, and additional withdrawals for 2000, Edwards aquifer model, San Antonio region, Texas

22. Graph showing variation in monthly percentages of total annual withdrawals for municipal and irrigation withdrawals simulated in the Edwards aquifer model, San Antonio region, Texas 59

23. Graph showing simulated relative to measured hydraulic heads, steady-state simulation, Edwards aquifer model, San Antonio region, Texas.

24. Map showing simulated storativity zones for calibrated Edwards aquifer model, San Antonio region, Texas 65

25. Map showing simulated distribution of horizontal hydraulic conductivity for calibrated Edwards aquifer model, San Antonio region, Texas

26. Map showing simulated distribution of transmissivity for calibrated Edwards aquifer model, San Antonio region, Texas 68

27. Graphs showing simulated relative to measured hydraulic heads for (a) August 1956 (stress period 117) and (b) February 1975 (stress period 339), transient simulation, Edwards aquifer model, San Antonio region, Texas

28. Hydrographs showing measured and simulated springflows for (a) Comal Springs and (b) San Marcos Springs, 1947-2000, Edwards aquifer model, San Antonio region, Texas 71

29. Hydrographs showing measured and simulated springflows for (a) Leona Springs, (b) San Antonio Springs, and (c) San Pedro Springs, 1947-2000, Edwards aquifer model, San Antonio region, Texas

30. Schematic diagram showing simulated water-budget components for (a) steady-state simulation and (b) transient simulation, Edwards aquifer model, San Antonio region, Texas 75

31. Graphs showing simulated water-budget components, as percentages of total sources to and discharges from the Edwards aquifer for (a) drought conditions, 1956, and (b) abovenormal rainfall and recharge conditions, 1975, transient simulation, Edwards aquifer model, San Antonio region, Texas 76

32. Graphs showing sensitivity of simulated hydraulic heads to changes in model parameters at calibration wells for (a) steady-state simulation, (b) drought conditions, August 1956 (stress period 117), transient simulation, and (c) above-normal rainfall and recharge conditions, February 1975 (stress period 339), transient simulation, Edwards aquifer model, San Antonio region, Texas

33. Hydrographs showing sensitivity of simulated hydraulic heads in (a) Bexar County index well $(J-17,6837203)$ and (b) Uvalde County index well $(J-27,6950302)$ to changes in location of the southern model boundary and spring-orifice altitude, Edwards aquifer model, San Antonio region, Texas 
34. Graphs showing sensitivity of simulated springflow to changes in model parameters at simulated springs for (a) steady-state simulation, (b) drought conditions, August 1956 (stress period 117), transient simulation, and (c) above-normal rainfall and recharge conditions, February 1975 (stress period 339), transient simulation, Edwards aquifer model, San Antonio region, Texas.

35. Graph showing sensitivity of simulated springflow to changes in hydraulic conductivity at simulated springs for steady-state simulation, Edwards aquifer model, San Antonio region, Texas 86

36. Hydrographs showing sensitivity of simulated springflow from (a) Comal and (b) Leona Springs to changes in location of the southern model boundary and spring-orifice altitude, Edwards aquifer model, San Antonio region, Texas.

37. Hydrographs showing measured hydraulic heads and simulated hydraulic heads by the Edwards aquifer model, San Antonio region, Texas, and the GWSIM model for (a) Bexar County index well (J-17, 6837203) and (b) Uvalde County index well (J-27, 6950302), 1978-89 . .... 89

38. Hydrographs showing measured springflows and simulated springflows by the Edwards aquifer model, San Antonio region, Texas, and the GWSIM model for Comal Springs for (a) 1947-59 and (b) 1978-89.

39. Hydrographs showing measured springflows and simulated springflows by the Edwards aquifer model, San Antonio region, Texas, and the GWSIM model for San Marcos Springs for (a) 1947-59 and (b) 1978-89

40. Hydrographs showing measured hydraulic heads and simulated hydraulic heads by the Edwards aquifer model, San Antonio region, Texas, and the GWSIM model for Hays County wells (a) 5857902, (b) 5858101, and (c) Uvalde County well 6937402, 1978-89

\section{Tables}

1. Ground-Water-Model Advisory Panel (GWMAP) members and staff ..................... 4

2. Fault displacement and simulated hydraulic characteristic for faults, Edwards aquifer model, San Antonio region, Texas ........................................... 53

3. Estimated recharge rates, by subzone of the recharge zone, Edwards aquifer model, San

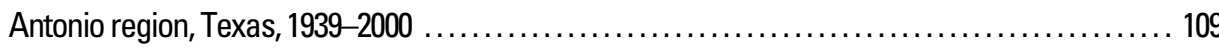

4. Ground-water withdrawals, by county, Edwards aquifer model, San Antonio region, Texas

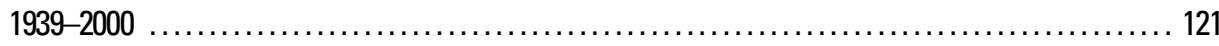

5. Steady-state and transient simulation target wells, Edwards aquifer model, San Antonio

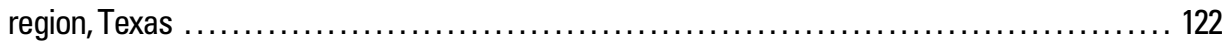

6. Summary of changes from initial values for steady-state calibration, Edwards aquifer model, San Antonio region, Texas .....

7. Estimated and simulated recharge rates, by subzone of the recharge zone, steady-state calibration, Edwards aquifer model, San Antonio region, Texas ....................... 126

8. Steady-state calibration target wells and residuals, Edwards aquifer model, San Antonio region, Texas .

9. Measured and simulated springflows for steady-state calibration, Edwards aquifer model, San Antonio region, Texas

10. Estimated and simulated recharge rates and multiplication factors used for years with greatly above-normal rainfall and recharge, Edwards aquifer model, San Antonio region, Texas.....

11. Initial and final calibrated drain parameters for springs, Edwards aquifer model, San Antonio region, Texas 
12. Summary of changes in parameter values (1) from initial calibrated steady-state simulation, (2) from USGS-estimated recharge rates, and (3) from the initial uniform storativity distribution for the transient simulation; and changes from the calibrated transient simulation for transient simulation testing, Edwards aquifer model, San Antonio region, Texas. 131

13. Transient simulation target wells and residuals for drought conditions, Edwards aquifer model, San Antonio region, Texas

14. Transient simulation target wells and residuals for above-normal rainfall and recharge conditions, Edwards aquifer model, San Antonio region, Texas

15. Simulated water budget for the steady-state simulation and for the transient simulation by monthly stress period for 1956 and 1975, Edwards aquifer model, San Antonio region, Texas .... 140

16. Comparison of the residuals for hydraulic heads and springflows for selected observation wells and springs for the Edwards aquifer model and the GWSIM model, San Antonio region, Texas

\section{Vertical Datum}

Vertical coordinate information is referenced to the National Geodetic Vertical Datum of 1929 (NGVD 29). 


\title{
Conceptualization and Simulation of the Edwards Aquifer, San Antonio Region, Texas
}

\author{
By R.J. Lindgren ${ }^{1}$, A.R. Dutton ${ }^{2}$, S.D. Hovorka ${ }^{3}$, S.R.H. Worthington ${ }^{4}$, and Scott Painter ${ }^{5}$
}

\section{Abstract}

A new numerical ground-water-flow model (Edwards aquifer model) that incorporates important components of the latest information and plausible conceptualization of the Edwards aquifer was developed. The model includes both the San Antonio and Barton Springs segments of the Edwards aquifer in the San Antonio region, Texas, and was calibrated for steady-state (1939-46) and transient (1947-2000) conditions, excluding Travis County. Transient simulations were conducted using monthly recharge and pumpage (withdrawal) data. The model incorporates conduits simulated as continuously connected (other than being separated in eastern Uvalde and southwestern Medina Counties), one-cell-wide (1,320 feet) zones with very large hydraulic-conductivity values (as much as 300,000 feet per day). The locations of the conduits were based on a number of factors, including major potentiometricsurface troughs in the aquifer, the presence of sinking streams, geochemical information, and geologic structures (for example, faults and grabens).

The simulated directions of flow in the Edwards aquifer model are most strongly influenced by the presence of simulated conduits and barrier faults. The simulated flow in the Edwards aquifer is influenced by the locations of the simulated conduits, which tend to facilitate flow. The simulated subregional flow directions generally are toward the nearest conduit and subsequently along the conduits from the recharge zone into the confined zone and toward the major springs. Structures simulated in the Edwards aquifer model influencing groundwater flow that tend to restrict flow are barrier faults. The influence of simulated barrier faults on flow directions is most evident in northern Medina County.

\footnotetext{
${ }^{1}$ U.S. Geological Survey.

${ }^{2}$ The University of Texas at San Antonio.

${ }^{3}$ The University of Texas at Austin, Bureau of Economic Geology.

${ }^{4}$ Worthington Groundwater, Dundas, Ontario, Canada.

${ }^{5}$ Southwest Research Institute, San Antonio, Texas.
}

A water budget is an accounting of inflow to, outflow from, and storage change in the aquifer. For the Edwards aquifer model steady-state simulation, recharge (from seepage losses from streams and infiltration of rainfall) accounts for 93.5 percent of the sources of water to the Edwards aquifer, and inflow through the northern and northwestern model boundaries contributes 6.5 percent. The largest discharges are springflow (73.7 percent) and ground-water withdrawals by wells (25.7 percent).

The principal source of water to the Edwards aquifer for the Edwards aquifer model transient simulation was recharge, constituting about 60 percent of the sources of water (excluding change in storage) to the Edwards aquifer during 1956, a drought period, and about 97 percent of the sources (excluding change in storage) during 1975, a period of above-normal rainfall and recharge. The principal discharges from the Edwards aquifer for the transient simulation were springflow and withdrawals by wells. During 1956, representing drought conditions, the change in storage (net water released from storage) was much greater than recharge, accounting for 75.9 percent of the total flow compared to 14.5 percent for recharge. Conversely, during 1975, representing above-normal rainfall and recharge conditions, recharge constituted 79.9 percent of the total flow, compared to 7.1 percent for the change in storage (net water added to storage).

A series of sensitivity tests was made to ascertain how the model results were affected by variations greater than and less than the calibrated values of input data. Simulated hydraulic heads in the Edwards aquifer model were most sensitive to recharge, withdrawals, hydraulic conductivity of the conduit segments, and specific yield and were comparatively insensitive to spring-orifice conductance, northern boundary inflow, and specific storage. Simulated springflow in the Edwards aquifer model was most sensitive to recharge, withdrawals, hydraulic conductivity of the conduit segments, specific yield, and increases in northern boundary inflow and was comparatively insensitive to spring-orifice conductance and specific storage. 


\section{Conceptualization and Simulation of the Edwards Aquifer, San Antonio Region, Texas}

\section{Introduction}

The Edwards aquifer in the Balcones fault zone of southcentral Texas (fig. 1) is one of the most permeable and most productive aquifers in the world. The aquifer consists of regionally extensive carbonate rocks that crop out within the Edwards Plateau and the Balcones fault zone and underlie the Gulf Coastal Plain. The northern aquifer boundary is defined by the updip limit of contiguous, outcropping rocks of the Edwards Group, Georgetown Formation, and their westward stratigraphic equivalents (Edwards rocks) and the southern boundary by the updip boundary of the freshwater/saline-water transition zone (commonly referred to as the freshwater/saline-water interface and defined on maps as the 1,000-milligrams per liter $[\mathrm{mg} / \mathrm{L}]$ dissolved solids concentration line). The San Antonio segment of the aquifer primarily includes all or parts of Kinney, Uvalde, Medina, Bexar, Comal, and Hays Counties that lie within and adjacent to the Balcones fault zone (fig. 1). This segment is bounded on the west and east by ground-water divides near Brackettville and Kyle, respectively, and contains the most productive and transmissive parts of the aquifer. The Barton Springs segment of the aquifer includes parts of Hays and Travis Counties and is bounded on the southwest by the groundwater divide near Kyle and on the northeast by the Colorado River. The San Antonio segment of the aquifer discharges primarily to Comal and San Marcos Springs, whereas the Barton Springs segment discharges primarily to Barton Springs (fig. 1).

The competition for ground water from the Edwards aquifer has created some controversial water issues in central Texas. Designated a sole-source aquifer in the San Antonio and Austin areas by the U.S. Environmental Protection Agency (2003), the aquifer is critical to farming and ranching economies west of San Antonio and recreational economies northeast of the city. Comal and San Marcos Springs and their effluent streams (rivers) (fig. 1) support seven Federally listed endangered and one threatened species (Edwards Aquifer Authority, 2004a). The Barton Springs salamander, listed as an endangered species, is restricted to the region immediately surrounding that spring. Water-resource managers are concerned that drought or increasing demand for ground water, or both, might result in the deterioration of habitats for several of the endangered species (Edwards Aquifer Authority, 2004a). Most groundwater-management scenarios must, therefore, address Federal mandates to protect endangered species whose habitats depend upon a complex combination of biologic as well as hydrogeologic processes.

A better understanding of the hydrogeologic processes that control the distribution and availability of water in the Edwards aquifer is imperative for optimal resource management. Optimizing the use of the aquifer while ensuring that present and future needs are satisfied is the ultimate goal for the region (Edwards Aquifer Authority, 2004b). The optimization concept of managing the Edwards aquifer involves a procedure for aquifer use that enables the greatest number of the desired benefits to be accomplished. For water-resource managers to develop and implement effective long-range and short-range aquifer management strategies, a host of scientific questions must be answered. These questions can best be answered through a comprehensive process that integrates the best scientific data available.

To evaluate the hydrologic response to various alternative proposals for managing the Edwards aquifer, the Edwards Aquifer Authority (EAA, formerly the Edwards Underground Water District), with other San Antonio water-resource managers and planners, expressed the need for an improved numerical ground-water-flow model. Rather than attempt to update, modify, or recalibrate existing models, it was decided that a new, comprehensive ground-water-flow model, using contemporary user-friendly, pre- and post-processing software that incorporated important components of the latest conceptualization of the aquifer was needed. To develop an improved model, a study was conducted from 2000 to 2003 by the U.S. Geological Survey (USGS) and The University of Texas at Austin, Bureau of Economic Geology (BEG), in cooperation with the U.S. Department of Defense and the EAA. The objective of this study was to improve understanding of the complex hydrogeologic processes that control water availability of the Edwards aquifer in the San Antonio area through the development, calibration, and testing of a numerical ground-water-flow model that can be used in decision processes to optimize resource management. To accomplish this, all available and pertinent hydrogeologic data were compiled and organized into a comprehensive, digital-based system of data storage and retrieval. The new Edwards aquifer numerical ground-water-flow model developed in this study (hereinafter, the Edwards aquifer model) incorporates improvements over previous models by using (1) a user-friendly interface, (2) updated computer codes (MODFLOW96 and MODFLOW2000), (3) a finer grid resolution, (4) less-restrictive boundary conditions, (5) an improved discretization of hydraulic conductivity, (6) more accurate estimates of pumping stresses, (7) a long transient simulation period (54 years, 1947-2000), and (8) a refined representation of zones of large hydraulic conductivity, or conduits. In addition, the Edwards aquifer model produces a closer match between simulated and measured hydraulic heads for a larger area of the San Antonio segment of the Edwards aquifer, and between simulated and measured springflows, than do previous numerical ground-water-flow models.

During the initial phases of the project planning and implementation, a panel of advisors was formed, hereinafter termed the Ground-Water-Model Advisory Panel (GWMAP), to provide technical input, primarily for conceptualization, but also for the construction and calibration of the Edwards aquifer model. The members of the GWMAP and their affiliations are listed in table 1 . The intent was to deliver an end product (Edwards aquifer model) that had been critiqued, as it was developed, by the ground-water community concerned with the Edwards aquifer in the San Antonio region, as represented by the GWMAP. The GWMAP met periodically during the development of the model, providing comments, suggestions, and technical direction. Technical issues and concerns causing 


\section{EXPLANATION}

Active ground-water-model are

$\square$ San Antonio segment

Barton Springs segment

Inactive ground-water-model area

Depositional province (modified from Maclay, 1995, fig. 2)

- Boundary of Balcones fault zone

\lceil\rceil$\rceil$ Balcones escarpment (modified from Abbott and Woodruff, 1986, fig. 1)

$\rightarrow$ Spring

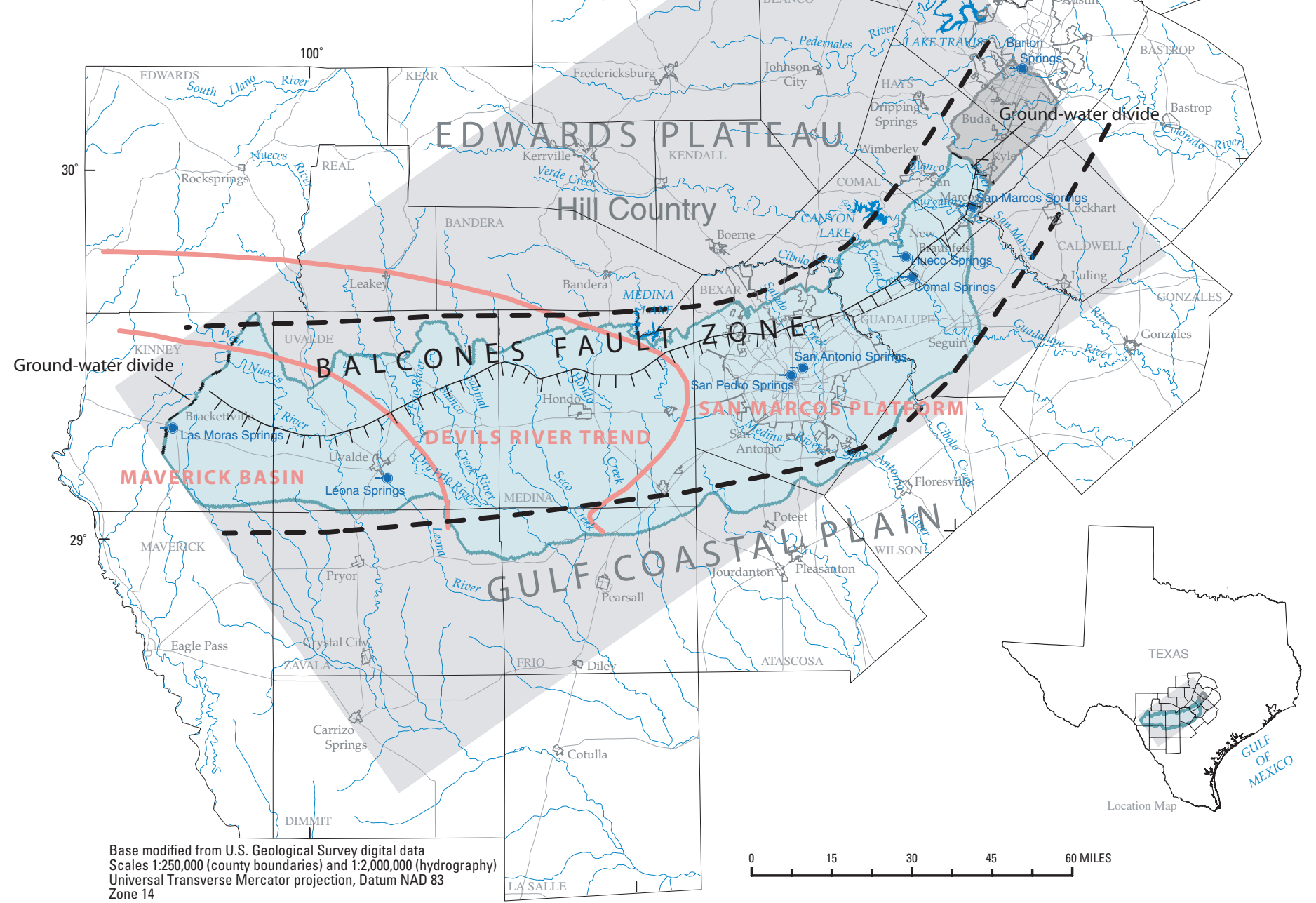

Figure 1. Location of ground-water-flow model area, Edwards aquifer segments, and physiographic regions, San Antonio region, Texas. 


\section{Conceptualization and Simulation of the Edwards Aquifer, San Antonio Region, Texas}

Table 1. Ground-Water-Model Advisory Panel (GWMAP) members and staff.

\begin{tabular}{|l|l|}
\hline \multicolumn{1}{|c|}{ GWMAP member } & \multicolumn{1}{c|}{ Affiliation } \\
\hline Geary M. Schindel (Chairman) & Edwards Aquifer Authority \\
\hline E. Calvin Alexander, Jr. & University of Minnesota \\
\hline Andy Donnelly & LBG-Guyton Associates \\
\hline Ronald Green & Southwest Research Institute, CNWRA \\
\hline John Kain & HQ AETC/CEOE, Randolph AFB \\
\hline Charles Kreitler & LBG-Guyton Associates \\
\hline Larry Land & HDR Engineering \\
\hline Robert Mace & Texas Water Development Board \\
\hline Scott Painter & Southwest Research Institute, CNWRA \\
\hline Alvin Schultz & San Antonio Water System Consultant \\
\hline John Waugh & San Antonio Water System \\
\hline Stephen Worthington & Worthington Groundwater \\
\hline
\end{tabular}

\begin{tabular}{|l|l|}
\hline \multicolumn{1}{|c|}{ GWMAP staff } & \multicolumn{1}{c|}{ Affiliation } \\
\hline John Hoyt & Edwards Aquifer Authority \\
\hline Steven Johnson & Edwards Aquifer Authority \\
\hline Ned Troshanov & Edwards Aquifer Authority \\
\hline
\end{tabular}

disagreement within the GWMAP were discussed at the meetings as the stages of model construction and calibration were completed.

\section{Purpose and Scope}

This report describes (1) the hydrogeology of the Edwards aquifer and the conceptual model upon which the Edwards aquifer model is based, (2) the construction and calibration of the Edwards aquifer model, (3) the results of the Edwards aquifer model simulations, (4) the results of sensitivity analysis for the steady-state and transient simulations, (5) model limitations, and (6) needed data and future work. In addition, the results of comparisons between hydraulic heads and springflows for selected observation wells and springs simulated by the Edwards aquifer model and those simulated by a previous numerical ground-water-flow model of the San Antonio segment of the aquifer, termed GWSIM, are presented and discussed. The Edwards aquifer area includes both the San Antonio and Barton Springs segments of the aquifer and all or parts of 11 counties in south-central Texas (fig. 1). The area of active model cells is defined on the north by the northern limit of contiguous outcropping Edwards rocks (updip boundary of the recharge zone) and on the south by the 10,000-mg/L dissolved solids concentration line (downdip boundary of the freshwater/saline-water transition zone [the zone of brackish water between the 1,000- and 10,000-mg/L lines of dissolved solids concentration]) (A.L. Schultz, consultant, written commun., 2000). Thus, the active model area includes the transition zone (fig. 2). The Edwards aquifer model was calibrated for steady-state (1939-46) and transient (1947-2000) conditions.

Although the Barton Springs segment of the aquifer is included in the Edwards aquifer model, calibration procedures were not conducted for the northern part of the segment (Travis County). A numerical finite-difference ground-water-flow model was recently completed for the Barton Springs segment (Scanlon and others, 2002), and a duplication of that work was not considered necessary. Calibration procedures were conducted in the southern part of the Barton Springs segment (northern Hays County), however, because the simulated hydraulic heads and flows in that area influenced the location of the ground-water divide near Kyle and the simulated hydraulic heads and flows in the adjoining part of the San Antonio segment of the aquifer. In addition to the limited calibration for the Barton Springs segment of the Edwards aquifer, Hueco and Las Moras Springs were not used as calibration targets in the Edwards aquifer model. Hueco Springs was not simulated in the model because of uncertainty regarding the source of the water discharging from the springs. Las Moras Springs was simulated in the model but not used as a calibration target also because of uncertainty regarding the source of the water discharging from the springs. The water discharging from Hueco Springs might include an unknown percentage derived from the Trinity aquifer. The water discharging from Las Moras Springs includes an unknown percentage derived from ground-water flow toward the springs from west of the western model boundary. 


\section{EXPLANATION}

Active ground-water-model area

Hydrogeologic zones

Recharge zone (outcrop) (modified

from Puente, 1978

Confined zone

Freshwater zone

Freshwater/saline-water transition zone Inactive ground-water-model area Catchment area updip of recharge zone;
saline zone downdip of transition zone

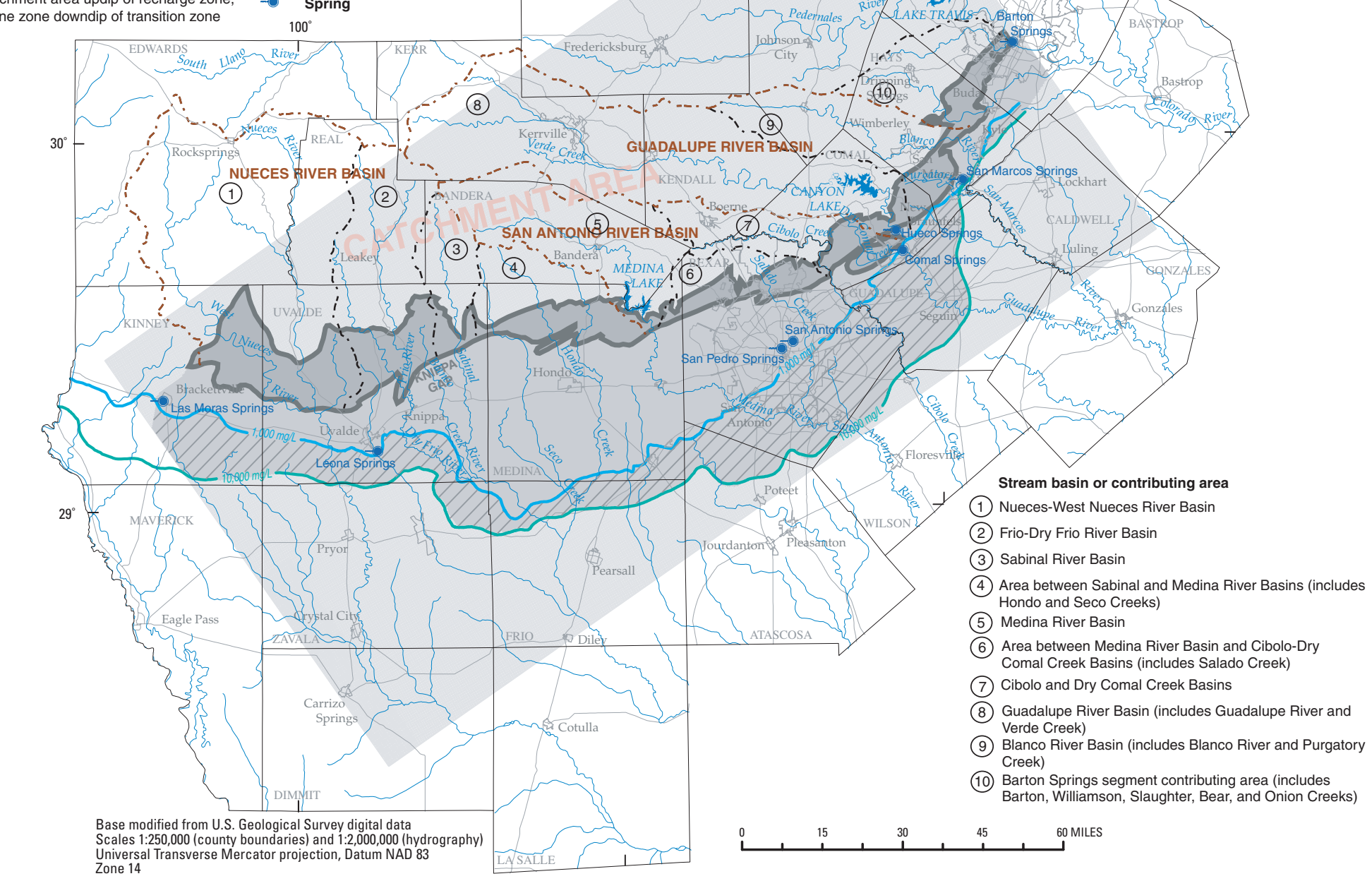

Major river basin boundary

-- Stream basin or contributing area boundary Line of 1,000 milligrams per liter dissolved solids conce written commun., 2000)

_L Line of 10,000 milligrams per liter dissolved solids concentration (A.L. Schultz, consultant, written commu 2000)

Figure 2. Hydrogeologic zones and catchment area (upper parts of stream basins that contribute recharge) of the Edwards aquifer, San Antonio region, Texas. 


\section{Conceptualization and Simulation of the Edwards Aquifer, San Antonio Region, Texas}

\section{Physiography and Climate}

The Edwards aquifer model area spans the margins of two physiographic provinces (fig. 1), each of which is characterized by different physiographic, hydrologic, and geologic features. From northwest to southeast, these provinces are the Edwards Plateau and the Gulf Coastal Plain. The Balcones fault zone occupies southeastern margins of the Edwards Plateau and northwestern margins of the Gulf Coastal Plain. The Balcones escarpment, which separates the Edwards Plateau from the Gulf Coastal Plain, lies within the Balcones fault zone.

The Edwards Plateau is a resistant, carbonate-rock upland veneered with loose, thin soils atop nearly flat-lying limestone and dolostone of Early Cretaceous age. The eastern and southern margins of the Edwards Plateau are topographically rugged where high-velocity headwaters have cut narrow, steep-walled canyons into the carbonate terrain. The area is known locally as the Texas Hill Country. The Trinity aquifer is the principal aquifer in the Hill Country.

The Gulf Coastal Plain is underlain by gulfward-dipping wedges of sands and clays of Tertiary age, except within the Balcones fault zone where shale, limestone, and clay of Cretaceous age are exposed. The surface of the Coastal Plain is dominated by rolling-to-virtually-flat prairie land.

The Balcones fault zone is characterized by a system of faults trending northeastward in the northern part and becoming more strongly en echelon as the fault zone curves westward, defining the northwestern margin of the Gulf Coastal Plain. The Edwards aquifer is the principal aquifer in the Balcones fault zone. The Balcones escarpment, along which the elevated Hill Country is juxtaposed against the low-lying Gulf Coastal Plain, was formed during the Tertiary period by faulting along the Balcones fault zone. Land-surface altitudes typically increase abruptly at the escarpment, rising from about 100 feet (ft) to several hundred feet above the adjacent Coastal Plain. Caves and sinkholes are common where Cretaceous limestone is exposed in elevated areas north of the Balcones escarpment, such as in northern Bexar, northwestern Comal, and Hays Counties (Maclay, 1995).

Periods of excessive rainfall followed by extended droughts are characteristic of the area and cause major hydrologic effects. The frequency and length of these periods are irregular. At least one serious drought has occurred in southcentral Texas during each decade of the 20th century (Larkin and Bomar, 1983). The most severe drought occurred during 1950-56, when rainfall at San Antonio was less than the 30year (1961-90) normal (31 inches per year [in/yr]) during each year of this 7-year span. During 5 of those years, rainfall was two-thirds or less of the 30-year normal (San Antonio Water System, 2000). In summer 1956, after several years of slowly declining flow, Comal Springs ceased flowing. However, during late 1956 and 1957, major drought-breaking storms recharged the aquifer, and since then, Comal Springs has flowed continuously. During the 1970s and 1990s, the region generally had greater than the 30-year normal rainfall; however, dry years (such as 1975 and 1996) periodically resulted in declines of water levels in the Edwards aquifer and belowaverage springflow. Annual rainfall at San Antonio exceeded 40 inches (in.) for 1957, 1973, 1985-86, 1991-92, 1994, and 1998 (San Antonio Water System, 2000).

\section{Previous Investigations and Research}

Many investigations of the Edwards aquifer have been conducted in the San Antonio region of central Texas. Bibliographies of the extensive literature pertaining to the Edwards aquifer have been compiled by the USGS (Menard, 1995) and the Edwards Aquifer Authority (Esquilin, 2004). Early work included that by Sayre and Bennett (1942), who presented the concept of northeastward ground-water flow in the Edwards aquifer. William F. Guyton and Associates (1955) and Puente (1978) investigated methods for estimating recharge to the Edwards aquifer. The regional synthesis of the stratigraphy of the Edwards Group in central Texas by Rose (1972) provided a stratigraphic framework for subsequent hydrologic investigations. Extensive data on water levels, surface geology, and water quality were collected as part of general hydrologic studies of the Edwards aquifer by Petitt and George (1956) and Garza (1962, 1966); and also as part of evaluations of the ground-water resources of various counties in the San Antonio region by George (1952), Arnow (1963), Holt (1959), Bennett and Sayre (1962), Welder and Reeves (1962), and DeCook (1963).

Subsequent investigations included reconnaissance, data collection, and assimilation of knowledge about the hydrogeology (Maclay and others, 1981; Small and Maclay, 1982) and hydrochemistry (Pearson and Rettman, 1976; Maclay, Rettman, and Small, 1980) of the Edwards aquifer. Maclay and Small (1983, 1984) and Small (1986) analyzed geologic, hydrologic, and hydrochemical data and developed concepts regarding the nature of flow in the Edwards aquifer and the internal and external boundary conditions of the aquifer. Ogden, Quick, Rothermel, and Lundsford (1986) and William F. Guyton and Associates (1979) described the hydrogeology of Comal, San Marcos, and Hueco Springs. Schultz (1992, 1993, 1994) used geophysical logs and water-quality data to define the boundaries of the freshwater/saline-water transition zone.

The three-dimensional distribution of hydraulic conductivity in the San Antonio segment of the Edwards aquifer was assessed by Hovorka and others (1995, 1998), Halihan and others (1999), and Mace and Hovorka (2000). Painter and others (2002) developed a distribution of the hydraulic conductivity of the Edwards aquifer on the basis of aquifer tests and geostatistical methods. Porosity development and distribution and the storage properties of the Edwards aquifer were investigated by Hovorka, Ruppel, and others (1993) and Hovorka, Dutton, and others (1996). Tectonic and hydrologic concepts in the Edwards aquifer were proposed by Maclay (1995), and major flow paths described by Groschen (1996). Mace and Hovorka (1997) and Halihan and others (2000) discuss matrix (Edwards rocks without fractures or conduits), fracture, and conduit permeability 
and ground-water flow in the San Antonio segment of the aquifer. Hovorka and others (2004) and Worthington (2004) characterize fractures and conduits in the Edwards aquifer and suggest locations for major conduits.

The evolution of the Edwards aquifer was described by Abbott (1975) and Woodruff and Abbott (1979). Barker and Ardis (1996) comprehensively summarized the hydrogeologic framework of the Edwards-Trinity aquifer system in westcentral Texas from numerous sources. Geochemical processes and evolution in the Edwards aquifer were investigated by Rye and others (1981), Deike (1990), and Oetting and others (1996). Worthington and others (2002) presented techniques for investigating the extent of karstification in the Edwards aquifer.

A number of numerical ground-water-flow models previously have been constructed for the Edwards aquifer in the San Antonio region. Kuniansky and Holligan (1994) reported on simulations of flow in the Edwards-Trinity aquifer system in west-central Texas. Klemt and others (1979) developed a numerical ground-water-flow model (known as the GWSIM model) for the San Antonio segment of the Edwards aquifer that was used to simulate several ground-water-withdrawal and climatic scenarios from 1972 through 2049. Thorkildsen and McElhaney (1992) reevaluated this model and refined the simulation of water levels and springflows in the San Antonio region. The GWSIM model has been used extensively for simulating water-level conditions at the Bexar County index well (monitor well [Texas Water Development Board (TWDB) well 6837203 , pl. 1], commonly referred to as "J-17," in which water-level changes are assumed to reflect Edwards aquifer water-level changes on a regional scale) and springflows at Comal Springs. LBG-Guyton Associates (1996) conducted a study to determine whether the GWSIM model accurately predicts water levels throughout the model area. They concluded that the model can be used to accurately simulate hydrologic conditions in the confined zone of the Edwards aquifer from eastern Uvalde County to western Hays County. However, a very poor correlation, or no correlation, between simulated and measured water levels for 1978 to 1989 was observed for wells located in eastern Hays County, the Knippa gap area and the area west of the Frio River in Uvalde County, and in the recharge zone. Maclay and Land (1988) used a numerical finite-difference model, modified to provide the capability of representing barrier faults, to test concepts of ground-water flow and storage in the San Antonio segment of the Edwards aquifer. Mahin and Campana (1983) developed a discrete-state compartment model for the Edwards aquifer near San Antonio. Model-derived estimates of mean ages of ground water, recharge rates, effective porosities, and storage in the Edwards aquifer were reported by Campana and Mahin (1985). Wanakule and Anaya (1993) developed a lumped-parameter model for the Edwards aquifer in the San Antonio region. Numerical ground-water-flow models for the Barton Springs segment of the Edwards aquifer include those developed by Slade and others (1985), Barrett and Charbeneau (1996), and Scanlon and others (2002). Scanlon and others (2003) evaluated two different equivalent porous media approaches, lumped and distributed parameter, for simulating regional ground-water flow in a karst aquifer (Barton Springs segment of the Edwards aquifer) and evaluated the adequacy of these two approaches.

\section{Acknowledgments}

Material for this report was synthesized from the published results of several agencies, companies, and institutions. Chief contributors of the published data used in this report are the BEG, the former Texas Department of Water Resources now separated into the TWDB and the Texas Commission on Environmental Quality, and the USGS. The USGS and the BEG are indebted also to the EAA and the San Antonio Water System (SAWS) for their assistance with the acquisition of model input data. Bridget Scanlon, BEG, provided input data for the Barton Springs segment of the aquifer, which was incorporated into the Edwards aquifer model. The authors also are indebted to the members of the Ground-Water-Modeling Advisory Panel for their contributions to the conceptualization of the aquifer system and the development of the Edwards aquifer model.

\section{Conceptualization of the Edwards Aquifer}

The conceptualization of the Edwards aquifer includes a description of the geologic and hydrogeologic setting within which the aquifer functions. Paleogeographic and structural features (fig. 3) and major depositional provinces (figs. 1, 3) have influenced the distribution and hydrologic characteristics of the Cretaceous rocks composing the Edwards aquifer and underlying Trinity aquifer in south-central Texas. A number of tectonic and diagenetic processes are responsible for the fractures and solution cavities that influence the distribution of hydraulic properties and thus the nature of ground-water flow in the Edwards aquifer.

The conceptualization presented, which is the basis for the Edwards aquifer model of this report, emphasizes conduit development and conduit flow. Although, as will be described, there is evidence to support the conduit-flow conceptualization, its acceptance among GWMAP members is not universal, and the degree to which conduits pervade the Edwards aquifer and influence ground-water flow remains controversial. An alternate conceptualization, which can be called the diffuse-flow conceptualization, reflects the hypothesis that, although conduits likely are present, flow in the aquifer predominately is through a network of small fractures and openings sufficiently numerous that the aquifer can be considered a porous-media continuum at the regional scale. Which is the more realistic conceptualization-in other words, whether conduit flow or diffuse flow predominates at the regional scale-is an open question. Development of the Edwards aquifer model incorporating the conduit-flow conceptualization thus can be considered a test of one of two reasonable conceptualizations. 


\section{Conceptualization and Simulation of the Edwards Aquifer, San Antonio Region, Texas}

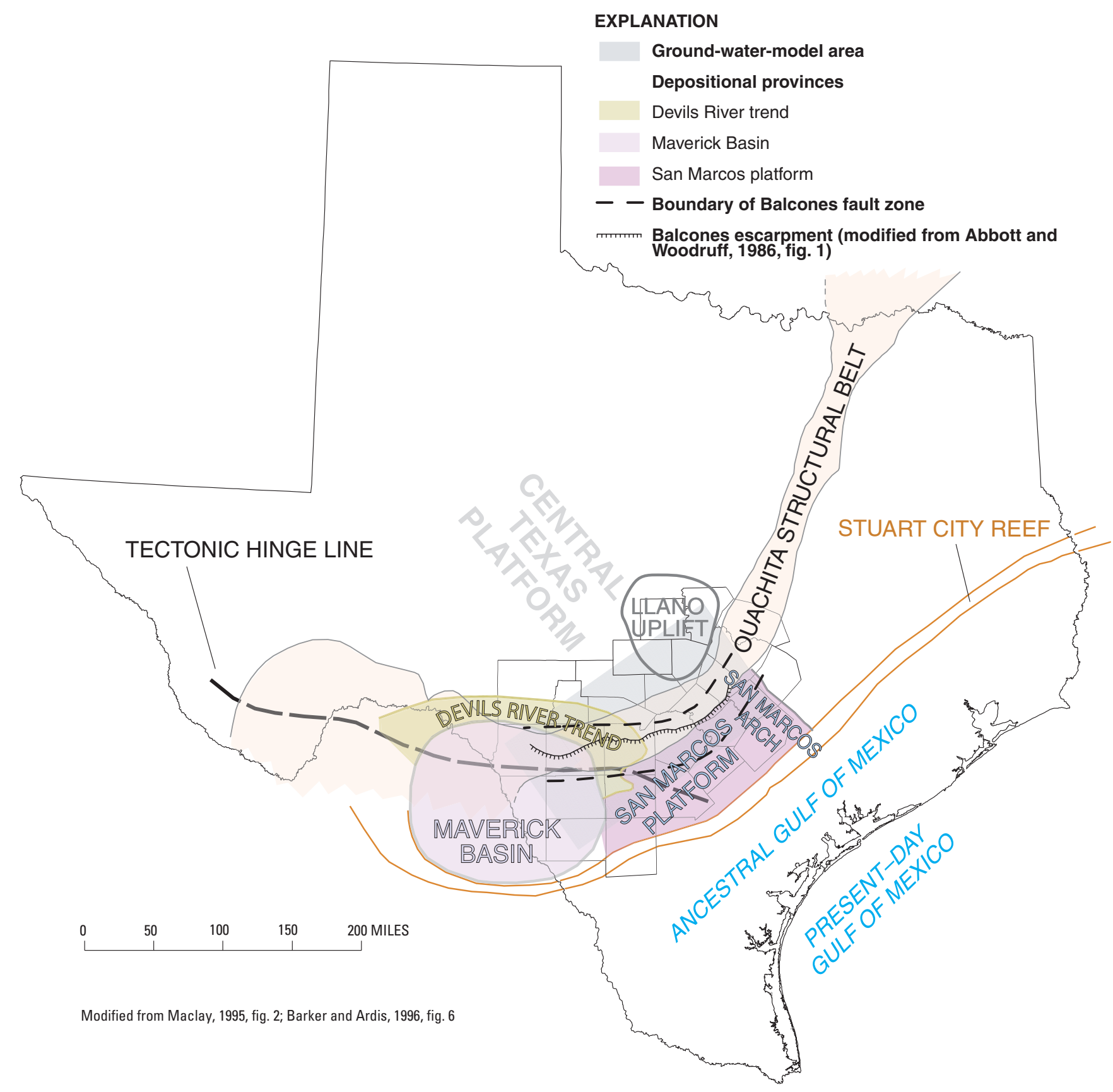

Figure 3. Paleogeographic and structural features in Texas associated with the Edwards aquifer model area.

\section{Geologic Setting}

Sedimentary and crystalline rocks that range in age from Precambrian to Holocene underlie south-central Texas. The Cretaceous rocks include shallow-water facies, which consist of sediments deposited on tidal flats and sabkhas and of subtidal carbonate sediments that accumulated on a carbonate platform. Internal depositional cycle boundaries are overlain by rocks consisting of near-shore and shallow-water sediments in topographically higher parts of the platform grading downdip (sea- ward) into subtidal carbonate rocks. As facies migrated in response to sea level variation and sediment aggradation, different depositional facies are superimposed vertically. Four depositional provinces were formed in south-central Texas during Lower Cretaceous time: the central Texas platform on the Edwards Plateau, Maverick Basin, Devils River trend, and San Marcos platform (Maclay, 1995) (fig. 3). Three of these provinces-the Maverick Basin, Devils River trend, and San Marcos platform-occupy most of the present-day areal extent of the Edwards aquifer in the San Antonio region (figs. 1-4). 


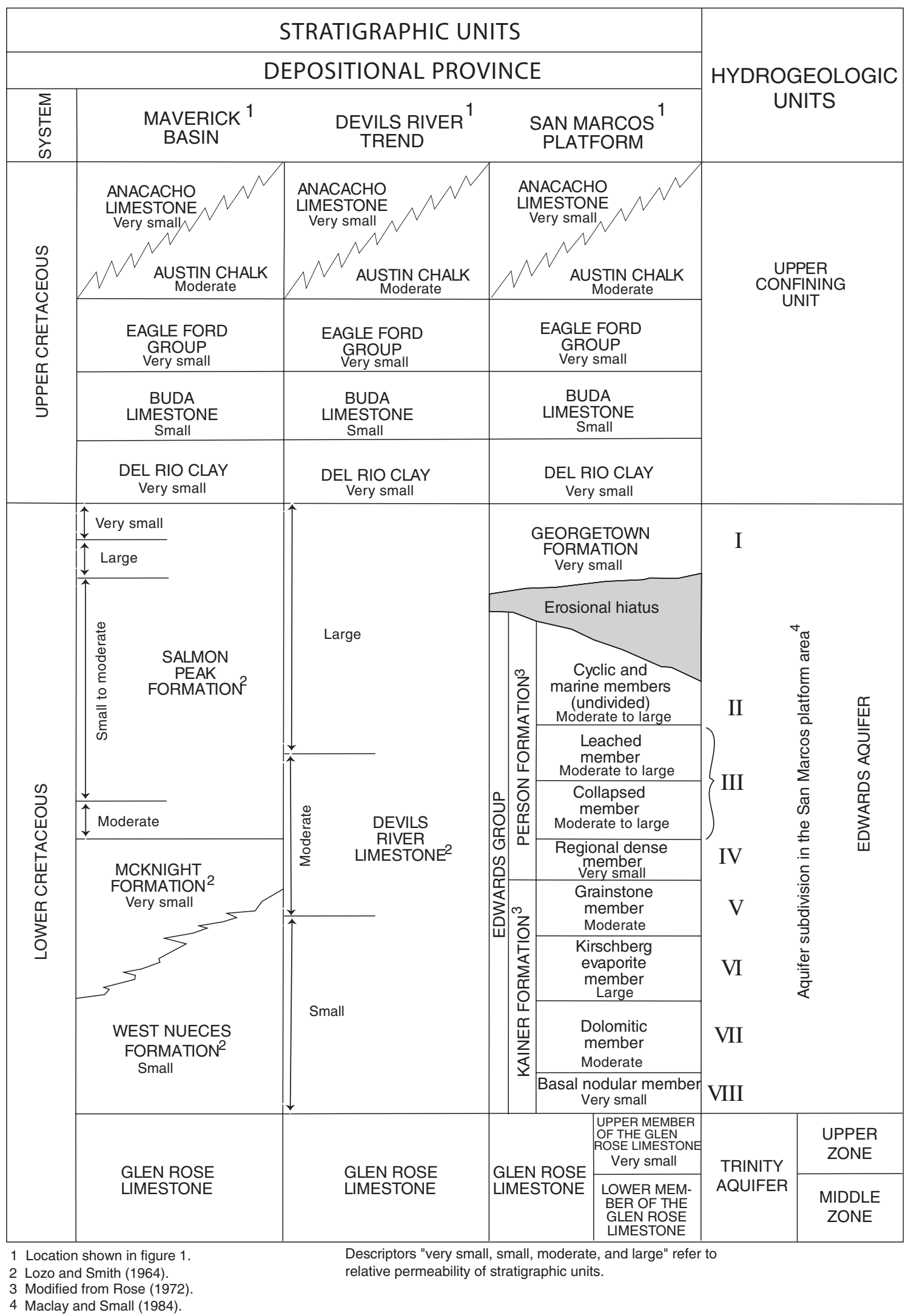

Figure 4. Correlation of Cretaceous stratigraphic units and hydrogeologic units, and relative permeabilities, in the Edwards aquifer model area, San Antonio region, Texas (modified from Maclay, 1995, fig. 11). 
Different depositional facies and different energy conditions associated with carbonate deposition were characteristic in each province.

The Maverick Basin became an area of more rapid subsidence during deposition of Edwards rocks, which resulted in an accumulation of thicker sediments in a predominately subtidal setting. These sediments consist of fossiliferous limestone of the West Nueces Formation; gypsum and anhydrite (now mostly dissolved, leaving breccia) and dark fossiliferous limestone of the McKnight Formation; and fine-grained packstone of the Salmon Peak Formation (Lozo and Smith, 1964; Hovorka and others, 1996). The platform margin rimming the Maverick Basin is known as the Devils River trend. The platform margin is distinguished by stacked, high-energy facies including grainstone, packstone, and rudist patch reefs and associated facies. The San Marcos platform was a region of less subsidence relative to the other regions where the depositional environment varied through space and time from open marine to arid, hot, supratidal flats (Rose, 1972). Dolomite and dolomitic limestone are more abundant on the San Marcos platform than in other regions. The dominant carbonate textures are massive and burrowed packstone and grainstone; collapse breccia, microscale and macroscale structures, calcitized evaporite, and rudist-reef detritus also are identified (Rose, 1972; Hovorka and others, 1996). The San Marcos platform facies of the Edwards Group have been divided into the Kainer and Person Formations (Rose, 1972). The end of the time of formation of the Edwards Group (during Washitan stage) is marked by a period of subaerial erosion and karstification (Rose, 1972). The Edwards Group was buried by several thousand feet of predominantly deep-water, marine-shelf sediments deposited during marine transgression that characterized the later Cretaceous globally.

Igneous rock, mainly basalt, was implanted into older sediments as plugs, dikes, and sills and locally formed volcanoes rimmed by atolls. The volcanic activity was concentrated in Uvalde County contemporaneously with deposition of Anacacho Limestone and Austin Chalk. The basalt commonly is altered to serpentine, particularly in Uvalde County. Volcanic ash and bentonite, commonly from more distant intermediate composition sources, also are abundant in the Upper Cretaceous rock sequence (Hovorka, 1998).

The Edwards aquifer is part of an aquifer system developed in thick and regionally extensive Lower Cretaceous carbonates that underlie large areas of Texas. Stratigraphically complex facies of the Lower Cretaceous, including sandstones, karstic limestones and dolomites, low-permeability calcareous marl, and evaporite units, host the Trinity aquifer. The upper part of the Trinity aquifer, the Glen Rose Limestone, is overlain by limestone, dolomite, and altered evaporite of the Edwards aquifer. The stratigraphically equivalent units that compose the Edwards aquifer are the Kainer and Person Formations (Edwards Group) and overlying Georgetown Formation in the San Marcos platform (Rose, 1972); the Devils River Limestone in the Devils River trend; and the West Nueces, McKnight, and Salmon Peak Formations of Lozo and Smith (1964) in the Maverick Basin (fig. 4). The Edwards aquifer is overlain by the
Upper Cretaceous Del Rio Clay, a thick, regionally distinctive shale that defines the top of the Edwards aquifer. Overlying the Del Rio Clay are, from oldest to youngest, the Upper Cretaceous Buda Limestone, Eagle Ford Group (dominantly shale), Austin Chalk, and Anacacho Limestone.

\section{Hydrogeologic Setting}

The hydrogeologic setting describes the hydrostratigraphy of the Edwards aquifer. The structural and hydrologic features and hydraulic properties that influence ground-water flow in the aquifer also are described.

\section{Hydrostratigraphy}

The Cretaceous strata of south-central Texas regionally include two aquifers, the Edwards aquifer in the Balcones fault zone and the Trinity aquifer in the Hill Country. The correlation chart (fig. 4) summarizes the relation between stratigraphic and hydrogeologic units. This chart combines chronostratigraphic and lithostratigraphic nomenclature with aquifer and confiningunit terminology (Lozo and Smith, 1964; Rose, 1972; Maclay and Small, 1984). The Trinity aquifer in the Hill Country is composed of sediments of the Trinity Group and is divided into lower (not shown in fig. 4), middle, and upper zones, on the basis of hydraulic characteristics of the sediments (Barker and Ardis, 1996; Mace and others, 2000). The upper zone of the Trinity aquifer generally has lower hydraulic conductivity than the Edwards aquifer and, because of shaley interbeds, has a much lower vertical than horizontal hydraulic conductivity (Mace and others, 2000). Conventionally, the lower boundary of the Edwards aquifer is defined as the top of the Glen Rose Limestone (fig. 4).

The degree of hydraulic connection between the Trinity and Edwards aquifers might be limited in many areas by the relatively small hydraulic conductivities of the contiguous units (fig. 4). Evidence of low vertical hydraulic conductivity includes (1) numerous springs and seeps that discharge at the Edwards aquifer-Trinity aquifer boundary in the outcrop and (2) an increase in salinity in the subsurface below the Edwards aquifer-Trinity aquifer boundary apparent on resistivity logs (Hovorka and others, 1996). Cross-formational interconnection across the boundary between the two aquifers regionally is probable, however. Both units are karstic limestones, and large caves that cross the contact are interpreted as evidence that cross-formational flow occurs through karst systems in at least parts of the San Antonio segment of the Edwards aquifer (Veni, 1988; Vauter, 1992). Also, the results from a numerical groundwater-flow model for the Trinity aquifer (Mace and others, 2000) indicated that appreciable cross-formational flow occurs from the Trinity aquifer into the Edwards aquifer in the San Antonio segment.

The carbonates in the Edwards aquifer are laterally and vertically heterogeneous. Maclay and Small (1976, table 1) defined eight "hydrostratigraphic" units within the Kainer, 
Person, and Georgetown Formations that compose the Edwards aquifer in the San Marcos platform of the Balcones fault zone (fig. 4). Highly permeable intervals are variably distributed throughout units II, III, and VI, with the most permeable parts of these units in honeycombed rock (Maclay, 1995). Groschen (1996) indicated that units III, VI, and VII transmit most of the ground water within the San Antonio region. However, highly permeable dissolution features have been observed in all of the hydrostratigraphic units. The Edwards aquifer contains carbonates that have numerous intervals of intercrystalline high porosity, as well as petrophysical properties that make the carbonates subject to development of karst conduits (Hovorka and others, 1998). In the San Antonio segment of the aquifer, interaction between lithologies and structure was observed to influence distribution of karst conduits (Hovorka and others, 1998).

The Georgetown Formation consists of stratigraphically distinct limestone that overlies and is generally of lower porosity and hydraulic conductivity than the Edwards Group. The contact is at least locally unconformable, with development of pre-Georgetown karst (Rose, 1972). The Georgetown Formation is commonly included within the Edwards aquifer because (1) there is no barrier to hydrologic connection between the Edwards Group and Georgetown Formation, (2) karst features are at least locally developed in the Georgetown Formation, and (3) it is difficult to separate the carbonates of the Edwards Group consistently from those of the Georgetown Formation using the gamma-ray logs or drillers' reports commonly available for the subsurface (Scanlon and others, 2002).

The thick and regionally extensive shale of the Del Rio Clay directly overlies and confines the Edwards aquifer. The high clay content and plasticity of the Del Rio suggest that it generally functions as an effective barrier to vertical flow (Scanlon and others, 2002). The thick shales and marls of the overlying Eagle Ford Group additionally confine the Edwards aquifer.

The Edwards aquifer is unconfined adjacent to and in the outcrop (recharge zone) where recharge occurs (fig. 2). The Edwards aquifer is confined in downdip parts of the Balcones fault zone by overlying hydrogeologic units of small to very small permeability (Del Rio Clay, Buda Limestone, and Eagle Ford Group) (figs. 2, 4). The confined part of the aquifer includes, on its downdip (gulfward) margin, the freshwater/ saline-water transition zone (fig. 2). The concentration of dissolved solids on the freshwater side of the transition zone ranges from about 250 to $300 \mathrm{mg} / \mathrm{L}$ (Pavlicek and others, 1987). The concentration of dissolved solids downdip of the transition zone rapidly increases in a gulfward direction to more than 250,000 $\mathrm{mg} / \mathrm{L}$ (Maclay and Land, 1988). The locations of lines of equal concentration of dissolved solids ranging from 1,000 to 100,000 $\mathrm{mg} / \mathrm{L}$ for the San Antonio segment of the Edwards aquifer have been mapped (Schultz, 1992, 1993, 1994; A.L. Schultz, consultant, written commun., 2000).

\section{Structural Features}

Three major structural elements dominate the geologic structure of south-central Texas; the Llano uplift (and its subsurface extension, the San Marcos arch), the Ouachita structural belt, and the Balcones fault zone (figs. 1, 3). The Llano uplift is a long-lived regional positive element that has pre-Cambrian metamorphic and plutonic rocks exposed in its core. The San Marcos arch is a broad anticlinal extension of the Llano uplift with a southeast-plunging axis through central Blanco and southwest Hays Counties (Ashworth, 1983). The Ouachita structural belt is a late Paleozoic compressional tectonic province which later subsided and was buried by Mesozoic and Cenozoic rocks as the Gulf of Mexico opened and subsided (Flawn, 1964, p. 271-274).

The Balcones fault zone is a system of high-angle normal faults with net displacement toward the Gulf of Mexico and constitutes the principal structural deformation affecting Edwards aquifer development. Most of the uplift of the Edwards Plateau along the Balcones fault zone took place in the Miocene (Ewing, 1991). This deformation occurred along a sinuous trend extending from north of Austin through San Antonio and west past Bracketville. The underlying Ouachita structural belt provided a pivot between the uplifting of the Edwards Plateau and the subsidence of the adjacent Gulf Coastal Plain. The gentle southeastward dip of Cretaceous strata in the Edwards Plateau and Hill Country is interrupted across the Balcones fault zone by a system of en echelon faults that generally strike northeastward (Maclay, 1995). The faulting occurred along the subsurface axis of the Ouachita structural belt as a result of extensional forces created by the subsidence of basin sediments in the Gulf of Mexico (Mace and others, 2000). The vertical displacements of these faults vary along the strike of each individual fault. Faults of the Balcones fault zone are shown in figure 5.

Maps of the top (in the subcrop), base, and thickness of the Edwards aquifer and faults were created by interpretation of six datasets. The first dataset comprised data from subsurface mapping of the top of the Edwards aquifer in the San Antonio segment of the aquifer (Collins and Hovorka, 1997), on the basis of log analysis and outcrop mapping by the BEG (Collins, 2000; E.W. Collins, University of Texas, Bureau of Economic Geology, written commun., 2002). The second dataset comprised data from subsurface mapping of the top of the Edwards aquifer and the top of the Trinity aquifer in the unconfined part of the San Antonio segment of the Edwards aquifer and in the Barton Springs segment of the aquifer. Data for the Barton Springs segment were based on unpublished log analysis and mapping of N.L. Hauwert (Barton Springs/Edwards Aquifer Conservation District, written commun., 2000). The third dataset included data from hydrogeologic mapping of Travis, Hays, Comal, and Bexar Counties (Small and Hanson, 1994; Hanson and Small, 1995; Stein and Ozuna, 1995; Small and others, 1996). The fourth dataset comprised interpretive structural data of A.L. Schulz (consultant, written commun., 2002) for areas in northern San Antonio and Uvalde County, based on reinterpretation of previous structural maps using mostly log data. The fifth and 


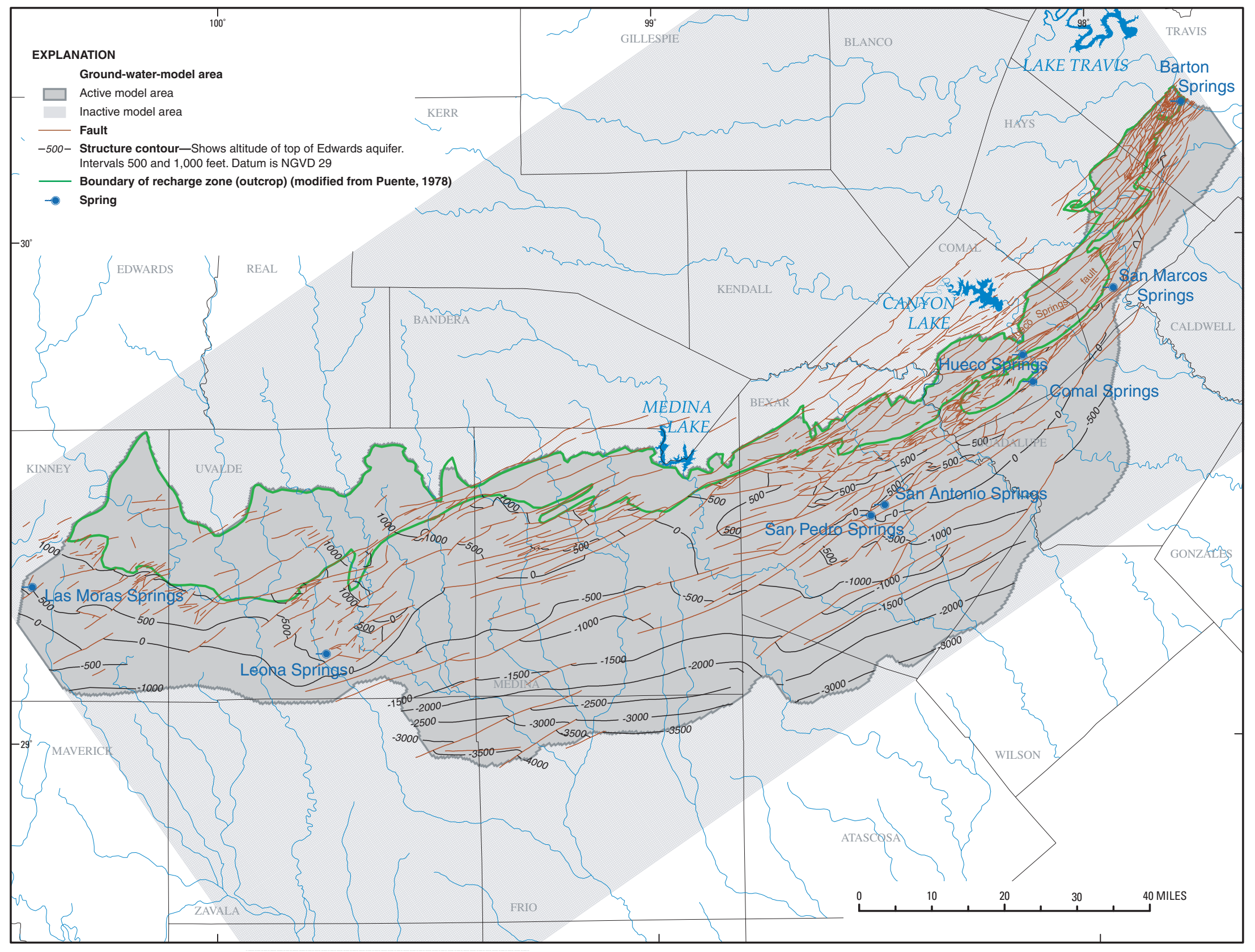

Figure 5. Altitude of the top of the Edwards aquifer (in the subcrop) and fault locations, San Antonio region, Texas (modified from Collins and Hovorka, 1997). 
sixth datasets comprised data interpreted from wireline logs (Edwards Aquifer Authority, unpub. data, 2002) and thickness data for the Edwards aquifer from Hovorka and others (1995), respectively. The base of the Edwards aquifer was defined as the stratigraphic contact between the Edwards Group and the Glen Rose Limestone as marked by a regionally correlatable high gamma-ray log signature. The top of the Edwards aquifer was mapped at the contact between the Georgetown Formation and Del Rio Clay, which is a prominent regional marker on wireline logs.

Geographic information system (GIS) software was used to aggregate and identify differences in interpretation among the aquifer top, base, and thickness, and fault data described above. Major discrepancies were resolved by reexamination of log data. Many small variations in structural interpretations were noted but could not be uniquely resolved. Where various structural interpretations could not be integrated, the interpretation of Collins and Hovorka (1997) was used because it could be unified most consistently throughout the entire region.

Because of the structural complexity and the fewer penetrations of the base of the aquifer in the confined section as compared to penetrations of the top, the base of the aquifer in the confined zone was created by gridding both the aquifer top and the thickness and subtracting the thickness from the top. The dip and other three-dimensional complexities of faults cutting the Edwards aquifer were not expressed in the creation of the structural dataset.

The altitude of the top and thickness of the Edwards aquifer in the San Antonio region are shown in figures 5 and 6 , respectively. Altitudes mapped are in feet with respect to NGVD 29. The altitude of the top of the aquifer ranges from about 1,000 ft above NGVD 29 near the recharge zone in the western part of the active model area to about 4,000 ft below NGVD 29 near the downdip limit of the active model area in Frio County (fig. 5). The aquifer thickness ranges from about $450 \mathrm{ft}$ near the recharge zone in Bexar, Comal, and Hays Counties to about 1,100 ft in Kinney County (fig. 6).

\section{Karst Hydrogeology}

A karst aquifer is an aquifer developed in soluble rocks with a permeability structure dominated by interconnected conduits dissolved from the host rock that facilitate the circulation of fluid in the downgradient direction wherein the permeability structure evolved as a consequence of dissolution by the fluid (Huntoon, 1995). An integrated aquifer-wide network of solutionally enlarged conduits with rapid flow characterizes karst aquifers (Huntoon, 1995; Worthington, 1999). These networks form tributary systems that discharge at springs (Worthington, 2004). Karst aquifers commonly are conceptualized as dualflow systems that comprise a continuum-flow system with Darcian flow comparable to porous media and a discrete conduit network frequently with turbulent flow conditions (Birk and others, 2003). Conduits having a wide range of spatial and temporal scales are common in karst aquifers.
In many carbonate aquifers, the bulk of the water is transmitted, for unsaturated flow conditions (caves), by turbulent flow in solutionally enlarged conduits (Gale, 1984). Aquifer anisotropy and heterogeneity, inherent in carbonate aquifer systems, can affect both the direction and velocity of ground-water flow. Fluid flow in karst carbonate aquifers can be highly variable and difficult to measure or predict.

Tracer testing provides evidence for extensive conduits in carbonate aquifers. Worthington, Davies, and Ford (2000) reported an average velocity along conduits of 5,577 feet per day $(\mathrm{ft} / \mathrm{d})$, on the basis of a representative set of 2,877 tracer tests. The mean distance traced in this dataset was 3.9 miles (mi), and 124 traces were over distances of at least $12.4 \mathrm{mi}$. Aquifer tests also might be used to assess karstification in a limestone aquifer (Worthington and Ford, 1997; Worthington, 1999). However, whether the enhanced flow that commonly occurs at certain horizons in a well is only of local scale or whether it is more extensive is uncertain (Worthington, 2004).

\section{Karst Development}

An important development in the theory of karst conduit formation was the investigation of the dissolution kinetics of limestone in a series of laboratory experiments, starting in the 1970s (Berner and Morse, 1974; Plummer and Wigley, 1976). Later investigations included the simulation of the development of conduits by coupling kinetic and equilibrium dissolution with aquifer hydraulics using numerical modeling. Dreybrodt (1996) concluded that the development of conduits was to be expected in all limestone aquifers where there is ready recharge and discharge. Birk and others (2003) described the coupling of a discrete pipe network to MODFLOW, the USGS groundwater-flow model (McDonald and Harbaugh, 1988), to simulate rapid conduit flow. In addition to flow processes, the coupled model accounts for the increase in permeability caused by solutional enlargement of conduits. Worthington (2001) demonstrated favored conduit development in parts of an aquifer deep below the water table, where flow paths are longer than about $1.9 \mathrm{mi}$, rather than in shallower parts.

The San Antonio segment of the Edwards aquifer is developed in 450- to 900-ft-thick Lower Cretaceous platformal carbonates (Hovorka and others, 1996). Original sediments composed of aragonite, calcite, dolomite, and gypsum have been extensively replaced by calcite within the aquifer and form a highly porous and strongly heterogeneous limestone rock. Hydrologically important heterogeneities within this rock include variable rock fabrics and structural features. Variable rock fabrics contain lateral and vertical variation in depositional-facies character in response to Cretaceous depositional processes, which has resulted in beds of varying solubility and mechanical properties. These variable rock fabrics are stacked to form regionally extensive stratigraphic intervals having distinctive rock properties that are mapped as formations and hydrostratigraphic zones of the Edwards aquifer. Karst was developed contemporaneously with sedimentation at the top of and possibly within the Edwards Group on the San Marcos 


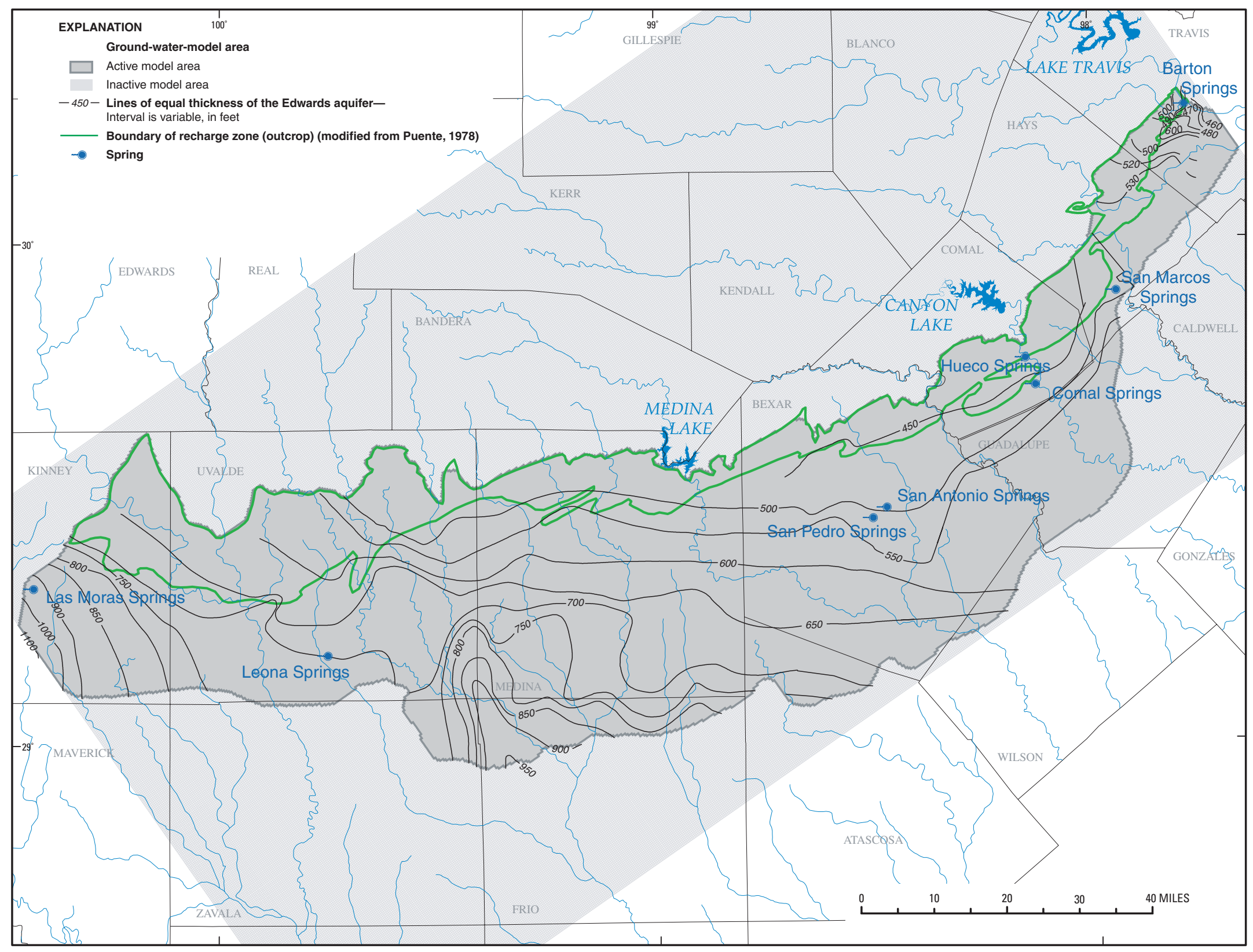

Figure 6. Thickness of the Edwards aquifer, San Antonio region, Texas (modified from Hovorka and others, 1998) 
platform, and this karst has created a zone of high permeability of unknown continuity at the top of the Edwards aquifer (Maclay 1995; Hovorka and others, 1998). Regional doming and intrusion of Upper Cretaceous igneous bodies through the present-day Edwards aquifer in the Uvalde County area created additional complexity in this part of the aquifer (Hovorka and others, 2004, fig. 1b). Extensional down-to-the-coast faulting forming the Balcones fault zone superseded earlier-formed heterogeneity. Faulting had a critical role in aquifer evolution because it (1) increased permeability by forming fracture networks and (2) greatly increased hydraulic gradient by uplift of the base of the present-day Edwards aquifer to altitudes greater than 1,500 ft above NGVD 29 in the western part of the aquifer, whereas at the downdip limit of the aquifer, the top of the aquifer is about 4,000 ft below NGVD 29 at its deepest point (fig. 5).

Introduction of freshwater into this heterogeneous and highly permeable carbonate rock created an extensive aquifer, which in turn modified the rock properties by the selfreinforcing mechanisms of preferential flow through larger aperture pores and preferential dissolution in zones of higher flow, which formed large, interconnected conduits (for details of this process, see Palmer [1991]). Several important factors are recognized that control karstic dissolution. One factor is ground-water piracy that caused diversion of recharge from the west to discharge points at springs in the east and north. Woodruff and Abbott (1986) noted the asymmetry of surfacewater drainage gradients, showing capture toward the east as surface streams with eastward flow directions, such as the Colorado, Llano, Pedernales, Blanco, and Guadalupe Rivers, captured the headwaters of southward-draining streams, such as the West Nueces, Frio, Sabinal, and Medina Rivers (Hovorka and others, 2004, fig. 3). Greater downward incision of eastward-flowing streams created potentiometric lows in the Edwards aquifer flow system. Capture of local discharge and diversion of flow along relatively higher-permeability heterogeneities in the subsurface toward these low points has resulted in integration of the entire aquifer to discharge at the highvolume Comal, San Marcos, and Barton Springs.

The other factor influencing karst development is dissolution at depth. Undersaturation with respect to dolomite is modeled as a result of mixing low-salinity calcium bicarbonate waters in the Edwards aquifer with high-salinity calcium sulfate water (Deike, 1990). Petrographic and hydrologic observations provide evidence that mixing-zone dissolution near the interface between freshwater and saline water has created high porosity and high permeability preferentially focused where dolomite has been dissolved (Hovorka and others, 1998). The dedolomitization process is driven by gypsum solution. Other mechanisms are known to produce deep karst by upwelling high-sulfide water (Palmer, 1991; Klimchouk and others, 2000).

High permeability is developed in the confined part of the Edwards aquifer at depths of as much as 4,000 ft below NGVD 29, as well as in the unconfined zone (Hovorka and others, 2004). The volume, size, shape, and distribution of macroscopic solution features reflect the complex geologic history of the rocks that compose the aquifer. Solution features can be related to stratigraphic, structural, and fabric influences on preferential solution of some areas of the rocks. Paleokarst, near-surface effects, and collapse because of dissolution of underlying horizons also are recognized in outcrops as factors that influence the amount and distribution of solution features. Stratigraphic control on karst formation is evident where caves, soft porous carbonate, and terra rossa infills occur preferentially at one horizon. Stratigraphic controls on dissolution include (1) preferential dissolution of dolomite, (2) dissolution focusing in breccia zones, and possibly, (3) preferential dissolution of calcitized evaporite zones that contain abundant, connected vugs (Hovorka and others, 1998). In almost all outcrops, caverns have developed preferentially in former dolostones. Structural control on karst development is very important. Hovorka and others (1998) described solution enlargement along fractures and solution enlargement producing caves along faults. Preferential development of caves in highly fractured zones adjacent to faults and in dolomitized intervals was observed in the outcrop area. The relation between lineaments and fractures in the Edwards aquifer, transmissivity, and cave orientation was studied by Wermund and others (1978) and Alexander (1990). Fabric control of dissolution is illustrated where vugs initially created by alteration and dissolution of gypsum or dissolution of large rudist fossils have been further enlarged by dissolution of matrix carbonate (Hovorka and others, 1998).

Paleokarst has long been recognized as an important feature in the evolution of Edwards aquifer permeability (Cronin, 1932; Fisher and Rodda, 1969; Rose, 1972; Abbott, 1975; Woodruff and Abbott, 1986). Paleokarst features can be related to episodes of subaerial exposure during accumulation of Edwards rocks, to relative sea-level fall and exposure at the end of deposition of Edwards rocks, and to phases of aquifer development. Another variable influencing the development of karst is the hydrologic setting. Only paleokarst associated with periods of Cretaceous exposure is identified downdip of the freshwater/saline-water interface. Enhancement of matrix permeability is seen regionally near the freshwater/saline-water interface (Hovorka and others, 1998). Solution features are abundant in the outcrop area. Vugs within the outcrop result from solution features that occurred within both the saturated and unsaturated zones of the aquifer. Fractures, solutionenlarged fractures, and caves make up 1 to 3 percent of the outcrop area in the San Antonio segment of the Edwards aquifer (Hovorka and others, 1998). Hovorka and others (2004, figs. $4 \mathrm{~b}, \mathrm{c}$ ) illustrate typical cave and fracture development in the outcrop area.

\section{KarstFeatures}

Evidence of the karstic nature of the Edwards aquifer is abundant and diverse and includes outcrop observations, subsurface data, hydrologic information, tracer test results, and biologic data. In the outcrop, karst landforms are characteristic of the Edwards aquifer. Karst landforms include large (as much as $1 \mathrm{mi}$ across, but more typically tens to hundreds of feet 
across) shallow, internally drained depressions (Hovorka and others, 2004, fig. 4a); depressions of holes in creek bottoms; and small, upland features such as sinkholes and solutionenlarged fractures. An inventory in part of the Barton Springs segment of the Edwards aquifer recharge zone south of Austin has identified nearly 1,000 karst features in a 40-square-mile area on the Edwards outcrop (Hovorka and others, 2004). Inspection of representative karst features in the outcrop of the San Antonio segment of the Edwards aquifer indicates that karst-feature density in this segment of the Edwards outcrop is similar to that in the Barton Springs segment, although the density has not been quantified. More than 400 caves have been inventoried in the Edwards aquifer outcrop (Veni, 1988; Elliott and Veni, 1994), and several hundred of them have been mapped and data archived with the Texas Speleological Survey (Hovorka and others, 2004, fig. 4d). Wermund and others (1978) documented the alignment of mapped cave passages with lineaments in both the Edwards Group and Glen Rose Limestone, documenting as well the importance of structural fabrics in focusing dissolution.

Outcrops provide important information about the origins, dimensions, and distribution of caves, solution-enlarged fractures, and solution along bedding planes. Maclay (1995) indicated that fresh fractures in unconfined, freshwater parts of the Edwards aquifer outcrop and shallow subcrop evolved into cavernous openings near the water table. In a study by Hovorka and others (1998), photomosaics were prepared of vertical roadcut outcrops, and the geometry of fractures and solutionenlarged karst features were digitized and quantified in the field and on photographs. In two-dimensional cross section, karst features make up 1 to 5 percent of the area of the outcrop. Solution enlargement preferentially developed where faults and fractures intersect solution-prone beds. Larger features appear to have preferentially developed in brecciated zones near small faults. Vertical conduits, some filled with terra rosa sediments, are observed in some outcrops. These are attributed to an unsaturated stage of karst evolution postdating and superseding features developed under saturated conditions.

Although deep conduits have not been entered by humans, the existence of karst in the deep saturated zone is known from borehole televiewer images of caves and solution-enlarged fractures, cave textures, and sediments recovered in cores, bit drops during well construction, oversize caliper logs, and offscale porosity logs. Hovorka and others (1996) analyzed porosity of the Edwards aquifer using wireline logs. These logs showed appreciable areas of coincidence between very high porosity and enlarged or off-scale caliper, which likely indicates borehole intersection of a cave or solution-enlarged bedding plane or fracture. This evidence of karst is found throughout the Edwards aquifer and is not focused in any particular structural or stratigraphic setting. Maclay and Small (1984) indicated that tubular openings or solution channels (conduits) probably exist in areas of homogeneous, dense, fractured limestone, particularly in the western part of the San Antonio area; these tubular openings are aligned along fractures and are oriented in the direction of ground-water flow.
Evidence of karstic cavernous porosity at depth includes reports by well drillers of caves, indicated by bit drops, in the downdip part of the Edwards aquifer within the transition zone and the occurrence of deposits associated with unsaturated conditions (cave popcorn and travertine) in cores obtained from the confined zone (Maclay and Small, 1984). In Bexar County, live, blind catfish have been netted from the water discharging from flowing wells with depths of about 1,500 ft (Longley, 1981). These wells are at distances of more than $15 \mathrm{mi}$ from the unconfined part of the aquifer. The presence of the catfish at these wells indicates that interconnected cavernous openings exist at great depths in the aquifer. A diverse macrofauna adapted to subterranean conditions, including unique species of blind catfish, have been recovered from Edwards aquifer wells, which demonstrates the existence of adequate habitat to support these species (Longley, 1986). Krejca (2002) used biologic diversity to infer connectivity of Edwards aquifer karst systems.

Hydrologic evidence of the nature of karst in the Edwards aquifer is abundant and growing, although additional analysis is needed to quantify flow through this heterogeneous and dynamic system. The principal evidence of flow through karst is the heterogeneous and rapidly responsive nature of waterlevel variation. Water levels in the aquifer and discharge at springs rise rapidly after rainfall and then decline at a variable rate, showing drainage from rocks characterized by both conduit and matrix permeability (Atkinson, 1977). Wells close together can have different responses to a single recharge pulse (Johnson and others, 2002). Hovorka and others (1998) and Mace and Hovorka (2000) identified eight orders of magnitude variation in hydraulic conductivity and a large degree of heterogeneity among closely spaced wells. About 15 percent of the wells had no measured drawdown during a specific-capacity test, which shows that hydraulic conductivity of the aquifer is higher than can be determined with aquifer tests. The response of springs to rainfall is rapid. The maximum lag between rainfall and peak springflow was 11 days or less at Comal Springs and 9 days or less at San Marcos Springs following an intense storm October 17-19, 1998, centered in Comal County (Tomasko and others, 2001). Similarly, the effects of watering restrictions in San Antonio in August 2000 indicate that spring response is less than 1 day (Worthington, 2004).

Using data from single storms, Worthington (2004) demonstrated two distinct responses in the Edwards aquifer. Peak water levels at Comal and San Marcos Springs and a few wells in the recharge zone were reached within a few days of the October 17-19, 1998, storm, which shows a rapid response. Worthington (2004) concluded that high heads in the conduits that feed the springs produce the peak responses in the springs, with the pressure pulse from the higher water levels in the recharge zone being transmitted quickly to the springs. Most wells, however, attained peak water levels after about 2 months, which demonstrates a much slower response. Worthington (2004, p. 6) proposed that, "these wells are not located on conduits and their response is attenuated by the much lower permeability in the matrix and smaller fractures in the aquifer." 
Mapping of hydraulic conductivity (Hovorka and others, 1998) showed more high values in the deep, confined parts of the aquifer than in the shallow unconfined and semiconfined parts. A similar pattern of porosity increase with depth that cuts across the depositional trends is noted, which supports an interpretation of enhanced dissolution processes by mixing of deep freshwater and saline water. Further interpretation of quantitative outcrop and aquifer-test data by Halihan and others (2000) assessed the connectivity of karst. This assessment modeled the hydraulic conductivity of the matrix, fractures, and conduits using simplified assumptions about the connectivity of the system. They concluded that a hydraulic-conductivity distribution represented by fractures with maximum apertures of about 0.04 in. is reasonable. Although conduits with apertures 10 to 1,000 times larger ( 0.4 to $40 \mathrm{in}$.) are observed in many wells, the assumption that these apertures are continuous in three dimensions produces hydraulic conductivity greater than that of those measured. As a corollary, conduits with apertures in the range of 0.4 to $40 \mathrm{in}$. might be contributing to flows in an undetermined fraction of the wells with no measured drawdown in aquifer tests. Wells in the aquifer with very high yields, possibly related to the presence of conduits, are known; for example, a 30-in.-diameter agricultural well near the downdip extent of freshwater flowed at 40,000 gallons per minute (gal/min) and discharged to the Medina River (Rettman, 1991).

Large-scale channel networks in limestone aquifers characterized by sinking streams and springs can be investigated using tracer tests. However, large well withdrawals in San Antonio and the large scale of the Edwards aquifer make tracer tests difficult to apply and interpret. Tracer testing in the San Antonio segment of the Edwards aquifer has shown rapid flow (velocities of 590 to $2,625 \mathrm{ft} / \mathrm{d}$ over distances of 0.5 to $2.5 \mathrm{mi}$ ) from wells to the nearby high-flow springs (Ogden, Quick, Rothermel, and Lundsford, 1986; Rothermel and others, 1987; Schindel and others, 2002). Rapid transmission of contaminants from several spill sites (Mace and others, 1997; Schindel and others, 2002) also indicates the likelihood that conduit flow systems are in the San Antonio segment of the Edwards aquifer.

Worthington (2004) identified aquifer characteristics that differ between a karst aquifer and an ideal porous medium (that is, homogeneous and isotropic) and compared the Edwards aquifer to these two contrasting aquifer types. Six criteria were identified and applied to the Edwards aquifer: (1) nature of discharge to the surface, (2) shape of the potentiometric surface, (3) downgradient trend in hydraulic gradients, (4) downgradient trend in hydraulic conductivity, (5) scaling effects in hydraulic conductivity, and (6) flow regime. Worthington (2004, p. 16) concluded that, "each of the six criteria provides evidence that flow in the Edwards aquifer is more like an ideal karst aquifer than an ideal porous medium aquifer," thereby supporting the concept that "there is an integrated network of conduits connecting the major sinking streams with the springs."

The natural discharge from the Edwards aquifer to the surface occurs at six major springs (Comal, San Marcos, Leona, San Antonio, San Pedro, in the San Antonio segment, and
Barton Springs in the Barton Springs segment) (fig. 1), all with multiple orifices and occurring on or close to major faults. Multiple orifices are common for springs in karst aquifers (Quinlan and others, 1986). Pronounced troughs in the potentiometric surface occur within the confined zone of the Edwards aquifer, which are evidence for major high-permeability conduits (Worthington, 2004; Hovorka and others, 2004; Roberto Esquilin, Edwards Aquifer Authority, written commun., 2003). Hydraulic gradients along the major flow lines to Comal and San Marcos Springs display profiles that are concave, as is typical of karst aquifers (Worthington, 2004). An increase in size or number, or both, of conduits as the springs are approached might be indicated by a marked increase in hydraulic conductivity in a downgradient direction along the major flow path to Comal Springs (Worthington, 2004).

Numerical ground-water-flow models of karst aquifers commonly require appreciable increases in measured hydraulic conductivity (upscaling) to make simulated hydraulic heads and springflows match measured hydraulic heads and springflows (Halihan and others, 2000; Scanlon and others, 2002; Hovorka and others, 2004). Hydraulic conductivity in a heterogeneous medium depends on the scale at which it is defined (scaling effect) (Painter and others, 2002). Single-borehole-based hydraulic-conductivity measurements require upscaling to apply to areas the size of model cells. In a porous medium, upscaling generally is not needed and the geometric-mean hydraulic conductivity derived from aquifer tests can be used for aquifer simulations. For the Edwards aquifer, however, there is a pronounced scaling effect and hydraulic-conductivity values higher than those measured are needed to accurately simulate measured heads and springflows. Worthington (2004, fig. 11) demonstrated that the scaling effect for the Edwards aquifer is similar to that of other karst aquifers and, on the basis of this similarity, concluded that the Edwards aquifer has a well-developed conduit network. Upscaling in a numerical ground-water-flow model can be accomplished either by distribution of large hydraulic conductivity through a wide zone (Klemt and others, 1979; Maclay and Land, 1988; Scanlon and others, 2002) or by addition of a smaller number of largeaperture conduits (Worthington, 2004).

\section{Conduit Distribution and Characterization}

Techniques for determining the distribution and characteristics of conduits are not well developed. Worthington, Ford, and Beddows (2000) report that only about 2 percent of randomly drilled wells intersect a major (about $3 \mathrm{ft}$ or greater diameter) conduit in a karst aquifer. The remaining 98 percent of wells intersect the rock matrix and fractures and possibly small conduits. In the Edwards aquifer, measurements by Hovorka and others (1998) using several methods also show that only about 2 percent of the rock volume is occupied by 0.4-in.-diameter or larger conduits. However, a recent cursory examination of geophysical logs and other borehole evaluation data indicated that voids 6 in. or larger, interpreted as conduits, were noted in 29 percent of the wells analyzed (A.L. Schultz, 
consultant, written commun., 2004). Such voids, typically less than $5 \mathrm{ft}$ thick, were detected over a broad area of the San Antonio segment of the Edwards aquifer. Interpretations based on the data examined are subject to revision and improvement as additional borehole data are acquired and examined.

Integrating and comparing a suite of conduit indicators increase data density, and therefore the potential for better defining narrow conduit locations (Hovorka and others, 2004). Halihan and others (2000) state that hydraulic properties indicate that most wells in the Edwards aquifer are not closely connected to large-aperture conduits with turbulent flow. However, conduit flow is a critical factor in aquifer performance, especially aquifer capacity to store water during periods of low recharge.

To identify, measure, and monitor the conduits, it is important to examine available information for evidence as to their distribution and characteristics. Hovorka and others (2004) interpreted and integrated a selection of existing diverse data to better characterize the hypothesized conduit system for the San Antonio segment of the Edwards aquifer. Datasets selected as a basis for this interpretation included (1) water-level data, (2) structural information, (3) cave maps, (4) existing waterchemistry data, and (5) well hydrographs. Five conduit indicators were considered: potentiometric-surface troughs, wells with no drawdown when pumped, small dissolved solids concentrations, calcite undersaturation, and large (greater than $30 \mathrm{mg} / \mathrm{L}$ ) nitrate concentrations. These indicators are not unequivocal evidence that a well intercepted a conduit because other explanations for the observations are possible.

A regionally extensive system of high-permeability zones is defined by broad troughs in the potentiometric surface (conduit indicators) in the confined zone of the Edwards aquifer. Indications of connections of the confined aquifer to the recharge zone are less well defined by troughs in the available water-level data. Worthington (2004) conceptualized a dendritic pattern of conduit connection from the recharge zone to the confined zone. Three approximately synoptic water-level maps constructed by Hovorka and others (2004, figs. 7, 8, 9) show two main trends: (1) a steep and fairly uniform gradient of more than 100 feet per mile (ft/mi) between the Edwards and Trinity aquifers and (2) a gradual gradient from east to west ranging from $1.2 \mathrm{ft} / \mathrm{mi}$ in the eastern part of the aquifer steepening to $2.8 \mathrm{ft} / \mathrm{mi}$ in eastern Medina County. Superimposed on these regional trends are a number of troughs and divides. Prominent in all three water-level maps is a wide trough that extends westward from central Bexar County to western Medina County. This trough is clearly defined in synoptic surveys compiled by EAA (Roberto Esquilin, Edwards Aquifer Authority, written commun., 2003; Hovorka and others, 2004, fig. 10) and has been recognized as a zone of large hydraulic conductivity in previous models (Klemt and others, 1979; Maclay and Land, 1988; Painter and others, 2002). In all three water-level maps, the trough can be traced westward to Uvalde County. Westward into Kinney County, the trough becomes broad and poorly defined. Numerous subtle troughs or notches in the steep gradient between the Trinity and Edwards aquifers are interpreted as indicators of more transmissive zones. Data density is inadequate to define sharp troughs or subtle complexity of flow across the large-throw faults that separate the Trinity aquifer from the Edwards aquifer.

Relatively high porosity and permeability in the deepest parts of the aquifer near the freshwater/saline-water interface, anomalously high well yields, and sharp chemical gradients indicate that flow might be focused near the interface. A gradient toward the interface is recognized along most of its extent from San Marcos and Comal Springs to western Medina County (Hovorka and others, 2004, figs. 7, 8, 9). West of Medina County, data are inadequate to define the gradient in the deepest part of the aquifer.

Caves provide important but incomplete information about the characteristics of conduits. Cave maps only show a small fraction of the potential conduit flow that occurs within an aquifer. The longest distance that a cave stream in the saturated zone has been followed is only about $12 \mathrm{mi}$ (Worthington, 2004). Cave maps focus on unsaturated parts of aquifers because permanently flooded conduits are very difficult to explore. Cave apertures are at the upper end of the range of 0.4- to 40-in.diameter conduits that characterize the Edwards aquifer flow system (Hovorka and Mace, 1997; Halihan and others, 2000). Many studies have focused on detailed analysis of cave systems as indicators of hydrologic evolution (for example, White and White, 1989; Palmer, 1991; Klimchouk and others, 2000). Hovorka and others (2004) examined a large body of lessdetailed data to look for trends that can be used to infer the orientation of large-aperture conduits in the saturated zone. Edwards aquifer caves are mostly small and have rather simple geometries. The subsurface extents of 90 percent of Edwards aquifer caves that have been mapped ( 236 caves) lie within a 250-ft circle centered on the entrance (Hovorka and others, 2004). However, the longest mapped subsurface extent of an Edwards aquifer cave is more than 18,000 ft long (Elliot and Veni, 1994). For caves that could be interpreted with respect to controls on cave orientation, about one-half the caves are elongated along the direction of principal faults. This orientation reflects the importance of opening-mode fractures (those that result from extension stress, as opposed to shear stress) parallel to the Balcones fault zone in controlling permeability. Dominant opening-mode fracture systems in an extensional tectonic setting (Ferrill and Morris, 2003) are expected to parallel major faults. The other one-half of the horizontally elongated caves are oriented in other directions, reflecting multiple fracture systems in this structurally complex system. A local gradient toward a local discharge point is interpreted to be a possible indicator of elongations of some cave patterns.

Karst processes are closely associated with surface- and ground-water chemistry. Hovorka and others (2004) investigated whether general chemical trends could be useful in understanding conduit flow. As a first approximation, salinity as indicated by dissolved solids concentration is assumed to be a surrogate for residence time in the aquifer and recharge-water interaction with the aquifer matrix. The most saline water would be in the areas with the poorest interconnection and longest 
residence time, and the freshest water would be either in the recharge zone or in the fastest (most directly connected) flow paths in or near conduits. High-salinity water (greater than 3,000 $\mathrm{mg} / \mathrm{L}$ dissolved solids concentration) indicative of long residence times is in the deep, downdip part of the Edwards aquifer and in parts of the Trinity aquifer. These areas could be interpreted as regions bypassed by recharge water low in dissolved solids moving through conduits. Some samples from the Trinity aquifer have salinities in the same range as that typical of Edwards aquifer water (200 to $500 \mathrm{mg} / \mathrm{L}$ dissolved solids concentration). These might indicate faster, directrecharge flow paths that communicate from the Trinity aquifer to the Edwards aquifer and from the Edwards aquifer recharge zone through the Trinity aquifer and back into the Edwards aquifer. About 5 percent of the samples from the confined zone of the Edwards aquifer are greatly undersaturated with respect to calcite, which is interpreted as an indicator of rapid conduit flow with little reaction between rock and water (Hovorka and others, 2004). Undersaturated samples are not disproportionately clustered in the major conduit zones defined by troughs in the potentiometric surface, interpreted to mean that a secondary network of conduits is active, with ground-water velocities adequate to limit rock-water equilibration. Water that recharges by turbulent flow through large-diameter conduits can remain unsaturated. This is interpreted as the origin of very undersaturated water at depth in Medina, Bexar, Comal and Hays Counties.

Shallow flow paths, close to the water table, commonly have been considered the most favored locations for conduits (Thrailkill, 1968; Maclay, 1995). Reasons proposed for this assumption included shorter distances than for deeper flow paths and larger fracture apertures more likely close to land surface. However, abundant evidence exists for solution activity deep within carbonate aquifers. Mechanisms of deep conduit formation include (1) slow solution kinetics, (2) mixing corrosion, (3) calcium sulfate solution driving dedolomitization, (4) sulfur oxidation, (5) carbon dioxide charging, (6) temperature dependence of viscosity, and (7) microbiology effects in both facilitating and slowing carbonate solution (E.C. Alexander, Jr., University of Minnesota, written commun., 2004). Worthington (2001) demonstrated conduit formation deep below the water table in cases where sink-to-springflow paths are longer than about $1.9 \mathrm{mi}$, which results from lower viscosity and greater flow at depth because of geothermal heating. An analysis by Worthington (2004, p. 19) for three possible flow paths from sinks at the Frio River to Comal Springs indicated that "deeper parts of the Edwards aquifer are favored over shallower parts for conduit development, even when the deep flow path is up to 24-percent longer than the shallow flow path."

Conduit development in the Edwards aquifer has proceeded (1) from the surface in the recharge zone, (2) by several mechanisms deep within the aquifer, and (3) upgradient from the springs. However, conduit development in the recharge zone of the Edwards aquifer might be inhibited relative to that near the springs, on the basis of results reported by Liedl and others (2003). They indicated that if water entering conduits in the recharge area is calcite rich, then karst development propagates from the spring rather than from the recharge area, whereas undersaturated recharge water will cause conduits to propagate from both ends. Therefore, if streamflow becomes saturated with respect to calcite as it crosses the Edwards Plateau, conduit development in the recharge zone might be less than conduit development near the springs in the confined zone.

Grabens and synclines are particularly favorable sites for development of conduits, offering the advantages of deeper flow paths without the disadvantages of long flow paths (Worthington, 2004). Large-scale structural troughs with increased flow occur in the Edwards aquifer, and conduit development in these is favored. Worthington (2004, fig. 17) identified nine major structural troughs in the San Antonio segment of the Edwards aquifer, including troughs in central Uvalde, Medina, and Bexar Counties, southwestern Medina County, within the recharge zone in Comal County, and near the freshwater/saline-water interface from west of Comal Springs to San Marcos Springs. Favorable structural location can be inferred to be an important factor in conduit development in the aquifer, on the basis of the close alignment between potentiometric-surface troughs and many of the structural troughs, as well as the position of the known highest-yielding Edwards aquifer well (Rettman, 1991) in a major structural trough. In Bexar County, potentiometric-surface troughs are difficult to identify because of the large ground-water withdrawal rates by the City of San Antonio and the low hydraulic gradients in the confined zone of the aquifer. However, the existence of a plume of freshwater identified by low electrical conductivity in the southern part of the confined zone in Bexar County just to the south of the Bexar County index well (J-17) and San Pedro and San Antonio Springs indicates rapid flow from the recharge zone of this dilute water (Worthington, 2004, fig. 19).

Studies conducted by Hovorka and others (2004) and Worthington (2004) are in agreement about the presence and hydrologic significance of conduits. Many variations in interpretation of the geometry of conduits can be noted, however; these areas will serve to focus future data collection. The locations of conduits in the Edwards aquifer were inferred by Worthington (2004, fig. 21) for inclusion in the Edwards aquifer model (fig. 7). Considerations in the placement of the conduits include the following (Worthington, 2004):

1. The locations of the conduits are based on a number of factors, including major potentiometric-surface troughs in the aquifer, the presence of sinking streams, geochemical information, and geologic structures (for example, faults and grabens).

2. As far as possible, the conduit locations are consistent with the most comprehensive available potentiometricsurface maps of the aquifer.

3. The confined-zone conduit segments, other than those near the freshwater/saline-water interface, are based on potentiometric-surface troughs and geologic structure. 


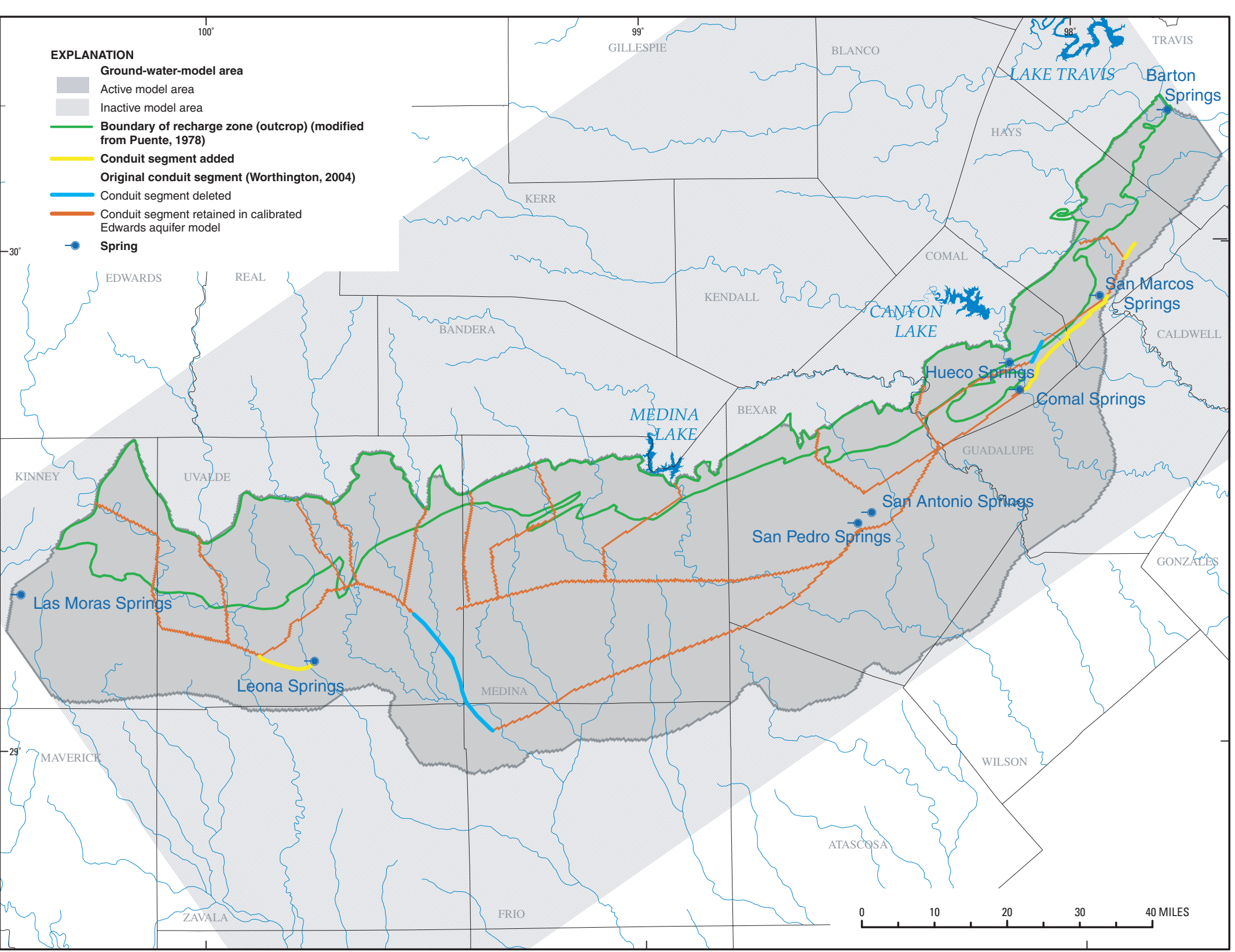

Figure 7. Inferred locations of conduits in the Edwards aquifer, San Antonio region, Texas. 
4. The major potentiometric-surface troughs in the aquifer (near Uvalde, D'Hanis, and in Comal County), inferred locations for conduits, coincide with structural grabens. Carbonate dissolution theory also indicates that grabens are a favorable location for conduit development. Grabens, therefore, were used as a guide for locating conduits.

In Bexar County, there is a plume of water with electrical conductivity similar to or lower than that at Comal Springs, which implies one or more major conduits (Worthington, 2004). The largest hydraulic conductivity in Bexar County might be in a zone less than $1.25 \mathrm{mi}$ wide and is about 2 to $3 \mathrm{mi}$ from the freshwater/saline-water interface, on the basis of water-quality data (Worthington, 2004). This might also be the case in Medina, western Uvalde, and eastern Kinney Counties, but a lack of hydraulic-head or chemistry data close to the freshwater/saline-water interface makes this assumption uncertain. The conduit segments near the freshwater/saline-water interface are based on preferential development of conduits near the interface. A highly permeable belt of rocks exists along segments of the freshwater/saline-water interface in areas where mixing ground water of two different chemical types increases the solution capacity of the water (Maclay and Small, 1984). The southeastern part of the freshwater/saline-water interface south of Knippa might be associated with a syncline at the base of the Edwards aquifer, and conduit development in this area might have preferentially occurred in this syncline (Worthington, 2004).

Both numerical models of dissolution of carbonate aquifers and tracer tests provide evidence that continuous conduits connect sinking streams and springs in carbonate aquifers (Worthington, 2004). Therefore, the major sinking streams (rivers) were interpreted to be connected to the major springs by conduits (fig. 7) for the Edwards aquifer model. Maclay and Small (1984) hypothesized that solution channels within the Edwards aquifer might be oriented parallel to the courses of streams recharging the Edwards aquifer and that vertical solution channels are well developed below segments of stream courses in the recharge zone.

\section{Hydraulic Properties}

Information on hydraulic properties was compiled from the literature to estimate the range in measured hydraulic properties appropriate for the Edwards aquifer model. Extensive data have been collected on the hydraulic properties of the Edwards aquifer in the San Antonio region. The hydraulic properties of primary interest include hydraulic conductivity (permeability), transmissivity, anisotropy, and storativity. Hydraulic conductivity is a quantitative measure of the ability of a material to transmit water and is a property of both the medium (aquifer material) and the fluid (Lohman, 1972, p. 6). Transmissivity is computed by multiplying hydraulic conductivity times aquifer thickness. The term "permeability" is commonly used in the extensive literature pertaining to the Edwards aquifer as equivalent to hydraulic conductivity. Permeability is used in this report (1) for a qualitative description of the ability of materials to transmit water and (2) in relation to aquifer structure, for example when referring to matrix, fracture, and conduit permeability.

Hovorka and others (1995, 1998), Halihan, Sharp, and Mace (1999), Halihan, Mace, and Sharp (2000), and Mace and Hovorka (2000) conducted quantitative and interpretive assessments of the three-dimensional distribution of permeability for the San Antonio segment of the Edwards aquifer, including the contributions of matrix, fracture, and conduit permeability. Hovorka and others (2004) and Worthington (2004) characterized the role of fractures and conduits in the Edwards aquifer. Estimates of hydraulic conductivity were derived by Painter and others (2002) and assigned to the cells of the model grid developed for the Edwards aquifer model. Major products of a study by Klemt and others (1979), who developed a numerical ground-water-flow model of the Edwards aquifer for management purposes, include maps estimating storage coefficient, transmissivity, and anisotropy. A series of publications presenting the results of USGS research (Maclay and Rettman, 1973; Maclay and Small, 1976, 1983, 1984; Maclay, Rettman, and Small, 1980; Maclay, Small, and Rettman, 1980; Maclay and Land, 1988; Kuniansky, 1994; and Kuniansky and Holligan, 1994) provide an extensive database of maps, data, description, numerical modeling, and interpretation. Hovorka, Ruppel, and others (1993) and Hovorka, Dutton, and others (1996) assessed storativity in the San Antonio segment of the Edwards aquifer. Hydraulic properties for the Barton Springs segment of the Edwards aquifer were estimated by Brune and Duffin (1983), Senger and Kreitler (1984), and Slade and others (1985). Scanlon and others (2002) developed a numerical groundwater-flow model for the Barton Springs segment of the Edwards aquifer. This model was the source of initial hydraulic properties for the Barton Springs segment in the Edwards aquifer model.

\section{Permeability}

An interpretation of the distribution of permeability by stratigraphic unit of the Edwards aquifer and its confining units is shown in figure 4 . These estimates of relative permeability are qualitative approximations based on field observations, stratigraphic studies by Rose (1972), and data from test-drilling and geophysical-logging programs (Maclay and Small, 1983). For the Edwards aquifer, these estimates apply to the confined zone and might not be strictly applicable to the unconfined zone.

Permeability in the Edwards aquifer reflects interaction between rock properties, structural history, and hydrologic evolution. Matrix, fracture, and conduit permeability occur in the Edwards aquifer. The carbonate matrix of the Edwards aquifer is very permeable; however, in many intervals, the very high permeabilities resulting from conduits and fractures dwarf the matrix contribution. The permeability of a rock matrix on a fine scale depends on the porosity, pore-size distribution, and size, 
tortuosity, and connectivity of pore throats. The geometry of the pore network depends on the size and shape of the rock particles and on postdepositional modifications of the size and shape of particles and pores as materials dissolved and precipitated. The initial size of the rock particles depends on the depositional environment in which the sediment accumulated. Environments of deposition of Edwards rocks varied laterally across the region and through time (Rose, 1972; Hovorka and others, 1996). Carbonate sediments commonly are altered by a variety of processes during shallow burial, deeper burial, and uplift and exposure (Bathurst, 1975). The major diagenetic processes that affect matrix-permeability development and porositypermeability relations are (1) dolomitization, (2) calcite cementation, (3) gypsum alteration by calcitization and dissolution, and (4) intense freshwater alteration (Hovorka and others, 1998). The high permeability of the rock matrix is the result of preservation of intergranular pore space in grainstones or development of well-connected pore space because of leaching. The highest matrix permeability occurs in downdip parts of the Edwards aquifer, where mixing of freshwater and saline water has maximized dolomite dissolution (Hovorka and others, 1998). A trend of high matrix permeability is observed on both sides of the freshwater/saline-water interface. High matrixpermeability trends occur parallel to the interface and oblique to depositional facies trends.

Matrix permeability in the Maverick Basin is lower than the regional average (Hovorka and others, 1998). Dolomite dissolution, which is important in permeability enhancement elsewhere in Edwards rocks, is minimal in the Maverick Basin because of the low dolomite content of these dominantly subtidal rocks. Gypsum dissolution that resulted in collapse and fracturing of the overlying strata is interpreted as a major control on permeability in the Maverick Basin. Karstification might be less important in this area than elsewhere in the Edwards aquifer. However, increased permeability of breccia, overlying fractured carbonate, and structural deformation might partly or wholly offset the decrease in solution-enhanced conduit development in this area. Many of the Maverick Basin facies in Uvalde County have been deformed into a complex dome intruded by Cretaceous volcanics. The vertical lithologic heterogeneity in the Maverick Basin might mean that the thickness of the highly transmissive part of the aquifer is substantively reduced, with only the breccia of the Salmon Peak and McKnight Formations functioning as an aquifer (Hovorka and others, 1998).

Outcrops, which are at the highest altitudes, show abundant dissolution features and additional karst features that have developed in near-surface settings; however, matrix porosity and permeability of outcrop rocks are low relative to those in the aquifer. Geochemical processes that favor dissolution might account for greater development of both conduit and matrix permeability in the deeper parts of the aquifer. Deike (1990) used geochemical modeling to gage the importance of freshwater and saline-water mixing in driving dolomite dissolution in the Edwards aquifer. A mixing zone near the freshwater/salinewater interface provides a natural setting for rapid dolomite dis- solution. If the area of the freshwater aquifer initially expanded rapidly but subsequently slowed toward the present, greater dolomite dissolution might result in the deeper parts of the aquifer (Hovorka and others, 1998). Another possible explanation for the lower permeabilities observed in the outcrop rocks is that areas where recharge might be focused, such as streambeds (riverbeds) or sinkholes, are not represented in the datasets used in the analysis. Preferential flow through outcrop areas of focused recharge might reduce permeability enhancement in other parts of the unconfined aquifer.

\section{Hydraulic Conductivity and Transmissivity}

Hydraulic conductivity and transmissivity of the Edwards aquifer reflect matrix, fracture, and conduit permeability and each varies over several orders of magnitude. Garza (1968, p. 31) estimated the transmissivity in the confined part of the aquifer in the San Antonio area to be 1,000,000 to 2,000,000 feet squared per day $\left(\mathrm{ft}^{2} / \mathrm{d}\right)$. On the basis of numerical modeling results, Maclay and Land (1988) estimated transmissivities of more than 4,300,000 $\mathrm{ft}^{2} / \mathrm{d}$ in Comal County near Comal Springs in the freshwater confined zone of the aquifer; their smallest estimated transmissivity was $130 \mathrm{ft}^{2} / \mathrm{d}$ in the freshwater/salinewater transition zone. The transmissivity for most of the freshwater zone of the confined aquifer ranges from 430,000 to $2,200,000 \mathrm{ft}^{2} / \mathrm{d}$ and in the recharge area generally is less than $430,000 \mathrm{ft}^{2} / \mathrm{d}$ (Maclay and Land, 1988). Hydraulic conductivity and transmissivity in the Edwards aquifer both vary more than eight orders of magnitude and are multimodal (Hovorka and others, 1998). Hovorka and others (1998) reported that hydraulic conductivity ranges from $10^{-3}$ to $10^{5} \mathrm{ft} / \mathrm{d}$ and transmissivity from $10^{-1}$ to $10^{7} \mathrm{ft}^{2} / \mathrm{d}$ on the basis of specific-capacity and other aquifer tests.

\section{Distributions Within Edwards Aquifer}

Aquifer-test data provide information about the distribution of hydraulic conductivity. However, conclusions are limited because of sampling error resulting from inability to quantify the largest hydraulic conductivity through typical wellbore apertures. A dataset (hereinafter called the Mace dataset) with a few data from aquifer tests, but with most of the data from single-borehole tests, was developed to analyze hydraulicconductivity distributions in the Edwards aquifer (Hovorka and others, 1998; Mace, 2000; Mace and Hovorka, 2000). The distributions of specific capacity, transmissivity, and hydraulic conductivity are essentially lognormal, although the histograms indicate the possibility of multiple populations (Hovorka and others, 1998, fig. 22). The unevenness of the transmissivity and hydraulic-conductivity distributions indicates the possibility of multiple modes. These multiple modes indicate distinct but overlapping data populations controlled by fracture/conduit and matrix permeability, or even more complexly, overlapping populations controlled by geologic and hydrologic settings. Local- and regional-scale variability makes contouring transmissivity and hydraulic-conductivity data very difficult and lessens the applicability of "average" values. Local-scale 
variability can range over three orders of magnitude. Individual tests represent hydraulic properties at particular wells and do not represent conditions at a larger scale simulated in a numerical ground-water-flow model. Hovorka and others (1998, table 10) reported mean hydraulic conductivities, computed from specific capacity, for the outcrop (recharge zone) and confined zone of the San Antonio segment of the Edwards aquifer of 0.28 and $34 \mathrm{ft} / \mathrm{d}$, respectively, and $11.3 \mathrm{ft} / \mathrm{d}$ for the aquifer as a whole. A mean of $0.09 \mathrm{ft} / \mathrm{d}$ was reported for the hydraulic conductivity of the matrix. The estimates were increased by a minimum factor of about five if specific-capacity tests with no measurable drawdown were included. Mean hydraulic conductivity of the confined zone is more than 120 times greater than mean hydraulic conductivity in the recharge zone. If flow feeding Comal Springs is dominated by a few large conduits, the few available aquifer tests do not characterize those conduits.

Based on experimental and theoretical semivariograms (statistically based, qualitative functions that characterize spatial continuity of a dataset-that is, how quickly values change with changing distance and direction in space), Hovorka and others (1998) concluded that there are spatial relations in specific capacity, transmissivity, and hydraulic conductivity. The semivariograms indicated that small-scale variability in these hydraulic properties is large; even closely spaced measurements might differ by a factor of 1,000. The small-scale randomness most likely reflects the variable contributions of matrix, fracture, and conduit permeability to the measured average value obtained in aquifer tests. The small-scale variability should be smaller in aquifers that have only matrix permeability or only matrix plus fracture permeability. The ranges, or correlation lengths, of the variograms suggest, however, that specificcapacity, transmissivity, and hydraulic-conductivity data are spatially related within 13 to $15 \mathrm{mi}$ of a given point (Hovorka and others, 1998, fig. 26). Differences in hydraulic conductivity between tested intervals in each of 13 research wells in the San Antonio segment of the Edwards aquifer were as much as tento one-hundred-fold, indicating appreciable vertical variability in the aquifer (Hovorka and others, 1998). The more permeable intervals corresponded approximately to the regionally more dolomitic intervals. Some wells that yielded relatively large hydraulic conductivity intersect fracture sets that dominate conduit development and conduit flow and overwhelm any stratigraphic effects.

Vertical variations in hydraulic conductivity in the Edwards aquifer indicate that the entire aquifer is highly permeable as well as highly variable. Vertically averaged hydraulic conductivities of the matrix were compared with hydraulic conductivities derived from aquifer tests by Hovorka and others (1998). Mean hydraulic conductivity of the matrix was more than 100 times lower than mean hydraulic conductivities obtained from aquifer tests. Structurally influenced cave systems contribute the highest hydraulic conductivities $\left(10^{1}\right.$ to $10^{6} \mathrm{ft} / \mathrm{d}$ ), solution-enhanced fractures and stratigraphically controlled karst contribute intermediate values, and the porous carbonate matrix contributes hydraulic conductivities of $10^{-3}$ to $10^{1} \mathrm{ft} / \mathrm{d}$ (Hovorka and others, 1998). Matrix permeability accounted for a large fraction of the permeability in intervals of small hydraulic conductivity determined from aquifer tests. In intervals of relatively large hydraulic conductivity from tests, the matrix contribution was less than 1 percent. Hovorka and others (1998) found high transmissivity more frequently in the deeper parts of the Edwards aquifer than in the parts where the top of the aquifer is higher than about $200 \mathrm{ft}$ above NGVD 29.

Statistical comparison of transmissivities from tests in wells at varying distances from mapped faults (Hovorka and others, 1998) shows no strong relation between high transmissivity and proximity to faults. However, in outcrop studies, an increase in the abundance and connectivity of fractures near faults was observed, along with preferential development of large caves in fault zones. The width of highly brecciated zones adjacent to faults increases with throw on the fault. These factors indicate that transmissivity increases near faults in the San Antonio segment of the Edwards aquifer. Wells that intersect conduits or small faults not identified during regional mapping might account for some of the high transmissivities distant from faults. Many small faults and fractures are within the blocks between the large mapped faults. Abundant fractures and small faults related to structural features other than faults, such as folds and relay ramps, and variables other than structure, such as karst development, probably also account for some of the high transmissivities away from faults. Alexander (1990) reported a relation between specific capacity and distance of a well from lineaments in the Barton Springs segment of the Edwards aquifer. The specific capacities of wells less than $1,000 \mathrm{ft}$ to the southwest of lineaments were several orders of magnitude larger than those of wells farther from lineaments.

Anisotropy of an aquifer is indicated when the hydraulic conductivity shows variations with the direction of measurement at any given point in a geologic formation. Therefore, an anisotropic aquifer will have a dominant hydraulic conductivity in one or more directions depending upon geologic and hydrologic conditions. The quantitative magnitude of anisotropy of the Edwards aquifer is largely unknown. Factors that might influence anisotropy in the aquifer include the presence of barrier faults with large vertical displacements and the development of conduits. The disruption of ground-water flow by faults might be strongly influenced by major disruptions in the lateral continuity of highly permeable strata. Water circulation might cause focused dissolution and the development of conduits along the main flow paths in carbonate aquifers.

Collins (1995) indicated that vectors of transmissivity in the San Antonio segment of the Edwards aquifer trend approximately 40 degrees north to 70 degrees east because of postfault dissolution along joint cavities and solution channels aligned with the fault zone. Because faults are most abundant across northern Medina, central Bexar, southern Comal, southern Hays, and central Travis Counties (Maclay and Small, 1984, fig. 3; Baker and others, 1986, fig. 2), the strongest anisotropy exists east of Uvalde County. The ratio of anisotropy (ratio of y-direction transmissivity to x-direction transmissivity) derived from past digital-model analysis ranges from 0:1 to 1:1 (Maclay and Land, 1988). The regional maximum directional 
transmissivity is aligned parallel with structural features and prevailing ground-water flow paths.

\section{Distributions Developed For Edwards Aquifer Model}

Painter and others (2002) estimated hydraulic conductivity for the Edwards aquifer in the San Antonio region to provide initial values for the Edwards aquifer model. The broad objective was to provide improved representations of the areal distribution of vertically averaged hydraulic conductivity across the San Antonio region of the Edwards aquifer using the best available quantitative techniques. The approach used, a combination of spatial statistical methods and advanced techniques for automatic model calibration, incorporates existing data of various types and avoids manual adjustment of the hydraulicconductivity distribution. Hydraulic conductivity in heterogeneous aquifers depends on the spatial scale of the measurement. Existing hydraulic-conductivity measurements in the Edwards aquifer are mostly from single-well drawdown tests. These must be modified or "upscaled" before being applied to the 0.25 - by 0.25 -mi cells of the Edwards aquifer model (see "Model Grid" section). The initial hydraulic-conductivity distribution was derived from the Mace dataset referred to in the "Distributions Within Edwards Aquifer" section of this report (Hovorka and others, 1998; Mace, 2000; Mace and Hovorka, 2000). An approach based on nonparametric geostatistics, stochastic simulation, and numerical flow simulation was used to upscale and interpolate to the Edwards aquifer model grid. This constituted revision 1 of the hydraulic-conductivity distribution. Revision 2 of the hydraulic-conductivity distribution incorporated the use of measured hydraulic heads and an approach based on Bayesian statistics to infer hydraulic conductivity. Revision 2 was a preliminary application of the Bayesian technique and was not used because of subsequent updates to the recharge and measured hydraulic-head datasets for the Edwards aquifer model. Revision 2 is not discussed in this report. Revision 3 of the hydraulic-conductivity distribution represents a further refinement of the approach and was the initial distribution used in the Edwards aquifer model.

For the initial hydraulic-conductivity distribution, the only manipulation of the Mace dataset was to geometrically average values when multiple values (representing different tests) existed for the same well. After this averaging, the dataset contained 653 values of hydraulic conductivity in the confined zone and 108 values in the unconfined zone. Univariate statistical distributions of hydraulic-conductivity data for the confined and unconfined parts of the Edwards aquifer are reasonably well approximated as lognormal, although the distribution for the confined zone does have a lower tail that is enhanced relative to the lognormal distribution (Painter and others, 2002, fig. 2-2). The mean and variance for the confined and unconfined zones of the aquifer are substantially different, with geometric means of 18.8 and $1.3 \mathrm{ft} / \mathrm{d}$ for the confined and unconfined zones, respectively. The logarithmic variance in hydraulic conductivity is 6.4 and $9.7 \mathrm{ft} / \mathrm{d}$ for the confined and unconfined zones, respectively. The data for the single-well tests have three principal limitations, listed below:

1. The data have substantial uncertainty, resulting in enhancement of the spread in the univariate distribution as compared with the true hydraulic conductivity and a tendency to mask spatial correlation.

2. Nearly 15 percent of the single-well tests have drawdown that is below the limit of measurement and recorded as zero, thereby resulting in a bias toward low values.

3. The location data are imprecise for some of the hydraulicconductivity data, the net effect of which is to mask spatial correlation.

Revision 1 of the hydraulic-conductivity distribution was derived using a simulation approach that addresses data interpolation and the issue of scale consistency in hydraulic conductivity (Painter and others, 2002). Data interpolation was necessary because (1) the number of grid cells used in the Edwards aquifer model is much greater than the number of data points, and (2) the nodes of grid cells do not necessarily correspond to well locations where measurements of hydraulic conductivity are available. Scale consistency is an issue because hydraulic conductivity in heterogeneous formations depends on the scale over which it is defined. A systematic bias toward lower hydraulic conductivity would be introduced by the unaltered application of local-scale hydraulic conductivity derived from aquifer tests to the 0.25 - by 0.25 -mi grid cells of the Edwards aquifer model. To address the scale dependencies and thereby avoid this systematic bias, a geostatistical approach was combined with numerical simulations in developing the hydraulicconductivity distribution.

The geostatistical approach involves geostatistical analysis of the local-scale hydraulic conductivity, unconditional stochastic simulation of local-scale hydraulic conductivity, numerical flow modeling to generate grid-cell-scale hydraulic conductivity, geostatistical analysis of the grid-cell-scale hydraulic conductivity, and co-kriging of grid-cell-scale hydraulic conductivity with the local-scale hydraulic-conductivity data. The first step in the process was geostatistical analysis of local-scale hydraulic conductivity to establish models for the univariate distribution and the spatial correlation. The confined and unconfined zones of the aquifer were treated as separate populations. The next step was to establish a model for the two-point spatial correlation. Methods for doing this include the sample semivariogram and the sample nonergodic covariance or the closely related nonergodic correlogram. It is advantageous to apply these measures of spatial correlation not to the original local-scale hydraulic-conductivity data, but to some transforms of local-scale hydraulic conductivity, such as logarithmic or indicator transforms. The data from the unconfined zone of the Edwards aquifer are too few to support an indicator model, and a traditional semivariogram was computed for the logtransformed local-scale hydraulic conductivity instead. The reader is referred to Painter and others (2002) for the details of these procedures. 
Omnidirectional indicator correlograms for the confinedzone local-scale hydraulic conductivity indicated that substantial spatial correlation exists, and small values of local-scale hydraulic conductivity were better correlated spatially than the large values (Painter and others, 2002, fig. 3-2). The semivariogram for the unconfined zone, although "noisy" because of the small sample size, indicates substantial spatial correlation at small lag distances (Painter and others, 2002, figs. 3, 4).

Having established geostatistical models for the confined and unconfined zones of the Edwards aquifer that are valid for the scale of the aquifer-test data, the next step was to upscale to the scale of the grid cells used in the Edwards aquifer model (Painter and others, 2002). Upscaling meant calculating or estimating the univariate distribution of the grid-cell-scale hydraulic conductivity and a spatial cross-correlation between the log-transformed grid-cell-scale hydraulic conductivity and the block-to-point cross correlation. The result was that the geometric mean of the grid-cell-scale hydraulic conductivity for the confined zone was increased by 65 percent and the log-variance was decreased by a factor of 32 percent compared with the local-scale values. The increase in geometric mean with increasing scale is consistent with previous studies of hydraulic conductivity in the Edwards aquifer (Halihan and others, 2000). For the unconfined zone, the upscaling procedure increased the geometric mean local-scale hydraulic conductivity by 74 percent and decreased the log-variance by 29 percent. The next step was to estimate grid-cell-scale hydraulic conductivity on the basis of local-scale hydraulic-conductivity measurements. For this step, the log-transformed variables were used. Co-kriging provides the best estimate of a spatially distributed variable (log-transformed grid-cell-scale hydraulic conductivity in this case) on the basis of some correlated secondary measurements from the Mace dataset. The result is the best estimate of log-transformed grid-cell-scale hydraulic conductivity at each grid cell in the Edwards aquifer model. The result also provides the kriging variance, which quantifies the uncertainty in the estimate of log-transformed grid-cell-scale hydraulic conductivity. In general, log-transformed grid-cell-scale hydraulic conductivity is smaller in the unconfined zone than in the confined zone. The kriging variance is much larger in the unconfined zone, indicating large uncertainty in the estimated gridcell-scale hydraulic conductivity in the outcrop region, mostly because of undersampling in the outcrop region. The final step is to convert the log-transformed grid-cell-scale hydraulic conductivity to the best estimate of grid-cell-scale hydraulic conductivity. The largest regions of high grid-cell-scale hydraulic conductivity correspond approximately to the highpermeability zone underlying the San Antonio area (Painter and others, 2002, figs. 3-5c).

Hydraulic-head data imply considerable information about the underlying hydraulic-conductivity distribution. In revision 3 of the hydraulic-conductivity distribution, revision 1 was taken as a starting point and then modified to be more consistent with measured hydraulic-head data (Painter and others, 2002). Specifically, a recently developed Bayesian updating procedure (Woodbury and Ulrych, 1998, 2000) was used to update the hydraulic-conductivity distribution. In this approach, the nonunique nature of the inverse problem is explicitly acknowledged, and the results are given in terms of probability distributions for the hydraulic conductivity in each cell. In addition, the Bayesian method allows prior information of various types to be incorporated into the inversion procedure, allowing the previous work on upscaled hydraulic conductivity (revision 1) to be retained and used in the inversion. The model parameters were assumed to be random, and the inversion approached from the viewpoint of probability theory, with Bayesian solutions being sought for the problem. The reader is referred to Painter and others (2002) for a more detailed discussion of this method.

The Bayesian updating method requires simulation with a conventional ground-water-flow model as one step, which in this case was based on computational grids, withdrawal data, boundary conditions, and recharge data from the Edwards aquifer model. The calibration targets were 153 measurements of steady-state hydraulic head. Of the original 153 measurements, 26 were in regions of extreme gradient of hydraulic head and were deleted from the target dataset. The large-gradient areas caused large numerical error in the inversion method. Revision 1 of the hydraulic-conductivity distribution was used to set the prior distribution in the inversion process. Specifically, maps of Edwards aquifer thickness were used in conjunction with the expected values of hydraulic conductivity to set the prior log-transformed transmissivity. The objective of the inversion was to determine the expected upscaled transmissivity field of the Edwards aquifer conditioned on the hydraulic-head measurements and the upscaled log-transformed transmissivity field. The prior log-transformed transmissivity was increased in the areas immediately surrounding Comal and San Marcos Springs on the basis of the observed large springflows. The geostatistical estimates of the Bayesian updating procedure, revision 3 of the hydraulic-conductivity distribution, are of vertically averaged hydraulic conductivity rather than transmissivity, consistent with the required input for the Edwards aquifer model. In general, hydraulic conductivity was increased compared with the prior hydraulic conductivity, especially in the area just east of Knippa gap (Painter and others, 2002, fig. 4-2). The estimated hydraulic conductivity for revision 3 ranges from less than or equal to 20 to $7,347 \mathrm{ft} / \mathrm{d}$ (fig. 8).

In addition to the areal distribution of vertically averaged hydraulic conductivity across the San Antonio region of the Edwards aquifer developed by Painter and others (2002), hydraulic-conductivity estimates for zones of very high permeability corresponding to conduit locations were needed for the Edwards aquifer model. Garza (1968, p. 31) and Maclay and Land (1988) estimated maximum transmissivity of from $2,000,000$ to more than $4,300,000 \mathrm{ft}^{2} / \mathrm{d}$ for the Edwards aquifer. Corresponding hydraulic conductivities for these high transmissivities would be on the order of 10,000 to $20,000 \mathrm{ft} / \mathrm{d}$. Hovorka and others (1998) reported maximum hydraulic conductivity on the order of $10^{5} \mathrm{ft} / \mathrm{d}$. Therefore, hydraulic conductivities on the order of $10^{4}$ to $10^{5} \mathrm{ft} / \mathrm{d}$ were assumed to be representative of narrow, high-permeability, conduit-like zones in the Edwards aquifer (fig. 7). 


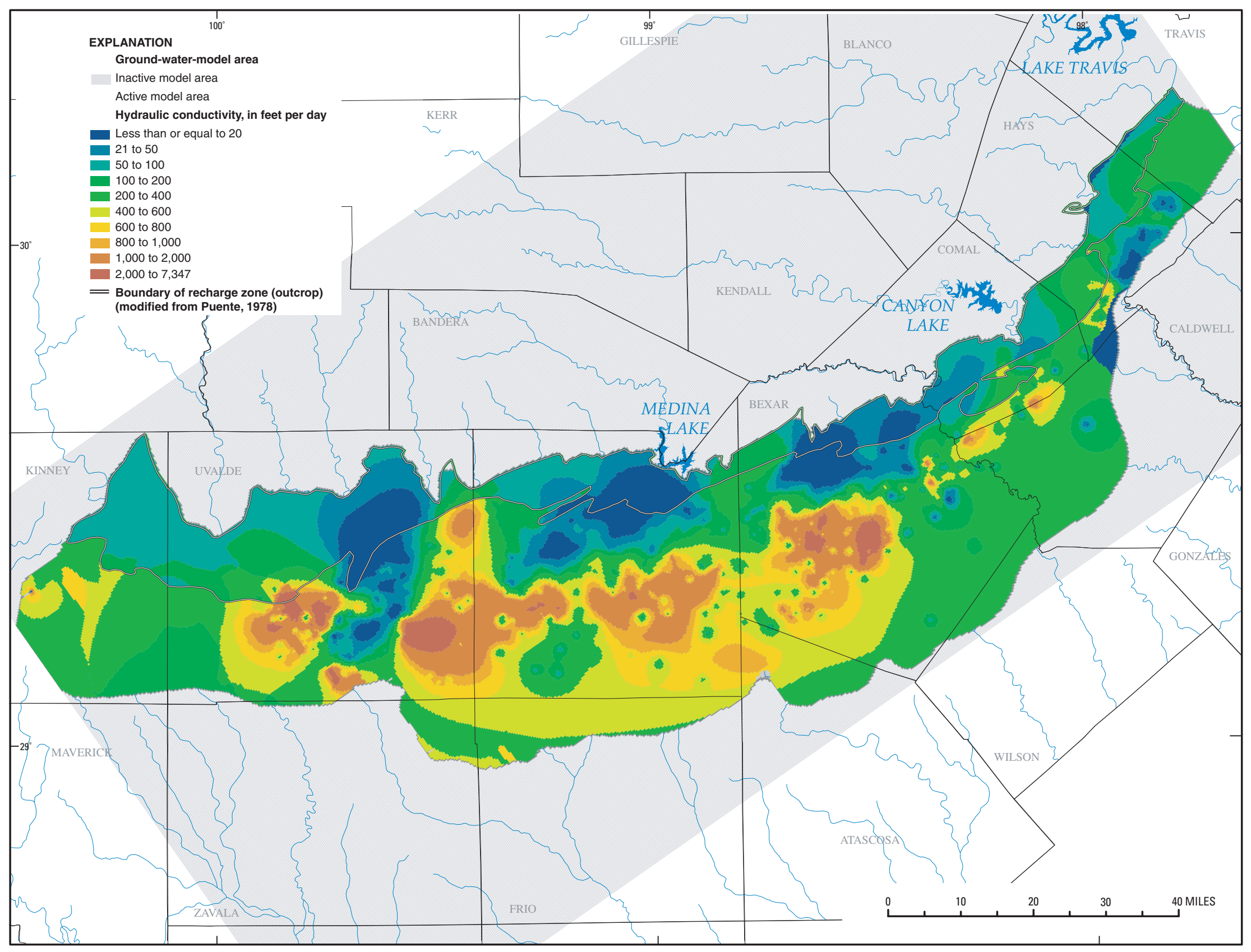

Figure 8. Distribution of horizontal hydraulic conductivity for the Edwards aquifer, San Antonio region, Texas (Painter and others, 2002). 


\section{Storativity}

The amount and distribution of water in the Edwards aquifer are related to the development of porosity and the storage characteristics of the aquifer. Hovorka and others (1996) estimated that Edwards aquifer porosity varies vertically from lows of 4 to 12 percent to highs of 20 to 42 percent, with an average for the entire aquifer of 18 percent. Reported estimates of specific yield for the San Antonio segment of the Edwards aquifer range from 0.025 to 0.20 (Maclay and Rettman, 1973; Klemt and others, 1979; Maclay and Small, 1984; Maclay and Land, 1988) and for the Barton Springs segment from 0.005 to 0.06 (Brune and Duffin, 1983; Senger and Kreitler, 1984; Slade and others, 1985; Scanlon and others, 2002). Previously reported values of storage coefficient for the San Antonio segment of the aquifer range from $1 \times 10^{-5}$ to $8 \times 10^{-4}$ (Sieh, 1975; Klemt and others, 1979; Maclay and Small, 1984; Hovorka and others, 1993). Reported specific storage for the Barton Springs segment ranges from $1 \times 10^{-6}$ to $2.9 \times 10^{-2} \mathrm{ft}^{-1}$ (Brune and Duffin, 1983; Slade and others, 1985; Scanlon and others, 2002).

High average porosities have been identified in the northern part of the Edwards aquifer in Hays, Comal, and Bexar Counties, in the western part of the aquifer in the Salmon Peak Formation of Kinney and Uvalde Counties, and near the freshwater/saline-water interface in southern Medina and Bexar Counties (Hovorka and others, 1996). Hovorka and others (2004) hypothesized that the ratio of storage in matrix to storage in fractures and conduits might be higher in the western part of the San Antonio segment of the Edwards aquifer than in the more extensively karst-modified eastern part. In western Medina County, the zone that stores water occurs over a fairly broad area generally coinciding with the Devils River trend. This area might represent a maximum in matrix storativity because of high porosity, but a minimum in solution enlargement of conduits because dolomite is a minor phase within the rock (Hovorka and others, 2004).

\section{Ground-Water-Flow System}

Ground-water flow in karst typically includes diffuse or matrix flow (slow flow system), flow through fractures, and flow through large conduits (fast flow system). Flow in conduits is rapid, often turbulent and restricted to discrete pathways, whereas flow in the matrix system is more comparable to Darcian flow in porous media (Shuster and White, 1971). Atkinson and Smart (1981) reported that the presence of turbulent flow in conduits is the definitive characteristic of karst aquifers. Hauwert, Johns, and Sharp (2002), Hauwert, Sansom, and others (2002), Schindel and others (2002), and Worthington (2004) presented results indicating that turbulent flow occurs in conduits in the Edwards aquifer. The porous matrix rock can act either as a sink draining water from the conduits or as a source supplying the conduits with water from aquifer storage (Bauer and others, 2003). In the Edwards aquifer, high matrix porosity and permeability likely are overshadowed by high permeability developed in structurally influenced karstic conduit systems that transmit water into, through, and out of the aquifer.

The ground-water-flow system of the Edwards aquifer in the San Antonio region includes the following components (figs. 2, 9):

1. The catchment area in the Edwards Plateau, where the rocks of the Edwards-Trinity and Trinity aquifers are exposed and receive direct recharge to the water table. Erosion has removed Edwards Group rocks in the Hill Country, as the southern margin of the plateau is known locally (hence Trinity aquifer rather than Edwards-Trinity aquifer in the Hill Country).

2. The recharge zone in the northern and northeastern parts of the Balcones fault zone, where streams lose flow directly into the unconfined Edwards aquifer, and the aquifer receives direct recharge to the water table.

3. The confined zone in the southern and southeastern part of the Balcones fault zone, which comprises the freshwater zone and the freshwater/saline-water transition zone.

\section{Regional Ground-Water Flow}

A recent potentiometric-surface map for the Edwards aquifer (Roberto Esquilin, Edwards Aquifer Authority, written commun., 2004) (fig. 10). indicates that water that entered the catchment area and recharge zone moves from unconfined to confined parts of the aquifer through generally southeasterly flow paths. In the confined zone, the water moves under low hydraulic gradients through fractured, highly transmissive, cavernous strata toward the east and northeast, where it is discharged through springs and wells.

The ground-water flow units shown in figure 10 were identified by Maclay and Land (1988) on the basis of numerical ground-water-flow modeling results. A flow unit of the San Antonio segment of the Edwards aquifer is defined as an area of the aquifer that includes a storage unit and a zone in which water is transmitted from this storage unit to major points of discharge. Maclay and Land (1988) indicated that four subareas of the recharge zone tended to function as independent flow units because of faults. Some interchange of ground water from one flow unit to another probably occurs at different water-level conditions. However, the flow units are not expected to vary substantially with historical changes in water levels (Maclay and Land, 1988).

Regional trends in hydraulic gradients include (1) a broad, low-gradient part of the aquifer in the confined zone in Medina and Bexar Counties, (2) generally steeper hydraulic gradients in the confined zone to the west and east of Medina and Bexar Counties and in the recharge zone, and (3) generally steep gradients across the transition from the unconfined to confined parts of the Edwards aquifer. In the Barton Springs segment of the aquifer, the ground-water-flow direction generally is 


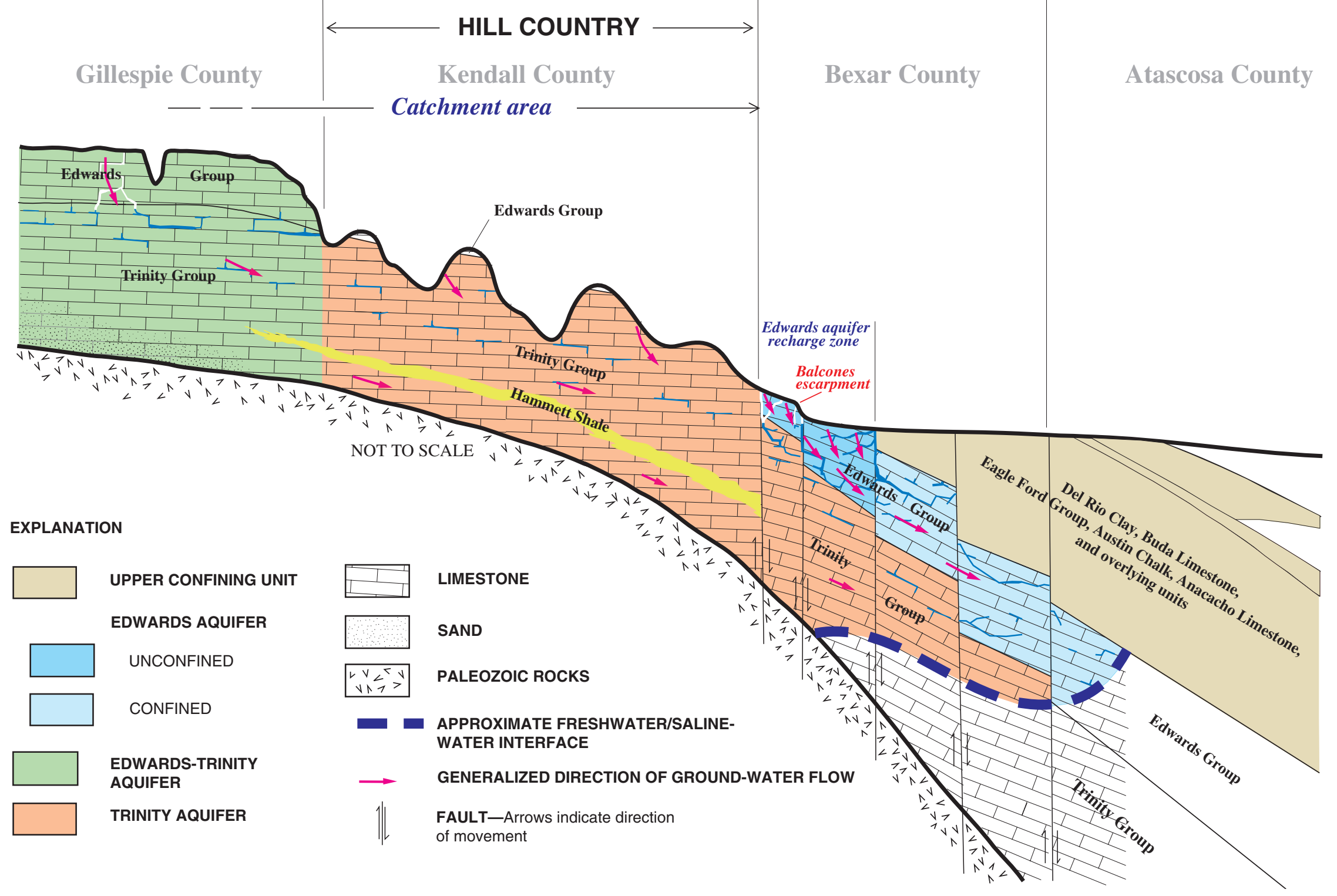

Figure 9. Diagrammatic north-northwest-to-south-southeast section showing hydrogeologic framework and generalized ground-water-flow directions, Edwards Plateau to Gulf Coastal Plain, San Antonio region, Texas (modified from Barker and Ardis, 1998, pls. 1 and 3). 


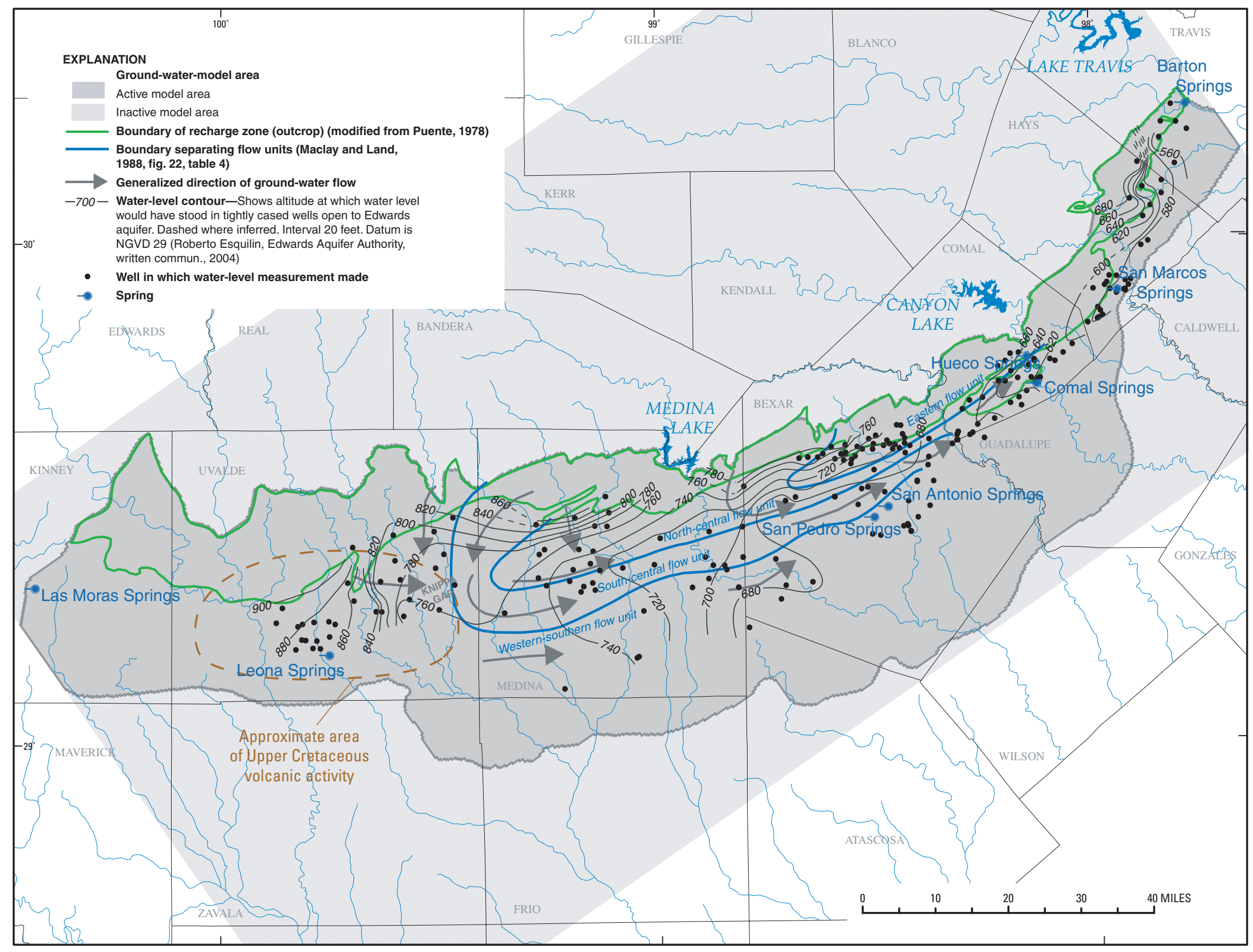

Figure 10. Potentiometric surface and inferred regional ground-water-flow pattern in the Edwards aquifer, 0ctober 27-November 2, 2001, San Antonio region, Texas. 
southeast from the recharge zone to the confined zone and northeast toward Barton Springs.

Conduits could be major contributors to flow in the Edwards aquifer (Hovorka and others, 2004; Worthington, 2004). The multimodal permeability distribution of the Edwards aquifer (Hovorka and others, 1998) implies that the fastest-moving water can travel many times faster than the largest volume of water. Based on comparisons between mean matrix permeability and mean hydraulic conductivities estimated from aquifer tests, the contribution of matrix permeability to regional-scale hydraulic conductivity likely is minor and most Edwards aquifer water flows through fractures and conduits (Hovorka and others, 1998). Both Hovorka and others (2004, fig. 24) and Worthington (2004, fig. 21) infer the presence of conduits and major flow paths from central Bexar County to western Medina County, with an east-west trend that indicates structural influence. Hovorka and others (2004) postulate a complex of interconnected conduits, with about one-half the segments parallel to faults and one-half of them crossing faults at an appreciable angle. The presence of conduits and major flow paths also are indicated (1) in a potentiometricsurface trough that loops northward around volcanic intrusions in southeastern Uvalde County, (2) along parts of the freshwater/saline-water interface in Medina and western Bexar Counties, (3) mostly near the freshwater/saline-water interface between Comal Springs and eastern Bexar County, and (4) in a large graben system within the outcrop in southern Comal County. The inferred conduit between Comal Springs and eastern Bexar County is parallel to major faults near Comal Springs but crosses faults at a high angle to occur deeper in the subsurface in Bexar County (Hovorka and others, 2004).

Proximity to large faults and high dolomite content indicated by facies distribution and mapped by Rose (1972) indicate that conduits are major contributors to flow in the confined zone of the Edwards aquifer in Hays and Comal Counties (Hovorka and others, 1998). Maclay and Small (1984) assigned this zone the highest transmissivities in the aquifer. The discrete-state compartment model of Campana and Mahin (1985) indicated high effective porosity in the confined zone in Comal County. In the Barton Springs segment of the Edwards aquifer, numerical ground-water-flow modeling by Slade and others (1985) and Scanlon and others (2002) identified large hydraulic conductivities near the major discharge point at Barton Springs. Poor connectivity occurs near the ground-water divide between the San Antonio and Barton Springs segments of the aquifer. However, a narrow zone within a graben north of San Marcos Springs is fully saturated and contains several wells which, when pumped, yielded no measurable drawdown and several wells that yield water that is undersaturated, with respect to calcite, which indicate a likely location of a conduit and rapid ground-water flow (Hovorka and others, 2004). The freshwater part of the Edwards aquifer in the confined zone is extremely narrow, or perhaps nonexistent, in sections between San Marcos and Comal Springs. Large-throw faults in this area displace the Edwards rocks, so that at the freshwater/saline-water interface, Edwards rocks are completely offset. Worthington
(2004, fig. 21) hypothesized that rather than flowing through the confined zone, appreciable amounts of water move through conduits within the large graben system in the Edwards aquifer outcrop area in southern Comal County.

Water-level maps show a complex, poorly defined flow pattern in central Uvalde County, probably reflecting rock complexity in this area with complex structural and volcanic intrusions. Wells without measurable drawdown occur in disproportionate numbers near Leona Springs and along a zone trending northwestward from them (Hovorka and others, 2004). Details of the connectivity of flow through this area are unclear; however, a network of conduits is inferred from available data. A steepening of the Edwards aquifer potentiometric-surface gradient occurs in eastern Uvalde County in the area of the Knippa gap. Maclay and Land (1988) characterized the area of steepening as the Knippa gap, and interpreted it as a narrow opening within an extensive, complex barrier-fault system. More detailed structural mapping has complicated the interpretation of faults (fig. 5), and no structural restriction of flow is apparent coincident with the steeper gradient. From central Uvalde County, ground water flows southward and downdip toward southeastern Uvalde and southwestern Medina Counties. Worthington (2004, fig. 21) postulated the presence of conduits along this southeastward flow path partially within a syncline at the base of the Edwards aquifer. However, spatial and temporal data density is inadequate to define the flow characteristics of this important region of the aquifer.

Faults can either increase or decrease total transmissivity (Hovorka and others, 1998). Some of the abundant, interconnected fractures in intensely fractured zones adjacent to faults have been enlarged, and they might focus flow parallel to faults. Where calcite cement fills breccia, cross-fault flow might be decreased. Stratigraphic offset of permeable zones along faults might also decrease the cross-fault flow (Maclay and Small, 1983, 1984). Holt (1959) observed nearly $100 \mathrm{ft}$ of head difference across faults in northern Medina County, and George (1952) reported head differences of 6 to $26 \mathrm{ft}$ across segments of major faults in unconfined, less-transmissive parts of the aquifer in Comal County. Maclay (1995) and Groschen (1996) characterized flow in the Edwards aquifer as being controlled laterally by barrier faults that locally compartmentalize the aquifer, especially toward the eastern part of the San Antonio segment. Maclay and Land (1988) hypothesized that largethrow faults segment the aquifer and divert flow entering the recharge zone on relay ramps (transfer zone accommodating deformation between normal fault segments with similar dip directions [Peacock and Sanderson, 1994]) to the west before flow is redirected toward the east.

Several 3- to 7-mi-long sections of large-throw faults are coincident with a steep gradient between the confined and unconfined sections of the Edwards aquifer. This fact implies that faults or stratigraphic juxtaposition limit cross-fault flow; however, notches across faults in water-level maps suggest that more transmissive zones provide connections between the recharge zone and the confined aquifer (Hovorka and others, 2004). Notches can be interpreted as inferred conduit axes, 
although the steep gradient demonstrates that flow properties of such notches are different from those of the confined zone. The steep gradient might also indicate flow discontinuities. Superimposing faults on the low-water-level map from Hovorka and others (2004, fig. 23) shows several areas of steep gradient coincident with faults, but in most areas the water-level change appears to be gradational rather than sharp. Small water-level troughs that cross the faults that juxtapose the Trinity aquifer against the Edwards aquifer are poorly defined but generally appear to be perpendicular to the faults. Only at large-throw faults is there a transition directly from recharge (unconfined) zone to confined zone across a fault boundary. In the western part of the San Antonio segment of the aquifer, the change from unconfined to confined conditions is more transitional. Worthington (2004, fig. 21) mapped the inferred locations of conduits in northern Medina County that are oriented along major faults, rather than crossing them, based on 1951 and 1952 potentiometric-surface maps (Holt, 1959) that indicated that flow to the south in the confined zone in the area is blocked by faults. For the most part, however, the conduits as inferred by Worthington (2004, fig. 21) cross faults. Liedl and others (2003) simulated conduit evolution in which carbonate dissolution was determined solely by the nearly saturated water, with respect to carbonate species, derived from a matrix/fractured aquifer system. The results indicated that conduit development proceeded more rapidly as a function of the mean flow gradient. This finding demonstrates a possible reason and potential for the development of conduits in a downgradient direction transverse to faults near the outcrop in the Edwards aquifer.

Hovorka and others (2004) determined the saturated thickness of the San Antonio segment of the Edwards aquifer, computed as the water-level altitude minus the altitude of the top of the Trinity aquifer (Glen Rose Limestone). The findings indicate that the Edwards Group is saturated over only a part of the recharge zone, which suggests that recharge flows through the Edwards Group into the upper beds of the underlying Glen Rose Limestone before returning to the Edwards. Veni (George Veni and Associates, written commun., 2003) has documented cave patterns in the northern Bexar County area, as well as other locations in the Edwards aquifer recharge zone, that indicate that the upper part of the Glen Rose Limestone is hydraulically connected to the Edwards Group.

Steep gradients of $100 \mathrm{ft} / \mathrm{mi}$ are mapped where groundwater flow enters the Edwards aquifer from the Trinity aquifer in the recharge zone (Hovorka and others, 2004). Possible interpretations of these steep gradients include (1) cross-formational flow paths are much less transmissive than those in the Edwards aquifer confined zone (Hovorka and others, 2004) and (2) freesurface cascades or water falls (E.C. Alexander, Jr., University of Minnesota, written commun., 2004). Spring discharge at the Trinity aquifer-Edwards aquifer contact indicates that perched water tables or flood-stage perched conduits might affect the transmission of water through the recharge zone, and freesurface underground streams are common in area caves.

The freshwater/saline-water interface marks the downdip boundary of the freshwater zone of the Edwards aquifer in the
San Antonio region (figs. 2, 9). The interface is complex in three dimensions and appears to be hydrodynamically controlled. In most areas, salinity increase is gradual over a mapped transition zone several miles wide and can be contoured (Clement, 1989; Schultz, 1993, 1994; A.L. Schultz, consultant, written commun., 2000). However, in some areas, such as near San Marcos Springs, the transition zone is less than $300 \mathrm{ft}$ wide. The lateral complexity of the transition zone from freshwater to saline water has been documented by Schultz (1993, 1994; A.L. Schultz, consultant, written commun., 2000), who mapped the zone in detail using resistivity logs.

Freshwater and downdip saline water are not separated by a known barrier to flow in most parts of the Edwards aquifer. The freshwater zone and the transition zone are hydraulically connected, but the aquifer transmits water in the freshwater zone at a much greater rate than in the transition zone (Schultz, 1992). Because the freshwater/saline-water interface is not known to be a hydrologic barrier, a potential exists for the boundary to move. If pressure is an important factor in controlling the location of the interface, saline-water migration could occur in response to lowered water levels (Perez, 1986; Technical Advisory Panel, 1990). Geochemical interpretation of water compositions (Clement, 1989; Oetting, 1995) and widespread areas of moderate salinity (3,000 to $10,000 \mathrm{mg} / \mathrm{L}$ dissolved solids concentration) away from faults (Schultz, 1993) document slow movement of freshwater into the transition zone, where the observed water chemistry shows evidence of mixing. In the central part of the Edwards aquifer in Medina County, conductivities computed from resistivity logs (Schultz, 1994) and information from test wells (Waugh, 1993) document that freshwater and saline water interfinger vertically. Within the transition zone of the Edwards aquifer, the highest matrix porosity and permeability is near the updip edge, although hydraulic conductivity is toward the low end of the range measured in the aquifer (Hovorka and others, 1998). The hydraulic conductivity of the matrix computed for wells near the updip edge of the transition zone is in the range of 0.1 to $1 \mathrm{ft} / \mathrm{d}$, and the hydraulic conductivity computed from aquifer tests at saline wells in that zone is an order of magnitude higher. This ratio of hydraulic conductivity of the matrix (log and core-plug measurements) to fieldscale aquifer-test hydraulic conductivity indicates that conduit flow probably is appreciable in the transition zone but is not as dominant as it is in many parts of the freshwater zone (Hovorka and others, 1998). However, the absence of major known saline-water discharge areas might limit flow and conduit development in the transition zone.

\section{Recharge}

The Edwards aquifer is recharged through (1) seepage losses from surface streams that drain the Hill Country, where the streams flow onto the outcrop of the Edwards aquifer, (2) infiltration of rainfall on the outcrop, (3) subsurface inflow across the updip margin of the Balcones fault zone, where the Trinity aquifer is laterally adjacent to the downfaulted Edwards 


\section{Conceptualization and Simulation of the Edwards Aquifer, San Antonio Region, Texas}

aquifer (LBG-Guyton Associates, 1995), and (4) movement of water from the Trinity aquifer, where it underlies the Edwards aquifer, into the Edwards aquifer. The primary source of recharge is seepage from streams crossing the outcrop (hence, the outcrop is synonymous with the recharge zone). The headwater stream basins compose the catchment area and recharge zone (fig. 2). Major streams that cross the recharge zone of the San Antonio segment of the Edwards aquifer are the West Nueces, Nueces, Dry Frio, Frio, Sabinal, Medina, Guadalupe, and Blanco Rivers, and Seco, Hondo, Verde, Salado, Cibolo, Dry Comal, and Purgatory Creeks. Five major creeks (Barton, Williamson, Slaughter, Bear, and Onion) provide most of the recharge in the Barton Springs segment of the aquifer. The streams gain water as they flow over low-permeability Glen Rose Limestone, which is at the surface over most of the catchment area. The recharge zone essentially coincides with the outcrop area of the Edwards aquifer. Streams, other than the Guadalupe River, become predominantly losing streams as they cross the outcrop. Reported percentages of the total recharge that occurs as infiltration in interstream areas, rather than in streambeds, are (1) 15 percent for the Barton Springs segment of the Edwards aquifer (Slade and others, 1985; Scanlon and others, 2002) and (2) 20 percent (Klemt and others, 1979; Thorkildsen and McElhaney, 1992) and 40 percent (Maclay and Land, 1988) for the San Antonio segment.

Karst features and faults provide pathways for water to move from stream channels to the water table of the unconfined Edwards aquifer. Here, the water table is at depths generally greater than $100 \mathrm{ft}$ below the streambeds. All of the base flow and some of the storm runoff of streams crossing the recharge zone infiltrate to the unconfined aquifer. All major streams that cross the recharge area, except the Guadalupe River, lose water to the Edwards aquifer. The Guadalupe River both gains water from and loses water to the aquifer as it crosses the recharge zone and probably does not contribute appreciable recharge. Estimates of the combined recharge to the San Antonio segment of the Edwards aquifer from stream seepage and infiltration of rainfall range from a low of 43,700 acre-feet (acre-ft) during 1956 to a high of 2,486,000 acre-ft during 1992 (Hamilton and others, 2003). The long-term (1934-2002) mean annual recharge to the Edwards aquifer is 698,930 acre- $\mathrm{ft}$ (median 557,800 acre-ft) and for 1993-2002, is 794,070 acre-ft (median 576,300 acre-ft) (Hamilton and others, 2003). The five basins west of and including the Medina River Basin (fig. 2) supply most (about 70 percent) of the total recharge to the San Antonio segment of the Edwards aquifer (Burchett and others, 1986). Based on 1934-2000 streamflow data, streams west of the Medina River (in the Nueces River Basin) lose about 65 percent of their flow to the aquifer in the recharge zone. Much of the annual flow of the Medina River is impounded in Medina Lake (U.S. Army Corps of Engineers, 1965). Of the volume impounded, about one-half seeps into the Edwards aquifer from the lake and its irrigation facilities (U.S. Army Corps of Engineers, 1965).

Monthly rates of recharge for the San Antonio segment of the Edwards aquifer from seepage losses from streams and infil- tration of rainfall in the recharge zone are computed from records of streamflow-gaging stations near upstream and downstream limits of the recharge area and from estimated runoff in the recharge area (Puente, 1978). Recharge by seepage losses from streams in the drainage area of a losing stream is computed by subtracting the flow at the downstream station from the sum of the flow at the upstream station and estimated inflow from adjacent interstream areas. Recharge by infiltration of rainfall is estimated on the basis of unit runoff from the catchment area (Puente, 1978). Although streamflow data are available for most basins in the recharge area, about 30 percent of the total recharge area is ungaged because suitable sites for gaging stations are unavailable (Maclay, 1995). The rate of recharge in the ungaged areas is estimated by assuming that the runoff characteristics of the ungaged areas are similar to those of adjacent gaged areas (Puente, 1978). Evapotranspiration losses are assumed negligible in the recharge area. Annual recharge estimates computed by the USGS method, by basin (fig. 2), for the San Antonio segment of the Edwards aquifer for 1934-2003 (Slattery, 2004) are shown in figure 11.

The estimates of recharge for the Cibolo Creek and Dry Comal Creek Basins might be too high. Much of the stream channel for Cibolo Creek between the streamflow-gaging stations used to estimate the leakage from Cibolo Creek to the underlying aquifer lies within the Trinity aquifer outcrop area. Recent unpublished work indicates that only 40 to 50 percent of the stream channel for Cibolo Creek between the gaging stations might be within the Edwards aquifer outcrop area (Darwin Ockerman, U.S. Geological Survey, written commun., 2002). For the area along Cibolo Creek in the catchment area east of Boerne, karst-enhanced recharge is appreciable (Ashworth, 1983; Veni, 1994; Mace and others, 2000). The subsurface flow paths of this recharge are uncertain, however. LBG-Guyton Associates (1995) indicated that some of the recharge is diverted through cave conduits to the Guadalupe River. Therefore, large streamflow losses in Cibolo Creek in the catchment area east of Boerne used to compute Edwards aquifer recharge might only contribute to the Edwards aquifer in the Guadalupe River Basin, if at all. In contrast, some investigators indicate that much of the recharge is quickly transmitted to the Edwards aquifer (Veni, 1994; Barker and Ardis, 1996).

Estimates of annual recharge to the San Antonio segment of the Edwards aquifer for the nine major basins (fig. 2) were computed for the 56-year period 1934 through 1989 by HDR Engineering, Inc., and Geraghty and Miller, Inc. (1991) and by HDR Engineering, Inc., and Espey, Huston \& Associates, Inc. (1993) (hereinafter, HDR). HDR indicated that, compared with their method of computing recharge, the USGS method of computing recharge yields similar estimates in dry years, although recharge might tend to be underestimated in dry years. However, in wet years, the USGS method yields appreciably larger estimates than the HDR method. For example, for the period 1971-89, a period wetter than normal, the average annual recharge computed by the USGS for the Nueces River Basin was 26.2 percent higher than that computed by HDR. The differences between the HDR recharge estimates and the USGS 


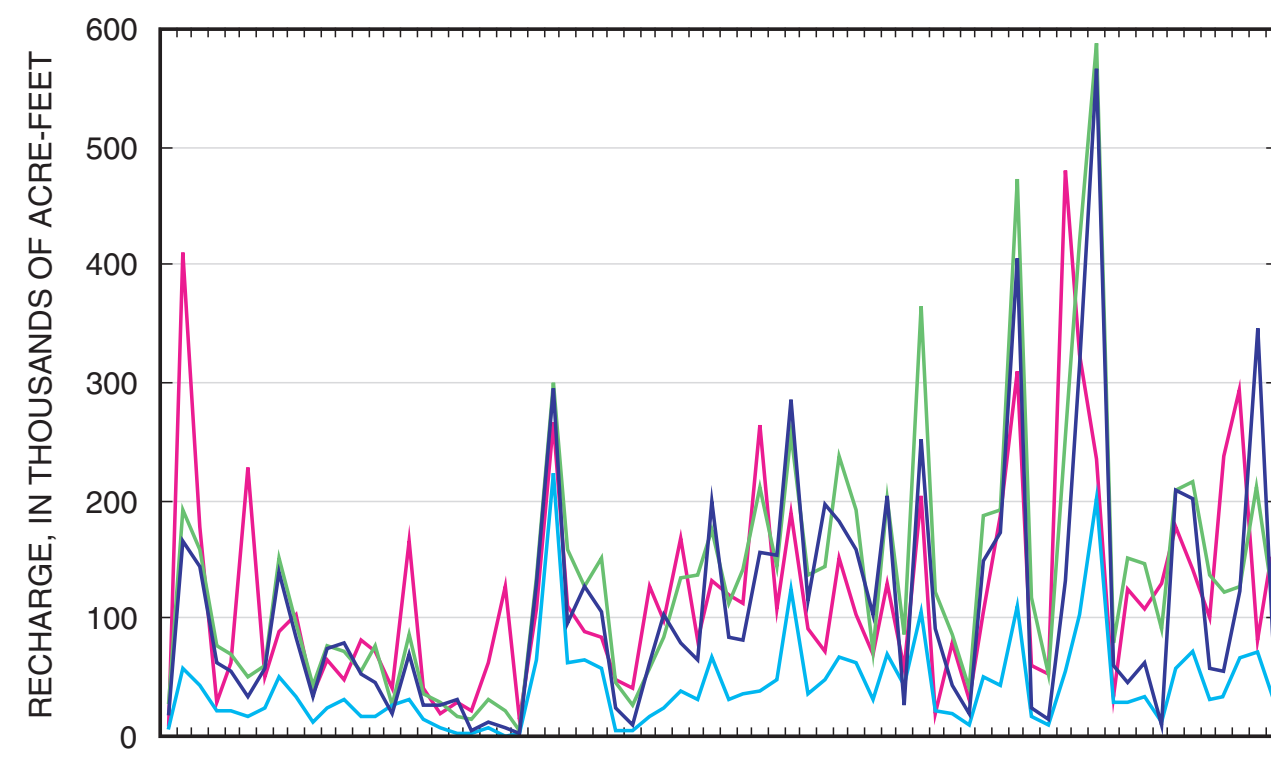

\section{EXPLANATION}

Basin or area

Nueces-West Nueces River Basin

Frio-Dry Frio River Basin

- Sabinal River Basin

Area between Sabinal and Medina River Basins

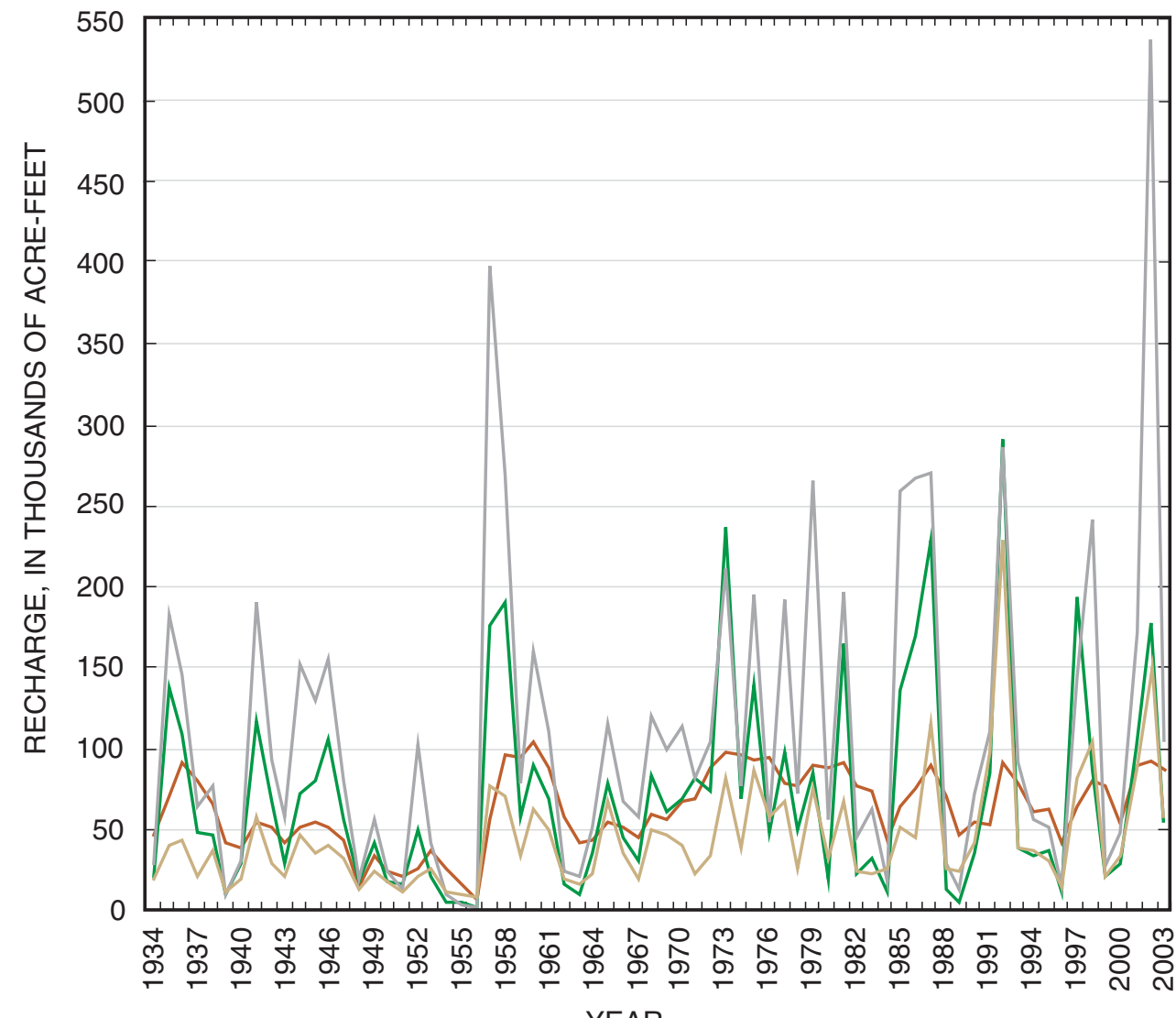

\section{EXPLANATION}

Basin or area

Medina River Basin

Area between Medina River Basin and Cibolo-Dry Comal Creek Basins

Cibolo Creek and Dry Comal Creek Basin

Blanco River Basin

(Note: Recharge from Guadalupe River Basin assumed negligible.)

Figure 11. Estimated annual recharge (from seepage losses from streams and infiltration of rainfall) to the San Antonio segment of the Edwards aquifer, San Antonio region, Texas, by recharge basin or contributing drainage area, 1934-2003 (Slattery, 2004).

recharge estimates are attributed to the manner in which potential runoff directly over the recharge zone and recharge from infiltration are estimated.

Despite generally larger USGS estimates than those of HDR for wet years for the period 1934-89, average annual
USGS estimates for some basins were less than those of HDR: For the Guadalupe River Basin, USGS estimated negligible recharge, whereas HDR estimated 11,255 acre-ft. For the Blanco River Basin, the USGS annual average was about 42 percent less than the HDR annual average. For the entire San 
Antonio segment of the aquifer for 1934-89, the average annual USGS estimate $(628,000$ acre-ft) was about 2 percent less than the average annual HDR estimate $(642,000$ acre-ft).

HDR Engineering, Inc. (1998) also estimated recharge to the San Antonio segment of the aquifer for the period 1990-96 and compared the estimates to the corresponding USGS estimates. The results and conclusions were similar to those for the 1934-89 period.

Estimation of recharge for the Barton Springs segment of the Edwards aquifer was described in detail by Barrett and Charbeneau (1996) and Slade and others (1985). Recharge was computed by subtracting streamflow downstream from the recharge zone from that upstream from the recharge zone. Threshold values of maximum recharge were determined by Slade and others (1985). Once recharge equaled the threshold value, recharge was assumed constant at that value, independent of increases in streamflow. Barrett and Charbeneau (1996) estimated recharge using data from 1979 through 1995. These recharge computations were extended through December 1998 by Scanlon and others (2002). Surface runoff from interstream areas to streams in the recharge zone was ignored in the recharge computations because such runoff generally only occurs during very large storms, when recharge already is maximum. Diffuse interstream recharge from infiltration of rainfall was assumed to equal 15 percent of total recharge (Scanlon and others, 2002).

The Edwards aquifer in much of the Balcones fault zone is juxtaposed against the Trinity aquifer both at the surface and at depth, and the Trinity aquifer likely discharges directly into the Edwards aquifer. Stein (1993) pointed out that cave development in the Edwards aquifer recharge zone can create conduits between the Edwards aquifer and the Trinity aquifer. The volume of water that moves laterally from the Trinity aquifer into the Edwards aquifer currently (2004) cannot be measured. A number of studies have shown, either through hydraulic or chemical analyses, that ground water likely flows from the Trinity aquifer into the Edwards aquifer (Long, 1962; Klemt and others, 1979; Walker, 1979; Senger and Kreitler, 1984; Slade and others, 1985; Maclay and Land, 1988; Waterreus, 1992; Veni, 1994, 1995). Mace and others (2000) indicated that ground water from the Trinity aquifer discharges to the south and east in the direction of the Edwards aquifer, with part of this ground water moving into the Edwards aquifer through faults, and part continuing to flow in the Trinity aquifer beneath the Edwards aquifer. They further indicated that ground water that continues to flow in the Trinity aquifer beneath the Edwards aquifer eventually discharges upward to the Edwards aquifer. The model developed by Kuniansky and Holligan (1994) directs all of the flow from the Trinity aquifer into the Edwards aquifer. The Glen Rose Limestone, although considered the uppermost unit of the Trinity aquifer, could be viewed as a part of the Edwards aquifer in the Cibolo Creek area because of the hydraulic response and continuity of the formations (Pearson and others, 1975; Veni, 1994, 1995).

The volume of flow from the Trinity aquifer into the Edwards aquifer only can be estimated. The available estimates vary. Lowry (1955) attributed a 5-percent error between measured inflows and outflows in the Edwards aquifer to flow from the Trinity aquifer. Woodruff and Abbott (1986) reported that recharge from Trinity aquifer inflow is 6 percent of total recharge (about 41,000 acre-feet per year [acre-ft/yr] on average) to the Edwards aquifer. LBG-Guyton Associates (1995) estimated an approximate range of Trinity aquifer underflow to the Edwards aquifer in the San Antonio region, excluding the Cibolo Creek contribution, of about 2,700 to 11,400 acre-ft/yr, representing about 2 percent of total average annual recharge to the Edwards aquifer.

Kuniansky and Holligan (1994) reported a flow of about 360,000 acre-ft/yr from the Trinity aquifer to the Edwards aquifer on the basis of modeling analysis, representing about 53 percent of the average annual recharge to the Edwards aquifer. Mace and others (2000) indicated that this estimate probably is too high. A flow of about 64,000 acre-ft/yr from the upper and middle zones of the Trinity aquifer in the direction of the Edwards aquifer, representing about 9 percent of the average estimated annual recharge to the Edwards aquifer, was simulated by Mace and others (2000). The average simulated flow across the southern and eastern Trinity aquifer model boundaries of Mace and others (2000) was about 500 acre-feet per year per mile [(acre-ft/yr)/mi]. The model indicated that this cross-boundary flow is much less for Travis and Hays Counties [310 (acre-ft/yr)/mi] than for Comal and Bexar Counties [660 (acre-ft/yr)/mi] and Medina County [500 (acre-ft/yr)/mi]. Faults have greater displacements to the east and therefore might be more effective barriers to flow (Mace and others, 2000). None of the previous numerical ground-water-flow models of the Edwards aquifer (Klemt and others, 1979; Slade and others, 1985; Maclay and Land, 1988; Wanakule and Anaya, 1993; Barrett and Charbeneau, 1996; Scanlon and others, 2002) included inflow from the Trinity aquifer.

\section{Discharge}

Most discharge from the Edwards aquifer occurs as (1) withdrawals by industrial, irrigation, and public-supply wells, and (2) springflow. Ground-water withdrawals by wells have increased with increasing population. From 1934 through 2002, the lowest estimated annual pumpage (withdrawals) for the San Antonio segment of the Edwards aquifer was 101,900 acre-ft in 1934 and the highest was 542,400 acre-ft in 1989 (Hamilton and others, 2003), as population in Bexar County increased from 292,500 in 1939 to 1,392,900 in 2000 (San Antonio Water System, 2000). Springflow from the San Antonio segment averaged 372,200 acre-ft/yr (median 375,800 acre$\mathrm{ft} / \mathrm{yr}$ ) for 1934-2002 (Hamilton and others, 2003). Total annual springflow from the Edwards aquifer has varied as much as an order of magnitude over the period of record. Springflow from the San Antonio segment totaled 69,800 acre-ft in 1956 during the 1950s drought and reached a record high of 802,800 acre-ft in 1992 (Hamilton and others, 2003). 
Locally, fracture systems might connect the Edwards aquifer to overlying units, which could provide paths for upward leakage where head gradients are upward; however, such flow is assumed to be negligible for the purposes of this report. Undetermined amounts of fresh ground water might discharge to the saline-water zone (Schultz, 1992, 1993, 1994; Maclay, 1995); however, those losses also are assumed to be negligible.

Water also discharges from the Edwards aquifer to the Leona River floodplain in south-central Uvalde County. The Leona River floodplain consists of relatively thick sediments (as much as 70 to $80 \mathrm{ft}$ ) that contain sand and gravel paleostreambed deposits (Green, 2004). The discharge occurs to the Leona River floodplain and becomes a combination of surface flow in the Leona River and subsurface flow in the sand and gravel deposits. Green (2004) estimated that as much as $100,000 \mathrm{acre}-\mathrm{ft} / \mathrm{yr}$ is discharged from the Edwards aquifer to the Leona River floodplain, about 13 percent of which becomes surface flow in the Leona River and about 87 percent subsurface flow in the sand and gravel deposits. Part of the subsurface flow ultimately discharges to Leona Springs.

Annual total discharge from the San Antonio segment generally has increased since the mid-to-late 1960s. This increase largely results from an approximate doubling of the well withdrawals. Springflow also has increased, exceeding the longterm average annual springflow (372,200 acre-ft) in most years since the late 1960s. The increases in springflow are the result of greater-than-average recharge during most years since the late 1960s.

\section{Withdrawals by Wells}

Thousands of water wells tap the Edwards aquifer in the San Antonio region. Annual withdrawals by wells in the San Antonio segment of the aquifer (fig. 12a) increased steadily at an average annual rate of about 4,500 acre-ft/yr, more than tripling between 1939 and 2000. Municipal, irrigation, and industrial water use (fig. 12b) make up more than 95 percent of annual withdrawals from the Edwards aquifer in each county except for Comal County, where mining also accounts for appreciable withdrawals. In Bexar, Hays, Kinney, and Travis Counties, municipal water withdrawals account for more than 85 percent of annual withdrawals. Irrigation accounts for more than 60 percent of withdrawals in Uvalde County and more than 80 percent in Medina County. Bexar and Uvalde Counties are the largest producers of ground water from the Edwards aquifer in the San Antonio region (fig. 12c). The annual number of new wells constructed is increasing, primarily because of increasing population. The bulk of withdrawals for irrigation occur in Uvalde and Medina Counties (fig. 13a). Withdrawals are concentrated in the confined part of the Edwards aquifer, with the largest withdrawals in and around San Antonio and near Uvalde and close to the downdip limit of the freshwater zone (fig. 13b).

In the Barton Springs segment of the Edwards aquifer, annual withdrawals ranged from about $2,800(1990,1991)$ to 4,300 acre-ft (1998) during 1989-98, with the number of reported users ranging from 100 in 1989 to 142 in 1998
(Scanlon and others, 2002). The years with lowest withdrawals correspond to years with highest rainfall. Annual withdrawals ranged from 3 percent $(1991,1992)$ to 138 percent (1996) of recharge (Scanlon and others, 2002, table 4).

Yields of more than 1,000 gal/min are common for wells in the confined freshwater zone of the Edwards aquifer. Yields of wells commonly are limited more by the capacity of the pumps to discharge water than by the productivity of the aquifer. The density of wells in the unconfined recharge zone of the aquifer is substantially less than that in the confined zone, and typically the yields are smaller. The smaller yields are the result of generally less saturated thickness and hydraulic conductivity in the unconfined zone. In the transition zone of the aquifer, wells usually flow at the land surface at rates ranging from less than 100 to several hundred gallons per minute (Maclay, 1995).

The USGS maintains records of annual withdrawals by wells used for public supply, irrigation, and industrial use. Withdrawals for public supply generally are metered. The withdrawals from most irrigation wells are estimated from county tax rolls and irrigated acreage by crop type. The EAA initiated the Edwards Aquifer Well Metering Program in 1997, requiring meters for all municipal, industrial, and irrigation wells in the Edwards aquifer (Hamilton and others, 2003). Withdrawal data from the Well Metering Program has been used by EAA to estimate well discharge since 1998. Military and industrial facilities also provide records of withdrawals. Withdrawal data also are available from the TWDB. Monthly withdrawal data for the Barton Springs segment of the Edwards aquifer are collected by the Barton Springs/Edwards Aquifer Conservation District and are available from 1989 through the present.

\section{Springflow}

Springs and seeps are the major natural discharge outlets for the Edwards aquifer, accounting for nearly all natural discharge from the aquifer. Comal and San Marcos Springs are the largest springs, with total discharges of 274,800 and 195,900 acre-ft, respectively, in 2002, which translates to flow rates of 380 and 271 cubic feet per second $\left(\mathrm{ft}^{3} / \mathrm{s}\right)$, respectively (Hamilton and others, 2003). Groschen (1996) postulated that the locations of most major springs in the Edwards aquifer are structurally controlled. Ground-water flow is diverted along barrier faults, with vertical openings at a few places along faults where springs can emerge. Water in the confined Edwards aquifer under sufficient pressure might rise to the surface through a natural break in the overlying confining beds. Faults that intersect the aquifer at depth provide a pathway for water to rise to the land surface. Structural constrictions also can facilitate the rise of water along faults. For example, the structural graben through which most of the flow to Comal Springs in Comal County occurs, pinches out, and ground water rises along the Comal Springs fault near the constriction (Maclay, 1995). Similarly, San Antonio and San Pedro Springs in Bexar County discharge ground water that rises along a major fault. A structural horst near the fault blocks ground-water flow in a complex 


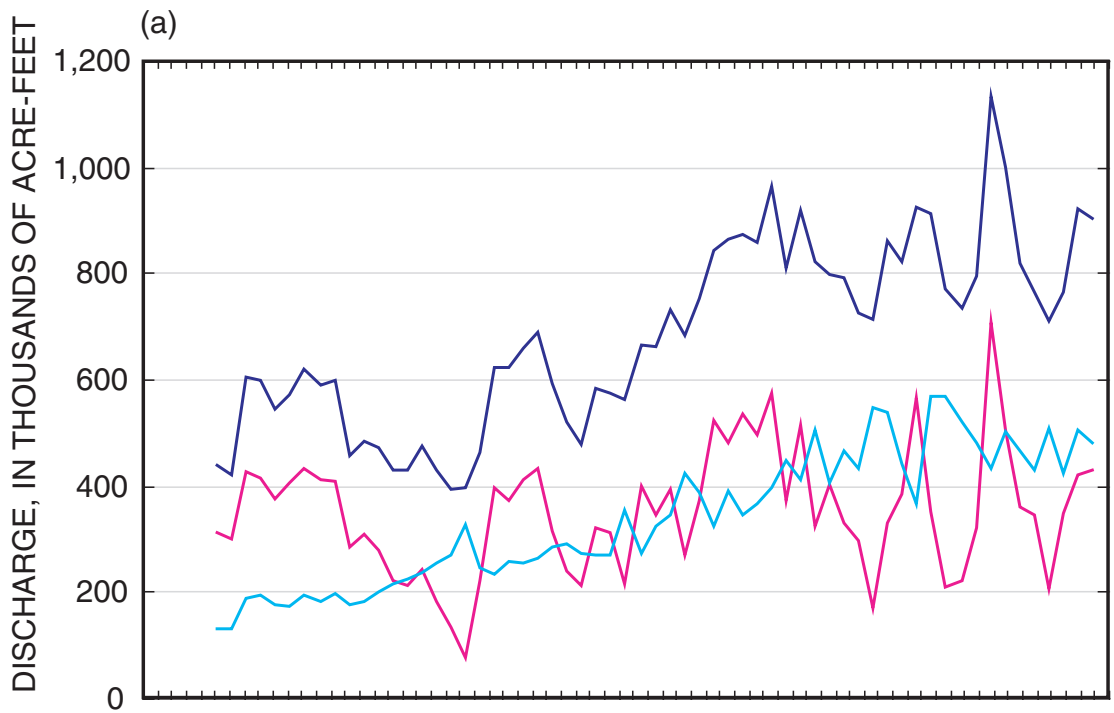

\section{EXPLANATION}

Annual discharge (Hamilton and others, 2003)

Annual springflow (C.L. Otero, U.S. Geological Survey, written commun., 2001)

Annual withdrawals-Computed as total discharge minus springflow

(b)

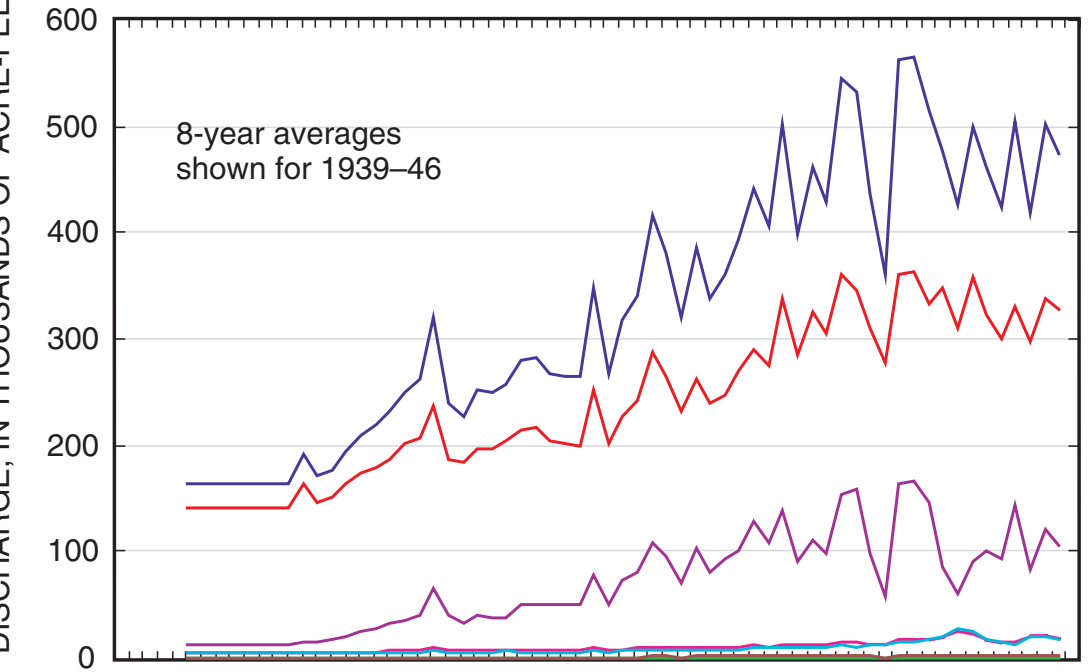

\section{EXPLANATION}

Annual withdrawals by water-use category (See text, p. 35, 56, 58)

Municipal Industria

Power

Mining

Irrigation

- Stock

Total

(c)

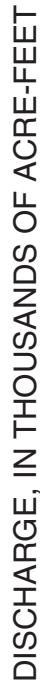

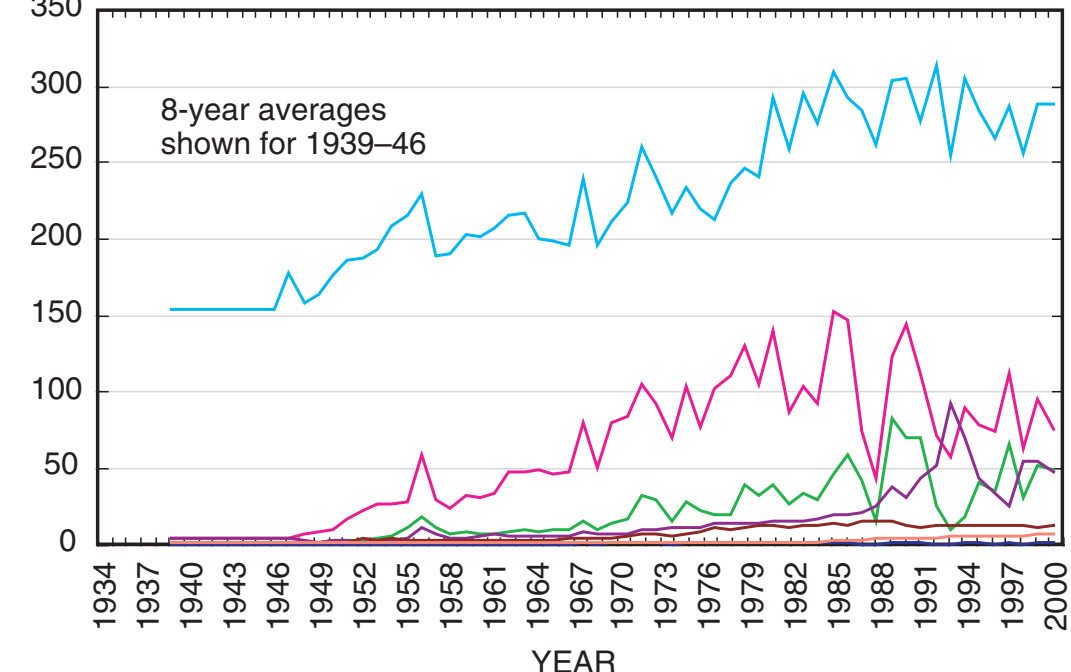

EXPLANATION

Annual withdrawals by county (See text, p. $35,56,58$ )

Kinny

Uvalde

Medina

Bexar

Comal

Hays

Travis

Figure 12. (a) Annual ground-water discharge, springflow, and withdrawals, (excluding Travis County); (b) annual withdrawals by water-use category (excluding Travis County); and (c) annual withdrawals by county, in the active model area of the Edwards aquifer, San Antonio region, Texas, 1939-2000. 


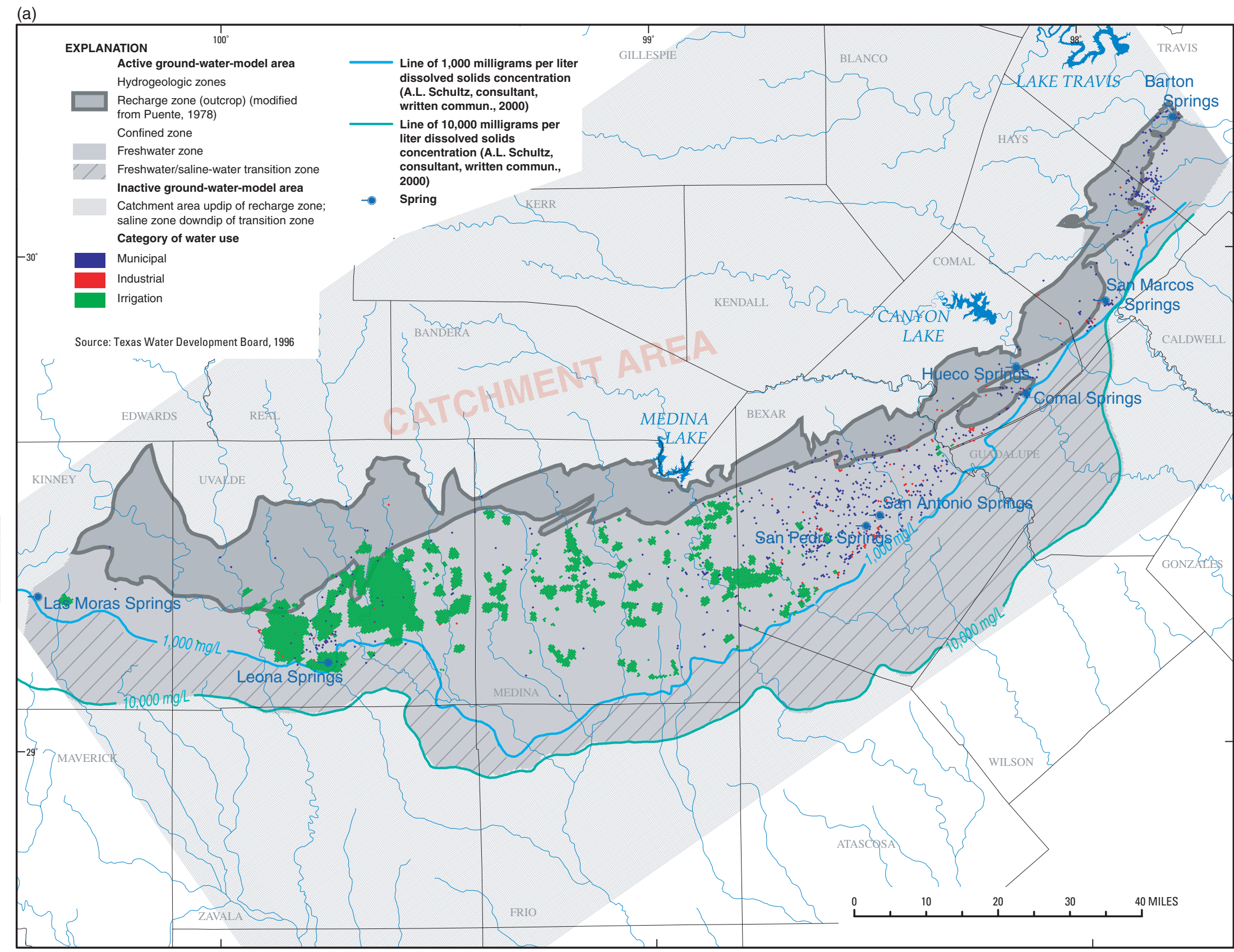


(b)

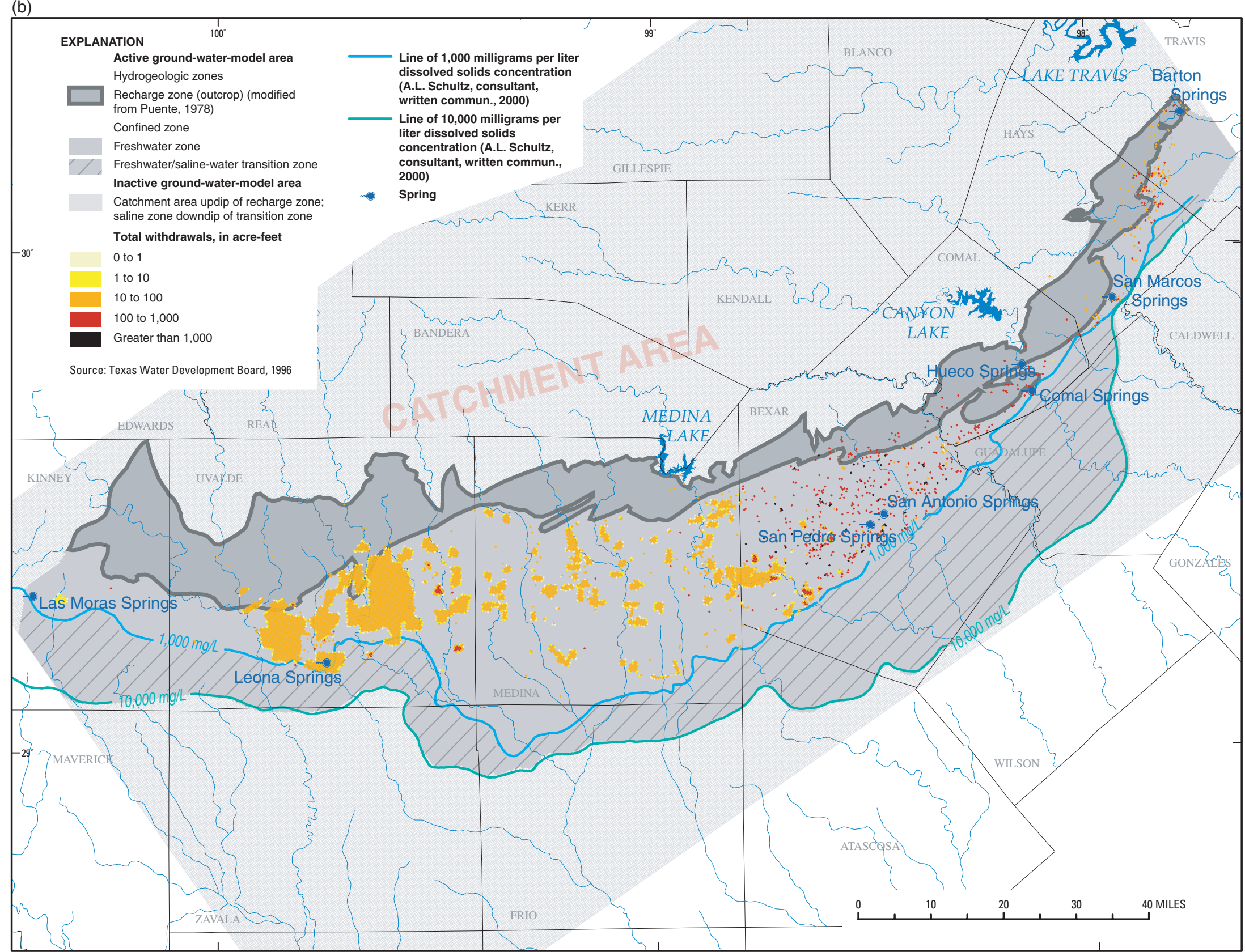

Figure 13b. Distributions of annual total withdrawals for the Edwards aquifer, San Antonio region, Texas, 1996. 


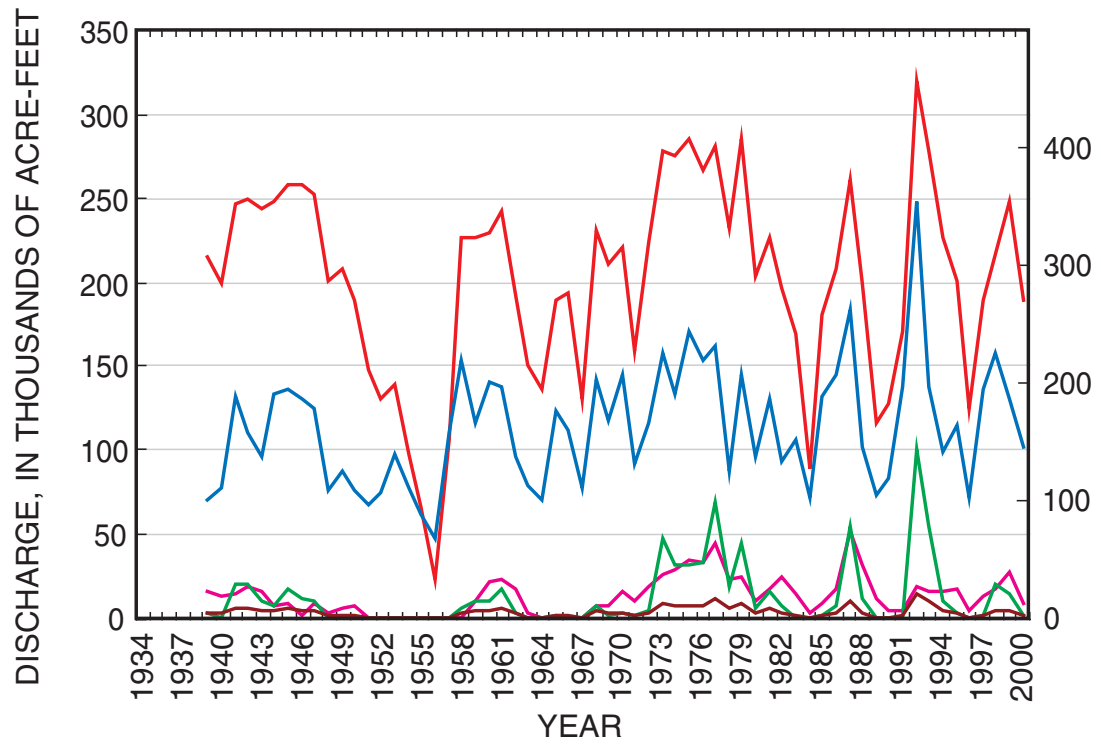

EXPLANATION

Springflow (C.L. Otero, U.S. Geological Survey, written commun., 2001)

- Comal

_ San Marcos

- Leona

- San Antonio

- San Pedro

Figure 14. Annual measured discharge for major springs in the San Antonio segment of the Edwards aquifer, San Antonio region, Texas, 1939-2000.

graben and diverts flow around its northern and southern margins, some of which emerges as springflow (Maclay, 1995).

Leona Springs consists of a number of seeps emerging from permeable gravel of the Leona Formation within the channel of the Leona River in Uvalde County. The gravel directly overlies the Edwards aquifer at some places or is hydraulically connected, by faults, to the confined Edwards aquifer (Maclay, 1995). Green (2004) indicated that the Leona Formation is juxtaposed with the Edwards Group at the location of the Leona River headwaters in the city of Uvalde, on the basis of geologic structural interpretation by Clark and Small (1997) and Clark (2003). This juxtaposition of the two formations provides a source of Edwards water for the Leona River floodplain and subsequent discharge to Leona Springs. Water rising from the Edwards aquifer discharges into the permeable gravel of the Leona River floodplain, and part of that subsurface flow discharges to Leona Springs. The altitude of the highest point of discharge from the Edwards aquifer to the gravel varies as the potentiometric surface of the Edwards aquifer rises and falls in the vicinity of springs. A substantial but unmeasured volume of discharge from the Edwards aquifer moves through the permeable gravel in the Leona River floodplain and discharges at other seeps in the gravel at lower altitudes. Leona Springs emerged because of a structural restriction in Uvalde County east of Uvalde and north of a structural horst in the Edwards aquifer, inhibiting the ability of the aquifer to transmit all of the flow from the west as subsurface flow to the east (Maclay, 1995). During periods of large recharge, water levels in the Edwards aquifer west of the restriction rise rapidly to land surface, resulting in large springflows. Recent work indicates that discharge from Leona Springs might be much greater than the average annual discharge of about 12,970 acre- $\mathrm{ft}\left(18 \mathrm{ft}^{3} / \mathrm{s}\right)$ for 1939-2000 estimated by the USGS. Green (2004) estimated that about 87,000 acre-ft/yr of Edwards aquifer discharge becomes subsurface flow in the Leona River floodplain, and some percentage of that flow discharges at Leona Springs.

Annual springflow for Comal, San Marcos, Leona, San Antonio, and San Pedro Springs in the San Antonio segment of the Edwards aquifer is shown in figure 14. Increases in withdrawals upgradient from the springs have appreciably reduced the discharge at Comal Springs at times. The only period of zero flow at Comal Springs was from June 13, 1956, to November 4, 1956, near the end of the severe drought of the 1950s. During the period of zero springflow, scant recharge and increased withdrawals lowered hydraulic heads in the aquifer below the altitude of the spring orifice. Tritium studies by Pearson and others (1975) and time-series analysis of water properties and constituents by Rothermel and Ogden (1986) have demonstrated that Comal Springs receives little local recharge except during high-water-table conditions.

Hydrographs of Hueco and San Marcos Springs generally show the same periods of highs and lows as those shown for Comal Springs, but the flow at Hueco Springs tends to fluctuate more than at Comal Springs. Hueco Springs comprises a small group of springs and seeps near the Guadalupe River about $5 \mathrm{mi}$ north-northwest of Comal Springs. It is the only large spring (1945-73 average annual flow about $36 \mathrm{ft}^{3} / \mathrm{s}$ ) in the Edwards aquifer outcrop area and is believed to have a much smaller contributing area than any of the other major springs. Water-level fluctuations in wells just north of the Hueco Springs fault correlate more closely with the fluctuations in the discharge of Hueco Springs than with the discharges of Comal and San Marcos Springs. The smaller average discharge of Hueco Springs might also indicate that the contributing area for the spring is relatively small (Maclay, 1995). Water-chemistry data, water-temperature data, and samples for tritium analyses 
(U.S. Geological Survey, unpub. data, various years; William F. Guyton and Associates, 1979) also indicate a local source of water for some of the discharge from Hueco Springs. In addition, Ogden, Quick, and Rothermel (1986) indicated that Hueco Springs flow is composed of recent, locally derived recharge as demonstrated by dye-trace results, turbidity, and rapid fluctuations in water chemistry after storms. Hueco Springs does not flow during prolonged dry periods.

William F. Guyton and Associates (1979) considered the recharge area for Hueco Springs to comprise primarily the Dry Comal Creek Basin (fig. 2) northwest of Hueco Springs, the recharge area of the Guadalupe River Basin west of the river, and possibly the upper part of the recharge area of the Cibolo Creek Basin. Hueco Springs probably is the first outlet for a local recharge area to the north, west, and southwest of that spring, with the remainder of the water that enters the aquifer in the local recharge area moving across the Guadalupe River Basin to San Marcos Springs (William F. Guyton and Associates, 1979). As previously discussed, the subsurface flow paths of recharge entering the aquifer in the Cibolo Creek Basin are uncertain, and flow relations between the Edwards and Trinity aquifers in the area of Hueco Springs are complex. Based on hydraulic connection between the Trinity and Edwards aquifers in the recharge area in the Cibolo Creek Basin (LBG-Guyton Associates, 1995) and the potential juxtaposition of the aquifers along fault planes within the contributing area for the spring, an unknown percentage of the Hueco Springs flow might be derived from the Trinity aquifer.

San Marcos Springs discharges at altitudes that are appreciably lower than those of Comal Springs, and therefore is the "underflow" spring for the San Antonio segment of the Edwards aquifer. Ogden, Quick, and Rothermel (1986) reported that pressure-head distributions indicate the existence of two separate flow regimes, one of "older" water moving to the spring from the San Antonio region and the other of "younger" water moving to the spring from the Blanco River. Maclay (1995) concluded that most of the San Marcos Springs discharge might be derived from water entering the aquifer in the Cibolo Creek and Dry Comal Creek, Guadalupe River, and Blanco River Basins (fig. 2) north of Hueco Springs. On the basis of work by Puente (1976), the regional underflow component of springflow at San Marcos Springs ranges from 40 to 100 percent of total springflow on a monthly basis, and the local component of flow from the outcrop area ranges from 0 to 60 percent. During the drought of the 1950s, however, the monthly mean discharge from San Marcos Springs was sustained by about $60 \mathrm{ft}^{3} / \mathrm{s}$ of subsurface flow from the west, out of a confined part of the aquifer, rather than from the outcrop area (Puente, 1976).

Increased withdrawals, primarily from wells in San Antonio, has resulted in frequent periods of zero discharge from San Antonio and San Pedro Springs (Brune, 1975). San Antonio Springs has flowed intermittently since 1950-but only during periods of relatively high water levels. The USGS has established relations between springflows for San Antonio and San Pedro Springs and water levels in the Bexar County index well
(J-17, TWDB well 6837203, pl. 1), necessitated by gaps in the record of discharge measurements for these springs (G.B. Ozuna, U.S. Geological Survey, written commun., 2001). The relations indicate that zero discharge occurs at San Antonio Springs when water levels in the Bexar County index well are below $669.9 \mathrm{ft}$ above NGVD 29, whereas zero discharge occurs at San Pedro Springs when water levels in the Bexar County index well are below $651.7 \mathrm{ft}$ above NGVD 29. Periods of zero discharge have been appreciably more frequent and of longer duration for San Antonio Springs than for San Pedro Springs. Extended periods of zero discharge for San Antonio Springs include June 1949 to February 1958, June 1962 to April 1965, July 1965 to December 1967, July 1982 to October 1985, June 1988 to November 1991, and May 1995 to May 1997. In contrast, the only extended period of zero discharge lasting more than 1 year for San Pedro Springs was July 1951 to October 1957. Other periods of zero springflow for San Pedro Springs that lasted 3 to 9 months occurred in 1963, 1964, 1967, 1971, 1984, 1989, 1990, 1991, and 1996. However, the discharge from San Antonio Springs typically is much greater than for San Pedro Springs, for example, 58,600 acre-ft $\left(81 \mathrm{ft}^{3} / \mathrm{s}\right)$ for San Antonio Springs compared to 10,000 acre- $\mathrm{ft}\left(14 \mathrm{ft}^{3} / \mathrm{s}\right)$ for San Pedro Springs in 2002. The more frequent and longer duration periods of zero discharge combined with greater magnitudes of discharge for San Antonio Springs relative to San Pedro Springs reflect the larger discharge capacity and higher spring orifice altitude for San Antonio Springs.

In the Barton Springs segment of the Edwards aquifer, ground-water discharge occurs primarily at Barton Springs, which consists of a series of springs in the Barton Springs Pool area in Barton Creek close to where it enters the Colorado River. Long-term (1918-99) average annual discharge at Barton Springs is $53 \mathrm{ft}^{3} / \mathrm{s}$. Cold Springs, about 0.4 mi northwest of Barton Springs, discharges to the Colorado River but is not gaged because it is flooded by the river. Scanlon and others (2002) estimate that discharge at Cold Springs is about 25 percent of that at Barton Springs on the basis of the most accurate total measurement of flow at Cold Springs; but discharge might be as little as 4 percent of the discharge at Barton Springs on the basis of other, partial measurements for Cold Springs.

\section{Water-Level Fluctuations and Storage}

Water levels in the Edwards aquifer do not show a longterm decline as a result of ground-water withdrawals. The aquifer is dynamic, with water levels generally responding to temporal and spatial variations in recharge and ground-water withdrawals. During periods of drought, water levels decline but recover rapidly in response to recharge. Most of the ground water used for public supply is withdrawn near San Antonio, where water levels in the Bexar County index well (J-17, TWDB well 6837203) have varied between a low of $612.5 \mathrm{ft}$ above NGVD 29 in 1956 to a high of $703.3 \mathrm{ft}$ above NGVD 29 in 1992 (Hamilton and others, 2003). Although recurring droughts and floods have caused appreciable short-term 
fluctuations in water levels, long-term hydrographs (about 80 years) indicate no net decline (or rise) of water levels in the San Antonio area.

Long-term hydrographs of water levels in selected wells open to the Edwards aquifer show water-level trends for 19472000 that are strongly correlated to the climate (figs. 15-17). The locations of the wells with hydrographs are shown on plate 1. The drought of the early 1950 s is documented by the downward trends of water levels at these wells. The longest period of declining water levels was from 1947 to 1956. The lowest water levels were reached in August 1956, when water levels in the Bexar County index well (J-17, TWDB well 6837203) were below an altitude of $620 \mathrm{ft}$ for 4 months. The major storms of 1957 and 1958 and resulting above-average recharge to the aquifer caused large rises in water levels to altitudes about the same as the relatively high altitudes before the mid-1940s. The trend in recent years continues to follow a similar pattern that reflects differences in annual rates of recharge and discharge. However, greater amplitudes of water-level fluctuations in some wells began in the 1970s because of increased withdrawals in Bexar County. The hydrographs (figs. 15-17) indicate periods of rapid rises in water levels in 1957, 1973, 1981, 1987, 1991, 1992, and 1998. These rises in water levels reflect appreciable recharge that resulted from large amounts of rainfall in the catchment area and recharge zone. The highest water levels occurred in the early 1990s.

A variety of factors affect water-level fluctuations in wells, including number of fractures or conduits penetrated, or both, and location near major pumping centers. Minimal water-level fluctuations in a well might be attributable to proximity to a conduit. Large water-level fluctuations in wells open to the confined zone of the aquifer represent the movement of pressure pulses through the aquifer and indicate that the wells are hydraulically connected to the recharge zone. Generally, the amplitude of seasonal and short-term water-level fluctuations is greater in the recharge zone than in the confined zone. This is the result of a number of factors, including the proximity of the recharge, the local barrier faults that affect ground-water circulation, and the smaller transmissivity of the aquifer in the recharge zone (Maclay, 1995). Also, the amplitude of waterlevel changes tends to be less near the major springs in Uvalde, Comal, and Hays Counties, probably because of higher transmissivity near the springs.

In the Barton Springs segment of the Edwards aquifer, Slade and others (1985) noted that maximum water-level fluctuations range from 1 to $10 \mathrm{ft}$ in the western area, 10 to $50 \mathrm{ft}$ in the central area, and 40 to $119 \mathrm{ft}$ in the eastern area. The range in water levels in wells with the longest monitoring records reported by Scanlon and others (2002) was from 96 to $164 \mathrm{ft}$, with most of the monitoring wells showing large seasonal water-level fluctuations. Hauwert and Vickers (1994) noted rises of 10 to $20 \mathrm{ft}$ in a well in the confined zone of the aquifer in response to 1- to 2-in. rainfall amounts in early 1992. Senger and Kreitler (1984) indicated that water-level fluctuations in many of the wells in the confined zone of the aquifer correlated with variations in spring discharge.
Water-level fluctuations reflect changes in the amount of water in storage in the Edwards aquifer. The total volume in circulating water in the freshwater zone of the Edwards aquifer is equal to the volume of interconnected, drainable void space within the saturated thickness of the aquifer (Maclay, 1995). The effective porosity is the amount of interconnected pore space available for fluid transmission, expressed as a percentage of the total volume of the interconnected interstices (Lohman and others, 1972, p. 10). Major storage changes that occur when water levels in the aquifer decline or rise are largely dependent on the effective porosity of the unconfined zone of the Edwards aquifer. The effective porosity generally ranges from 2 to 14 percent (Maclay and Small, 1976); 6 percent is considered average (Maclay, 1995).

Average total porosity (porosity) through the thickness of the Edwards aquifer generally shows lateral gradational changes, from a minimum of 16 percent to a maximum of 28 percent in individual wells; interpolated average porosity of the aquifer is 18 percent (Hovorka and others, 1996). Hovorka and others (1996) estimated the total amount of water-filled pore space within the San Antonio segment of the Edwards aquifer to be 173 million acre-ft. Of this, 157 million acre- $\mathrm{ft}$ is in the confined zone and 16 million acre- $\mathrm{ft}$ is in the unconfined zone. Maclay (1989) estimated that 25 to 55 million acre-ft of water in the Edwards aquifer is circulating in pore space or drainable by gravity, which is substantially lower than the estimate of water in storage by Hovorka and others (1996). Using an effective porosity of 6 percent, Maclay (1995) computed the total volume of circulating freshwater in the San Antonio segment of the Edwards aquifer to be about 45 million acre- $\mathrm{ft}-38$ million acre- $\mathrm{ft}$ in the confined zone and 7 million acre- $\mathrm{ft}$ in the unconfined zone.

The total amount of stored water in the Edwards aquifer represents the long-term accumulation of the volumetric difference between recharge and discharge. Storage increases when recharge exceeds discharge and decreases when recharge is less than discharge. Under drought conditions, withdrawals and springflow can appreciably exceed recharge, thereby depleting water from storage. In 1956, when water levels were at historical lows, more than 2 million acre-ft of water had been removed from storage by the end of the drought of record when net discharge exceeded recharge (Garza, 1966). When discharge exceeds recharge and removes water from storage, water levels drop and the volume of springflow decreases. Withdrawals at rates that exceed annual recharge results in water-level declines, first by decreasing pressure in the confined zone and eventually, if the water level drops below the top of the aquifer, by draining porosity. The volume of water released for confined conditions (pressure change) is two to three orders of magnitude less than the volume that would be released from storage with a similar decline of water levels for unconfined conditions (pore drainage). Hovorka and others (1996) computed that a 100-ft change in water level over the entire confined zone of the San Antonio segment of the Edwards aquifer would yield only 33,400 acre$\mathrm{ft}$ of water. The fact that more than this amount of water is produced annually from the confined zone of the aquifer 
(a)
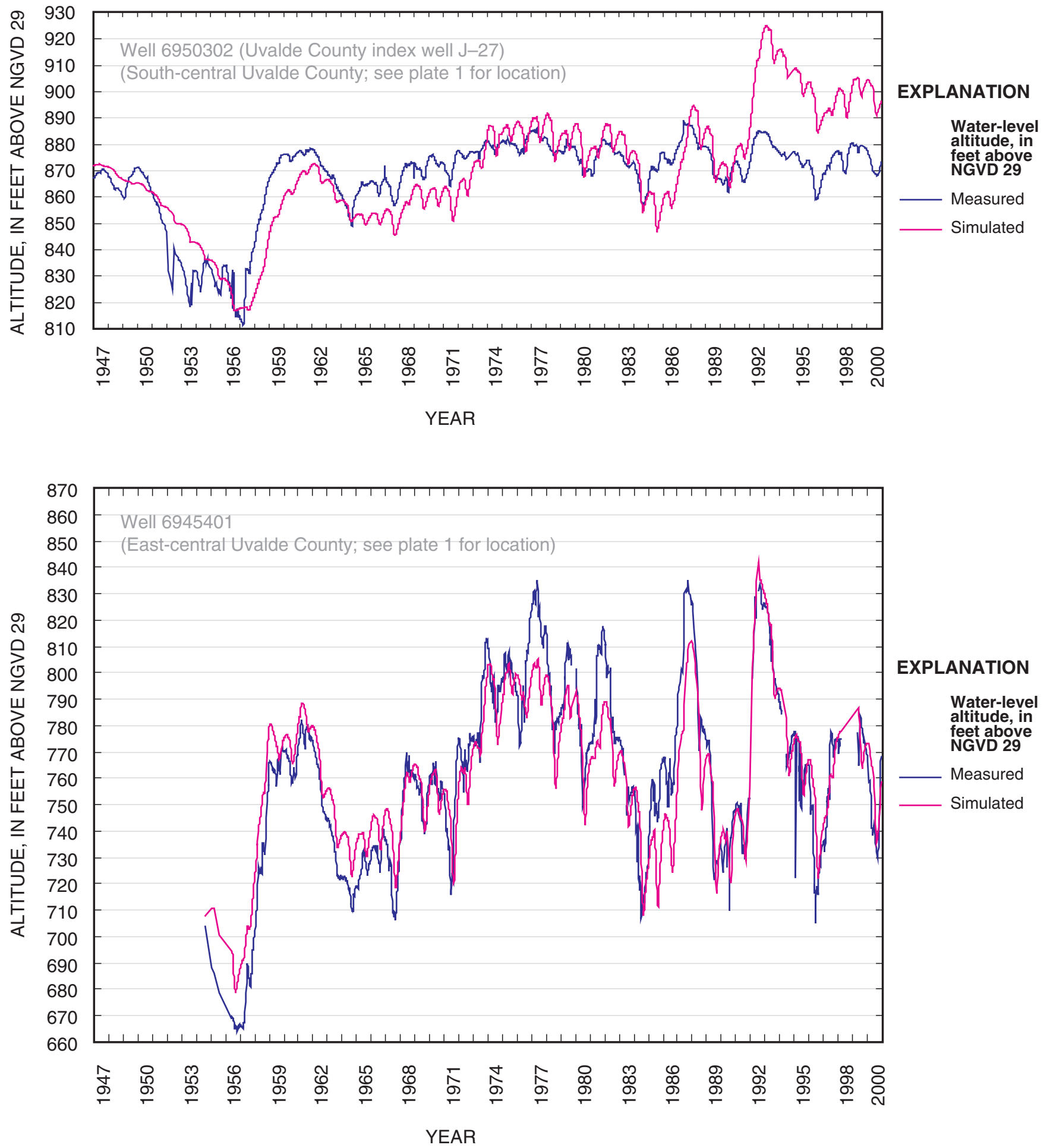

Figure 15a. Measured and simulated water levels (hydraulic heads) for Edwards aquifer wells in Uvalde County, San Antonio region, Texas. 
(b)
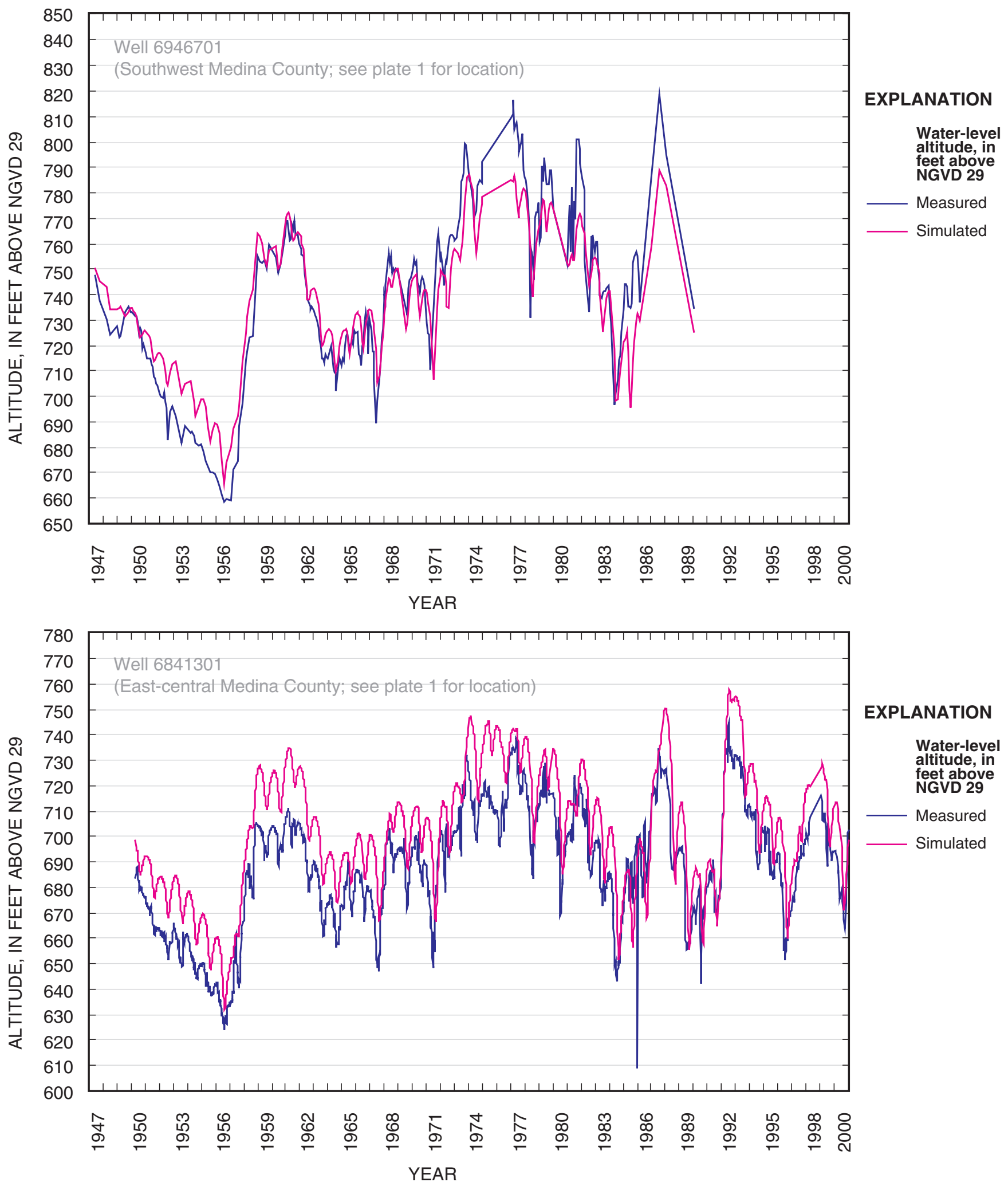

Figure 15b. Measured and simulated water levels (hydraulic heads) for Edwards aquifer wells in Medina County, San Antonio region, Texas. 


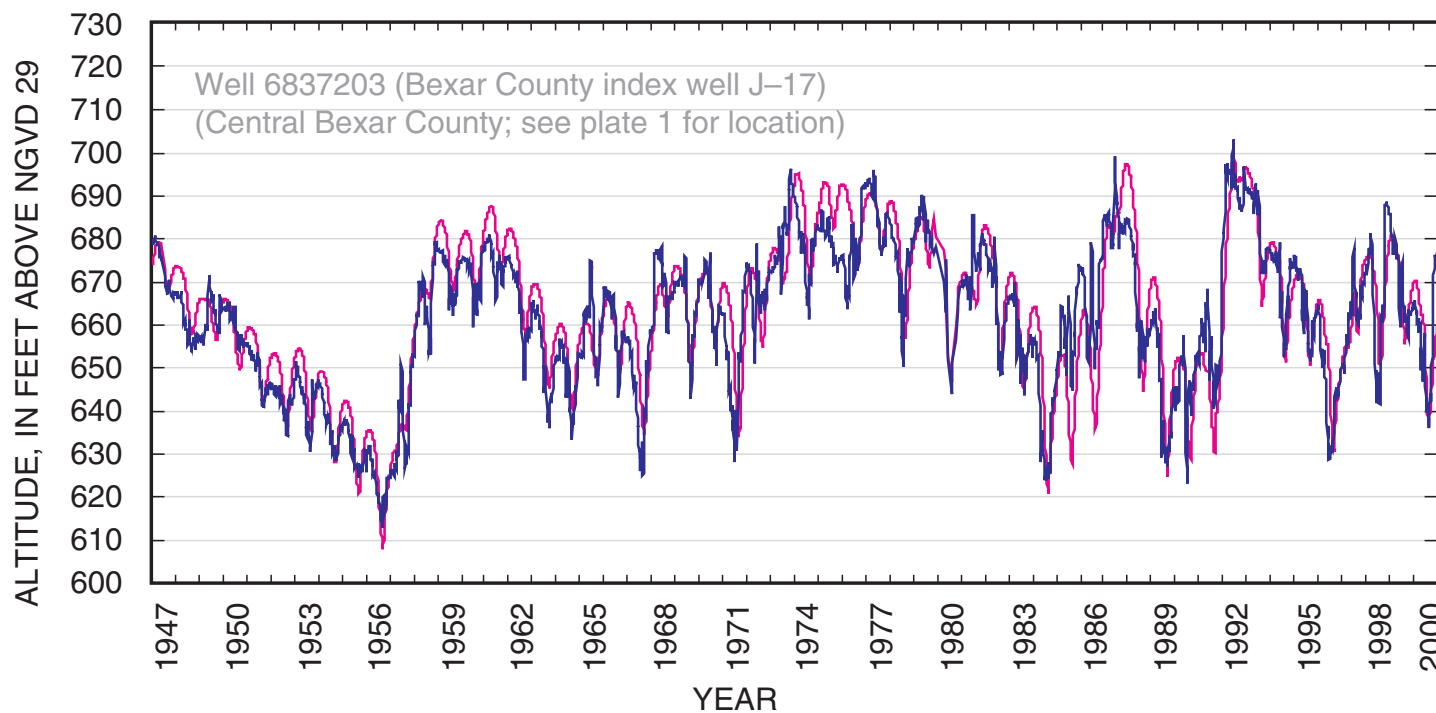

EXPLANATION

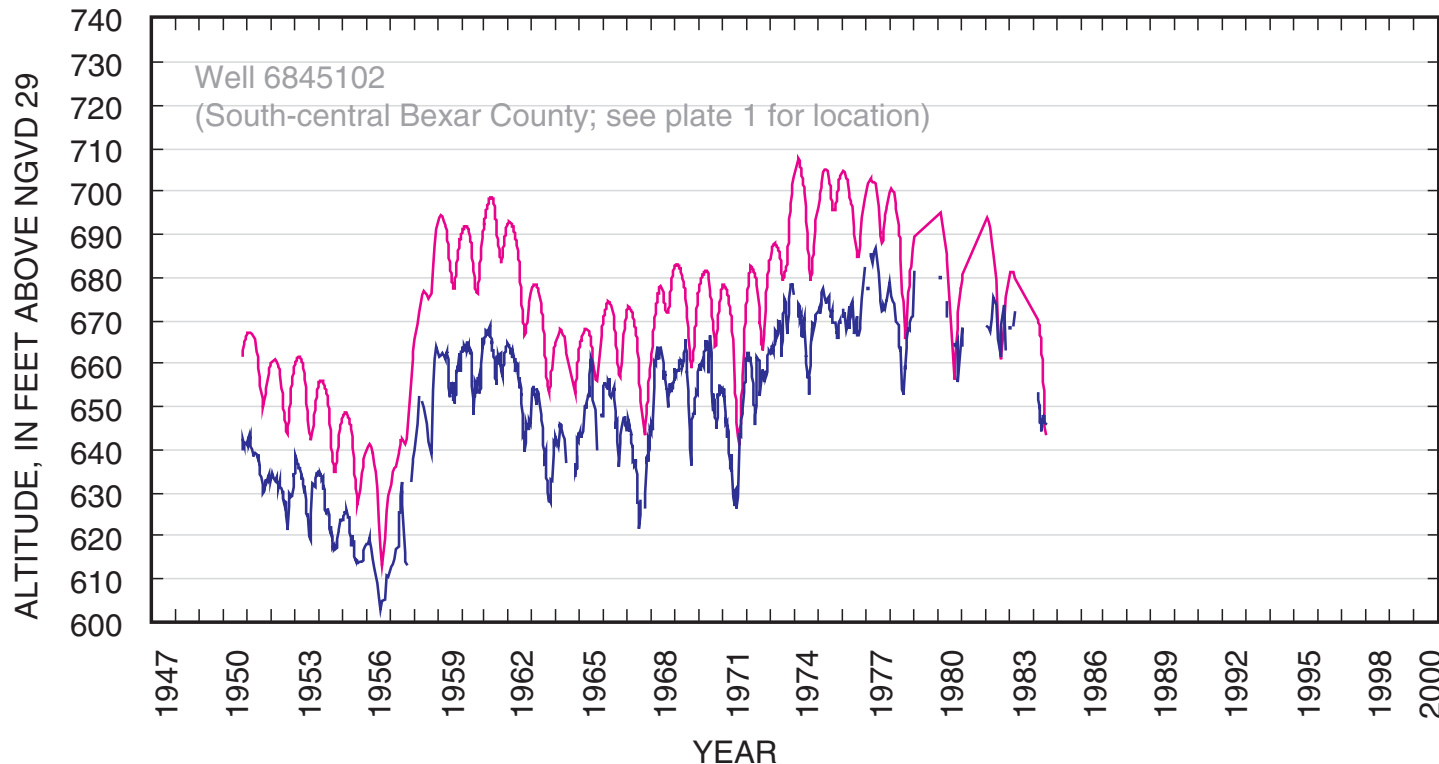

EXPLANATION

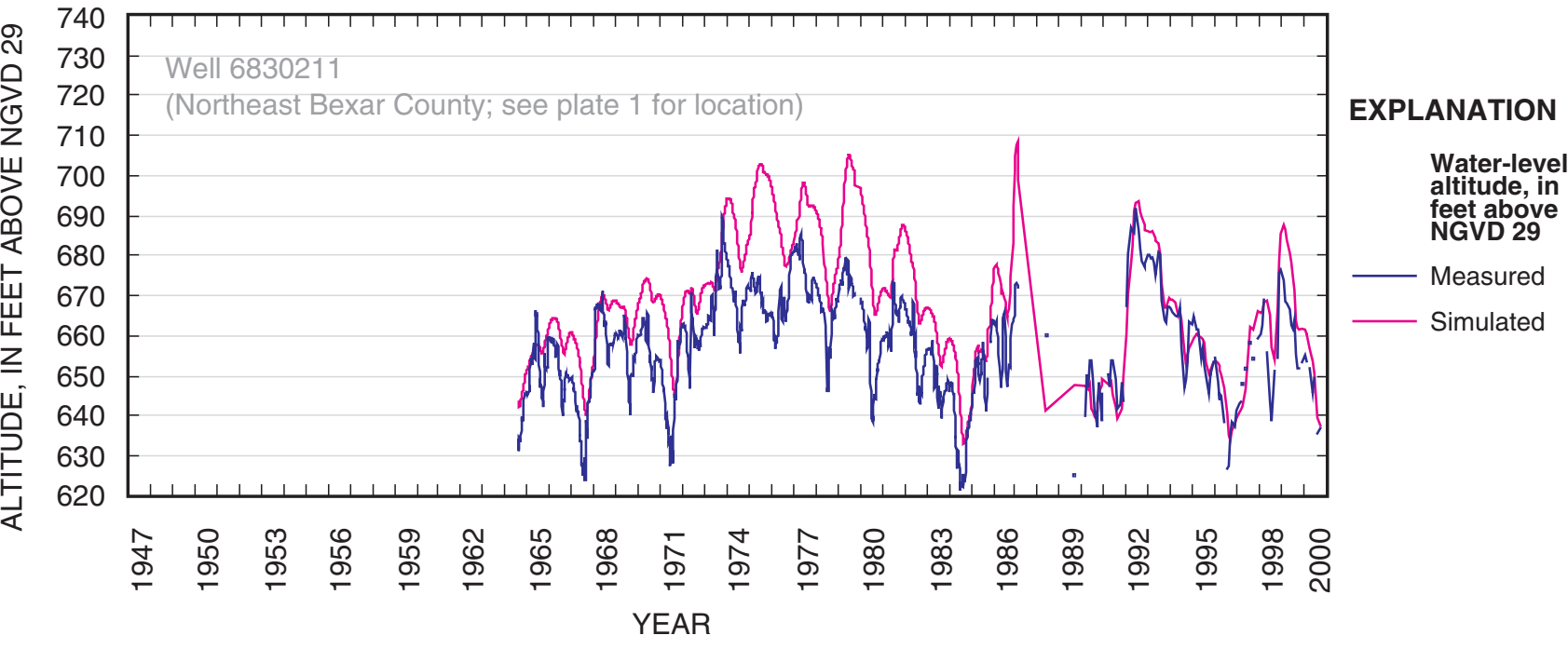

Figure 16. Measured and simulated water levels (hydraulic heads) for Edwards aquifer wells in Bexar County, San Antonio region, Texas. 
(a)
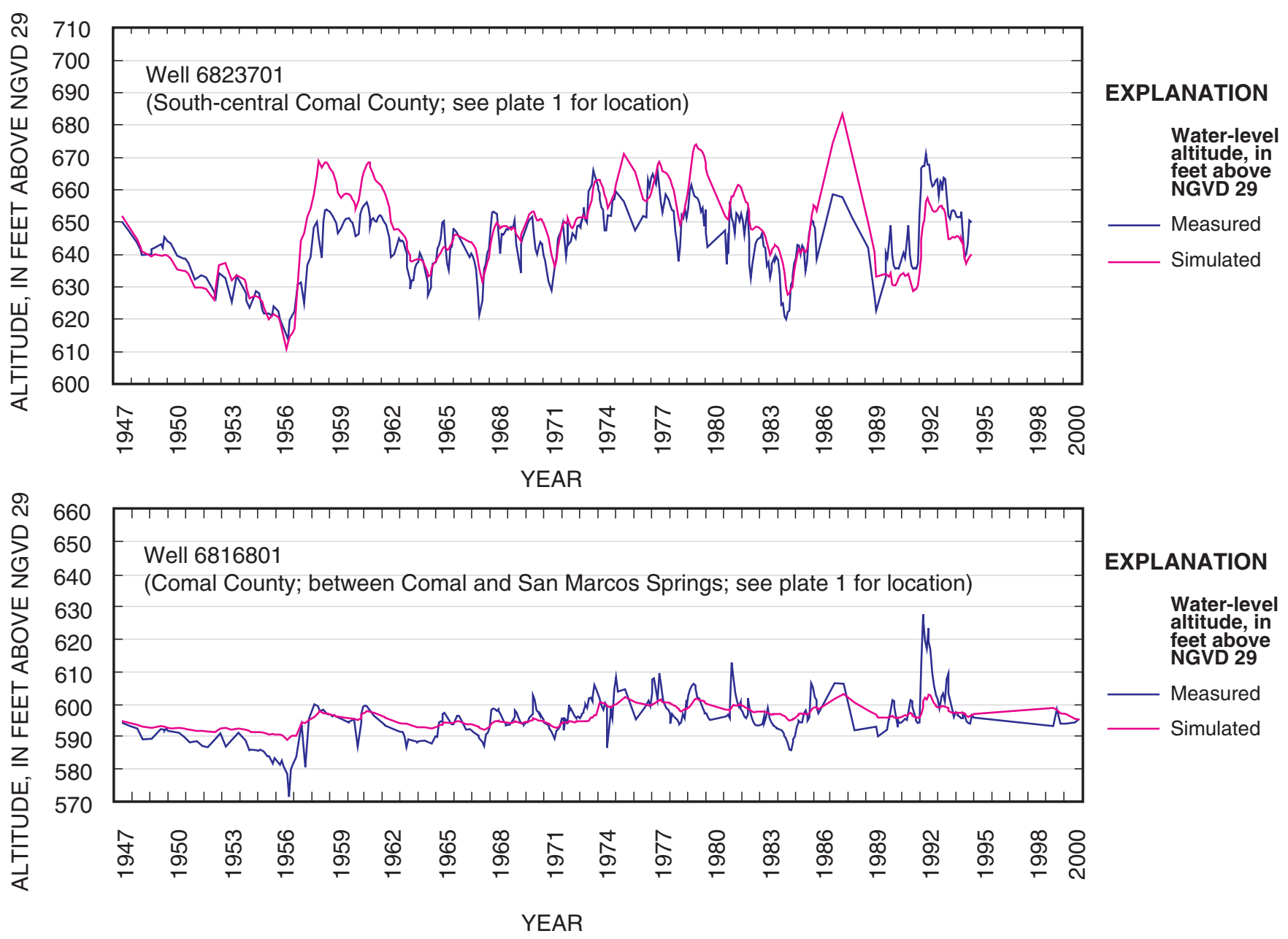

Figure 17a. Measured and simulated water levels (hydraulic heads) for Edwards aquifer wells in Comal County, San Antonio region, Texas.

requires that water moves into the confined zone from the recharge zone.

Hovorka and others (1996) approximated the change in volume of water in the aquifer that was caused by water-level change between a historical low level (1984) and the highest recorded water level (1992). The change in volume of water in the unconfined zone attributable to this change in water level was computed as 6.9 million acre-ft, which represents only 3 to 4 percent of the total water in storage throughout the aquifer. Removing more than this small percentage of the total volume would cause water levels to drop below historical (1984) low levels. Based on the difference between recharge and discharge (from wells and springs), there was a net gain of 2.93 million acre-ft of water in the aquifer between 1984 and 1992, which is about 42 percent of the change in volume of water in the unconfined zone attributable to the change in water level (Hovorka and others, 1996). This result indicates that the specific retention of the unconfined zone of the Edwards aquifer is 58 percent. Specific retention is the fraction of water in all water-filled pores of the unconfined aquifer that is not recoverable. Some water is not recoverable because it exists in discontinuous or poorly interconnected pore space or is held in the rock by surface tension or capillary attraction. Specific retention of 58 percent is consistent with the interpretation of Maclay and Small (1976) that at least 50 percent of pore space is undrainable by gravity.

\section{Simulation of Ground-Water Flow}

A conceptual model of the Edwards aquifer in the San Antonio region was formulated on the basis of the current (2004) understanding of the hydrogeologic setting, aquifer characteristics, distribution and amount of recharge and discharge, and aquifer boundaries, as described in the "Conceptualization of the Edwards Aquifer" section of the report. A numerical model of ground-water flow, the Edwards aquifer 
(b)
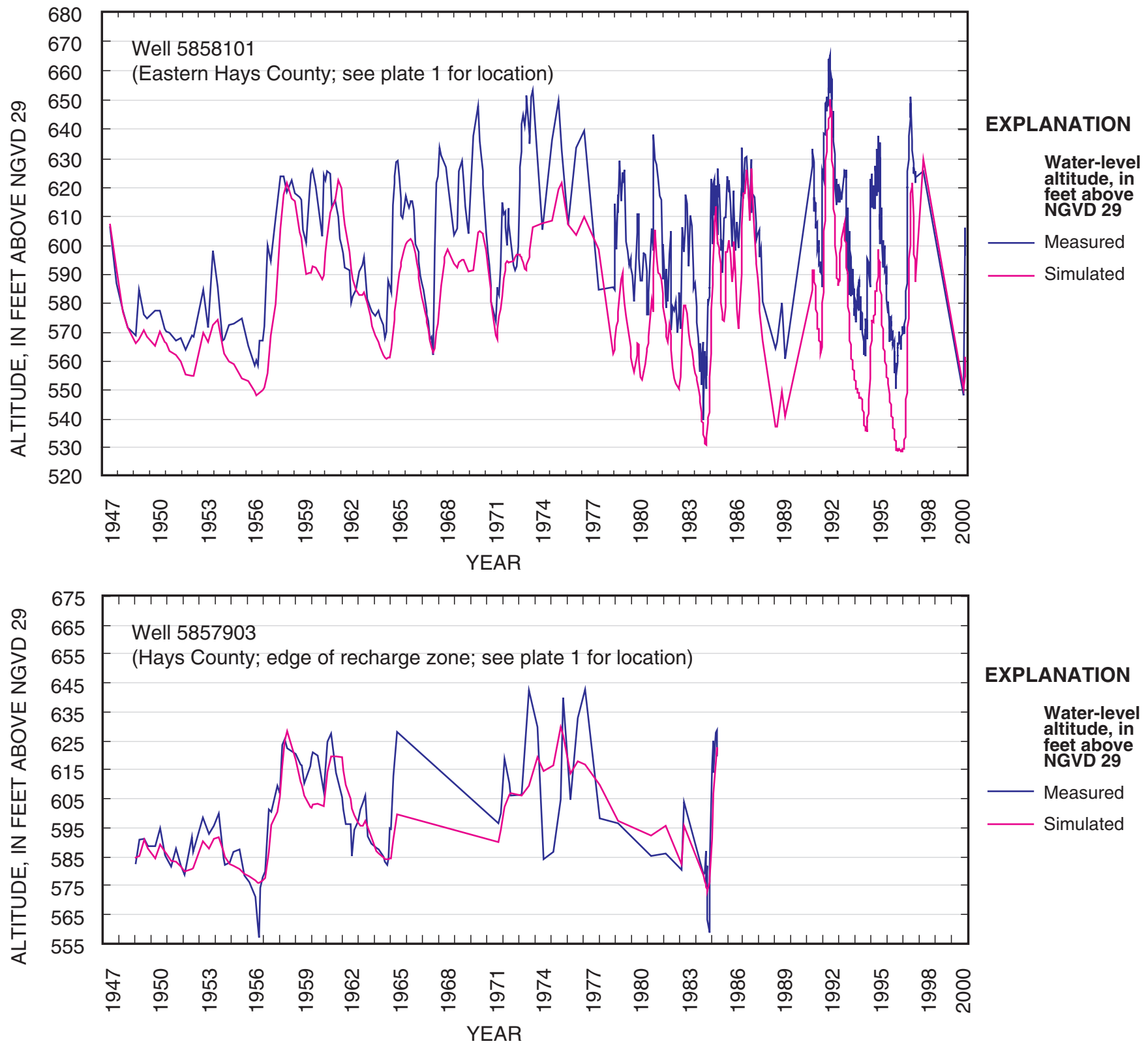

Figure 17b. Measured and simulated water levels (hydraulic heads) for Edwards aquifer wells in Hays County, San Antonio region, Texas.

model, was constructed on the basis of the conceptual model of the aquifer. Two types of simulations were done-a steadystate simulation that represents long-term average conditions when inflows to and outflows from the flow system are equal, and a transient simulation that includes changes in groundwater storage over time. In addition to providing scientists with an improved database and better understanding of the groundwater-flow system, this model will enable water managers to test the effects of alternative, potentially costly management scenarios before they are enacted. The input simplifications, graphics-rich output, and other enhancements make the model user-friendly for properly trained personnel.

\section{Numerical Model Description}

The Edwards aquifer model, in combination with its GISsupported database, resulted from an integration of the most complete hydrogeologic data assembled to date for the Edwards aquifer. The physical setting and dimensions of the Edwards 
aquifer were considered in determining the extent of the model area. Although the Edwards aquifer model includes generally the same geographic area as previous models of the Edwards aquifer in the San Antonio region (Klemt and others, 1979; Slade and others, 1985; Maclay and Land, 1988; Thorkildsen and McElhaney, 1992; Scanlon and others, 2002), it was expanded along the southern and southeastern boundaries. The southern (San Antonio segment) and southeastern (Barton Springs segment) boundaries of the Edwards aquifer model coincide with the mapped 10,000-mg/L dissolved solids concentration line, as recently revised by A.L. Schultz (consultant, written commun., 2000) (fig. 2). Previous models used the $1,000-\mathrm{mg} / \mathrm{L}$ dissolved solids concentration line to define the southern and southeastern boundaries. The model area also was expanded eastward to the Colorado River. Previous models have assumed a no-flow boundary at their eastern (San Antonio segment) or southwestern (Barton Springs segment) boundaries coincident with a ground-water divide in south-central Hays County near Kyle (fig. 1). The ground-water divide separates flow that moves southwestward toward San Marcos Springs from flow that moves northeastward toward Barton Springs. The location of this ground-water divide, however, is poorly defined and varies temporally (LBG-Guyton Associates, 1995).

The Edwards aquifer model area includes the San Antonio and Barton Springs segments of the Edwards aquifer (fig. 1). The San Antonio segment extends from near Bracketville in Kinney County to near Kyle in Hays County. The Barton Springs segment extends from near Kyle to the Colorado River in Travis County. The Barton Springs segment of the Edwards aquifer, terminating at the Colorado River, was included in the model to provide a comparatively definitive boundary condition. The alternative was to exclude the Barton Springs segment and use the poorly defined and temporally shifting groundwater divide near Kyle as the eastern model boundary. The use of the Colorado River as the eastern model boundary eliminates the need to impose a somewhat arbitrary boundary on the model and allows simulation results to indicate the position of the ground-water divide. Hydraulic heads and flows from wells and springs in the northern part of the Barton Springs segment of the aquifer (Travis County) were not used for model calibration. The purpose of including the Barton Springs segment in the Edwards aquifer model was to provide a more definitive, welldefined boundary condition, not to produce a calibration of the Barton Springs segment concurrent with Scanlon and others (2002). Hydrogeologic information for the Barton Springs segment from the Scanlon and others (2002) model was incorporated into the Edwards aquifer model. Initial values of hydraulic conductivity (from Scanlon and others, 2002) were modified in southern Hays County, however, during model calibration to better match measured hydraulic heads in that area and springflow for San Marcos Springs.

\section{Mathematical Representation}

The FORTRAN computer-model code MODFLOW (McDonald and Harbaugh, 1988; Harbaugh and McDonald, 1996; Harbaugh and others, 2000), a modular finite-difference ground-water-flow code developed by the USGS, was used to simulate ground-water flow in the Edwards aquifer. The Edwards aquifer model uses the Basic, Output Control, BlockCentered-Flow, Recharge, Well, Horizontal-Flow Barrier, Drain, River, and LMG (numerical solver) modules, or MODFLOW packages, to simulate ground-water flow in the Edwards aquifer. The software Groundwater Vistas was used as a pre- and post-processor to facilitate data entry and allow analysis of model output (Environmental Simulations, Inc., 2002).

MODFLOW uses a form of digital (numerical) processing known as finite-difference approximation to solve partial differential equations of ground-water flow (McDonald and Harbaugh, 1988). The flow equation, with specification of flow or head conditions, or both, at the boundaries of an aquifer system and specification of initial head conditions, constitutes a mathematical representation of a ground-water-flow system. MODFLOW simulates the response of the aquifer system (hydraulic heads and fluxes [flow per unit area]) to specified hydrologic stresses (sources [recharge] and sinks [discharge]). The primary sources of water simulated in the Edwards aquifer model are infiltration from rainfall and seepage from streams to the aquifer in the recharge zone and inflow of water from the Trinity aquifer along the northern model boundary. The primary simulated discharges of water are withdrawals by wells and springflows. The results of the model simulations are hydraulic heads at each finite-difference grid cell node, fluxes at headdependent flux boundary cells (drain, general-head, and river cells) or specified-flux boundary cells (northern model boundary, transient simulation), and mass water balances of the aquifer system.

A number of simplifying assumptions about the Edwards aquifer and boundary condition specifications were required to make mathematical representation of the aquifer possible.

These include

1. The Edwards aquifer is represented by a single model layer, although it includes multiple stratigraphic units with varying hydraulic properties within a vertical section. The single model layer has averaged, or composite, hydraulic properties.

2. The base of the Edwards aquifer in the confined zone is represented as a no-flow boundary. It is underlain by the Trinity aquifer. The upper zone of the Trinity aquifer is assumed to have a comparatively small hydraulic conductivity and to restrict vertical leakage to and from the Edwards aquifer.

3. In the recharge zone, the Edwards aquifer is unsaturated or thinly saturated in places. Hydraulic connection between the Edwards aquifer and the underlying, saturated Trinity aquifer and small vertical hydraulichead gradients were assumed. 
4. Anisotropy in the Edwards aquifer is represented by the effects of faults and the presence of conduits. Assigned hydraulic-conductivity values in the $\mathrm{x}_{-}, \mathrm{y}-$, and $\mathrm{z}-$ coordinate directions are the same.

5. Conduits can be represented in the model by narrow (onecell-wide) zones with large hydraulic-conductivity values. Although turbulent flow in the conduits is possible, laminar flow is assumed. The model calculates hydraulic heads and fluxes that approximate actual hydraulic heads and fluxes.

6. Flow between the freshwater/saline-water transition zone and saline-water zone of the Edwards aquifer is minimal.

7. A poorly defined ground-water divide near Bracketville in Kinney County constitutes a no-flow boundary.

8. Eighty-five percent of the recharge to the Edwards aquifer is assumed to occur as streambed leakage and the remaining 15 percent as direct infiltration in the interstream areas.

A description of the model includes the model grid and boundary conditions imposed, the structure and hydraulic properties of the aquifer, and the stresses on the aquifer. Pertinent hydraulic and hydrologic characteristics of the aquifer for appropriate cells within the grid are needed to solve the governing partial-differential equation. Specific parameters required for the model include (1) active and inactive cells, (2) altitudes of the top and bottom of the layer, (3) fault locations and horizontal conductance, (4) horizontal hydraulic conductivity, (5) storativity, (6) river stage and riverbed (streambed) conductance, (7) hydraulic head and conductance of general-head boundary, (8) recharge rates, (9) ground-water withdrawal rates, (10) drain altitude and conductance, and (11) initial hydraulic heads.

\section{Model Grid}

The study area was subdivided into rectangular finitedifference grid cells within which the properties of the aquifer are assumed to be uniform. The center of a grid cell is referred to as a node and represents the location for which the hydraulic head is computed by the model. The uniformly spaced finitedifference grid used to spatially discretize the model area has 370 rows and 700 columns (fig. 18). The dimensions of the grid cells are uniformly $0.25 \mathrm{mi}(1,320 \mathrm{ft})$ along rows and columns. Notation of the form $(11,24)$ is used to refer to the location of an individual cell within the grid, where the first number in parentheses indicates the row and the second number indicates the column. The origin of the grid is the northwest corner. A single model layer was used to represent the multiple hydrogeologic zones that comprise the Edwards aquifer. The Edwards aquifer was not discretized vertically because of a lack of sufficient hydrogeologic data needed to spatially define individual zones within the aquifer.

The grid was oriented to align the model as nearly as possible with the regional direction of ground-water flow and the major faults in the Balcones fault zone, with preference given to the direction of ground-water flow and orientation of major faults near Comal and San Marcos Springs. Accordingly, the grid was rotated 35 degrees counterclockwise from horizontal. The model grid includes areas beyond the boundaries of the confined zone of the Edwards aquifer on the south and the recharge zone on the north. Model cells in these areas were made inactive (no-flow cells), which resulted in about 33 percent of the cells in the grid active.

\section{Model Boundaries}

Ideally, all model boundaries should be located at the physical limits of the ground-water-flow system or at other hydrologic boundaries, such as a major river. Practical considerations, such as keeping the size of the model area reasonable might necessitate the use of arbitrarily imposed model boundaries in places where the natural hydrologic boundaries lie outside the model area.

Several major model boundaries used in previous Edwards aquifer models consisted of no-flow boundaries that prevented subsurface inflow and outflow from adjacent hydrogeologic units. These conditions (no-flow) necessitate the assumption that the Edwards aquifer is a closed system relative to other hydrogeologic units. No-flow boundary conditions used in previous Edwards aquifer models relate to (1) the position of ground-water divides near Kyle and Bracketville, (2) the flux from the Trinity aquifer to the Edwards aquifer at the northern limit of the recharge zone, (3) the prevailing estimated position of the downdip limit of flow, and (4) internal boundary conditions associated with major faults that act as barriers or conduits to regional flow.

Where possible, natural hydrologic boundaries were used to establish the extent of the active area of the Edwards aquifer model. These include the boundary of the Edwards aquifer recharge zone on the north, the boundary of the confined zone on the south, the Colorado River on the east, and a ground-water divide on the west. The northern boundary of the Edwards aquifer model corresponds to the physical limits of the Edwards aquifer and the eastern boundary with the location of a major river (fig. 18). The southern and western model boundaries are less well-defined hydrogeologic boundaries. The base of the Edwards aquifer was assigned a no-flow boundary condition.

\section{Northern Model Boundary}

The northern boundary of the Edwards aquifer model corresponds with the physical limits of the Edwards aquifer, more specifically with the northern limit of the Edwards aquifer recharge zone (fig. 18). A head-dependent flux boundary, rather than a no-flow boundary, was used for the northern model boundary to account for inflow from the adjacent Trinity aquifer. This head-dependent flux boundary condition was used during the steady-state simulation to estimate the equilibrium rate of inflow from the Trinity aquifer to the Edwards aquifer along the northern boundary. The head-dependent flux 
Inactive model area

-. -. Stream basin or contributing zone boundary

Boundary of recharge zone (outcrop) (modified from Puente, 1978) Boundary conditions

1) Head-dependent flux (general-head) boundary (steady-state simulation) Specified-flux boundary (transient simulation)

(2) Specified-flux boundary

(3) Head-dependent flux boundary (river)

(4) No-flow boundary

(5) No-flow boundary (coincides with per liter dissolved per liter dissolved
solids concentration line)

$\rightarrow \quad$ Spring

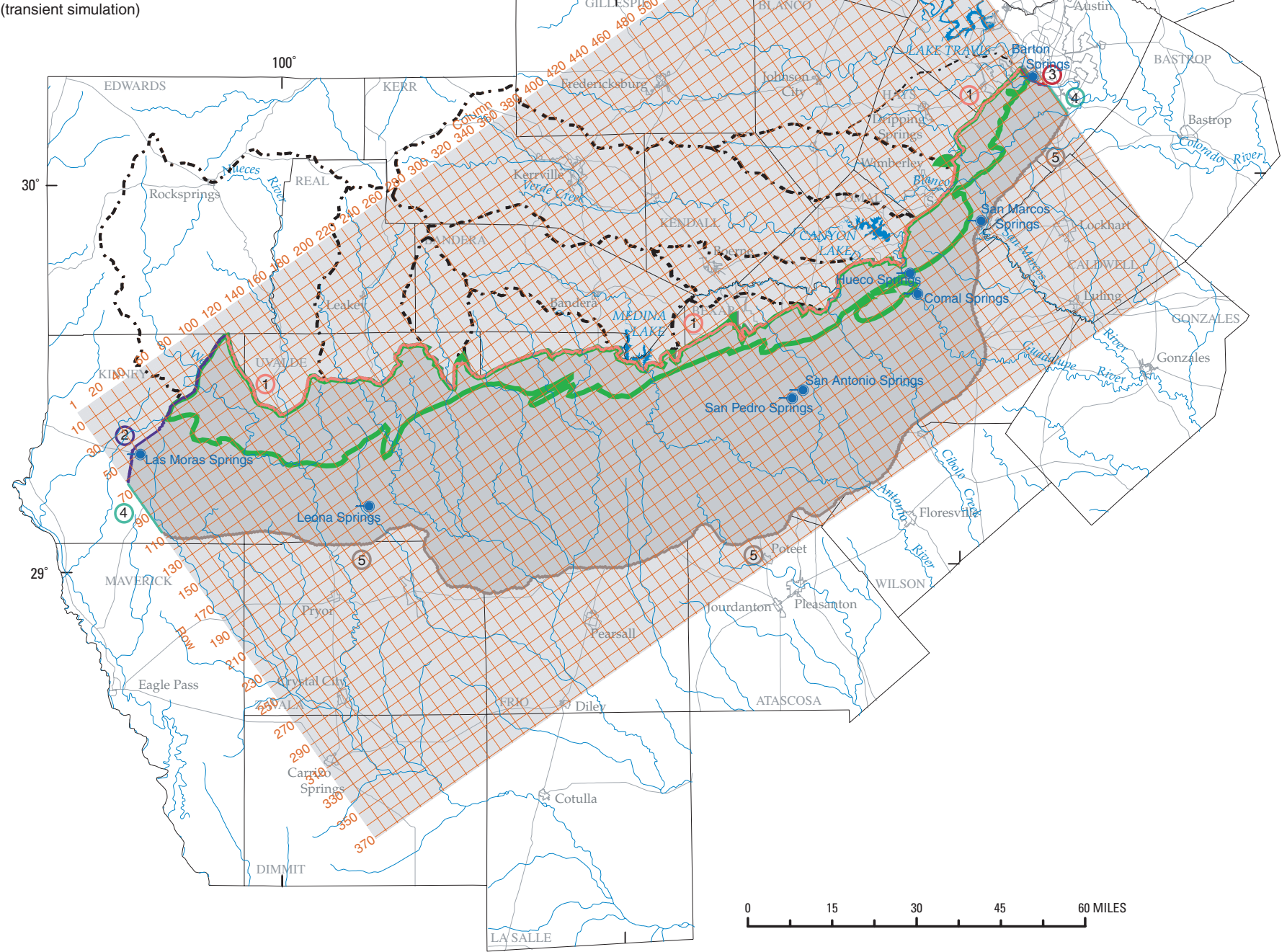


boundary condition was simulated using the MODFLOW general-head boundary package. In the general-head boundary package, flow into or out of a cell from an external source is proportional to (1) the difference between the head in the cell and the head assigned to the external source and (2) a conductance term (McDonald and Harbaugh, 1988).

Required general-head boundary parameters specified in the model include the (1) cell location, (2) head assigned to the external boundary, and (3) hydraulic conductance of the interface between the cell and the external boundary. The external source of water simulated is the Trinity aquifer, with the external boundary head corresponding to the hydraulic head in the Trinity aquifer north of the model boundary. The external boundary heads assigned in the steady-state simulation were based on a published historical (1915-69) potentiometric surface of the Edwards-Trinity aquifer system (Barker and Ardis, 1996, fig. 16). Conceptually, the hydraulic conductance represents the resistance to flow between a cell in the model and a constant-head source or sink and is derived from Darcy's Law (McDonald and Harbaugh, 1988). The hydraulic conductances assigned were based on (1) the geometry of the model cells, (2) an assumed 5-mi horizontal thickness for the boundary interface, (3) a saturated thickness of $150 \mathrm{ft}$ at the model boundary, and (4) a horizontal hydraulic conductivity of $1 \mathrm{ft} / \mathrm{d}$ for the boundary interface between the Edwards and Trinity aquifers.

During transient simulation, the MODFLOW well package was used to simulate a constant flux, equal to the modelcomputed general-head boundary flux of the steady-state simulation, through the northern model boundary for all stress periods. The assumption was made that water-level fluctuations in the Trinity aquifer near the boundary are similar to waterlevel fluctuations in the Edwards aquifer, resulting in a constant hydraulic gradient and rate of flow across the boundary.

\section{Eastern Model Boundary}

The northern part of the eastern model boundary is defined by the location of the Colorado River, which is a regional sink for the Edwards aquifer (fig. 18). Stream-aquifer leakage is simulated in the model as head-dependent flux nodes using the MODFLOW river package (McDonald and Harbaugh, 1988).

Streams contribute water to the ground-water system or drain water from it depending on the head gradient between the stream and the ground-water system. The purpose of the river package is to simulate flow between surface-water features and ground-water systems. Streams are divided into reaches, with each reach completely contained in a single cell. Stream-aquifer leakage through a reach of streambed depends on (1) the difference between stream stage and hydraulic head in the aquifer; or the difference between stream stage and the altitude of the streambed when the hydraulic head in the aquifer is below the streambed and (2) the conductance of the streambed, which is based on several parameters.

The assumption is made that measurable head differences between the stream and the aquifer are due to the presence of the streambed layer. In most cases, if water levels in the aquifer decline below the streambed, leakage from the stream to the aquifer remains at a constant rate. Further declines in head below the bottom of the streambed produce no increase in flow through the streambed layer. The conductance of the streambed is based on the vertical hydraulic conductivity, thickness, and area (length times width) of the streambed. The MODFLOW river package assumes that the stream-aquifer interaction is independent of the location of the stream reach within the cell and that stream stage is uniform over the reach, and constant over each stress period for transient simulations.

Required parameters in the river package include the (1) reach location (model cell), (2) hydraulic head in the river (river stage), (3) riverbed hydraulic conductance, and (4) altitude of the riverbed. The Colorado River was divided into 24 reaches ( 24 cells). The stage of the Colorado River for each reach was estimated from USGS 7.5-minute-quadrangle topographic maps. The Colorado River stage was not varied during transient simulations because measurements were not available. The riverbed hydraulic conductance for each reach was computed on the basis of the riverbed geometry and vertical hydraulic conductivity. River length and width were estimated from USGS 7.5-minute-quadrangle topographic maps. The vertical hydraulic conductivity and thickness of the riverbed are poorly defined and not easily measurable. Values of $1.0 \mathrm{ft} / \mathrm{d}$ and $1.0 \mathrm{ft}$ were assumed for the vertical hydraulic conductivity and thickness of the riverbed, respectively. The altitude of the riverbed for each reach was assigned a value equal to the river stage minus $10 \mathrm{ft}$.

The southern part of the eastern model boundary (south of the Colorado River) was assigned a no-flow boundary condition (fig. 18). Potentiometric-surface contours, constructed from available water-level measurements, indicate that ground-water flow near the southern part of the eastern model boundary is toward the Colorado River and approximately parallel to the model boundary.

\section{Western Model Boundary}

The western model boundary coincides with the location of a poorly defined ground-water divide near Bracketville in Kinney County (Garza, 1966; LBG-Guyton Associates, 1995). Minimal flow across this boundary was assumed and a no-flow boundary condition was initially assigned, as was done for previous numerical ground-water-flow models of the San Antonio segment of the Edwards aquifer (Klemt and others, 1979; Maclay and Land, 1988; Thorkildsen and McElhaney, 1992). During model calibration, however, a specified-flux boundary, with inflow into the Edwards aquifer, was imposed for the northern part of the boundary (fig. 18), on the basis of matching measured hydraulic heads near the boundary. LBG-Guyton Associates (1995) reported that water-level measurements indicate that a component of flow moves past Las Moras Springs from west to east toward the city of Uvalde. They further reported that the ground-water divide likely occurs to the west of Las Moras Springs. The southern part of the boundary was maintained as a no-flow boundary. 


\section{Southern Model Boundary}

Between its western and eastern limits, the Edwards aquifer in the San Antonio region is delimited to the south by a narrow transition zone between freshwater and saline water that minimizes the downdip flow of freshwater from the Edwards aquifer (fig. 2). The aquifer system boundary typically has been defined on maps by the 1,000-mg/L line of equal dissolved solids concentration, which coincides with the updip boundary of the transition zone (Schultz, 1993, 1994). Previous models of the Edwards aquifer in the San Antonio region (Klemt and others, 1979; Maclay and Land, 1988; Thorkildsen and McElhaney, 1992) have used the 1,000-mg/L dissolved solids concentration line as the southern boundary. The 10,000-mg/L concentration line was used in the Edwards aquifer model as a more conservative boundary, constituting the limit of groundwater flow in the confined zone of the aquifer. A no-flow boundary condition, therefore, was imposed for the southern model boundary coinciding with the $10,000-\mathrm{mg} / \mathrm{L}$ dissolved solids concentration line (A.L. Schultz, consultant, written commun., 2000) (fig. 18).

\section{Model Aquifer Structure}

Model aquifer structure considerations include assigning top and bottom altitudes of the Edwards aquifer to model cells and the simulation of faults and conduits. The top and bottom altitudes for the Edwards aquifer were determined using the procedures previously described in the "Structural Features" section of the report. The contoured structure surfaces, and faults (fig. 5), were digitized and gridded for input to the Edwards aquifer model. The initial locations specified for conduits in the Edwards aquifer model were those mapped by Worthington (2004) (fig. 7), discussed previously in the "Conduit Distribution and Characterization" section of the report.

\section{Aquifer Top and Bottom Altitudes}

The structure surfaces (aquifer top and aquifer bottom) were interpolated to the centers of model cells using GIS software. The altitudes of the aquifer top and aquifer bottom were specified for each active cell in the model grid. In the recharge zone, the altitude of the top of the aquifer coincides with the land-surface altitude. In the confined zone, overlying hydrogeologic units are present, and the top of the aquifer occurs at depth. The altitude of the top of the Edwards aquifer, where confined, coincides with the contact between the Georgetown Formation and Del Rio Clay. The altitude of the bottom of the Edwards aquifer coincides with the altitude of the top of the Glen Rose Limestone, except where modified in the recharge zone.

To adequately simulate the recharge zone and prevent unsaturated or thinly saturated parts from going dry (simulated water level falling below the simulated base of the model layer), the simulated bottom altitudes for the model layer were lowered sufficiently to maintain saturation in the model cells. In effect, a part of the underlying, lower-permeability Glen Rose Limestone of the Trinity aquifer was added to the model layer in these model cells. Initially, a minimum total thickness (initial Edwards aquifer thickness plus added thickness, if any) of $500 \mathrm{ft}$ was simulated for each cell in the recharge zone. During subsequent model calibration, the bottom altitudes for some cells were lowered further to prevent those cells from going dry. The bottom altitudes were lowered (thicknesses added) for about 90 percent of the model cells in the recharge zone (fig. 19). The thicknesses added ranged from zero to $800 \mathrm{ft}$. The thickness of the Edwards aquifer in some parts of the recharge zone is less than $10 \mathrm{ft}$, on the basis of the top and bottom altitudes derived as described previously in the "Structural Features" section of the report. Therefore, in these areas the added thickness constitutes nearly all of the total simulated thickness (all but $10 \mathrm{ft}$ or less). This is the case for about 9 percent of the cells in the recharge zone. The added thickness constitutes less than one-half of the total simulated thickness for about 33 percent of the model cells for which the simulated bottom altitudes were lowered. Hydraulic connection between the Edwards aquifer and the underlying saturated Trinity aquifer and small vertical hydraulic-head gradients were assumed, thereby justifying a composite model layer (Edwards and Trinity aquifers) in these areas of small or no Edwards aquifer saturated thickness. The same solution for the problem of cells going dry in the recharge zone was used by Scanlon and others (2002) in their model of the Barton Springs segment of the Edwards aquifer. Including a part of the Trinity aquifer in the Edwards aquifer model layer allowed those parts of the recharge zone where the Edwards aquifer is unsaturated or thinly saturated to be simulated without having to add complexity, such as a cell rewetting capability, to the model.

\section{Simulation of Faults}

The anisotropy of the Edwards aquifer is largely unknown, except for that attributable to the presence of faults. The anisotropic effects of faults were incorporated in the model using the MODFLOW horizontal-flow barrier package. The horizontal-flow barrier package simulates thin, vertical lowpermeability geologic features that impede the horizontal flow of ground water. These geologic features are approximated as a series of horizontal-flow barriers conceptually situated on the boundaries between pairs of adjacent cells in the finitedifference model grid. The width of the barrier is assumed to be negligibly small relative to the horizontal dimensions of the cells in the grid, and the barrier is assumed to have zero storage capacity. Its sole function is to lower the horizontal conductance between the two cells that it separates.

The horizontal-flow barrier package was used to simulate faults in the Edwards aquifer model (fig. 5). Required parameters include the (1) location of the fault and (2) hydraulic characteristic of the fault. The placement of horizontal-flow barriers in the model grid was determined by overlaying the model grid on an areal map of faults. Horizontal-flow barriers were placed at the boundaries of cells crossed by the trace of a fault. The 


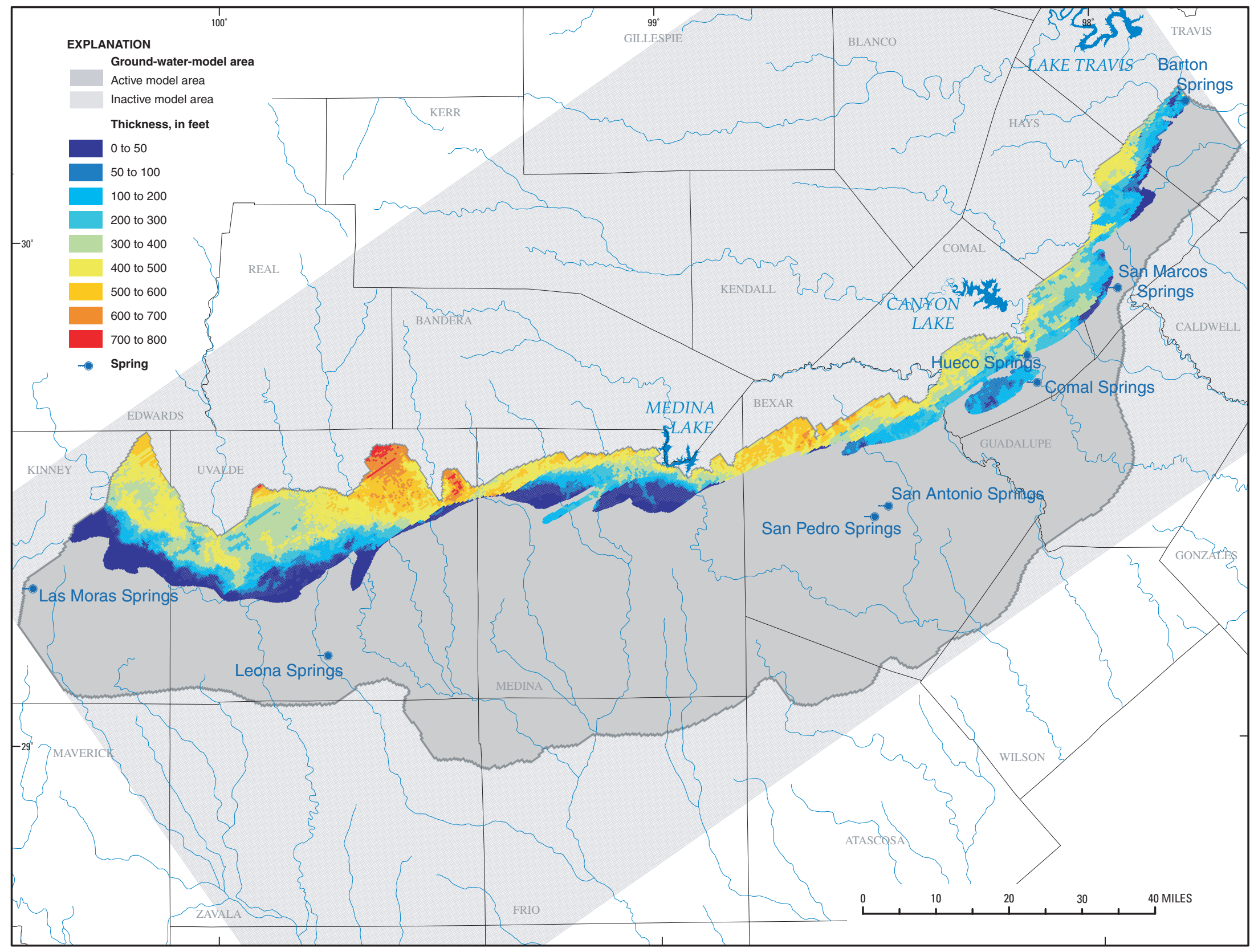

Figure 19. Thickness of underlying Trinity aquifer simulated in the Edwards aquifer recharge zone, Edwards aquifer model, San Antonio region, Texas. 
location of a horizontal-flow barrier (fault) is specified by the cell locations for the two cells that the barrier separates and acts as a barrier between.

The hydraulic characteristic of the barrier (fault) is an inverse measure of the degree to which it acts as a barrier to flow, defined as the barrier hydraulic conductivity divided by its width. The greater the assigned value for the hydraulic characteristic of the barrier, the less it acts as a barrier to flow. For the Edwards aquifer model, the assumption was made that the degree to which a fault acts as a barrier to ground-water flow is proportional to the fault displacement, with the hydraulic characteristic of the barrier being inversely proportional to the fault displacement. Because of the uncertainty of the components (barrier hydraulic conductivity and barrier width) typically used to compute the hydraulic characteristic, values for the hydraulic characteristic of faults were determined during model calibration. The horizontal-flow barriers were divided into categories on the basis of their associated fault displacements and a hydraulic characteristic assigned, with categories of greater fault displacements being assigned lower hydrauliccharacteristic values. The hydraulic-characteristic values for categories with large fault displacements were decreased during model calibration until the appropriate simulated barrier effect was achieved, on the basis of measured hydraulic heads and known effects of faults on ground-water-flow directions. The final, calibrated fault displacements (ranges) and hydrauliccharacteristic values are shown in table 2. Horizontal-flow barrier (fault) locations and fault displacements were compiled on the basis of then-current (2001) hydrogeologic and stratigraphic information.

Table 2. Fault displacement and simulated hydraulic characteristic for faults, Edwards aquifer model, San Antonio region, Texas.

\begin{tabular}{cc}
\hline $\begin{array}{c}\text { Fault displacement } \\
\text { (percent) }\end{array}$ & $\begin{array}{c}\text { Hydraulic characteristic }^{1} \\
\text { (days }^{-1} \text { ) }\end{array}$ \\
\hline $90-100$ & $1.0 \times 10^{-9}$ \\
$75-89$ & $1.0 \times 10^{-8}$ \\
$50-74$ & $1.0 \times 10^{-5}$ \\
$0-49$ & .02 \\
\hline
\end{tabular}

${ }^{1}$ Barrier (fault) hydraulic conductivity divided by fault width.

\section{Simulation of Conduits}

Karst aquifers can be conceptualized as including a discrete conduit network with frequently turbulent flow conditions, with conduits representing the major flow paths in the aquifer. As conduit flow might be frequently turbulent and restricted to discrete pathways, MODFLOW is not suited for the simulation of conduit flow. Use of a distributed, porousmedia model such as MODFLOW to simulate flow in a karst system is a simplification of the flow system. As a way to represent conduits, other than by use of a coupled-continuum pipe flow or dual-porosity or triple-porosity model, conduits are simulated in the Edwards aquifer model by narrow (one-cell, 0.25 -mi wide), initially continuously connected zones with large hydraulic-conductivity values. Previous numerical, distributed, porous-media, ground-water-flow models of the Edwards aquifer (Klemt and others, 1979; Maclay and Land, 1988; Thorkildsen and McElhaney, 1992; Scanlon and others, 2002) and other karstic carbonate aquifers (for example, the Floridan aquifer system in Florida and in parts of Georgia, South Carolina, and Alabama) have been able to reasonably simulate measured fluctuations in water levels in wells and springflow.

The locations of conduit zones in the Edwards aquifer model were assigned on the basis of the conduit locations inferred by Worthington (2004) (fig. 7). Conduit locations are based on a number of factors, including the presence of troughs in the potentiometric surface, geologic structure, and waterchemistry variations, previously discussed in detail in the "Conduit Distribution and Characterization" section of the report. The initial distribution of conduits formed a continuously connected system of large hydraulic-conductivity cells that links ground-water flow from the recharge zone and the western parts of the model area to Comal and San Marcos Springs in the eastern part of the San Antonio segment of the Edwards aquifer. Conduits also link the Blanco River Basin and the area east of San Marcos Springs in the San Antonio segment of the aquifer to San Marcos Springs. Conduits were not simulated in the Barton Springs segment of the aquifer as one-cell-wide, continuously connected zones, as for the San Antonio segment. Rather, the hydraulic-conductivity distribution of Scanlon and others (2002) was used. Although conduits were not used by Scanlon and others (2002), their hydraulic-conductivity distribution did include large hydraulicconductivity zones (maximum 1,236 ft/d) in the confined zone of the aquifer trending toward Barton Springs.

Faults were not simulated in model cells representing conduits, which results in breaks in mapped and simulated faults and facilitates unimpeded ground-water flow along the conduits. During model calibration, revisions were made to conduit locations to more closely match measured hydraulic heads and springflows. Some conduit segments were deleted, and some segments were added (fig. 7). One added segment links Leona Springs to the simulated conduit network.

\section{Model Hydraulic Properties}

The aquifer hydraulic properties specified in the model are horizontal hydraulic conductivity and storativity. Hydraulic properties were assigned to each active cell and were assumed to represent average conditions within the cell. Horizontal hydraulic conductivity, rather than transmissivity, was assigned to each active cell. Transmissivities are computed by the model at each iteration as the product of horizontal hydraulic conductivity and saturated thickness. Saturated thickness is computed by the model on the basis of the aquifer top and bottom altitudes 
and the model-computed hydraulic head. The transmissivities associated with the model cells in the unconfined part of the Edwards aquifer (primarily the recharge zone) vary as the saturated thicknesses vary. The transmissivities assigned to the model cells representing the confined part of the aquifer are constant in time.

\section{Horizontal Hydraulic Conductivity}

A major issue that emerged from the GWMAP was the initial hydraulic-conductivity distribution to be used in the Edwards aquifer model as a starting point for model calibration and the use of conduits, simulated as narrow (one-cell-wide), very large hydraulic conductivity, continuously connected zones. The decision reached was that the initial hydraulicconductivity distribution would include two components: The first component is the hydraulic-conductivity distribution developed by Painter and others (2002), discussed in detail previously in the "Transmissivity and Hydraulic Conductivity" section of the report. An approach based on nonparametric geostatistics, stochastic simulation, and numerical flow simulation was used to upscale and interpolate hydraulic-conductivity estimates to the Edwards aquifer model grid. The second component, superimposed on the base distribution of Painter and others (2002), is the network of conduits, as mapped by Worthington (2004, fig. 21) (fig. 7). This initial hydraulicconductivity distribution (Painter and others [2002] distribution plus conduits) was implemented in the model construction during the steady-state calibration and served as the starting point for the transient calibration.

The initial hydraulic-conductivity values for the base distribution of Painter and others (2002) for the San Antonio segment of the Edwards aquifer assigned to the cells of the model grid ranged from less than or equal to 20 to $7,347 \mathrm{ft} / \mathrm{d}$. For the Barton Springs segment of the aquifer, the hydraulicconductivity distribution from Scanlon and others (2002), rather than that of Painter and others (2002), was used. The hydraulic-conductivity values assigned to model cells in the recharge zone where the layer bottom altitudes were lowered (Edwards aquifer saturated thickness zero or small; see "Aquifer Top and Bottom Altitudes" section of the report) were reduced proportionately to the percentage of Trinity aquifer thickness added. Mace and others (2000) reported a geometric mean hydraulic conductivity of $0.54 \mathrm{ft} / \mathrm{d}$ for the upper zone of the Trinity aquifer and $2.6 \mathrm{ft} / \mathrm{d}$ for the middle zone of the Trinity aquifer. These values are appreciably lower than typical hydraulic conductivities for the Edwards aquifer. Horizontal hydraulic-conductivity values were subsequently varied during model calibration in the recharge zone, in Kinney County, and south of the 1,000-mg/L dissolved solids concentration line.

Liedl and others (2003) and Worthington (2004) indicate that conduits increase in size or number, or both, in the direction of downgradient springs. Therefore, initial values of hydraulic conductivity assigned to the conduits were (1) $1,000 \mathrm{ft} / \mathrm{d}$ for the conduit segments originating in the recharge zone, farthest from Comal and San Marcos Springs and areas of lesser conduit development (Hovorka and others, 1998; Worthington, 2004), (2) $100,000 \mathrm{ft} / \mathrm{d}$ for the segments in the confined zone of the aquifer, and (3) 200,000 ft/d for the segments in the confined zone of the aquifer in Comal and Hays Counties near Comal and San Marcos Springs. The large values of 100,000 and $200,000 \mathrm{ft} / \mathrm{d}$ are consistent with estimates on the order of $10^{5} \mathrm{ft} / \mathrm{d}$ reported by Hovorka and others (1998). Horizontal hydraulic-conductivity values for the conduit segments were subsequently varied during model calibration.

\section{Storativity}

Storativity values, including specific storage and specific yield, were assigned to each active cell for the transient simulations. No storage terms are included in the steady-state simulations because equilibrium conditions are assumed, with no change in storage in the aquifer. Transient simulations incorporate the storage property of the aquifer and are time dependent. Changes in storage in the aquifer occur when the amount of water entering the aquifer and the amount of water leaving the aquifer are not equal. Specific storage values apply under confined conditions and specific yield values apply under unconfined conditions.

Initially, uniform values for specific storage and specific yield were assigned to the active cells, on the basis of reported values from previous numerical ground-water-flow models of the Edwards aquifer (Maclay and Land, 1988; Scanlon and others, 2002). The initial values for the San Antonio segment of the aquifer were 0.05 and $2.0 \times 10^{-7} \mathrm{ft}^{-1}$ for specific yield and specific storage, respectively. The initial values for the Barton Springs segment of the aquifer were 0.005 and $5.0 \times 10^{-5} \mathrm{ft}^{-1}$ for specific yield and specific storage, respectively. Storativity values assigned to the model cells containing conduits were the same as those assigned to the non-conduit model cells, because no quantitative information regarding appropriate storativity values for conduits was available. Storativity values were subsequently varied during model calibration, resulting in a zonation of values.

\section{Recharge}

Stresses include recharge to and discharge from the Edwards aquifer. Recharge to the Edwards aquifer occurs primarily by seepage from streams to the aquifer in the recharge zone (fig. 2). Additional recharge is from infiltration of rainfall in the interstream areas of the recharge zone. Recharge to the aquifer by seepage from streams and infiltration of rainfall was assigned to eight major recharging streams and their interstream areas (recharge subzones) in the recharge zone (fig. 20), on the basis of monthly recharge rates to the Edwards aquifer for 1934-2000 computed by the USGS (table 3 at end of report) and published, as annual totals, by EAA. Average annual recharge rates for each of the eight recharge basins during 1939-46 were applied to the cells in the recharge zone for the steady-state simulation. Monthly recharge rates were applied for the 1947-2000 transient simulation. For the Guadalupe 


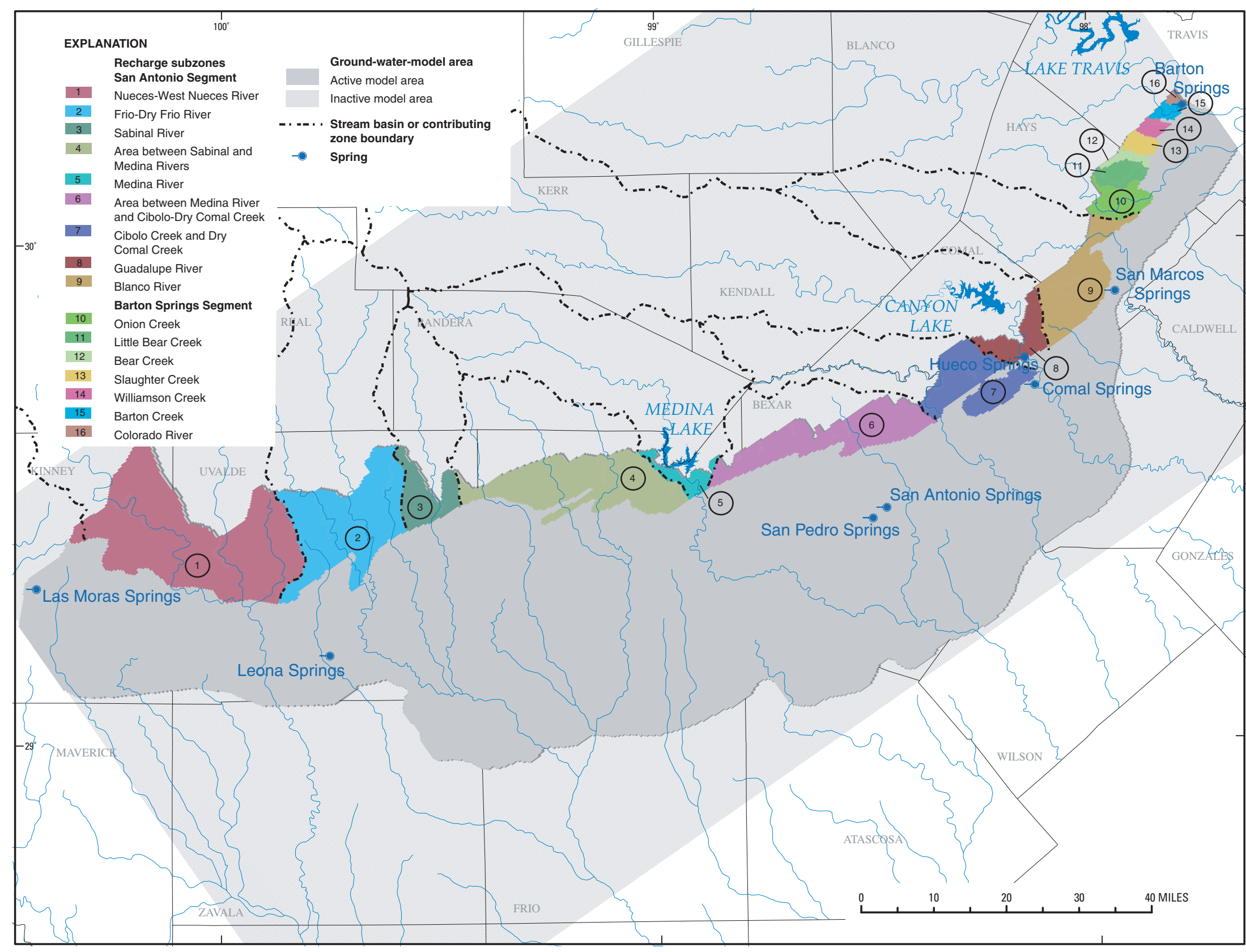


River recharge basin, only recharge attributable to infiltration of rainfall in the interstream areas was simulated. The rate assigned was equal to the average of the rates for the adjoining Cibolo Creek and Dry Comal Creek Basin and the Blanco River Basin. Annual and monthly recharge rates for six recharge basins in the Barton Springs segment of the aquifer (fig. 20) were derived from rates in Slade and others (1986) and rates compiled by B.R. Scanlon (University of Texas, Bureau of Economic Geology, written commun., 2001) for a numerical ground-water-flow model of the Barton Springs segment of the Edwards aquifer (Scanlon and others, 2002). Recharge rates attributable to infiltration of rainfall assigned to a seventh basin, the Colorado River Basin, were the same as those for the Barton Creek Basin.

For both the San Antonio and Barton Springs segments of the Edwards aquifer, 85 percent of the recharge was applied to streambed cells and the remaining 15 percent applied to the interstream cells. Available stream discharge measurements for the San Antonio segment of the aquifer indicate that streamflow generally is depleted to zero flow within the upper (upstream) part of the recharge zone for most recharge events, as a result of leakage to the aquifer. Therefore, for the San Antonio segment, recharge for each stream was applied only to the streambed cells in approximately the upper one-half of the recharge zone. For the Barton Springs segment of the aquifer, recharge was applied to streambed cells for the entire stream reaches in the recharge zone. This distribution of recharge for the Barton Springs segment is consistent with that used by Scanlon and others (2002). A specified-flux boundary, simulated using the MODFLOW recharge package, was used to represent recharge to the aquifer in the recharge zone (McDonald and Harbaugh, 1988). No recharge was applied to cells outside the recharge zone.

\section{Discharge}

Discharge from the Edwards aquifer includes withdrawals by wells and springflow. Withdrawal rates were assigned to model cells primarily on the basis of reported annual county totals and the locations of wells. Withdrawal rates for municipal, irrigation, industrial, mining, livestock, and power, in order of decreasing magnitude, were compiled by county for the period 1939-2000 (fig. 12). In the Edwards aquifer model, rural domestic withdrawals are included in municipal withdrawals, rather than spatially distributed throughout the model area. On average for the period 1939-2000, rural domestic withdrawals account for about 8 percent of total municipal withdrawals and about 5 percent of the total withdrawals assigned in the model. Also, the Edwards aquifer model did not include withdrawals from the Edwards aquifer for mining, livestock, or power. These three uses together accounted for less than 3 percent of total ground-water use in Uvalde, Medina, Bexar, Hays, and Travis Counties, and 5 percent or less in Kinney County. In Comal County these three uses might constitute as much as 25 percent of total ground-water use, primarily attributable to mining. This mining water use, however, is by quarries and is probably largely non-consumptive use, with much of the pumped water re-entering the Edwards aquifer.

Comal, San Marcos, Leona, San Antonio, and San Pedro Springs were simulated in the Edwards aquifer model and used for model calibration (fig. 1). Barton and Las Moras Springs were simulated as sinks near the model boundaries, but were not used for model calibration. Barton Springs was not used for model calibration because the Barton Springs segment was not calibrated, as discussed previously. Las Moras Springs was not used for calibration because much of its springflow might be derived from west of the nearby simulated model boundary (figs. 1, 18). Hueco Springs, in Comal County north of Comal Springs (fig. 1), was not simulated because of the complexity of the flow relations between the Edwards and Trinity aquifers in the area of the springs. Much of the Hueco Springs discharge might be derived from the Trinity aquifer.

\section{Withdrawals by Wells}

Withdrawals by wells were compiled and distributed temporally and spatially within the model grid. The MODFLOW well package was used to simulate the withdrawals by wells. As with recharge, average withdrawal rates during 1939-46 were used for steady-state simulations, and monthly rates were assigned for each stress period of the transient simulation. The distribution of simulated withdrawals in the Edwards aquifer model for the steady-state simulation and during 2000 is shown in figure 21 .

The assignment of withdrawals rates for the Edwards aquifer model used primarily four sets of information:

1. Total annual county withdrawals for 1939 to 2000 ;

2. Proportion of total withdrawals by water-use group;

3. Location of wells and distribution of withdrawals within each county; and

4. Discretization of annual withdrawals rates into monthly rates.

Hamilton and others (2003, table 6.1) report estimates of total ground-water discharge by county (Kinney/Uvalde, Medina, Bexar, Comal, and Hays) and total six-county well and total six-county spring discharge for 1934-2002. The total ground-water discharge of Hamilton and others (2003, table 6.1) (sum of the six-county totals) for 1939-2000 is shown in figure $12 \mathrm{a}$. To assign withdrawal rates to counties, the sixcounty total well discharge of Hamilton and others (2003) had to be subdivided by county. To do this, USGS computed springflows for Comal, Las Moras, Leona, San Antonio, San Marcos, and San Pedro Springs by interpolating between individual flow measurements, following the methods used by Hamilton and others (2003), and summed the springflows by county (C.L. Otero, U.S. Geological Survey, written commun., 2001). There is an average 3- to 4-percent difference between the sum of the newly computed county springflows and the total springflow of Hamilton and others (2003, table 6.1). County withdrawal rates (fig. 12c, table 4 at end of report) for Kinney/Uvalde, Medina, 


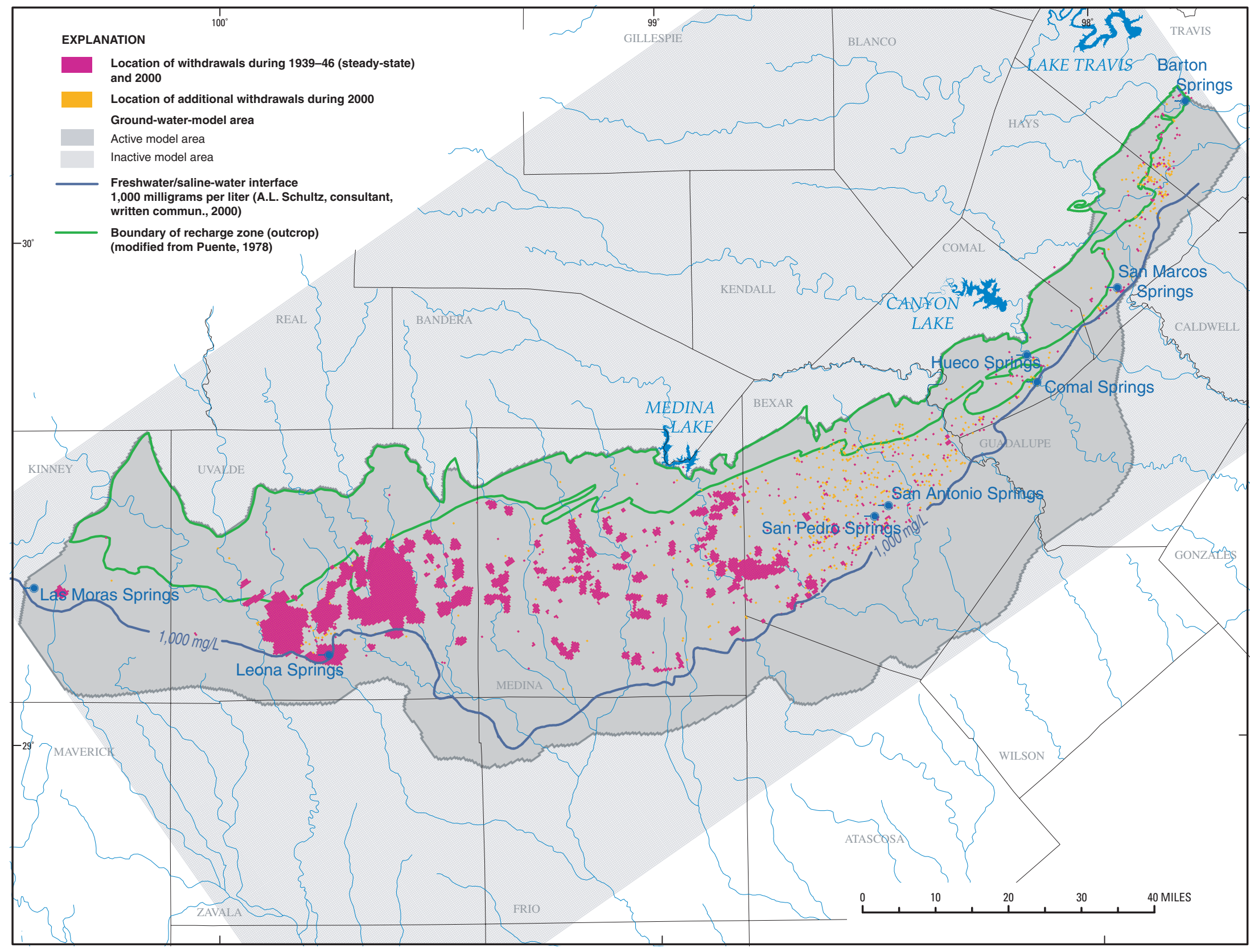

告

Figure 21. Distribution of withdrawals during 1939-46 (steady-state simulation) and 2000, and additional withdrawals for 2000, Edwards aquifer model, San Antonio region, Texas. 
Bexar, Comal, and Hays Counties thus were derived by subtracting the newly computed county springflows from the county total discharge estimates of Hamilton and others (2003, table 6.1). The combined Kinney/Uvalde County withdrawals of Hamilton and others (2003, table 6.1) were divided into respective county totals on the basis of proportions from individual county withdrawal data from the Texas Water Development Board (1997). Withdrawals for Travis County were estimated from a correlation between Travis and Bexar County withdrawal data for 1989-97 (data from Texas Water Development Board [1997]). For the 1980s and 1990s, withdrawals from the Edwards aquifer in Bexar County have averaged about 1.6 times the total amount in the other counties in the model area.

Total county withdrawals for 1939-2000 were subdivided by water-use category using TWDB estimates of withdrawals by water-use group for 1980-97 (Texas Water Development Board, 1997) (fig. 12b). Water-use categories included municipal, manufacturing (industrial), power, mining, irrigation, and livestock water. The average proportion of total use by wateruse category was estimated for each county for the 1980-97 period. This average proportion was applied to the entire simulation period of 1939-2000 to subdivide county total withdrawals into amounts for the various water uses.

Locations of almost 4,300 wells were compiled from several sources, including

1. Petitt and George (1956);

2. TWDB online ground-water database (Texas Water Development Board, 2003);

3. Records of public water-supply wells compiled by the Texas Commission on Environmental Quality; and

\section{USGS open-file records.}

Locations could be assigned for 1,060 public water-supply wells and 175 industrial/manufacturing wells, which were included in the Edwards aquifer model.

Total county withdrawals were assigned to wells by wateruse category on the basis of the number of wells in that category that existed for each year. Installation data for each well was noted; if no drilling date was reported then the well was assumed to have been drilled before 1939. The number of located public water-supply wells and industrial wells included in the model almost tripled from 1939 to 2000, from about 440 to 1,235 . A given model cell might represent more than one well. Model cells to which municipal and industrial use withdrawals were applied increased from about 530 for the 1939-46 steady-state period to about 1,220 in 2000.

Rural domestic ground-water use was separately estimated from TWDB data for 1980-97 (Texas Water Development Board, 1997). The average ratio of rural domestic withdrawals to municipal withdrawals for 1980 through 1984 was used to derive rural domestic withdrawals for 1939 through 1979. Rural domestic withdrawals were distributed on the basis of the proportion of total county population accounted for by rural population in each model-cell area. For 1990 through 2000, rural domestic withdrawals were distributed on the basis of 1990 and 2000 census results. Population in census tracts was linked to the grid of model cells, excluding municipal areas with more than 500 people. This rural population was linearly interpolated for model cells for each year between 1990 and 2000. Rural population for 1939 through 1989 was prorated on the basis of the ratio of county total population in the year of interest to the 1990 county total population.

Withdrawals for irrigation water use were distributed using GIS data from the TWDB 1994 irrigation-use survey (Texas Water Development Board, 1996). That GIS database identified polygons with irrigated acreage and specified the percentage of the polygon area under irrigation in 1994. The Edwards aquifer model assigned irrigation withdrawals to nearly 5,200 model cells. Withdrawals were proportionately distributed across the model grid to those cells with irrigated acreage. The cells designated with irrigation withdrawals remained constant for the 1939 through 2000 period, although the irrigation withdrawal rates assigned to those cells changed by stress period.

The areal distribution of annual water use by category for 1996 (municipal, industrial, and irrigation) is shown in figure 13a. Where model cells were assigned withdrawals for multiple uses, the priority for displaying the use category in figure 13a is municipal greater than industrial greater than irrigation. A cell was assigned municipal withdrawals, for example, either if municipal is the only use of ground water or if municipal and other uses apply to the cell.

The total for the TWDB municipal-use category includes both public water supply and rural domestic ground-water use. Rural domestic withdrawals were assigned to about 53,000 model cells on the basis of GIS data on population from the 1990 census and the 2000 census. The model calibration simulations, however, did not include a spatial allocation of well discharge for rural domestic withdrawals to keep the size of the withdrawal input files manageable. Rather than leaving well discharge for rural domestic withdrawals out of the model, however, the calibration simulations included rural domestic withdrawals within municipal withdrawals. That is, total municipal ground-water use was allocated to wells for calibration simulations without any reduction to reflect rural domestic water use. In effect, withdrawals were concentrated by including rural domestic withdrawals with municipal withdrawals at fewer enumerated wells, rather than distributing rural domestic withdrawals to a large number of widely distributed cells.

The effect of not spatially distributing rural domestic withdrawals in the model might be to locally overestimate withdrawals and drawdown in and around cells with public watersupply wells and to regionally underestimate a small amount of withdrawals and drawdown representing rural domestic population. The effect differs by county. Rural domestic withdrawals in Bexar County, for example, averaged less than 6 percent of municipal withdrawals, whereas they averaged 56 to 77 percent of municipal withdrawals in Medina County.

The total annual withdrawal rate for municipal, industrial, and irrigation uses included in the Edwards aquifer model is 


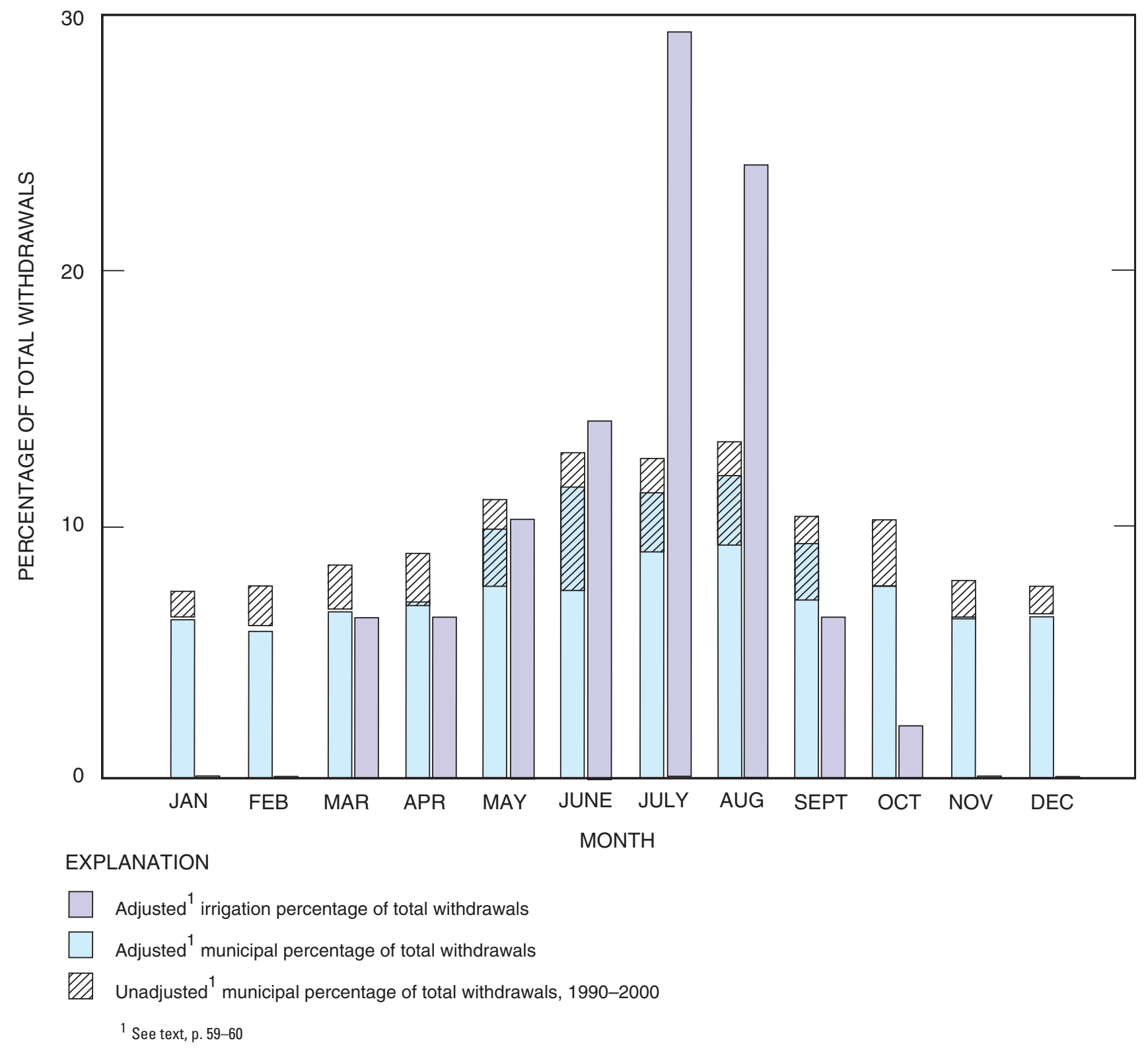

Figure 22. Variation in monthly percentages of total annual withdrawals for municipal and irrigation withdrawals simulated in the Edwards aquifer model, San Antonio region, Texas.

shown in figure 13a for 1996, a year with one of the highest total annual withdrawal rates for the decade. Some cells have all three types of water use. Withdrawals are displayed as colored "pixels" sized to the model grid-cell dimensions. In 1996, more than 460 public water-supply wells in various counties discharged between 50 and 100 acre-ft/yr per well, and more than 470 wells in Bexar County discharged between 500 and 550 acre-ft/yr per well.

The annual well discharge estimates were subdivided into monthly amounts for the monthly stress periods in the Edwards aquifer model. Municipal, rural domestic, and irrigation withdrawals were assumed to vary monthly. Municipal and rural domestic rates were varied using monthly withdrawal information for 1990-2000 for SAWS wells (San Antonio Water System, 2000) (fig. 22). Average monthly rates (for the 11-year period 1990-2000) as a percentage of total annual withdrawals initially were computed, and the ranges in percentages for each month are shown in figure 22 ("unadjusted municipal percentage of total withdrawals"). However, it was recognized that the average is less than the maximum rate. To simulate a greater, more realistic seasonal range in withdrawal rate, the maximum rates for May through September during 1990-2000 and the average rates for other months were used to compute revised, more realistic monthly percentages of total annual withdrawals. 
The resulting 12 monthly percentages of total annual withdrawals summed to 112 percent; therefore, they were uniformly adjusted downward to sum to 100 percent. Because of this downward adjustment, the percentages ("adjusted municipal percentage of total withdrawals," fig. 22) are less than the maximum percentages for May through September and less than the average percentages for other months (fig. 22). Total annual municipal and rural domestic withdrawals were multiplied by the respective monthly percentages to derive monthly withdrawals.

Withdrawals for industrial use were assumed to be constant during the year; annual industrial withdrawals, therefore, were evenly distributed by month throughout the year. Monthly rates for irrigation varied in proportion to the average (19542000) monthly deficits of rainfall minus lake evaporation. The monthly irrigation percentages of total irrigation withdrawals were derived from the monthly deficits of rainfall minus lake evaporation, with the months with the largest percentages corresponding with the months with the largest deficits. Irrigation was assumed to be zero from November through February. The initial monthly irrigation percentages of total annual irrigation withdrawals for March through October were adjusted to sum to 100 percent ("adjusted irrigation percentage of total withdrawals," fig. 22). Total annual irrigation withdrawals were multiplied by the respective monthly percentages to derive monthly withdrawals.

\section{Springflow}

Discharge from the Edwards aquifer includes springflow. Seven springs (Comal, San Marcos, Leona, San Antonio, San Pedro, Barton, and Las Moras) (fig. 1) were simulated in the model using the MODFLOW drain package. The MODFLOW drain package simulates the effects of features that remove water from the aquifer at a rate proportional to the difference between the hydraulic head in the aquifer and some fixed head or altitude (McDonald and Harbaugh, 1988). The head computed by the model for the cell in which the simulated drain (spring in this report) occurs is actually an average for the cell, representative of the head at the cell node (center of the cell).

This model-computed head for the cell normally is assumed to prevail at some distance from the drain itself, because the cell size is generally much greater than the drain size. The drain head, in contrast, prevails only locally, within the drain-it does not characterize the cell as a whole. Between the drain and the area in which the head in the cell prevails there exists a radial or semiradial flow pattern in the vertical plane, normally characterized by progressively steeper head gradients as distance to the drain decreases. Flow into the drain generates head losses owing to three processes - convergent flow toward the drain, flow through material of different conductivity immediately around the drain, and flow through the wall of the drain. These head losses are assumed to be proportional to the discharge through the drain. Discharge from the drain is defined as

$$
Q=C\left(H_{c}-H_{d}\right), H_{c}>H_{d}
$$

$$
Q=0, H_{c} \leq H_{d}
$$

where

$Q$ is the drain discharge $\left[\mathrm{L}^{3} / \mathrm{t}\right]$,

$C$ is a lumped hydraulic conductance describing all of the head loss between the drain and the region of the cell in which the head in the cell is assumed to prevail $\left[\mathrm{L}^{2} / \mathrm{t}\right]$,

$H_{c}$ is the head in the cell [L], and

$H_{d}$ is the head within the drain [L].

The conductance depends on the characteristics of the convergent flow pattern toward the drain, as well as on the characteristics of the drain itself and its immediate environment. Because information defining these factors is generally lacking, conductance typically is adjusted during model calibration to match measured values of discharge to simulated values.

Required parameters in the drain package include the (1) drain location, (2) altitude of the drain, and (3) lumped hydraulic conductance of the interface between the aquifer and the drain. The drain altitude commonly is specified as the landsurface altitude of the spring orifice or spring pool altitude as applicable. The initial simulated drain altitudes for Comal and San Marcos Springs were based on the altitudes of streamflowgaging stations used to estimate the springflows. These altitudes are lower than the altitudes of any of the multiple spring orifices for each spring, thereby more closely representing the drain altitude at which springflow would cease as hydraulic heads in the aquifer decline.

\section{Numerical Model Calibration}

Model calibration is the process in which initial estimates of aquifer properties, stresses (recharge), and boundary conditions are adjusted until simulated hydraulic heads and flows acceptably match measured water levels and flows. Regarding flows, for the Edwards aquifer model, aquifer properties, recharge, and boundary conditions were adjusted to produce an acceptable match between simulated and measured springflows for Comal, San Marcos, Leona, San Antonio, and San Pedro Springs. Calibration and evaluation of the ground-water-flow model were conducted for steady-state (1939-46) and for transient (1947-2000) conditions. Transient simulations incorporate the storage property of the aquifer and are time-dependent. Changes in storage in the aquifer occur when the amount of water entering the aquifer and the amount of water leaving the aquifer are not equal.

The calibrated input data incorporate refinements to unpublished, as well as published, data on hydraulic conductivity (and transmissivity), storativity, and recharge. The final distributions of hydraulic conductivity (transmissivity), storativity, and recharge result from the outcome of trial-and-error calibration. During calibration, the input data were adjusted (within measured ranges of variability) to minimize differences between simulated and measured hydraulic heads and springflow. The primary parameters varied during the steady-state 
calibration were recharge, horizontal hydraulic conductivity, and aquifer-to-spring (spring-orifice) conductance. The primary parameters varied during the transient calibration were recharge, storativity, and spring-orifice altitude.

Once it was demonstrated that the model could approximate observed historical conditions (1947-90), the model was then used to simulate the effects of stresses for a time period not used initially for model calibration (model testing period, 19912000). The purpose of model testing is to establish greater confidence in the model by using the set of calibrated parameter values and stresses to reproduce a second set of field data. The model testing period included periods of both appreciably below-normal and appreciably above-normal rainfall and recharge. The estimated recharge during 1996 was 324,293 acre-ft for the San Antonio segment of the Edwards aquiferless annual recharge occurred in only 15 of the years during 1934-2000. The estimated recharge during 1992 was 2,485,693 acre-ft for the San Antonio segment, the highest estimated recharge on record. The calibrated model could be used in the future to simulate the likely effects of changes in the simulated system, either natural or proposed. Thus, the effects of increases or decreases in the rates of recharge or discharge because of flooding, drought, or alternative withdrawal scenarios might be evaluated.

The calibration targets for the Edwards aquifer model include measured water levels in wells and springflows. The water-level targets include (1) the averages of a series of measurements of water levels in multiple wells for a specified time period (steady-state calibration targets), (2) single measurements of water levels in multiple wells within a comparatively short time period, producing an areal distribution of hydraulic heads (potentiometric-surface map) (transient calibration target), and (3) a series of measurements of water level within a single well over time (hydrograph) (transient calibration target). Similarly, the springflow targets include (1) the median value of a series of measurements of springflow for a single spring for a specified time period (steady-state calibration target) and (2) a series of measurements of springflow for a single spring over time (transient calibration target; hydrograph).

The sets of wells used in the steady-state and transient model calibrations are partially overlapping. In other words, some wells are used only for (have water-level measurements suitable for) the steady-state calibration, some wells are used only for the transient calibration, and some wells are used for both calibrations. To be used for the steady-state calibration, a well needed to have water-level measurements during 1939-46. For the transient calibration, a well needed to have water-level measurements (1) over an extended period of time (at least 10 years), or (2) during May 1956 through November 1956 (drought period), or (3) during November 1974 through July 1975 (above-normal rainfall period).

Springflow measurements for Comal, San Marcos, Leona, San Antonio, and San Pedro Springs were available for at least parts of the entire 1939-2000 period. The springflows for these five springs were used as calibration targets for both the steadystate and transient calibrations. Springflows for time periods lacking measurements were estimated by interpolation or relations to index wells.

\section{Steady-State Simulation}

The steady-state calibration period for the Edwards aquifer model was 1939-46. Although hydrologic conditions in the Edwards aquifer have fluctuated broadly, depending on the associated distributions of recharge and water use, long-term averages of recharge, discharge, and water-level data were assembled from a near-predevelopment (pre-1947) interval to provide an appropriate representation of hydraulic equilibrium, or steady state. The period 1939-46 was chosen because (1) irrigation development was minimal, (2) average rainfall for the period was near the 30-year normal (1961-90) rainfall (National Oceanic and Atmospheric Administration, 1992), and (3) sufficient water-level and springflow information was available.

\section{Calibration Targets}

Although average rainfall for the period 1939-46 was near the 30-year normal, an analysis of hydrographs indicated that appreciable fluctuations in water levels in wells occurred during this time period. Therefore, to minimize the effect of these fluctuations and obtain more representative average (equilibrium) water levels for 1939-46, only the time periods during 1939-46 with water levels within the range of the middle 50 percent of measured values (between the 25 th and 75 th percentiles) during 1939-46 in the Bexar County (J-17, TWDB 6837203) and Uvalde County (J-27, TWDB 6950302) index wells were used for computing average water levels in wells. About 1,500 wells in the TWDB well database (Texas Water Development Board, 2003) in the model area (excluding Travis County) were completed in the Edwards aquifer and had water-level information. Of these approximately 1,500 wells, 144 wells had water-level measurements during the time periods of average (middle 50 percent of measured values) 1939-46 water levels in the index wells. These 144 wells were used as the calibration targets for the steady-state calibration (table 5 at end of report).

In addition to water levels in wells, median springflows for Comal, San Marcos, Leona, San Antonio, and San Pedro Springs for 1939-46 were used as targets for the steady-state calibration. The median springflows are 330, 152, 15.5, 10.2, and $6.3 \mathrm{ft}^{3} / \mathrm{s}$ for Comal, San Marcos, Leona, San Antonio, and San Pedro Springs, respectively.

\section{Changes From Initial Values}

The steady-state simulation was calibrated by varying the simulated recharge rates, hydraulic conductivities, and springorifice (drain) conductances, and by revisions to some conduit segments. The changes from initial values needed to calibrate the steady-state simulation are summarized in table 6 (at end of report). Simulated recharge rates for the steady-state simulation were varied within the range of reported recharge during 1939- 
46 for the Nueces-West Nueces River recharge subzone and the Cibolo Creek and Dry Comal Creek subzone to more closely match measured hydraulic heads and springflows; simulated recharge rates for the Onion Creek subzone also were varied. The simulated recharge rate for the Cibolo Creek and Dry Comal Creek subzone was decreased by 25 percent compared to the reported mean 1939-46 rate (table 7 at end of report). Simulated recharge rates for the Nueces-West Nueces River and Onion Creek recharge subzones were increased by 50 percent (table 7).

The initial hydraulic-conductivity values in Kinney County and south of the $1,000-\mathrm{mg} / \mathrm{L}$ dissolved solids concentration line (fig. 2) were varied to more closely match measured hydraulic heads and springflows. The hydraulic-conductivity values in Kinney County were decreased to 1 to $5 \mathrm{ft} / \mathrm{d}$ in the confined zone and to $25 \mathrm{ft} / \mathrm{d}$ in parts of the recharge zone from the distribution of Painter and others (2002) (fig. 8). These comparatively small hydraulic conductivities were needed to maintain the simulated hydraulic heads at the levels of the measured hydraulic heads near the western model boundary. Also, as previously indicated in the "Western Model Boundary" section of the report, the northern part of the western model boundary was changed from a no-flow to a specified-flux boundary condition, with flow into the model area across the boundary, to more closely match measured hydraulic heads near the boundary. In addition, a barrier fault, simulated using the MODFLOW horizontal-flow barrier package, trending southwest-northeast was added in the recharge zone in Kinney County to divert groundwater flow to the southwest and reduce unobstructed flow to the southeast. The addition of the barrier fault helped to maintain higher hydraulic heads near the western model boundary and is aligned with a major lineament mapped by Maclay (1995, fig. 4). This barrier fault is located and oriented similarly to an anisotropy zone with a 1-to-10 ratio of transmissivity in the $\mathrm{y}$-direction to transmissivity in the $\mathrm{x}$-direction used by Maclay and Land (1988, fig. 20).

Hydraulic-conductivity values also were decreased south of the 1,000-mg/L dissolved solids concentration line (fig. 2) to $1 \mathrm{ft} / \mathrm{d}$ for much of the San Antonio segment of the aquifer (Frio County and eastward) from the distribution of Painter and others (2002) (fig. 8). These relatively small hydraulicconductivity values for the freshwater/saline-water transition zone are consistent with simulated values from previous Edwards aquifer numerical ground-water-flow models (Maclay and Land, 1988; Scanlon and others, 2002). In addition, hydraulic-conductivity values were decreased (from about 50 to $75 \mathrm{ft} / \mathrm{d}$ to about 20 to $50 \mathrm{ft} / \mathrm{d}$ ) for parts of the recharge zone to prevent model cells from going dry during the steady-state simulation. Revisions also were made to the hydraulic-conductivity values assigned to the conduit segments. The maximum hydraulicconductivity values for some of the conduit segments originating in the recharge zone were increased to $2,000 \mathrm{ft} / \mathrm{d}$ and to $300,000 \mathrm{ft} / \mathrm{d}$ for some of the segments in the confined zone of the aquifer in Bexar and Comal Counties, primarily to increase the simulated springflows to Comal and San Marcos Springs.
Initially, high drain conductance values were assigned for each simulated spring to allow unrestricted discharge of water $\left(1.00 \times 10^{6} \mathrm{ft}^{2} / \mathrm{d}\right.$ for Barton Springs [Scanlon and others, 2002]; $1.32 \times 10^{6} \mathrm{ft}^{2} / \mathrm{d}$ for springs in the San Antonio segment, derived from a very large hydraulic conductivity and the model cell dimensions). The drain conductances were adjusted during the steady-state calibration to match measured springflows to simulated springflows. As a result of the steady-state calibration, the drain conductance for San Pedro Springs was decreased by about two orders of magnitude, and the drain conductances for Comal and San Marcos Springs were increased by about a factor of two.

Revisions to simulated conduit segments (fig. 7) were made in Comal and Hays Counties during the steady-state calibration runs. One simulated conduit was deleted and one simulated conduit was added. The short southwest-northeasttrending simulated conduit segment immediately east of Hueco Springs was deleted by reducing the hydraulic conductivities of the conduit cells to magnitudes similar to those of the adjacent non-conduit cells. This was done to raise the simulated hydraulic heads in the area immediately to the west of the segment, which initially were much lower than the measured heads. Also, a simulated conduit segment was added connecting Comal and San Marcos Springs to increase simulated springflow at San Marcos Springs and lower simulated hydraulic heads immediately north and northeast of Comal Springs. Most of this added simulated conduit segment is aligned with Hunter channel (Maclay and Land, 1988, fig. 23), a narrow subsurface channel between major faults that contains extremely transmissive rocks.

\section{Goodness of Fit}

The steady-state simulation calibration results include a comparison of simulated hydraulic heads and springflows with average measured water levels and median springflows for 1939-46. The calibrated steady-state simulation generally reproduces the spatial distribution of measured water levels (pl. 2). Simulated hydraulic heads were within $30 \mathrm{ft}$ of measured water levels at 121 of the 144 wells used as targets for the steady-state simulation (table 8 at end of report). The difference was less than $20 \mathrm{ft}$ at 96 of the 144 wells. The largest difference between simulated and measured hydraulic heads was $106 \mathrm{ft}$ for a well in the confined zone in north-central Medina County. Residuals greater than $30 \mathrm{ft}$ occur in and near the recharge zone (unconfined conditions), southwest of the Bexar County index well (J-17, TWDB 6837203), in southern Comal County, and for single wells in north-central Medina County, northwestern and northeastern Bexar County, and northeastern Comal County. The large residuals (simulated minus measured heads) southwest of the Bexar County index well and in southern Comal County are positive and occur in the vicinity of the major simulated conduits and might indicate that the conduits are moving too much water (relative to the actual system) into these areas. The goodness of fit between simulated and measured hydraulic heads was quantified using the mean absolute 
difference, mean algebraic difference, and root mean square (RMS) error. The mean absolute difference between simulated and measured hydraulic heads, computed as the sum of the absolute values of the differences divided by the number of wells, is $19.4 \mathrm{ft}$ (table 8). The mean algebraic difference between simulated and measured hydraulic heads, computed as the algebraic sum of the differences divided by the number of wells, is $4.5 \mathrm{ft}$, indicating that positive differences were approximately balanced by negative differences. The graph of simulated relative to measured hydraulic heads indicates very little spatial bias in the steady-state simulation results (fig. 23).

The RMS error is derived from the residuals between the simulated and measured hydraulic heads, as given in equation 2 .

$$
R M S=\left[\frac{1}{n} \sum_{i=1}^{n}\left(h_{s}-h_{m}\right)^{2}\right]^{0.5}
$$

where

$R M S$ is the root mean square error [L],

$n$ is the number of calibration points,

$h_{s}$ is the simulated hydraulic head at point $i[\mathrm{~L}]$, and

$h_{m}$ is the measured hydraulic head at point $i$ [L].

The RMS error for the 144 target wells of the calibrated steadystate simulation is $26.5 \mathrm{ft}$. The RMS error indicates that, on average, the simulated hydraulic heads differ from the measured hydraulic heads by about $26 \mathrm{ft}$. This error represents about 4 percent of the total head difference across the model area (650 ft). For comparison, calibration guidelines adopted by the TWDB Groundwater Availability Modeling (GAM) program specify that the RMS error should be less than 10 percent of the total head difference across the model area (Texas Water Development Board, 2004).

The simulated springflows for Comal and San Marcos Springs for the calibrated steady-state simulation were within 3 and 13 percent of the median springflows for the two springs, respectively (table 9 at end of report). GAM calibration guidelines specify that simulated flows, such as springflow or streamaquifer leakage, should be within 10 percent of the measured flows. The combined simulated springflows for San Antonio and San Pedro Springs were 50 percent greater than the median measured springflows. However, their discharges probably reflect local hydrogeologic conditions. Little local-scale data were available for calibration of these two relatively small springs. The simulated springflow for Leona Springs was about twice the median measured springflow. However, this discrepancy probably is reasonable because the reported discharge for Leona Springs might not account for all the discharge from the Edwards aquifer to the Leona gravels (Green, 2004).

\section{Transient Simulation}

The transient simulation includes changes in ground-water storage over time that result from pumping and other hydraulic stresses. The distribution of aquifer storativity resulted, therefore, from the calibration of the transient simulation. Simulations during the final phases of steady-state calibration were

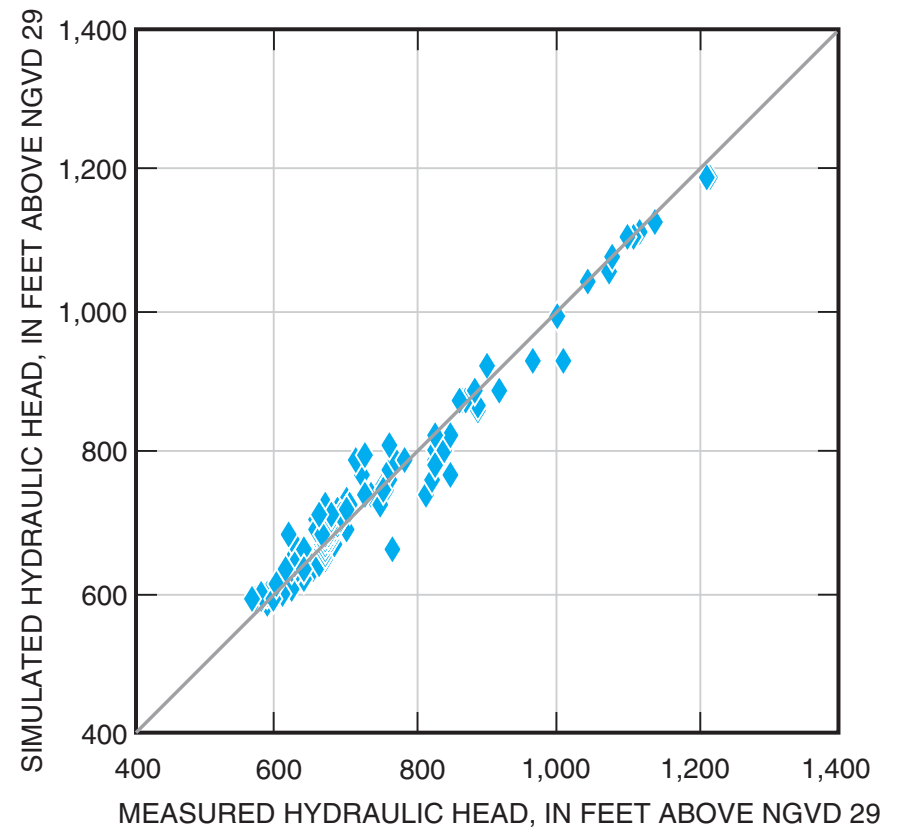

Figure 23. Simulated relative to measured hydraulic heads, steady-state simulation, Edwards aquifer model, San Antonio region, Texas.

alternated with transient runs, and adjustments were made to the appropriate input data until the final versions of both simulations were numerically consistent representations of the Edwards aquifer flow system. The transient calibration period for the Edwards aquifer model was 1947-90. The transient simulation also included a model testing period, 1991-2000, to establish greater confidence in the ability of the model to reproduce measured hydraulic heads and springflows. Comparatively minor adjustments to model parameters were needed for the model testing period simulation. The transient simulation used 648 monthly stress periods and a single time step per stress period. Multiple (as many as 10) time steps per stress period were used initially, but the number of time steps used was found to have no effect on the model results. Therefore, to minimize the length of the transient-simulation run times, only one time step per stress period subsequently was used.

\section{Calibration Targets}

The transient calibration targets included both a series of measurements of water level within a single well over time (hydrograph) and synoptic sets of water levels in multiple wells within comparatively short time periods (table 5). Only a few wells in the model area have periodic water-level measurements for the entire span of the transient calibration period, including the Bexar County and Uvalde County index wells. Many more wells in the model area, however, have periodic waterlevel measurements for some part of the transient calibration period. Wells with at least 10 years of periodic water-level 
measurements during the transient calibration period were considered as potential transient calibration targets. The goodness of fit between the simulated and measured hydrographs for selected wells, discussed later in the report, was used as a criterion for the transient model calibration.

Synoptic sets of water levels in multiple wells within comparatively short time periods also were used for the transient model calibration. Periods of below-normal and above-normal rainfall were selected to maximize the range of hydrologic conditions included in the transient calibration. The period of below-normal rainfall selected was August 1956, during the 1950s drought, when the lowest water levels of record were recorded. Water-level measurements from May 1956 through November 1956 were included as targets for the below-normal rainfall period to have a greater number and areal distribution of wells. However, most of the water-level measurements were for August 1956. Water-level measurements from a total of 171 wells were used as transient calibration targets for the belownormal rainfall period.

The period of above-normal rainfall selected was November 1974 through July 1975, a period of near record-high water levels in wells. Although most of the water-level measurements were for February 1975, the expansion of the time period of water-level measurements used was necessary to have a greater number and areal distribution of wells. Water-level measurements from a total of 169 wells were used as transient calibration targets for the above-normal rainfall period.

In addition to water levels in wells, springflows for Comal, San Marcos, Leona, San Antonio, and San Pedro Springs were used as targets for the transient model calibration. Springflows for time periods that lack measurements were estimated by straight-line interpolation from the available monthly data or relations to index wells.

\section{Changes From Initial Values}

The transient simulation was calibrated primarily by varying the simulated values of storativity, recharge rates, and drain altitude, and by the addition and deletion of conduit segments. The storativity values were varied within discrete zones during the transient calibration and testing, primarily on the basis of the magnitude of fluctuations for the applicable well hydrographs. The final calibrated storativity zones are shown in figure 24 . The storativity zones include five zones for specific yield, ranging from 0.005 to 0.15 , and five zones for specific storage, ranging from $5.0 \times 10^{-7}$ to $5.0 \times 10^{-6} \mathrm{ft}^{-1}$. The zones of highest specific storage are in the eastern (Barton Springs segment) and western (Kinney County) parts of the model area. The smallest specific storage is in the area generally south of the freshwater/ saline-water interface. The zones of highest specific yield are in the western part of the model area (Kinney and Uvalde Counties) and the Cibolo Creek and Dry Comal Creek recharge subzone (Comal County).

The areas of comparatively high storativity in Kinney and Uvalde Counties approximately coincide with the Maverick Basin. Hovorka and others (2004) hypothesized that the ratio of storage in matrix to storage in fractures and conduits might be higher in the western part of the San Antonio segment of the Edwards aquifer than in the more strongly karst-modified eastern area; if so, this might account for the need for higher simulated storativity in the Maverick Basin in Kinney and Uvalde Counties. The final calibrated storativities of the simulated conduit cells are the same as those for the non-conduit cells in the storativity zone in which the conduit cells occur. No distinction is made between conduit and non-conduit cells in the final calibrated storativities (fig. 24). The model calibration indicated that the simulated hydraulic heads and springflows are insensitive to the storativities assigned to the conduit cells.

The transient simulation indicated that the simulated hydraulic heads and water-level fluctuations (as shown in hydrographs) for periods of greatly above-normal rainfall and recharge were much greater than the corresponding measured hydraulic heads and water-level hydrograph fluctuations, particularly for wells in and near the recharge zone. For periods of below-normal to somewhat above-normal rainfall and recharge, however, the simulated hydraulic heads and water-level hydrograph fluctuations (figs. 15-17) reasonably matched the measured hydraulic heads and water-level fluctuations, using the calibrated storativity distribution shown in figure 24 . Therefore, assuming the storativity distribution is reasonable, the recharge rates for the periods of greatly above-normal rainfall and recharge were reduced. The simulated monthly recharge rates for the years 1958, 1973, 1981, 1987, 1991, and 1992 were multiplied by factors ranging from 0.60 to 0.85 (table 10 at end of report). The reported annual recharge amounts for these years were greater than 1,400,000 acre-ft. These factors and reduced simulated recharge rates (compared to the reported USGS estimated recharge rates) during years of greatly above-normal rainfall and recharge are consistent with the recharge rates reported by HDR Engineering, Inc., and Geraghty and Miller, Inc. (1991) and HDR Engineering, Inc. (1998). Their estimated annual recharge rates averaged as much as 45.3 percent less by recharge subzone than the corresponding USGS recharge estimates for the period 1934 through 1989, with the largest differences occurring during wet years, as previously discussed in the "Ground-Water-Flow System: Recharge" section of the report. Results and conclusions reported by HDR Engineering, Inc., for the period 1990-96 were similar. An additional reduction in simulated recharge, relative to USGS reported recharge estimates, during the transient simulation was for the Cibolo Creek and Dry Comal Creek recharge subzone (fig. 20). The USGSreported recharge rates were reduced by 50 percent for all stress periods for the transient simulation. Reasons why the USGS estimates of recharge for the Cibolo Creek and Dry Comal Creek recharge subzone might be too high were discussed previously in the "Ground-Water-Flow System: Recharge" section of the report.

Much of the focus of a model of the Edwards aquifer is the ability to simulate the cessation of springflow. Therefore, during the transient calibration the drain altitudes for Comal and San Marcos Springs were raised above the land-surface altitude of the lowest spring orifice. This revision of drain altitudes is 


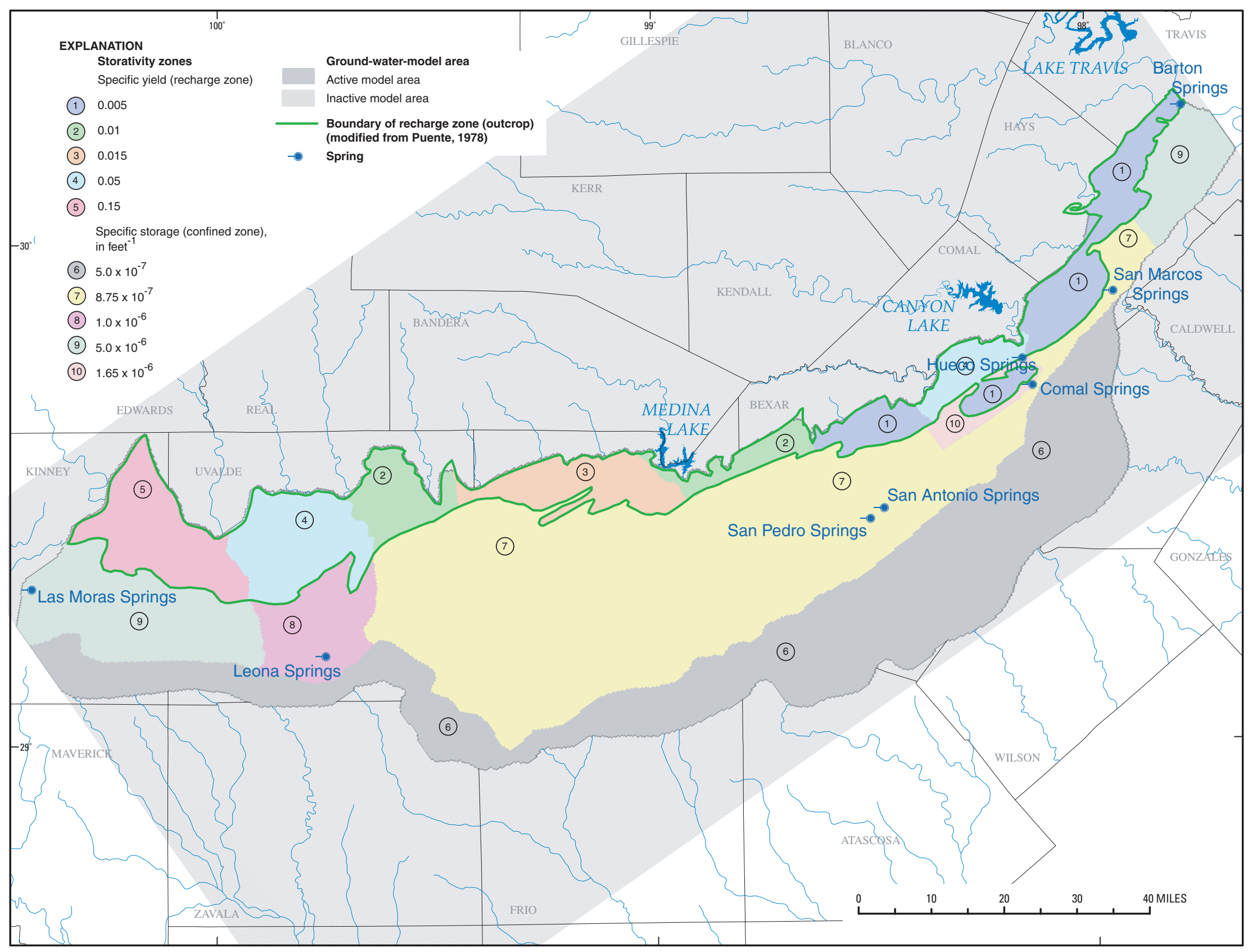

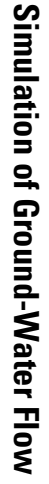

Figure 24. Simulated storativity zones for calibrated Edwards aquifer model, San Antonio region, Texas. 
consistent with (1) a very steep hydraulic gradient in the immediate vicinity of the springs, where most of the hydraulic-head loss occurs, and (2) a model cell size of $0.25 \mathrm{mi}(1,320 \mathrm{ft})$. The MODFLOW drain package requires a decline in the simulated hydraulic head in the cell containing the spring to an altitude at or below the simulated drain altitude for the simulated springflow to be zero. This means that the average head in the cell containing the drain has to be at or below the drain altitude. However, with a model cell size of $1,320 \mathrm{ft}$ combined with the assumption that most of the head loss occurs in the immediate vicinity of the spring, the average head in the model cell will not be the same as the drain altitude at the time the spring must cease to flow to match observed historical (or hypothetical future) conditions. The average head in the model cell will always be higher than the simulated drain altitude during periods when zero simulated springflow must occur to match actual conditions. Therefore, the simulated drain altitude was treated as a calibration parameter and varied during the transient model calibration to match periods of zero springflow. The "effective" drain altitude that would produce zero springflow would be the same as the land-surface altitude of the spring orifice only if the model cell size was approximately the same size as the spring orifice.

The drain altitude for Comal Springs was incrementally raised during the transient calibration until a period of simulated zero discharge for Comal Springs was achieved approximating the period of observed zero discharge. The final calibrated "effective" drain altitude for Comal Springs is $609 \mathrm{ft}$, which is $26 \mathrm{ft}$ higher than the initial simulated drain altitude (table 11 at end of report). The altitude of the lowest spring orifice for Comal Springs is not known, but it might be as low as $600 \mathrm{ft}$ on the basis of topographic map altitudes. In order to maintain the same gradient between the orifices for Comal and San Marcos Springs, the simulated drain altitude for San Marcos Springs also was raised $26 \mathrm{ft}$ above the initial simulated drain altitude, from 558 to $584 \mathrm{ft}$. As is characteristic of Comal Springs, steep hydraulic gradients exist in the immediate vicinity of San Marcos Springs. The simulated drain altitudes for the other simulated springs were not changed during model calibration (table 11). Reasonable matches between simulated and measured periods of zero discharge for Leona, San Antonio, and San Pedro Springs were achieved without changing the initial simulated drain altitudes, probably because hydraulic gradients are less steep in the immediate vicinity of these springs.

The drain conductances for the five springs used as model calibration targets further were refined (subsequent to the steady-state calibration adjustments previously described) during transient calibration to more closely match measured values of springflow. The final calibrated drain conductances for Comal, San Marcos, and San Antonio Springs were increased from their initial values, and those for Leona and San Pedro Springs were decreased (table 11). The simulated drain conductances for Barton and Las Moras Springs were not changed from their initial values because they were not used as model calibration targets.
During the transient calibration, revisions were made to the simulated conduit segments. Two segments were added and one segment was deleted to more closely match measured hydraulic heads and springflows (fig. 7). The added segments were (1) a segment linking Leona Springs with the segment that loops northeastward through Uvalde County and (2) a short extension of the original segment trending northeastward from San Marcos Springs. The addition of the Leona Springs segment is justified by the observation of Hovorka and others (2004) that wells with no measurable drawdown (during specific-capacity tests) occur in disproportionate numbers near Leona Springs and along a zone trending northwest from them; a network of conduits was inferred from the available data. The conduit segment trending northeastward from San Marcos Springs was extended to the vicinity of the ground-water divide near Kyle to increase simulated springflow at San Marcos Springs and also to lower simulated hydraulic heads in the vicinity of the divide. The deleted segment was the northwestsoutheast-trending segment in southeastern Uvalde and northwestern Frio Counties. The inclusion of this conduit segment (with large hydraulic conductivities) resulted in excessive ground-water flow from the western part of the model area (Kinney and Uvalde Counties) to the eastern part. With this segment included, simulated hydraulic heads and springflows were appreciably lower than measured hydraulic heads and springflows in Kinney and Uvalde Counties and correspondingly higher than the measured hydraulic heads and springflows in Medina, Bexar, and Comal Counties.

Minor adjustments also were made to the simulated hydraulic conductivities during the transient calibration, particularly in the recharge zone, in Kinney and southern Uvalde Counties, and for some of the conduit segments. Calibration of the transient simulation for periods of greatly above-normal rainfall and recharge resulted in increases in hydraulic conductivities for parts of the recharge zone and for some conduits originating in the recharge zone, to avoid simulated hydraulic heads above land surface during these periods. This upward revision of hydraulic conductivities was most prevalent in Kinney, Uvalde, and Medina Counties. Adjustments also were made to storativities to avoid simulated hydraulic heads above land surface, in conjunction with and constrained by the need to simulate the temporal fluctuations observed in target well hydrographs. In some areas where hydraulic conductivities were increased in the recharge zone, a corresponding lowering of the layer bottom altitudes was needed to prevent model cells from going dry during periods of below-normal rainfall and recharge, such as the 1950 s drought. Further minor revisions to storativities and hydraulic conductivities were needed for the testing period simulation because of the period-of-record high annual recharge during 1992. Additional increases in storativities and hydraulic conductivities in some areas of the recharge zone were required to prevent simulated hydraulic heads from rising above land surface during the 1992 period of very high simulated recharge. The final calibrated hydraulicconductivity and transmissivity distributions for the Edwards aquifer model are shown in figures 25 and 26. A summary of the 


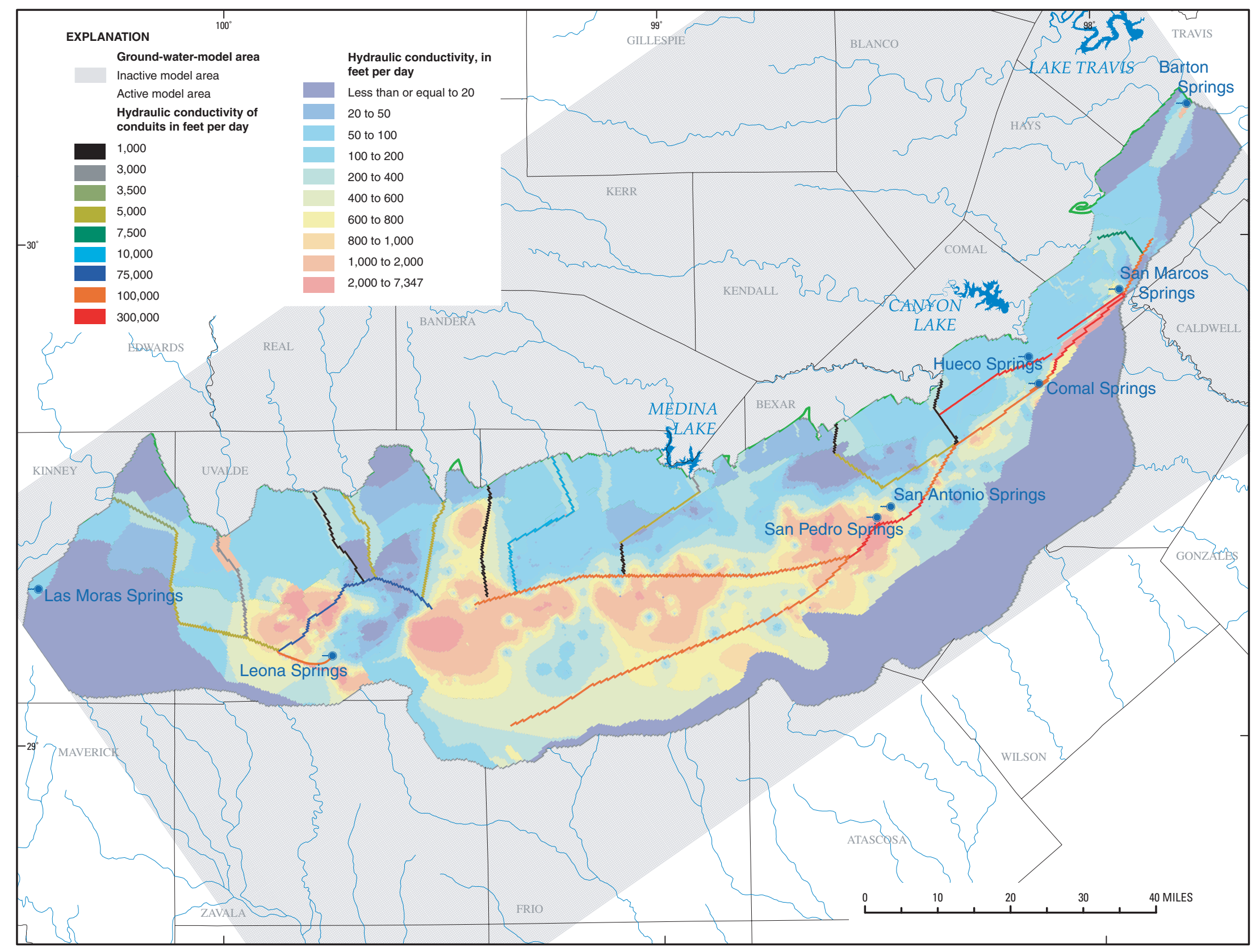

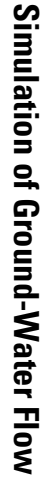

Figure 25. Simulated distribution of horizontal hydraulic conductivity for calibrated Edwards aquifer model, San Antonio region, Texas. 


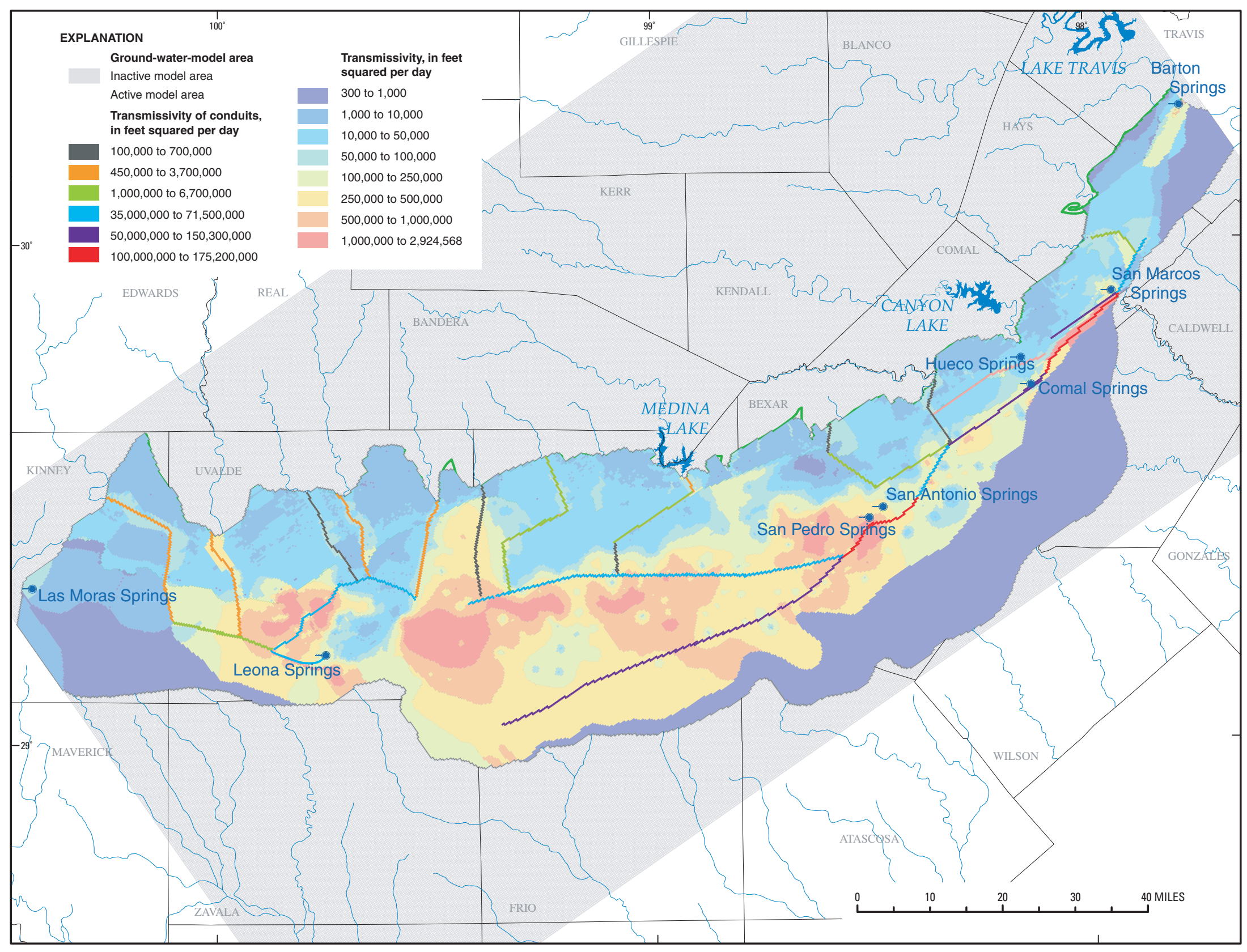

Figure 26. Simulated distribution of transmissivity for calibrated Edwards aquifer model, San Antonio region, Texas. 
changes from the calibrated steady-state simulation, and revisions to the initial, uniform values for storativity, needed for the calibrated transient simulation is shown in table 12 (at end of report).

\section{Goodness of Fit}

The transient simulation results include a comparison of simulated hydraulic heads with synoptic sets of water levels in multiple wells during periods of below-normal and abovenormal rainfall, as well as a series of measurements of water level within a single well over time (hydrograph). The final transient simulation generally reproduces the spatial distribution of measured water levels for the period of drought conditions (pl. 3). Quantitative measures of goodness of fit between simulated and measured hydraulic heads (mean absolute difference, mean algebraic difference, and RMS error) were computed for the periods of below-normal and above-normal rainfall. The closest-match simulated hydraulic heads for the period of below-normal rainfall (May 1956-November 1956) were within $30 \mathrm{ft}$ of measured water levels at 140 of the 171 wells for which water-level data were available (table 13 at end of report). The difference was less than $20 \mathrm{ft}$ at 125 of the 171 wells. Differences were greater than $100 \mathrm{ft}$ for 7 of the wells, and the largest difference was $289 \mathrm{ft}$ for a well in the recharge zone in Uvalde County. The other 6 wells with differences greater than $100 \mathrm{ft}$ are in or near the recharge zone in Uvalde, Medina, and Bexar Counties. Residuals were commonly greater than $30 \mathrm{ft}$ in the recharge zone. Residuals greater than $30 \mathrm{ft}$ also occurred near the recharge zone in north-central Uvalde County, north-central Medina County, and northcentral Bexar County and for randomly located wells in eastern Kinney County, eastern Uvalde County, eastern Bexar County, and south-central Hays County. The randomly located wells with large residuals generally are near wells with smaller (less than $30 \mathrm{ft}$ ) residuals and, therefore, the large residuals are anomalous and might be caused by local hydrogeologic conditions not represented in the Edwards aquifer model. The mean absolute difference between simulated and measured hydraulic heads is $23.0 \mathrm{ft}$. The corresponding mean algebraic difference is $-11.0 \mathrm{ft}$, which might indicate a small bias toward simulated hydraulic heads too low during periods of drought conditions. The graph of simulated relative to measured hydraulic heads indicates little spatial bias in the simulation results for the period of drought conditions (fig. 27a). The RMS error is $45.5 \mathrm{ft}$. This error represents about 6 percent of the total head difference across the model $(712 \mathrm{ft})$.

The final transient simulation generally reproduces the spatial distribution of measured water levels for the period of above-normal rainfall (pl. 4). The closest-match simulated hydraulic heads for the period of above-normal rainfall (November 1974 through July 1975) were within $30 \mathrm{ft}$ of measured water levels at 129 of the 169 wells for which water-level data were available (table 14 at end of report). The difference was less than $20 \mathrm{ft}$ at 93 of the 169 wells. Differences were greater than $100 \mathrm{ft}$ for two wells in the recharge zone, and the largest difference was $165 \mathrm{ft}$. Multiple wells with residuals greater than $30 \mathrm{ft}$ occur in and near the recharge zone in eastern Uvalde County and south-central Bexar County. The large residuals in eastern Uvalde County and south-central Bexar County are positive and occur near the major simulated conduits and might indicate that the conduits are moving too much water into these areas. Randomly located wells with relatively large residuals (greater than $30 \mathrm{ft}$ ) occur in central Uvalde County, northeastern Medina County, and northwestern and north-central Bexar County. The mean absolute difference between simulated and measured hydraulic heads is $23.5 \mathrm{ft}$. The corresponding mean algebraic difference is $3.5 \mathrm{ft}$, which indicates that positive differences were approximately balanced by negative differences. The graph of simulated relative to measured hydraulic heads indicates little spatial bias in the simulation results for the period of above-normal rainfall and recharge, other than possibly a bias toward low simulated hydraulic heads in the range of measured heads from about 975 to $1,075 \mathrm{ft}$ (fig. 27b). This range in measured hydraulic heads corresponds with target wells in the Nueces-West Nueces River and FrioDry Frio River recharge subzones. The RMS error is $33.5 \mathrm{ft}$. This error represents about 5 percent of the total head difference across the model area $(663 \mathrm{ft})$.

The RMS error for the period of drought conditions was $45.5 \mathrm{ft}$ and for the period of above-normal rainfall and recharge was $33.5 \mathrm{ft}$ (tables 13, 14). As indicated by the mean algebraic difference between simulated and measured hydraulic heads, the model might tend to simulate lower-than-measured hydraulic heads during periods of below-normal rainfall (algebraic mean, -11.0 ft) and, to a lesser degree, higher-than-measured hydraulic heads during periods of above-normal rainfall (algebraic mean, $3.5 \mathrm{ft}$ ). In general, the model provides a reasonable, conservative simulation of water levels for varying hydrologic conditions.

The transient calibration results also include a comparison of simulated springflows and hydraulic heads with a series of measurements of springflow and of water levels within individual wells over time (hydrograph). Hydrographs comparing simulated and measured hydraulic heads for 11 target wells and springflows for five springs, are included in this report. The 11 target wells are distributed throughout the model area and are representative of the results of the transient simulation. The transient simulation for 1947-2000 acceptably reproduces measured fluctuations in hydraulic heads over time in the Edwards aquifer (figs. 15-17). The match between simulated and measured hydraulic heads generally is closer for wells completed in the confined part of the aquifer than for those in and near the recharge zone. The RMS error ranged from 4.1 to $23.2 \mathrm{ft}$ in 11 wells with water-level measurements for varying periods during 1947-2000, and these errors represent 7.8 to 30.8 percent of the range in water-level fluctuations of each of those wells. The smallest RMS error was for well 6816801 in Comal County (4.1 ft) and the largest was for well 6845102 in south-central Bexar County $(23.2 \mathrm{ft})$.

Generally acceptable agreement also was obtained between simulated and measured flow at the simulated springs (figs. 28-29). The RMS errors for Comal, San Marcos, Leona, 
(a)

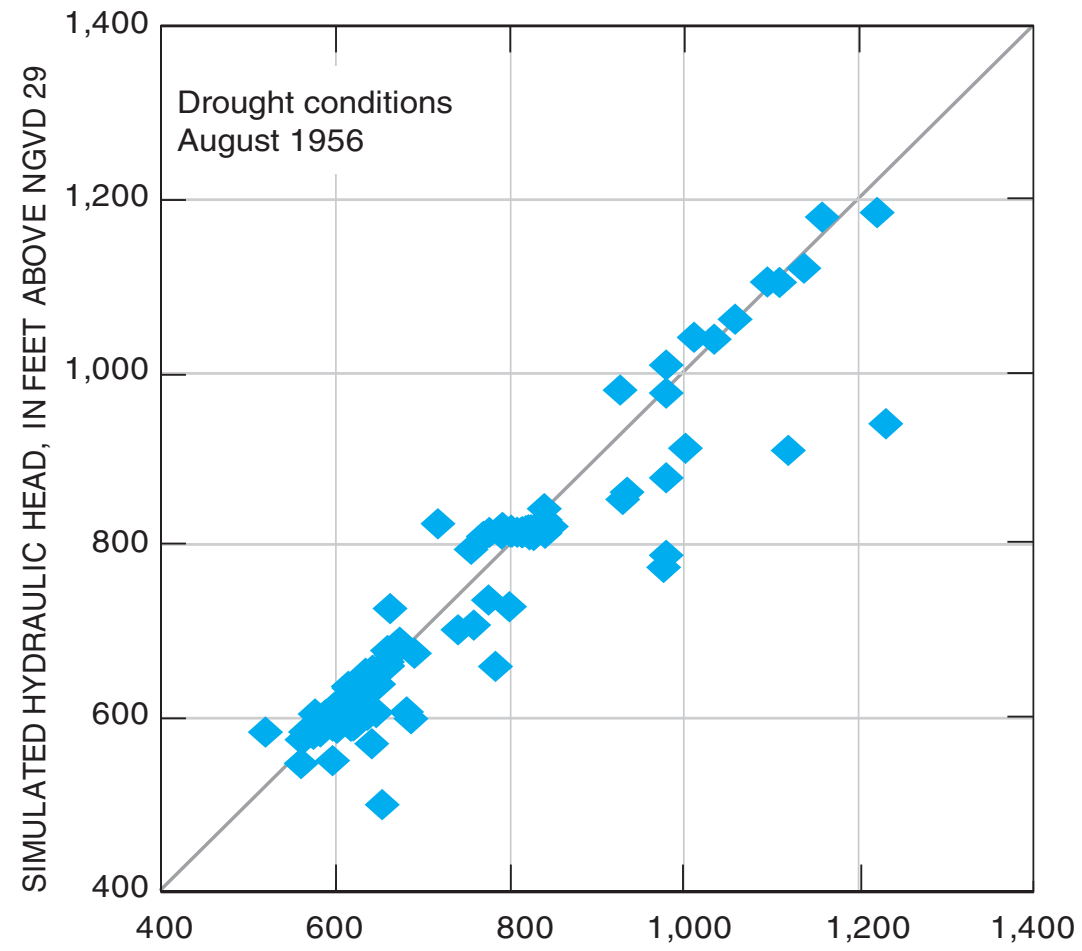

MEASURED HYDRAULIC HEAD, IN FEET ABOVE NGVD 29

(b)

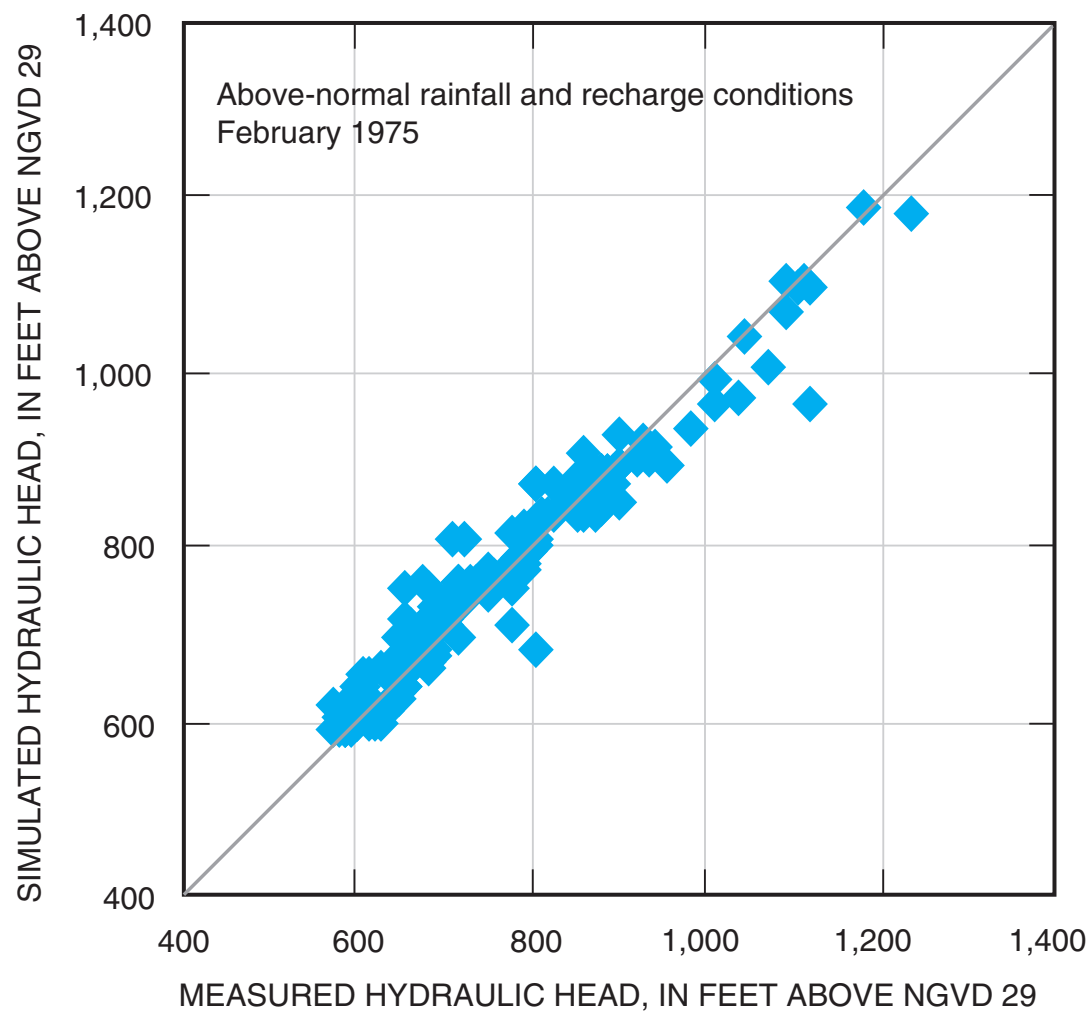

Figure 27. Simulated relative to measured hydraulic heads for (a) August 1956 (stress period 117) and (b) February 1975 (stress period 339), transient simulation, Edwards aquifer model, San Antonio region, Texas. 
(a)

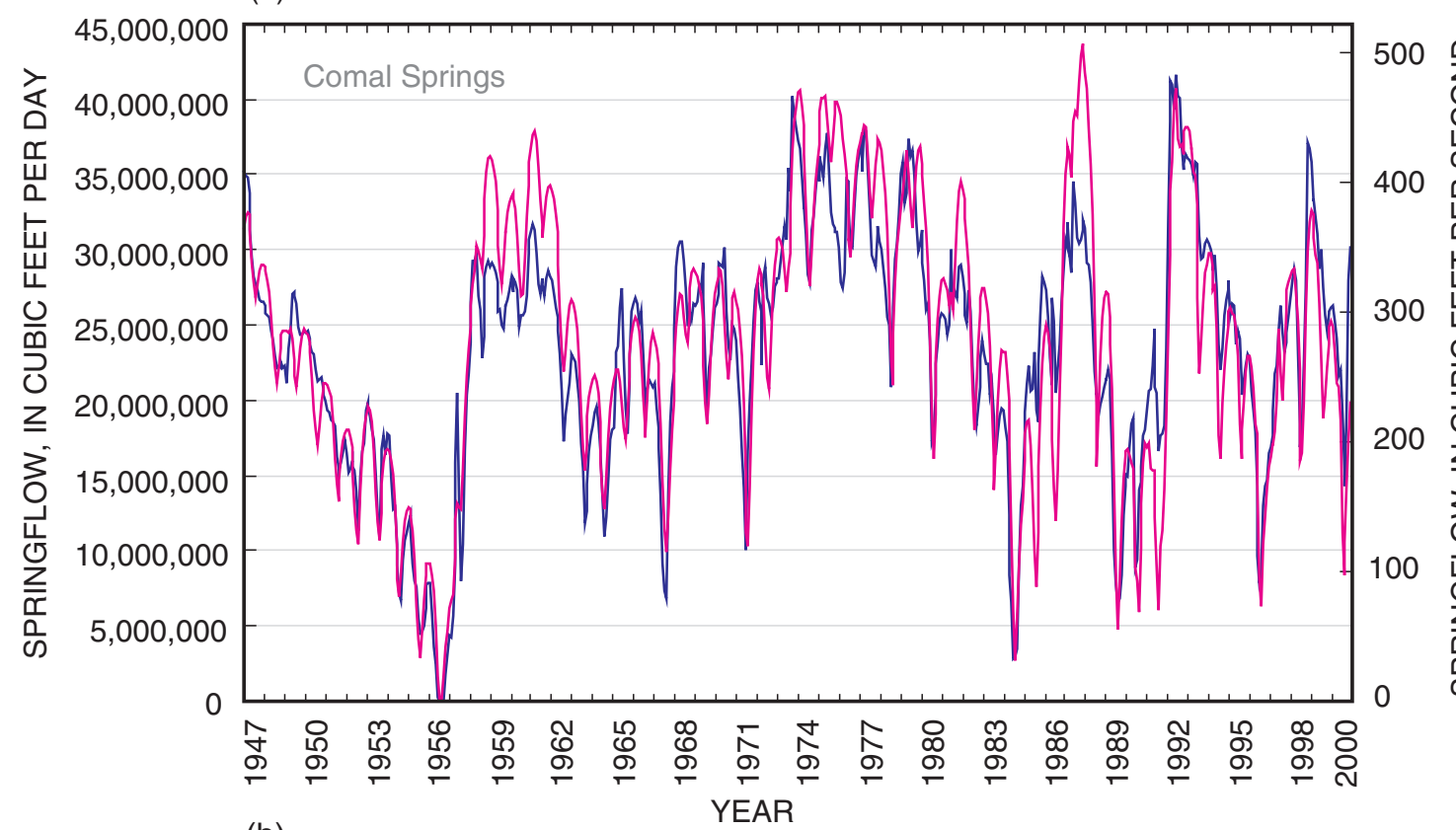

EXPLANATION Springflow

(b)

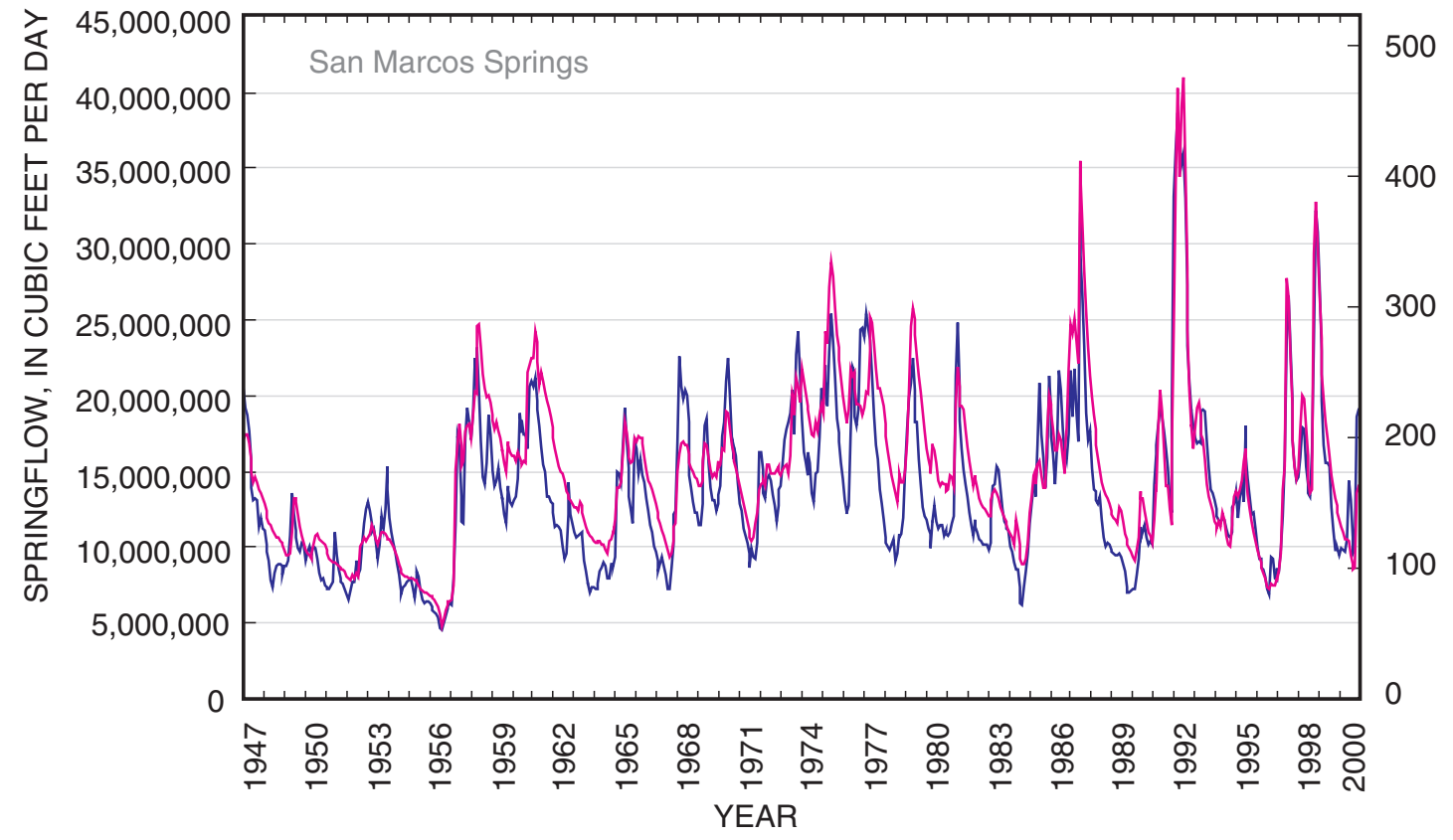

EXPLANATION Springflow - Measured 㟒- Simulated

Figure 28. Measured and simulated springflows for (a) Comal Springs and (b) San Marcos Springs, 1947-2000, Edwards aquifer model, San Antonio region, Texas.

San Antonio, and San Pedro Springs ranged from 230,700 cubic feet per day $\left(\mathrm{ft}^{3} / \mathrm{d}\right)\left(2.7 \mathrm{ft}^{3} / \mathrm{s}\right)$ for San Pedro Springs to $3,967,000$ $\mathrm{ft}^{3} / \mathrm{d}^{(}\left(45.9 \mathrm{ft}^{3} / \mathrm{s}\right)$ for Comal Springs. The RMS errors for the five springs, as a percentage of the range of springflow fluctuations measured at the springs, varied from 7.0 percent for San Marcos Springs to 36.6 percent for Leona Springs and were less than 10 percent for all but Leona Springs. The mean algebraic differences between simulated and measured springflows are 6.7 and $15.0 \mathrm{ft}^{3} / \mathrm{s}$ for Comal and San Marcos Springs, respectively, indi- cating a small bias in the residuals toward high flows. Simulated high flows during 1958-61 and the late 1980s for Comal Springs are somewhat greater than the measured high flows (fig. 28a). However, for San Marcos Springs and during other periods of measured high flows for Comal Springs, the simulated and measured springflows generally are in close agreement. The recessions in simulated flows for San Marcos Springs generally are more gradual than are those in the measured data, and for some time periods the simulated lows in the recessions 
(a)

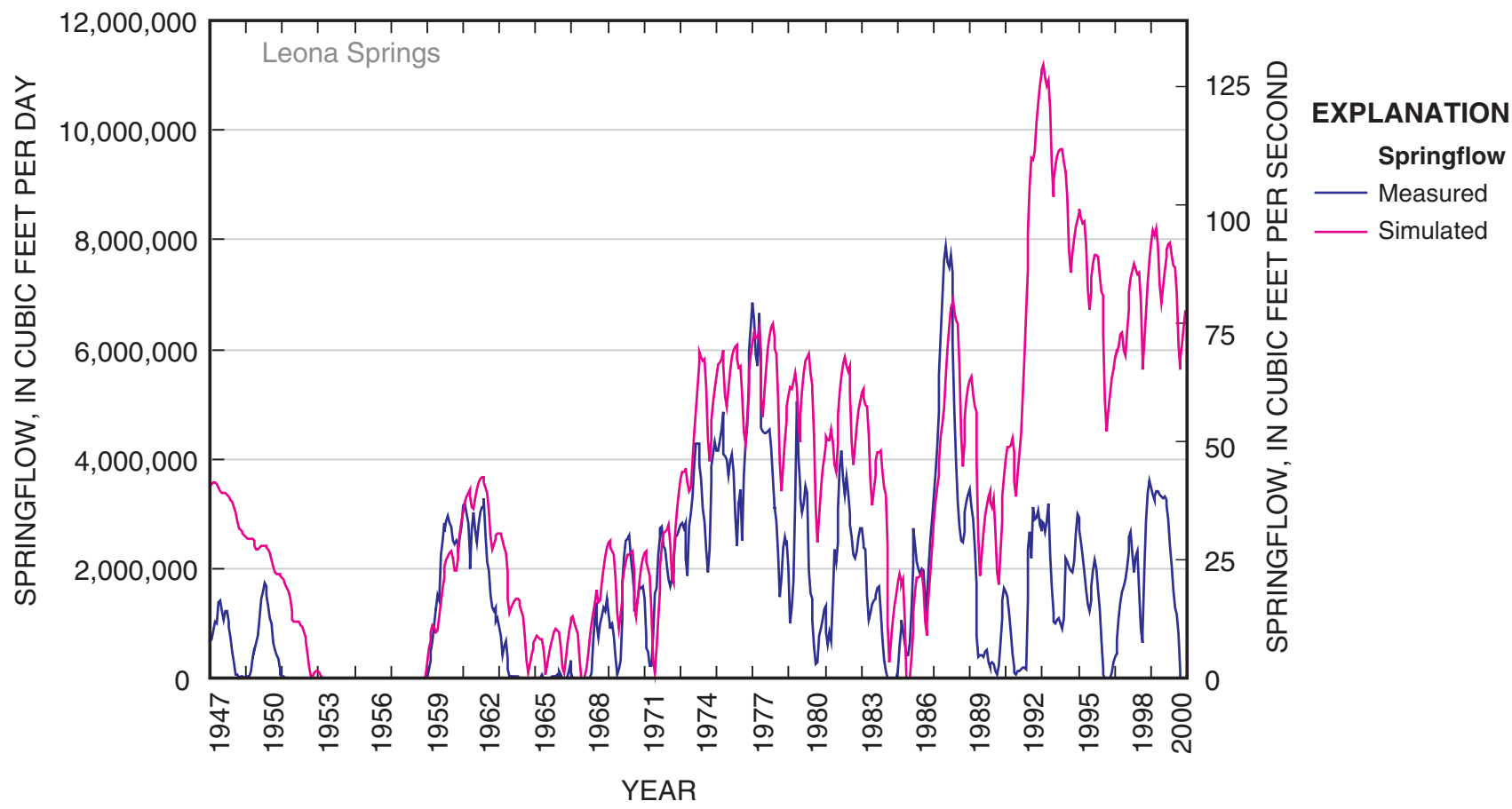

(b)

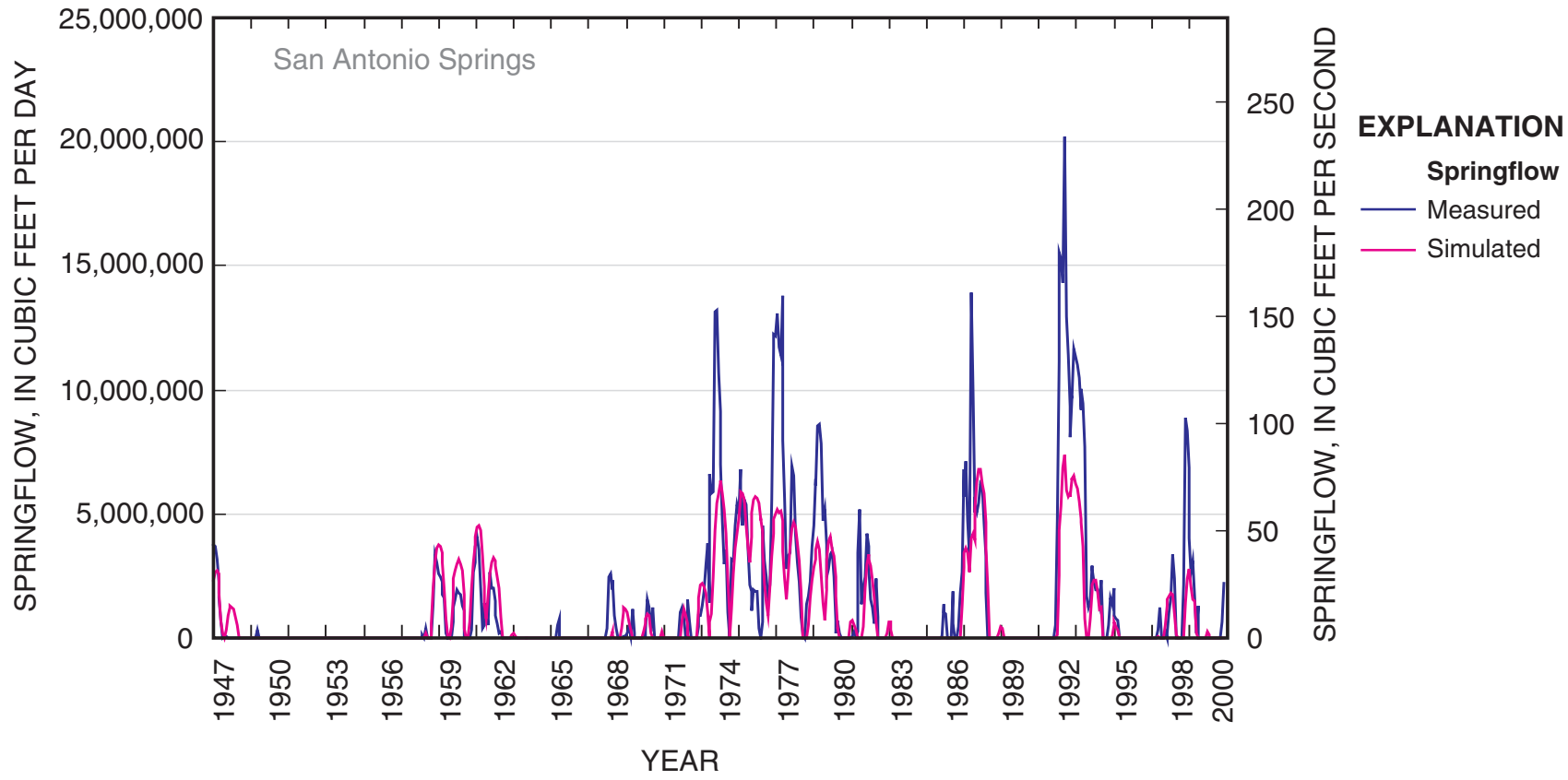

Figure 29a, b. Measured and simulated springflows for (a) Leona Springs, (b) San Antonio Springs, 1947-2000, Edwards aquifer model, San Antonio region, Texas.

do not reach the measured lows. Therefore, the simulated springflows tend to overestimate the measured springflows during many low-flow periods, with the resulting relatively high mean algebraic difference. The simulated spring discharge for Leona Springs generally is greater than the measured discharge and is anomalously high following the very large recharge events of the early 1990s (fig. 29a). However, as previously noted, reported discharge for Leona Springs might appreciably underestimate the actual discharge because of unmeasured discharge from the Edwards aquifer to the Leona gravels. The 
(c)

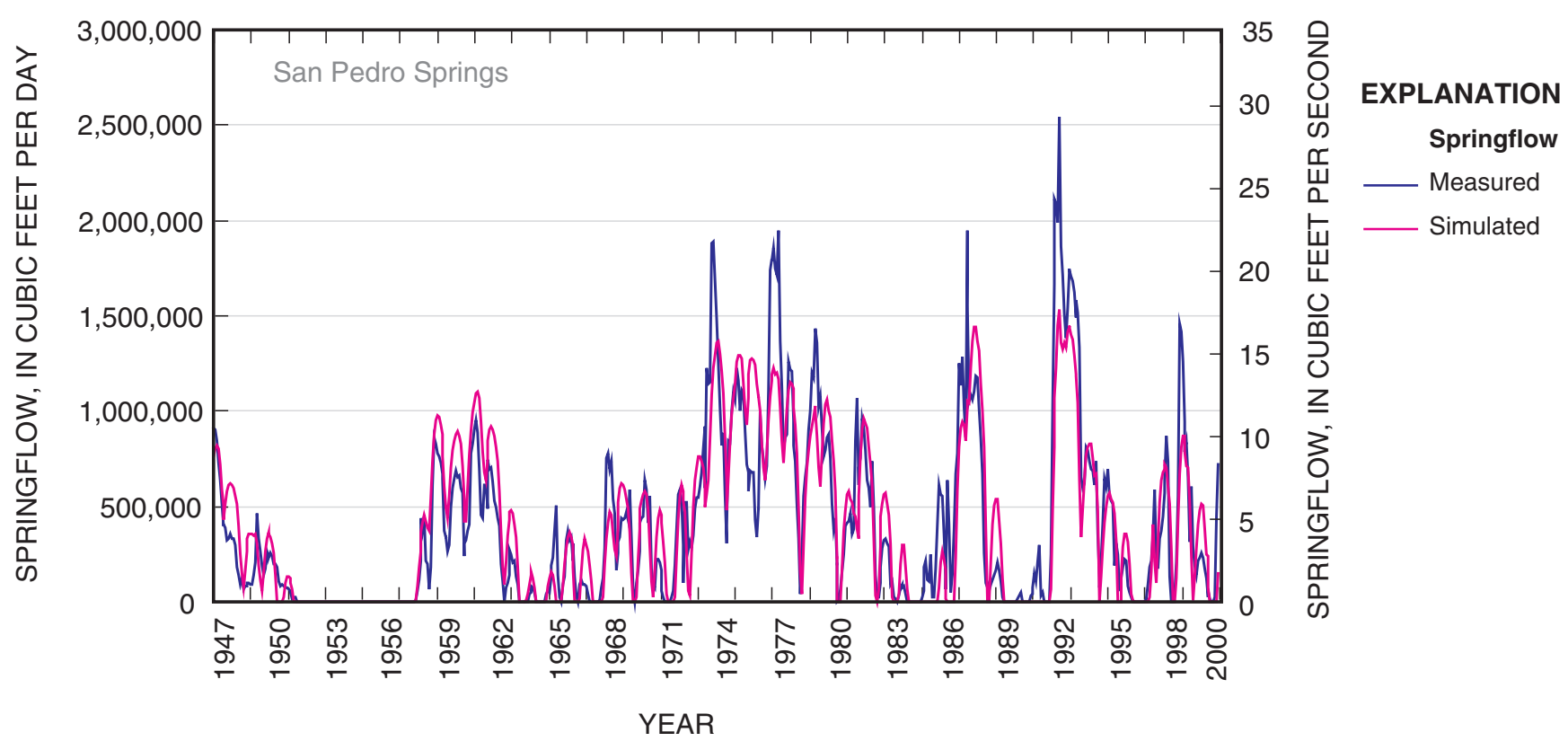

Figure 29c. Measured and simulated springflows for San Pedro Springs, 1947-2000, Edwards aquifer model, San Antonio region, Texas.

simulated springflow for San Antonio and San Pedro Springs underestimate the measured springflow during peak discharge periods (fig. 29). In general, the model reasonably simulates springflows for different hydrologic conditions, with the match closer for Comal Springs than for San Marcos Springs.

\section{Numerical Model Results}

Model output from the Edwards aquifer model includes simulated hydraulic heads, cell-by-cell flows, and water budgets. The simulated hydraulic heads are spatially and, for transient simulations, temporally distributed. Simulated hydraulic heads are calculated by the model for each active model cell for each stress period. The simulated hydraulic heads can be saved in a MODFLOW output text file or a binary heads file. The saved hydraulic heads can be used by model postprocessors to plot and contour the areal distribution of hydraulic heads (potentiometric surface) or to plot ground-water-flow directions.

\section{Ground-Water Flow}

The directions of flow in the Edwards aquifer, based on velocity vectors computed by the Groundwater Vistas software (Environmental Simulations, Inc., 2002), for periods representing steady-state, drought, and above-normal recharge conditions are shown on plates 5-7, respectively. These plates show that directions of flow in the model are strongly influenced by the presence of simulated conduits and barrier faults. The major components of regional ground-water flow are (1) from the recharge zone southward into the confined zone and (2) from west to east in the confined zone toward the major springs (Comal and San Marcos Springs in San Antonio segment of the aquifer; Barton Springs in Barton Springs segment). A ground-water divide occurs near Kyle in south-central Hays County, from which ground-water flow is to the east toward Barton Springs or to the west toward San Marcos Springs. The position of this ground-water divide varies, depending on the water-level conditions, as indicated by the flow-direction arrows on plates 5-7. For steady-state and above-normal rainfall and recharge conditions, the position of the ground-water divide is coincident with its commonly defined position near Kyle (pls. 5, 7). Within the Onion Creek recharge subzone, Onion Creek serves as an approximate dividing line between water moving westward toward San Marcos Springs and water moving eastward toward Barton Springs. In contrast, during drought conditions the position of the groundwater divide shifts westward to near San Marcos Springs, and recharge from the Blanco River moves eastward toward Barton Springs, rather than westward toward San Marcos Springs (pl. 6).

The structures that influence ground-water flow can be divided into two groups- those that tend to convey flow (for example, gaps in geologic structures and grabens) and those that tend to restrict flow (for example, barrier faults and horsts) (Maclay and Land, 1988). The simulated flow in the Edwards aquifer model is strongly influenced by the locations of the conduits, which tend to convey flow. Conduits are interpreted to be major contributors to flow in the Edwards aquifer, with most of 
the flow occurring through fractures and conduits, rather than through the rock matrix (Hovorka, Mace, and Collins, 1998; Hovorka and others, 2004; Worthington, 2004). The importance of flow by conduits is reflected in the simulated subregional flow directions in the Edwards aquifer model. The simulated flow directions generally are toward the nearest conduit and subsequently along the conduits from the recharge zone into the confined zone and toward the major springs.

The simulated flow directions indicate the predominantly southward flow through the Knippa gap in eastern Uvalde County. The Knippa gap is a narrow opening within an extensive, complex system of barriers to flow that includes the combination of horsts and a major fault (Maclay and Land, 1988). Through this opening, ground water flows from the western storage unit and the western Medina storage unit (Maclay, 1995, table 5) southward and downdip toward the southernmost part of the aquifer in southeastern Uvalde and southwestern Medina Counties. Initially, a conduit was simulated in the Edwards aquifer model in the Knippa gap area (fig. 7). However, model calibration indicated that the presence of a conduit segment with a large horizontal hydraulic conductivity resulted in the conveyance of too much water through the Knippa gap area, and therefore, this segment was deleted from the model.

Structures simulated in the Edwards aquifer model influencing ground-water flow that tend to restrict flow include barrier faults. The influence of simulated barrier faults on flow directions is most evident in northern Medina County (pls. 5-7). In this area, the direction of ground-water flow is affected primarily by parallel northeastward-striking faults (fig. 5) that divert flow toward the southwest. The steep regional slope of the potentiometric surface is toward the southeast, but these faults, as local barriers to southeastward flow, divert the flow toward the southwest. In the Edwards aquifer model, flow along some segments of these northern Medina County barrier faults is enhanced by conduit segments coinciding with the fault locations, which convey flow along, rather than across, the fault segments. Water-level altitudes change abruptly across segments of the major faults in some areas, in particular in northeastern Medina and north-central Bexar Counties (pls. 2-4). Comparatively large hydraulic-head changes across faults also are indicated by the deflection of simulated potentiometricsurface contours along faults in the confined zone of the Edwards aquifer, as seen on plates 2-4, for example, in southwestern Bexar and southwestern Medina Counties.

\section{Water Budget}

In addition to hydraulic heads, the water budget for the model is computed for each stress period. A water budget in the context of the model is an accounting of inflow to, outflow from, and storage change in the aquifer. For steady-state conditions, inflow (sources) to the aquifer equals outflow (discharges) from the aquifer. For transient conditions, changes in storage likely occur. For a balanced transient water bud- get-that is, total sources equal total discharges equal total flow through the aquifer-positive changes (gains) in storage must be included as discharges, and negative changes (losses) in storage must be included as sources. Sources of water to the Edwards aquifer include (1) recharge from leakage from streams and infiltration of rainfall in the recharge zone and (2) inflow across the northern and northwestern model boundaries (fig. 30). Also, a small amount of leakage from the Colorado River to the aquifer occurs during periods of low water levels. Discharge from the Edwards aquifer includes (1) springflow (drain discharge), (2) withdrawals by wells, and (3) leakage to the Colorado River from the aquifer (fig. 30).

\section{Steady-State Simulation}

The steady-state simulation water budget indicates that recharge accounts for 93.5 percent of the sources of water to the Edwards aquifer and inflow through the northern and northwestern model boundaries contributes 6.5 percent (fig. 30; table 15 at end of report). Most of the flow into the model area through the northern and northwestern model boundaries occurs through the northern boundary (87.9 percent). The largest discharges from the Edwards aquifer in the steady-state simulation water budget are springflow (73.7 percent) and withdrawals by wells (25.7 percent). Discharge from the aquifer to the Colorado River is a minor component of the steady-state budget (0.6 percent).

\section{Transient Simulation}

The simulated water budgets for the transient simulation for 1956 and 1975 are shown in figures 30 and 31 and in table 15. In figure 31 and table 15, positive changes (gains) in storage for stress periods are included as discharges, and negative changes (losses) in storage are included as sources. This convention is consistent with making the water budget (total sources equal total discharges equal total flow through the aquifer) balance. The 1956 water budget represents drought conditions and the 1975 water budget represents above-normal rainfall and recharge conditions. The principal source of water to the Edwards aquifer (excluding change in storage) for the transient simulation is recharge, constituting about 60 percent of the sources of water to the Edwards aquifer during 1956, a drought period, and about 97 percent of the sources (excluding change in storage) during 1975, a period of above-normal rainfall and recharge (table 15). Inflow through the northern and northwestern model boundaries contributed a relatively small amount of water. Subsurface inflow through the northern and most of the northwestern model boundaries was simulated as a constant flux, and therefore minimal variations occur on a monthly and annual basis. Although the amount of water contributed by boundary inflow was relatively small, it constituted about 39 percent of the sources (excluding change in storage) to the aquifer during 1956, because of the greatly reduced recharge during this drought period (table 15). A very small amount of leakage from the Colorado River to the aquifer occurred during 1956, but not during 1975 (table 15). This was 


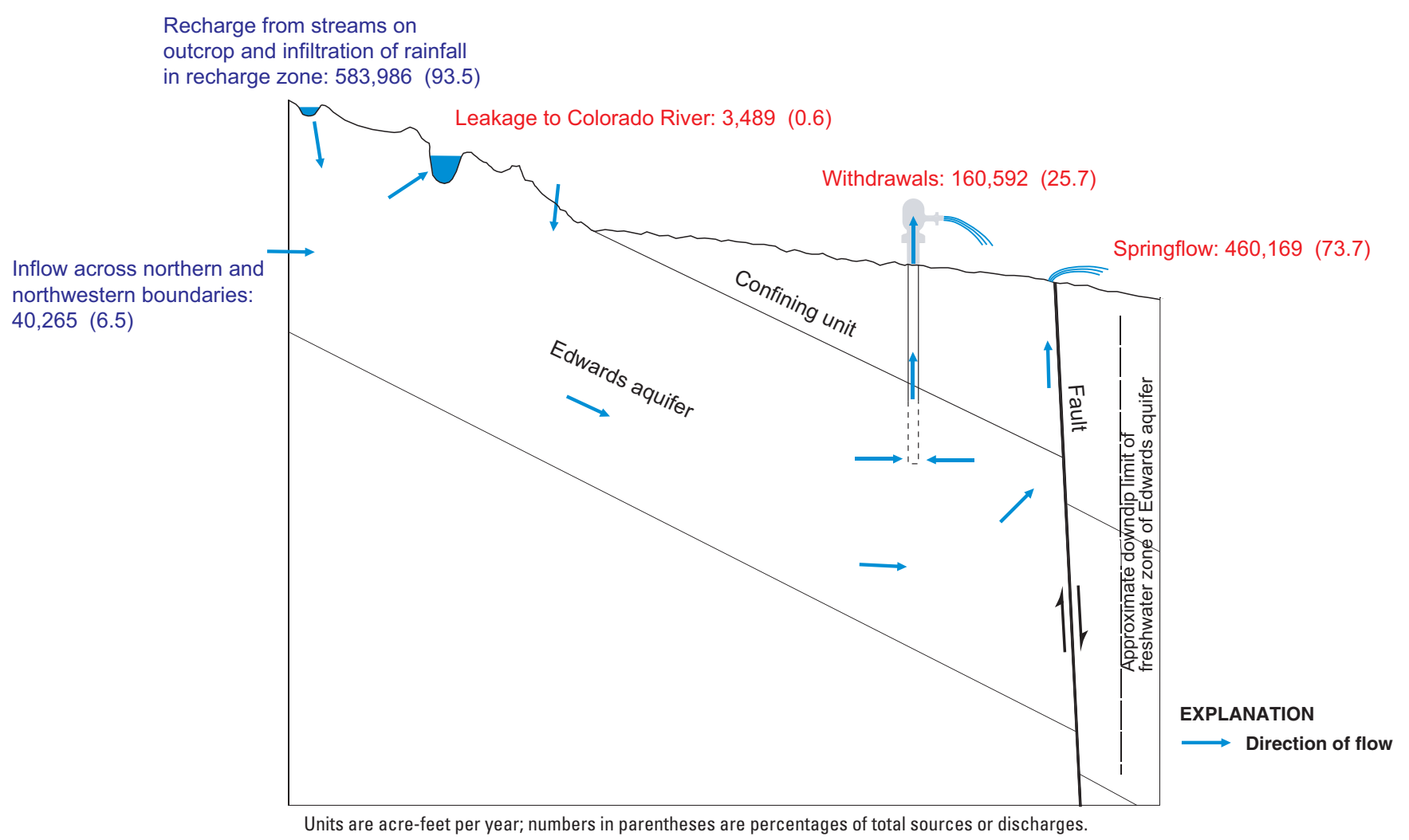

(a) Steady-state simulation

Drought year Wet year

(1956)

(1975)

\begin{tabular}{|l|r|r|}
\hline & & \\
Recharge & $+60,460$ & $+1,063,225$ \\
Boundary inflow & $+39,457$ & $+37,463$ \\
Springflow & $-104,984$ & $-674,870$ \\
Withdrawals & $-309,178$ & $-327,024$ \\
Net stream-aquifer leakage & $-1,692$ & $-4,187$ \\
Net change in storage & $+315,940$ & $-94,600$ \\
\hline
\end{tabular}

Units are acre-feet; + is source of water to aquifer; - is discharge of water from aquifer.

(b) Transient simulation

Figure 30. Simulated water-budget components for (a) steady-state simulation and (b) transient simulation, Edwards aquifer model, San Antonio region, Texas.

because hydraulic heads in the aquifer generally are above river stage and only drop below river stage during periods of low water levels in the aquifer.

The principal discharges from the Edwards aquifer (excluding change in storage) for the transient simulation are springflow and withdrawals by wells (figs. 30, 31; table 15). During 1956, representing drought conditions, the greatest discharge was withdrawals by wells, followed by springflow (figs. 30, 31a). During 1975, representing above-normal rainfall and recharge conditions, the order is reversed, and the greatest discharge was springflow, followed by withdrawals (figs. 30, 31b). During both 1956 and 1975, discharge from the aquifer to the Colorado River is a small component of the budget. Withdrawals by wells was the largest budget component (excluding change in storage) during 1956, with low rainfall resulting in low recharge and increased withdrawals. In contrast, during 1975 the much greater rainfall and corresponding greater recharge (recharge about 17 times greater in 1975 than in 1956) resulted in withdrawals being a proportionately smaller component of the budget (table 15). Springflow was the largest 
(a)

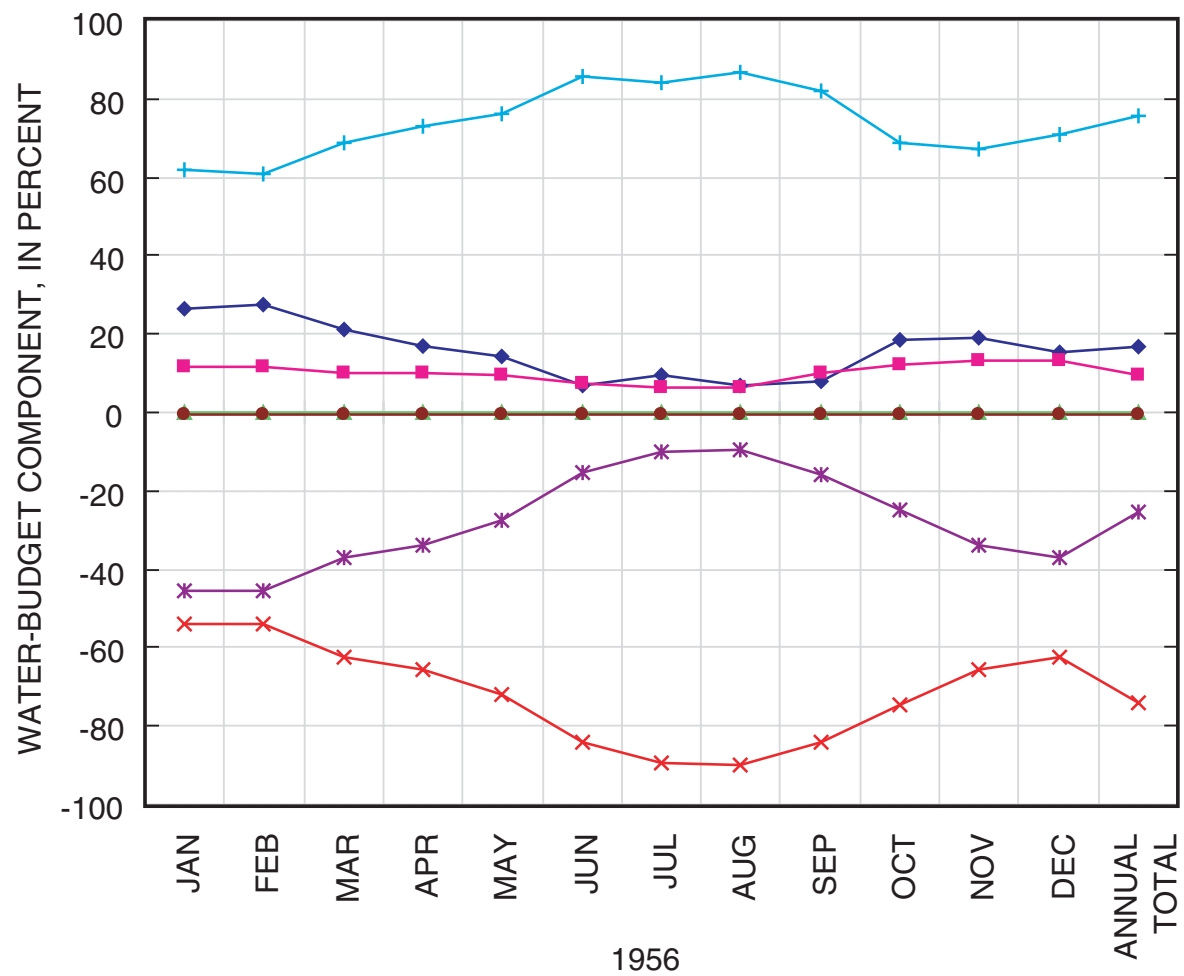

(b)

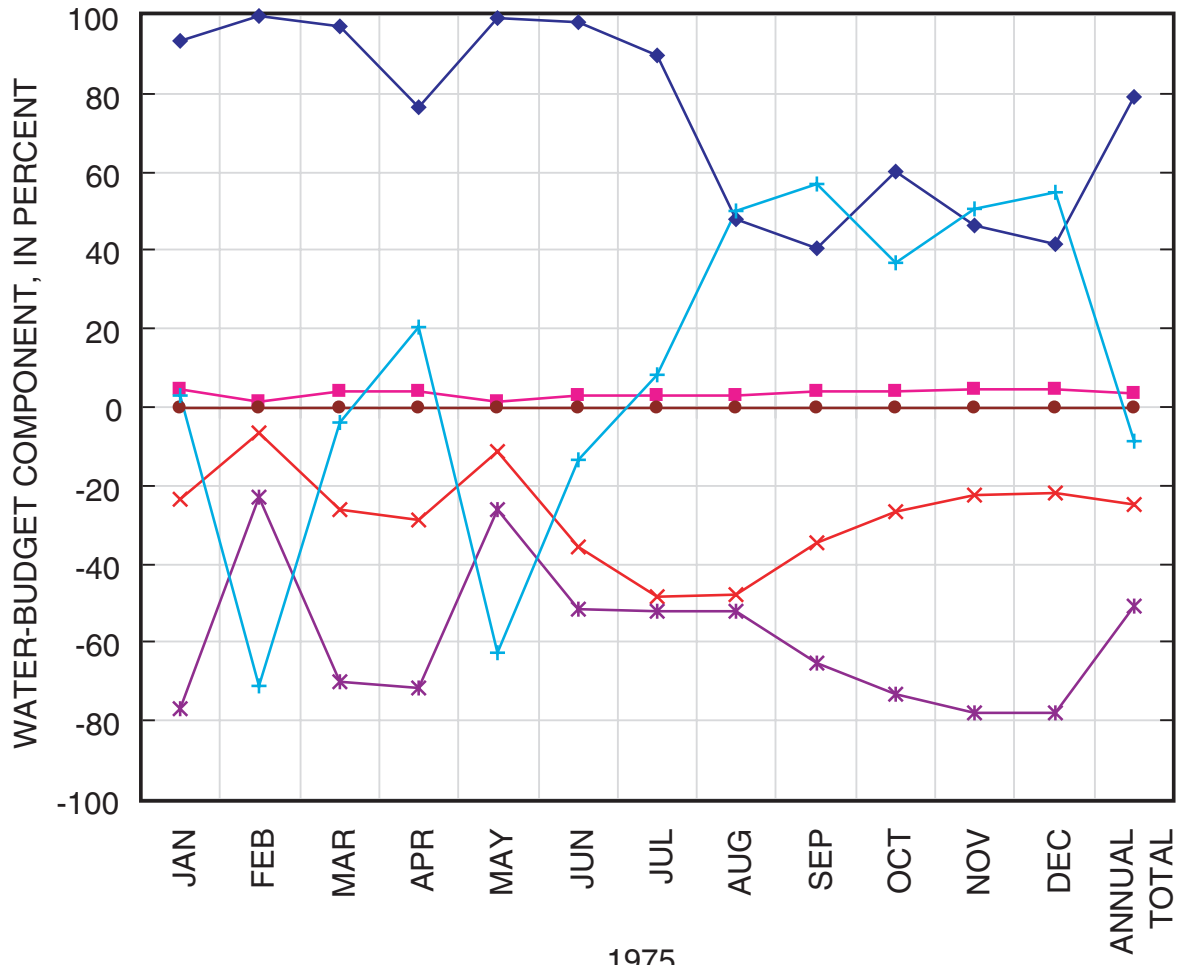

EXPLANATION

Water-budget

component-

drought conditions,

transient simulation

Source

$\multimap$ Recharge

$\rightarrow$ Boundary inflow

_-Stream-aquifer leakage to aquifer

Discharge

$\rightarrow$ Withdrawals

*-Springflow

$\rightarrow$ Stream-aquifer

leakage to stream

\section{Storage}

, Change in storage

Negative change in storage included as a percentage of total sources

\section{EXPLANATION}

Water-budget

component-

and recharge conditions,

transient simulation

\section{Source}

$\longrightarrow$ Recharge

$\rightarrow$ Boundary inflow

Stream-aquifer leakage to aquifer $=0$

\section{Discharge}

$\leftarrow$ Withdrawals

* Springflow

$\longrightarrow$ Stream-aquifer

leakage to stream

Storage

Change in storage

Negative change in storage included as a percentage of total sources

Positive change in storage included as a percentage of total discharges

Figure 31. Simulated water-budget components, as percentages of total sources to and discharges from the Edwards aquifer for (a) drought conditions, 1956, and (b) above-normal rainfall and recharge conditions, 1975, transient simulation, Edwards aquifer model, San Antonio region, Texas. 
discharge from the aquifer during 1975 and much greater than in 1956 (by a factor of about 6) because of higher water levels in the aquifer during 1975 (figs. 15-17; table 15). Water levels in the aquifer depend on both recharge and withdrawal rates. Although withdrawals during 1975 were somewhat greater than during 1956 (17,845.9 acre-ft more), recharge was much greater $(1,002,765.6$ acre-ft more), which resulted in higher water levels. During both 1956 and 1975, the largest springflows tended to occur during the months with large recharge and low withdrawal rates (fig. 31; table 15). However, relatively large springflows might also have occurred during periods of low recharge because of low withdrawal rates and resulting rising water levels.

During 1956, the change in storage (net ${ }^{6}$ water released from storage) was much greater than recharge, accounting for 75.9 percent of the total flow (including change in storage) compared to 14.5 percent for recharge (fig. 31a; table 15). Conversely, during 1975, representing above-normal rainfall and recharge conditions, recharge constituted 79.9 percent of the total flow (including change in storage) compared to 7.1 percent for the change in storage (net ${ }^{7}$ water added to storage) (fig. $31 \mathrm{~b}$, table 15). The amount and percentage of water released from storage is large during 1956 (drought conditions) because recharge is small and more water is required from storage to meet the withdrawal demands. In contrast, during 1975 (abovenormal rainfall and recharge conditions) the amount of recharge exceeded the withdrawal demand and springflow in some months, with a resulting net gain in storage to the aquifer for the year. During 1956, the largest net releases from storage occurred during June-August, the period of largest withdrawals by wells and comparatively low recharge (fig. 31a, table 15). Addition to storage occurred during 1975 because the amount of recharge to the aquifer exceeded withdrawals and springflow from the aquifer, which allowed water to be added to storage. During 1956, no net addition to storage occurred, which indicated the aquifer was being depleted of water during the entire year. During 1975, however, addition to storage occurred during 4 of the 12 months, with a net gain in storage for the year. Net additions to storage occurred in February, March, May, and June, months with comparatively large amounts of recharge (fig. 31b; table 15).

\section{Numerical Model Sensitivity}

There is uncertainty with regard to the capability of any numerical ground-water-flow model to simulate conditions in the real ground-water-flow system. To help assess the uncertainty associated with the Edwards aquifer model, a series of sensitivity tests was made to ascertain how the model results were affected by variations greater than and less than the calibrated values of input data. The degree to which the input data were varied was related to the uncertainty associated with each. Calibrated values were increased or decreased by a parameter multiplier, and variations were kept within reported or plausible ranges of values. The sensitivity of the model results to variations in recharge, withdrawals, hydraulic conductivity, springorifice conductance for Comal and San Marcos Springs, and northern boundary inflow was tested with steady-state and transient simulations. The sensitivity of model results to variations in storativity was tested with transient simulations. Each input parameter was tested independently of the others to isolate the effects of variation in that specific parameter.

Sensitivity analyses were done to evaluate the effects of variations of input parameters on both simulated hydraulic heads and springflows. The change in simulated hydraulic heads was calculated for the calibration target wells for steadystate (stress period 1), drought (August 1956, stress period 117), and above-normal rainfall and recharge (February 1975, stress period 339) conditions. The change in simulated hydraulic heads was quantified by computing the mean difference between the simulated hydraulic heads for the calibrated simulation and the sensitivity simulation for each of the three sets of calibration target wells. The change in simulated springflows was quantified by computing the mean difference between the simulated springflows for the calibrated simulation and the sensitivity simulation for the five springs used for model calibration.

In addition, hydrographs for the Bexar County index well (J-17, TWDB 6837203), the Uvalde County index (well J-27, TWDB 6950302), Comal Springs, and Leona Springs were used to evaluate the effects of variations of input parameters on both simulated hydraulic heads and springflows over time. Further sensitivity simulations were made to evaluate the effects of the location of the southern no-flow model boundary and of raising the spring-orifice altitude for Comal and San Marcos Springs on simulated hydraulic heads and springflows.

\section{Hydraulic Heads}

The results of the sensitivity analyses for hydraulic heads are shown in figure 32. Positive values indicate that simulated hydraulic heads for the sensitivity simulation are larger than calibrated values, and negative values indicate that simulated hydraulic heads for the sensitivity simulation are smaller than the calibrated values. Simulated hydraulic heads in the Edwards aquifer model were most sensitive to recharge, withdrawals, hydraulic conductivity of the conduit segments, and specific yield and relatively insensitive to spring-orifice conductance for Comal and San Marcos Springs, northern boundary inflow, and specific storage (fig. 32). Larger values of recharge and northern boundary inflow resulted in higher simulated hydraulic heads. Larger values of withdrawals, hydraulic conductivity,

\footnotetext{
${ }^{6}$ Net equals total for 1956 , on the basis of summing monthly changes in storage, because there was a net loss from storage in each month of 1956.

${ }^{7}$ Net does not equal total for 1975 , on the basis of summing monthly changes in storage, because there was a net gain to storage in 4 months of 1975 and a net loss from storage in 8 months of 1975 .
} 
(a)

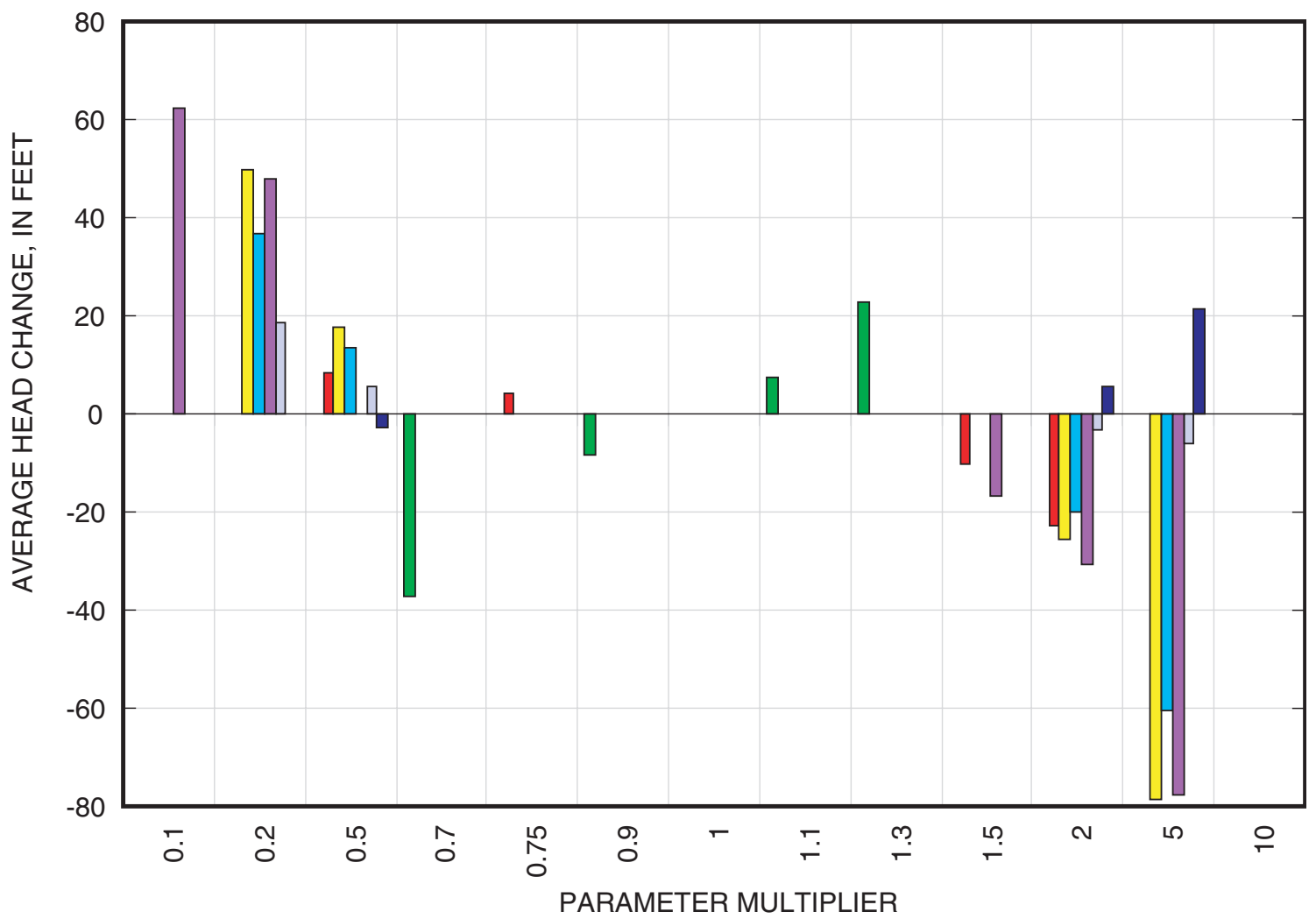

EXPLANATION

Sensitivity of simulated
hydraulic heads-steady-state
simulation
$\square$ Recharge
$\square$ Withdrawals
$\square \quad \begin{aligned} & \text { Hydraulic conductivity of the } \\ & \text { background distribution, recharge } \\ & \text { and confined zones }\end{aligned}$

Hydraulic conductivity of the background distribution, confined zone only

$\square$ Hydraulic conductivity of conduit segments

$\square \quad$ Spring-orifice (drain) conductance for Comal and San Marcos Springs

- Northern boundary inflow

Figure 32a. Sensitivity of simulated hydraulic heads to changes in model parameters at calibration wells for steady-state simulation, Edwards aquifer model, San Antonio region, Texas.

and spring-orifice conductance for Comal and San Marcos Springs resulted in lower simulated hydraulic heads. Larger values of specific yield and specific storage resulted in higher simulated hydraulic heads during drought conditions (fig. 32b) and lower simulated hydraulic heads during above-normal rainfall and recharge conditions (fig. 32c). Conversely, smaller values of specific yield and specific storage resulted in lower simulated hydraulic heads during drought conditions and higher simulated hydraulic heads during above-normal rainfall and recharge conditions. The sensitivity to withdrawals and hydraulic conductivity was somewhat asymmetric in that increases in these parameters resulted in greater differences between calibratedsimulation and sensitivity-simulation hydraulic heads than did decreases.
For hydraulic conductivity, variations in three components of the distribution were investigated. The three components are (1) the hydraulic conductivity of the background distribution (distribution of Painter and others [2002]) in both the recharge and confined zones of the aquifer (with no change in the hydraulic conductivity of the conduit segments), (2) the hydraulic conductivity of the background distribution in the confined zone of the aquifer only (with no change in the background hydraulic conductivity in the recharge zone or in the hydraulic conductivity of the conduit segments), and (3) the hydraulic conductivity of the conduit segments (with no change in the background hydraulic conductivity). Variations in the hydraulic conductivities of the background distribution in both the recharge and confined zones of the aquifer or in the conduit segments resulted in greater differences between calibrated and 
(b)

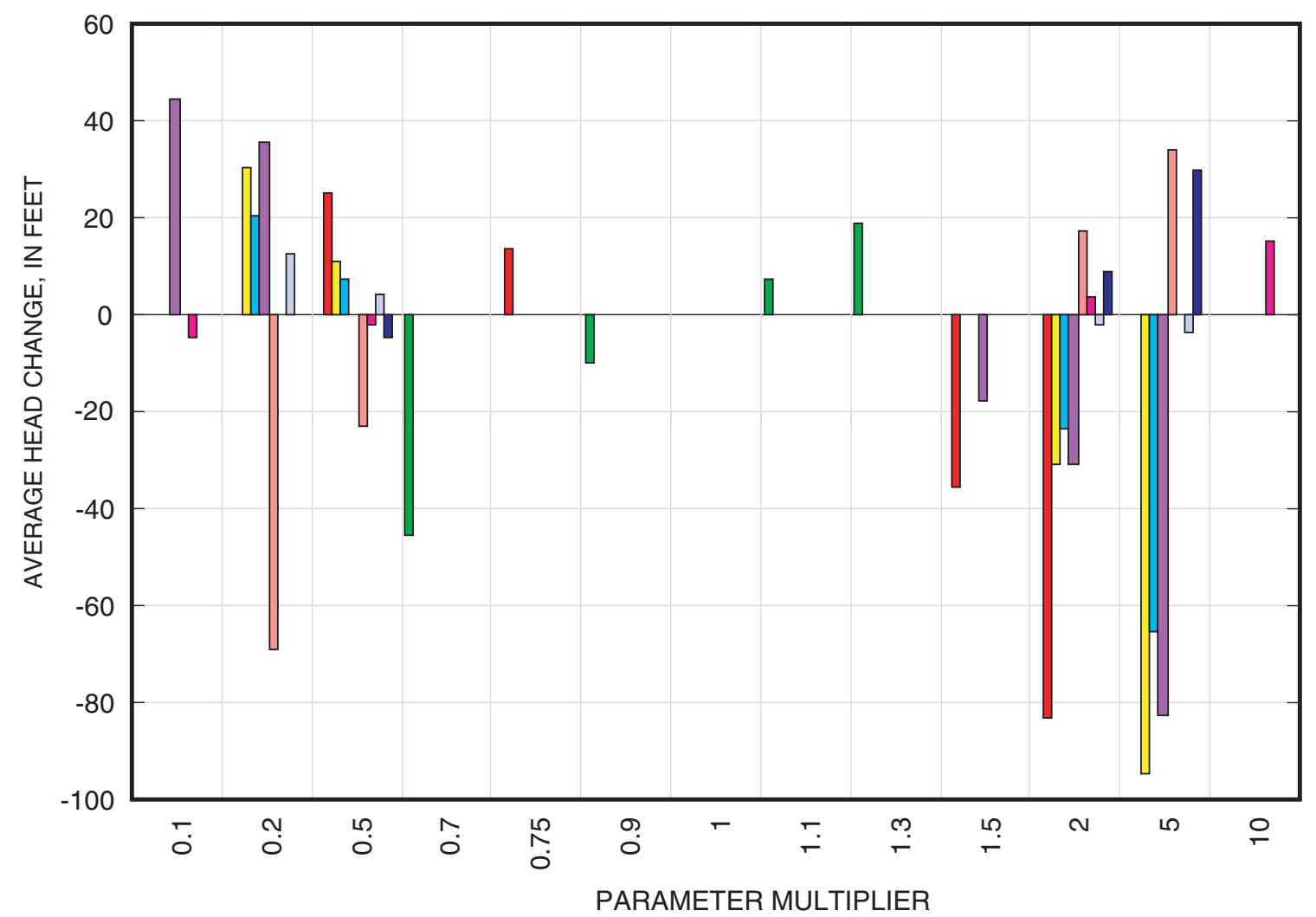

\section{EXPLANATION}

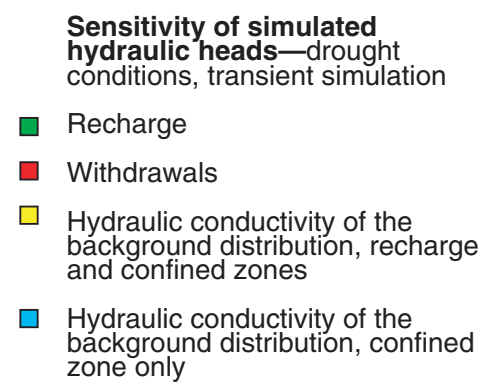

Hydraulic conductivity of conduit segments

$\square$ Specific yield

- Specific storage

$\square \quad$ Spring-orifice (drain) conductance for Comal and San Marcos Springs

Northern boundary inflow

Figure 32b. Sensitivity of simulated hydraulic heads to changes in model parameters at calibration wells for drought conditions, August 1956 (stress period 117), transient simulation, Edwards aquifer model, San Antonio region, Texas.

sensitivity simulation hydraulic heads than did varying the hydraulic conductivities of the background distribution in the confined zone of the aquifer only. The effect of increasing the hydraulic conductivities of the background distribution in both the recharge and confined zones of the aquifer, however, was amplified because increases in hydraulic conductivity for the recharge zone resulted in extensive areas of model cells going dry, and thereby reduced simulated recharge. The result of reduced simulated recharge was to increase the differences in hydraulic heads between the calibrated simulation and the sensitivity simulation, compared to what the differences would have been if model cells had not gone dry for the sensitivity simulations. The same effect occurred when the hydraulic conductivity of the conduit segments was increased-increasing the hydraulic conductivity of conduit segments originating in the recharge zone caused more water to flow out of the recharge zone, which resulted in declines in hydraulic heads and model cells going dry. Because model cells went dry, the sensitivity simulations with increases in hydraulic conductivity indicate the sensitivity of hydraulic heads to both the increases in hydraulic conductivity and reduced recharge, not just increases in hydraulic conductivity.

The effects of the location of the southern no-flow model boundary and of raising the spring-orifice altitudes of Comal 
(c)

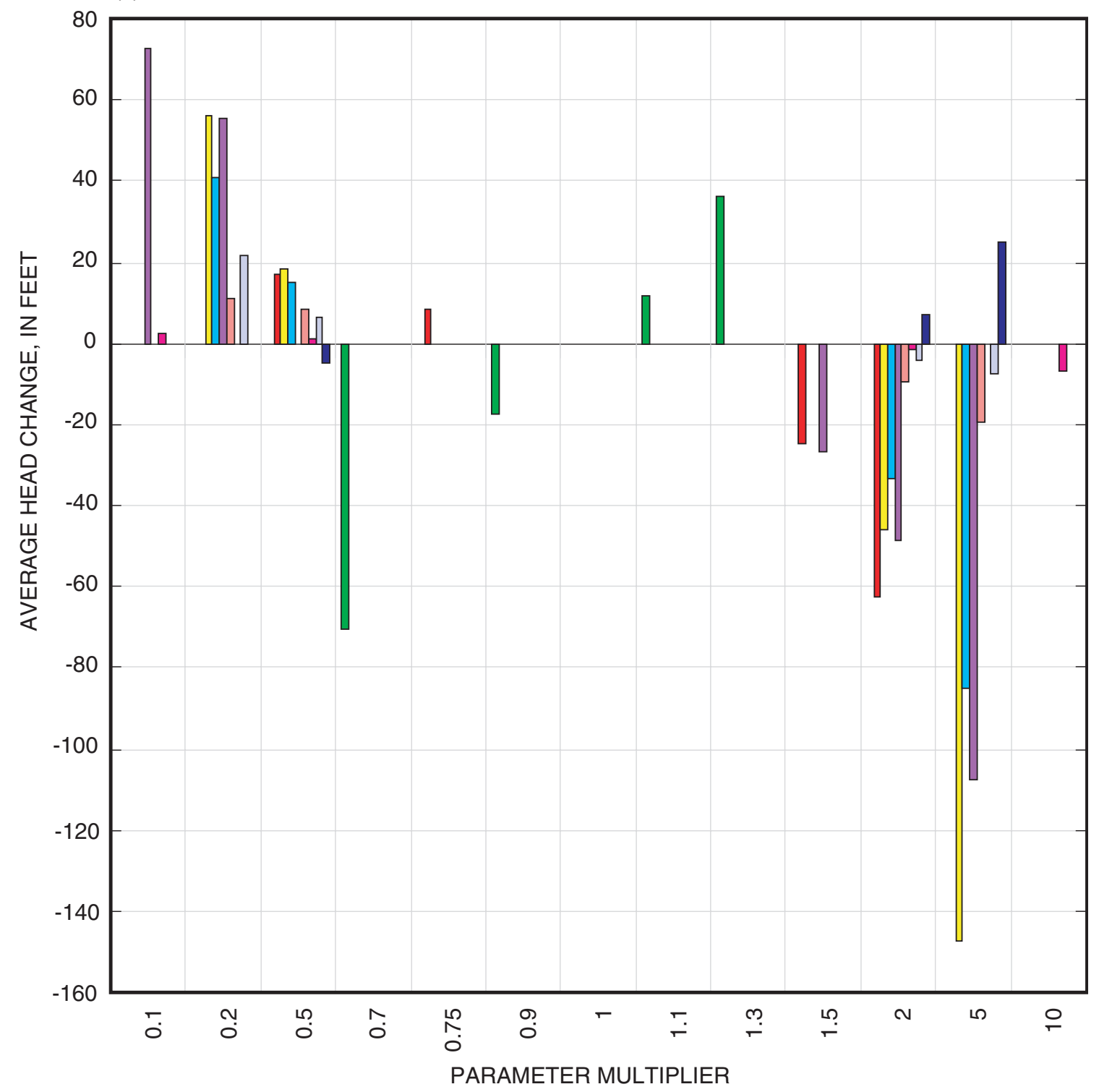

\section{EXPLANATION}

Sensitivity of simulated
hydraulic heads-above-
normal rainfall and recharge
conditions, transient simulation
Recharge
Withdrawals
Hydraulic conductivity of the
background distribution, recharge
and confined zones
Hydraulic conductivity of the
background distribution, confined
zone only

$\square$ Hydraulic conductivity of conduit segments

$\square$ Specific yield

$\square$ Specific storage

$\square$ Spring-orifice (drain) conductance for Comal and San Marcos Springs

- Northern boundary inflow

$\square$ Hydraulic conductivity of the zone only

Figure 32c. Sensitivity of simulated hydraulic heads to changes in model parameters at calibration wells for above-normal rainfall and recharge conditions, February 1975 (stress period 339), transient simulation, Edwards aquifer model, San Antonio region, Texas. 
and San Marcos Springs on simulated hydraulic heads are shown in figure 33. Moving the simulated southern no-flow model boundary northward from the 10,000-mg/L dissolved solids concentration line to the $1,000-\mathrm{mg} / \mathrm{L}$ dissolved solids concentration line resulted in lower water levels in the Bexar County index well and higher water levels in the Uvalde County index well compared to the calibrated levels represented by the calibrated spring-orifice altitude in figure 33. This was because the extent of the model area was reduced, which apparently resulted in less ground-water flow from west to east. The effect of lowering the simulated spring-orifice altitudes of Comal and San Marcos Springs from calibrated levels to their initial levels (table 11) was to appreciably lower hydraulic heads in the aquifer (fig. 33). Comal and San Marcos Springs are regional sinks for the San Antonio segment of the Edwards aquifer, and the spring-orifice altitudes serve as a controlling base level for hydraulic heads in the aquifer. Assuming that the hydraulic gradients in the aquifer remain the same, there is a direct relation between the altitudes of the spring orifices and the level of hydraulic heads in the aquifer. Raising the altitudes of the spring orifices results in corresponding higher water levels in the entire aquifer, and decreasing the altitudes of the spring orifices results in corresponding lower water levels in the entire aquifer.

\section{Springflow}

Springflow is directly related to hydraulic heads in the aquifer and so is generally sensitive to the same parameters as hydraulic heads, as described in the preceding section. A difference is that springflow is more sensitive to increases in the northern boundary inflow than are hydraulic heads (fig. 34). For drought conditions (fig. 34b), the calibrated springflow for the springs other than San Marcos Springs was zero, which resulted in a maximum possible difference between calibrated and sensitivity simulation springflow of $954,700 \mathrm{ft}^{3} / \mathrm{d}\left(11 \mathrm{ft}^{3} / \mathrm{s}\right)$ (the calibrated springflow for San Marcos Springs). Larger values of recharge and northern boundary inflow resulted in larger simulated springflows. Larger withdrawals resulted in smaller simulated springflows. Larger values of hydraulic conductivity, coupled with reduced recharge, resulted in smaller simulated springflows. If the reduced recharge is accounted for, however, larger values of hydraulic conductivity result in increased springflows.

As with hydraulic heads, the effect of increasing the hydraulic conductivities of the background distribution in both the recharge and confined zones of the aquifer was influenced by extensive areas of model cells going dry in the recharge zone, and thereby reduced simulated recharge. Because model cells went dry, the sensitivity simulations with increases in hydraulic conductivity indicate the sensitivity of springflow to both the increases in hydraulic conductivity and reduced recharge, not just the increases in hydraulic conductivity. However, it is possible to compensate for the effects of the reduced recharge in the sensitivity simulations with increases in hydrau- lic conductivity, at least for steady-state conditions, by assuming that the amount of the reduction in recharge represents water that would have discharged to the springs had the model cells not gone dry. Therefore, the difference in recharge between the calibrated simulation and the sensitivity simulation was added to the difference in springflow between the calibrated and sensitivity simulations. The result is an increase in simulated springflows because of increases in hydraulic conductivity (fig. 35), rather than the decrease because of the combination of increased hydraulic conductivity and reduced recharge (fig. 34). Assuming that the same assumption can be made for the transient sensitivity simulations as for the steady-state sensitivity simulations - that the amount of the reduction in recharge represents water that would have discharged to the springs had the model cells not gone dry-corresponding springflow increases under drought conditions and above-normal recharge conditions can be computed. Increasing the hydraulic conductivities of the background distribution in both the recharge and confined zones of the aquifer, and accounting for the reduced recharge because cells went dry, resulted in increases of about 324,600 and 120,550,000 $\mathrm{ft}^{3} / \mathrm{d}$ for drought conditions and above-normal recharge conditions, respectively.

Larger values of specific yield and specific storage resulted in larger simulated springflow during drought conditions (fig. 34b) and smaller simulated springflow during abovenormal rainfall and recharge conditions (fig. 34c). Conversely, smaller values of specific yield and specific storage resulted in smaller simulated springflow during drought conditions and larger simulated springflows during above-normal rainfall and recharge conditions. As with hydraulic heads, the sensitivity of springflow to withdrawals and hydraulic conductivity was asymmetric. The sensitivity to hydraulic conductivity was strongly asymmetric in that increases in this parameter resulted in much greater differences between calibrated-simulation and sensitivity-simulation springflow than did decreases (figs. 34, $35)$. In addition, the sensitivity to variations in the northern boundary inflow was asymmetric, with increases in the northern boundary inflow resulting in greater differences between calibrated-simulation and sensitivity-simulation springflow than decreases (fig. 34).

The effects of the location of the southern no-flow model boundary and of raising the spring-orifice altitudes for Comal and San Marcos Springs on simulated springflows for Comal and Leona Springs are shown in figure 36. Moving the simulated southern no-flow model boundary northward from the $10,000-\mathrm{mg} / \mathrm{L}$ dissolved solids concentration line to the $1,000-$ $\mathrm{mg} / \mathrm{L}$ dissolved solids concentration line resulted in reduced springflow for Comal Springs and increased springflow for Leona Springs compared to calibrated flows represented by the calibrated spring-orifice altitude in figure 36, similar to the effects on water levels in the Bexar and Uvalde County index wells. The effect of lowering the simulated spring-orifice altitudes for Comal and San Marcos Springs from calibrated levels to initial levels was to minimally increase springflow for Comal Springs and appreciably decrease springflow for 
(a)

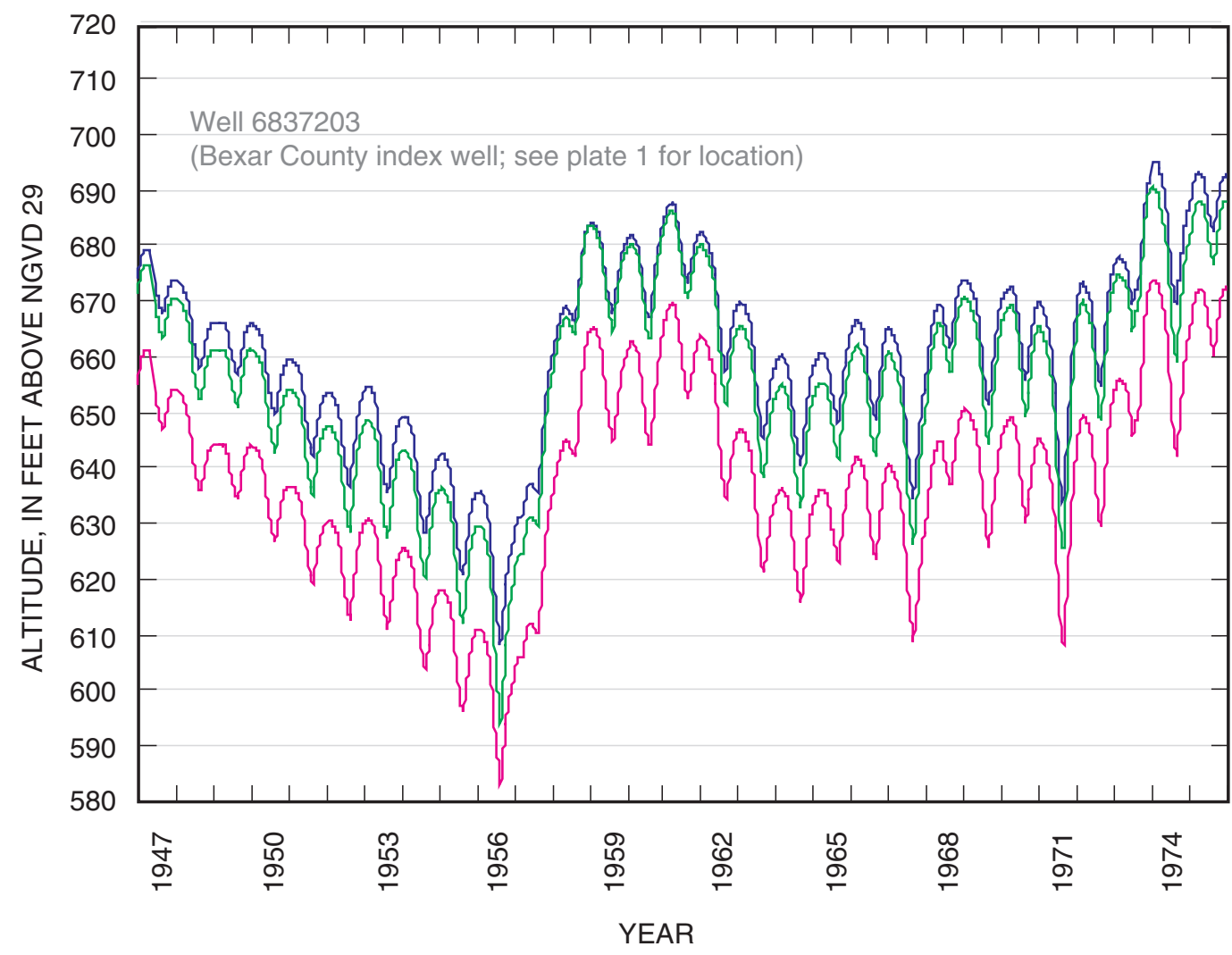

EXPLANATION

Sensitivity of simulated hydraulic heads

- Southern model boundary of active area at line of 1,000 milligrams per liter dissolved solids concentration

- Calibrated springorifice altitude (drain elevation) for Comal and San Marcos Springs (See table 11)

_ Initial spring-orifice altitude (drain elevation) for Comal and San Marcos Springs (See table 11)

(b)

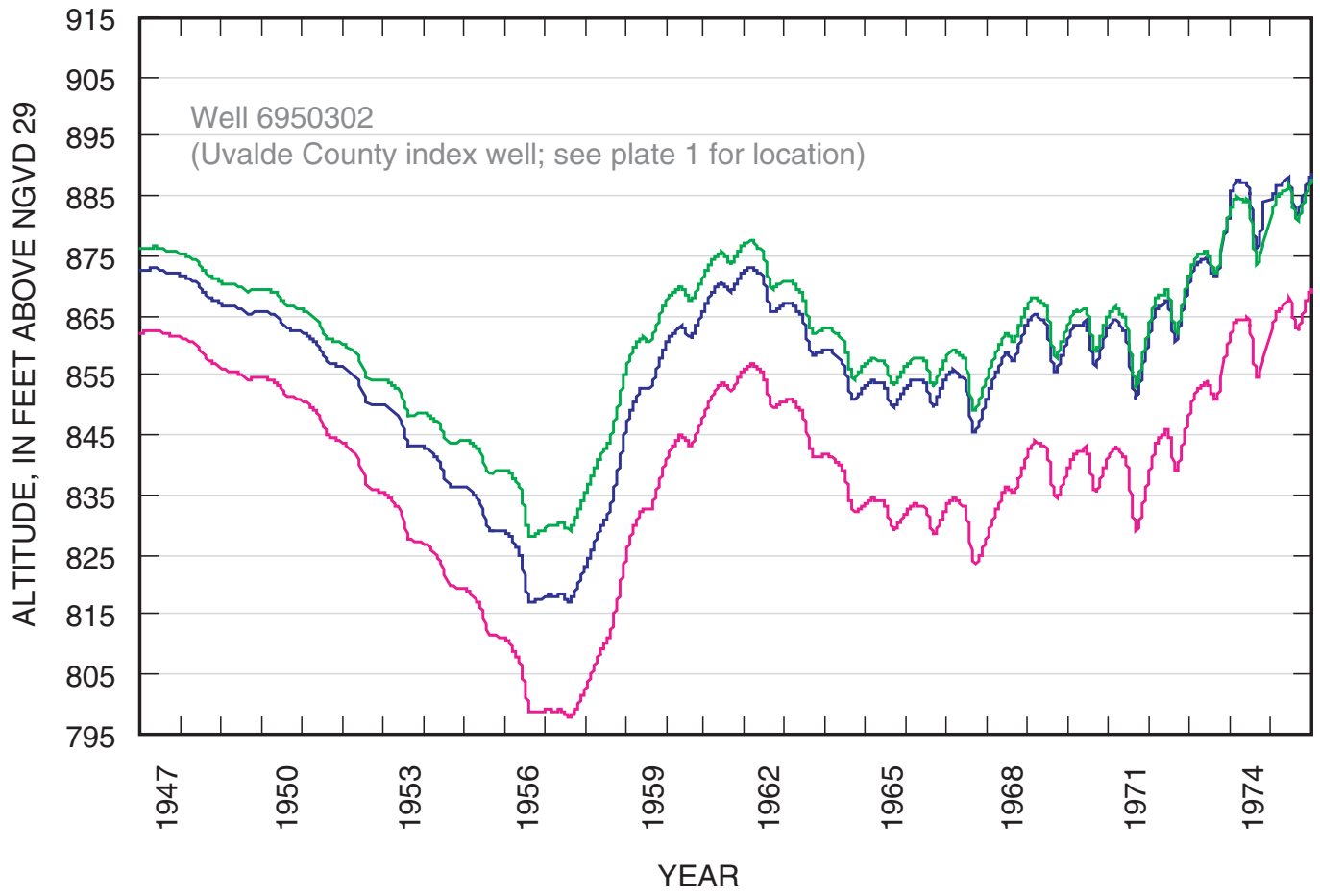

EXPLANATION

Sensitivity of simulated hydraulic heads

Southern model boundary of active area at line of 1,000 milligrams per liter dissolved solids concentration

- Calibrated springorifice altitude (drain elevation) for Comal and San Marcos Springs (See table 11)

- Initial spring-orifice altitude (drain elevation) for Comal and San Marcos Springs (See table 11)

Figure 33. Sensitivity of simulated hydraulic heads in (a) Bexar County index well $(\mathrm{J}-17,6837203)$ and (b) Uvalde County index well $(\mathrm{J}-27,6950302)$ to changes in location of the southern model boundary and spring-orifice altitude, Edwards aquifer model, San Antonio region, Texas. 
(a)

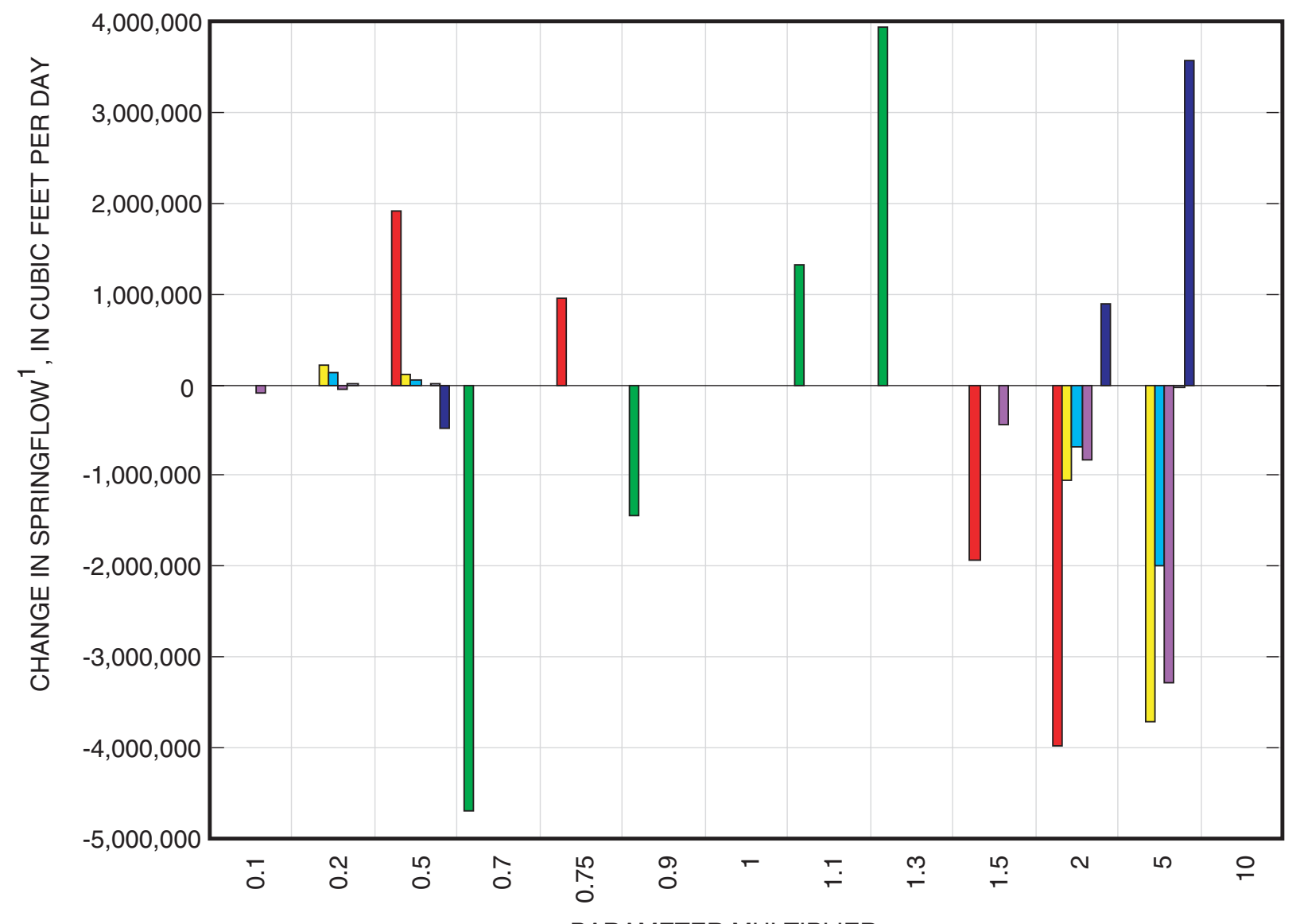

PARAMETER MULTIPLIER

\section{EXPLANATION}

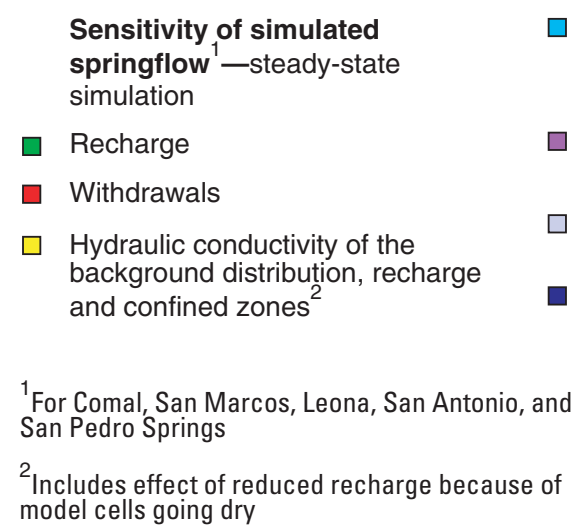

Hydraulic conductivity of the background distribution, confined zone only ${ }^{2}$

Hydraulic conductivity of conduit segments ${ }^{2}$

$\square$ Spring-orifice (drain) conductance for Comal and San Marcos Springs

Northern boundary inflow

Figure 34a. Sensitivity of simulated springflow to changes in model parameters at simulated springs for steady-state simulation, Edwards aquifer model, San Antonio region, Texas.

Leona Springs (fig. 36). Variations in the altitudes of the spring orifices have minimal effects on springflows at Comal Springs (fig. 36a), but appreciable effects on hydraulic heads (fig. 33). The appreciable reduction in springflow that occurred for Leona Springs (fig. 36b) was because of the lowering of hydraulic heads in the aquifer (fig. 33). Variations in the orifice altitudes of Comal and San Marcos Springs result in minimal change in the duration of the period of zero springflow at Comal Springs during drought conditions (fig. 36a) because Comal Springs is a regional sink in the downgradient part of the 
(b)

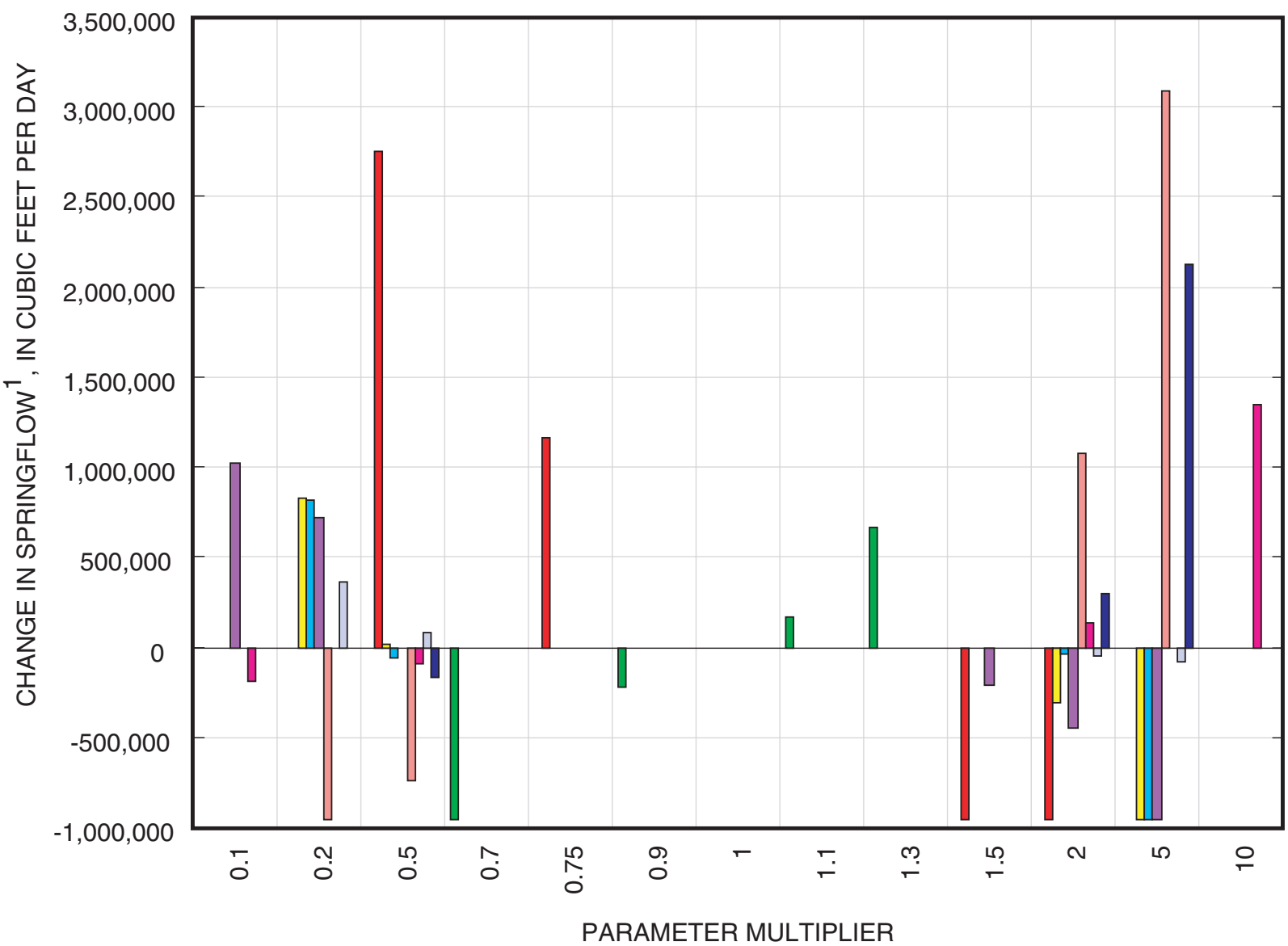

\section{EXPLANATION}

\section{Sensitivity of simulated}

springflow - drought conditions transient simulation

$\square$ Recharge

Withdrawals

$\square$ Hydraulic conductivity of the background distribution, recharge and confined zones

Hydraulic conductivity of the background distribution, confined zone only ${ }^{2}$

${ }^{1}$ For San Marcos Springs (springflow for Comal, Leona, San Antonio, and San Pedro Springs for the calíbrated transient simulation for drought conditions [stress period 117] is zero)

${ }^{2}$ Includes effect of reduced recharge because of model cells going dry

Figure 34b. Sensitivity of simulated springflow to changes in model parameters at simulated springs for drought conditions, August 1956 (stress period 117), transient simulation, Edwards aquifer model, San Antonio region, Texas.

ground-water-flow system. In contrast, variations in the orifice altitudes of Comal and San Marcos Springs result in appreciable changes in the duration of periods of zero springflow at Leona Springs in the western, upgradient part of the aquifer. Lowering the altitudes of the spring orifices results in appreciable increases in the duration of periods of zero springflow for Leona Springs (fig. 36b) because of the lower water levels in the aquifer (fig. 33b). 
(c)

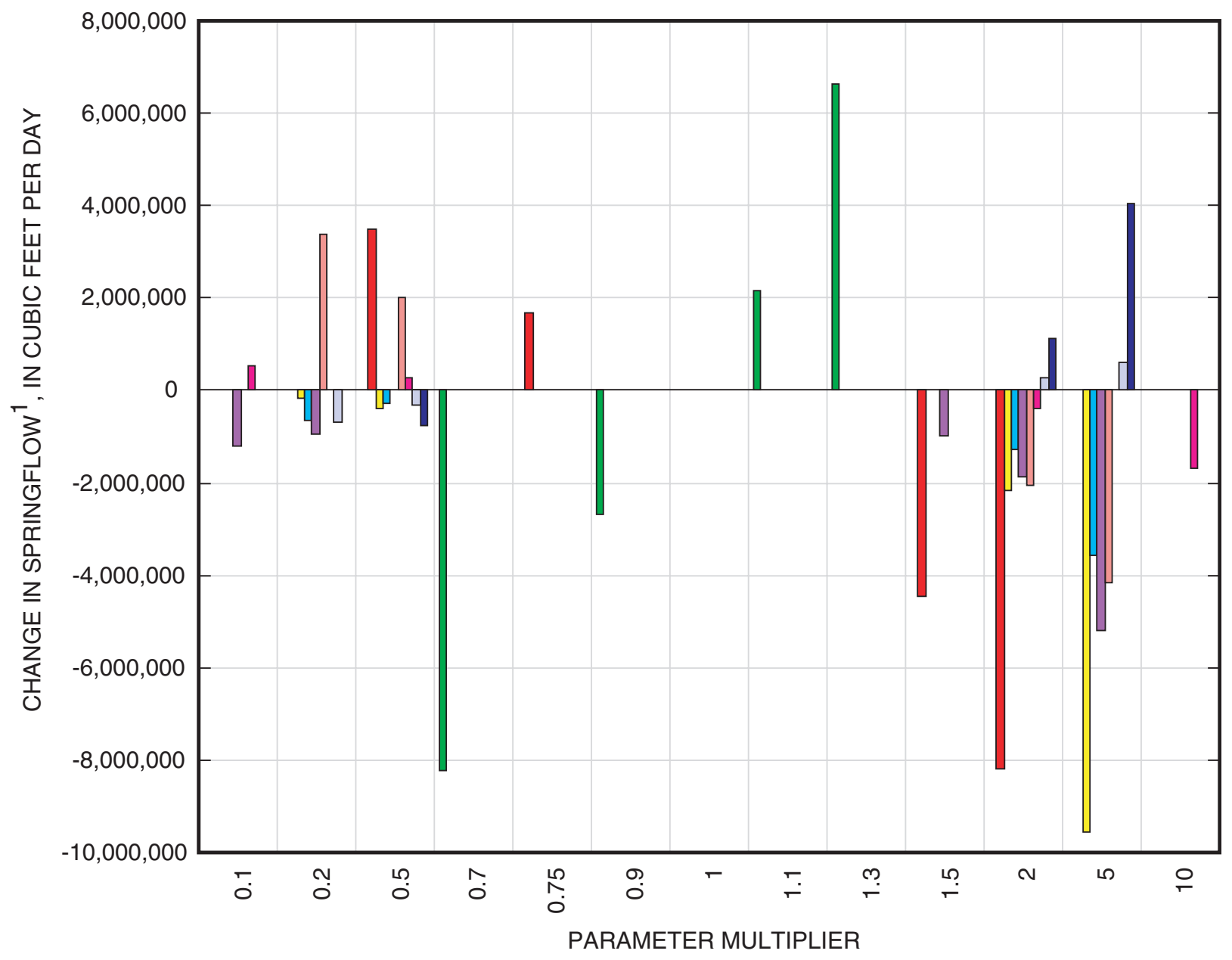

EXPLANATION

Sensitivity of simulated

springflow ${ }^{1}$-above-normal rainfall and recharge conditions, transient simulation

$\square$ Recharge

$\square$ Withdrawals

$\square$ Hydraulic conductivity of the background distribution, recharge and confined zones

$\square$ Hydraulic conductivity of the background distribution, confined zone only ${ }^{2}$

${ }^{1}$ For Comal, San Marcos, Leona, San Antonio, and San Pedro Springs

${ }^{2}$ Includes effect of reduced recharge because of model cells going dry

Figure 34c. Sensitivity of simulated springflow to changes in model parameters at simulated springs for above-normal rainfall and recharge conditions, February 1975 (stress period 339), transient simulation, Edwards aquifer model, San Antonio region, Texas. 


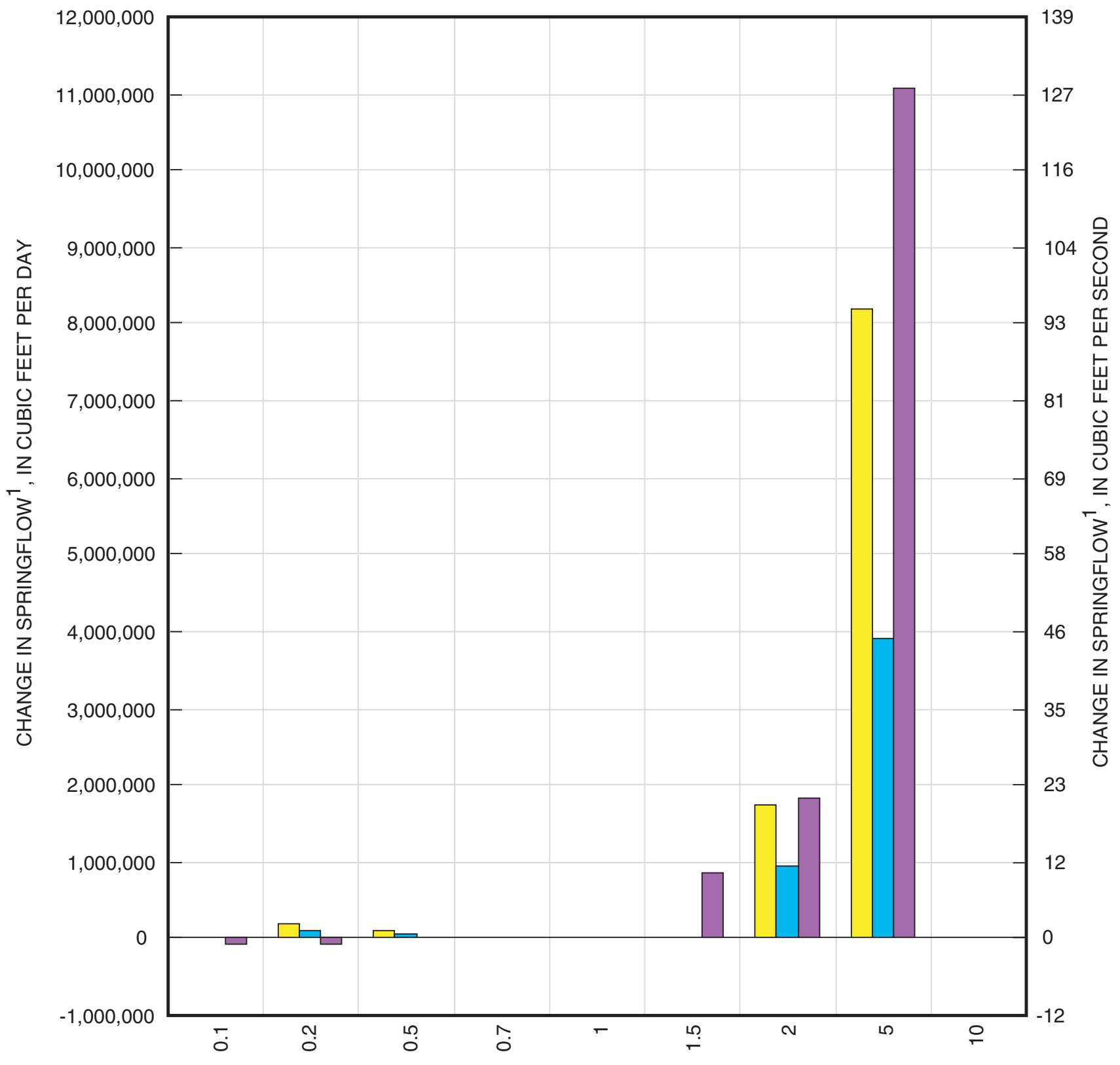

HYDRAULIC CONDUCTIVITY MULTIPLIER

\section{EXPLANATION}

Sensitivity of simulated

springflow —steady-state simulation

Hydraulic conductivity of the

background distribution, recharge

and confined zones ${ }^{2}$

${ }^{1}$ For Comal, San Marcos, Leona, San Antonio, and San Pedro Springs

${ }^{2}$ Assumption made that the amount of the reduction in recharge because of model cells going dry represents water that would have discharged to the springs had the model cells not gone dry
Hydraulic conductivity of the background distribution, confined zone only ${ }^{2}$

Hydraulic conductivity of conduit segments $^{2}$

Figure 35. Sensitivity of simulated springflow to changes in hydraulic conductivity at simulated springs for steady-state simulation, Edwards aquifer model, San Antonio region, Texas 
(a)

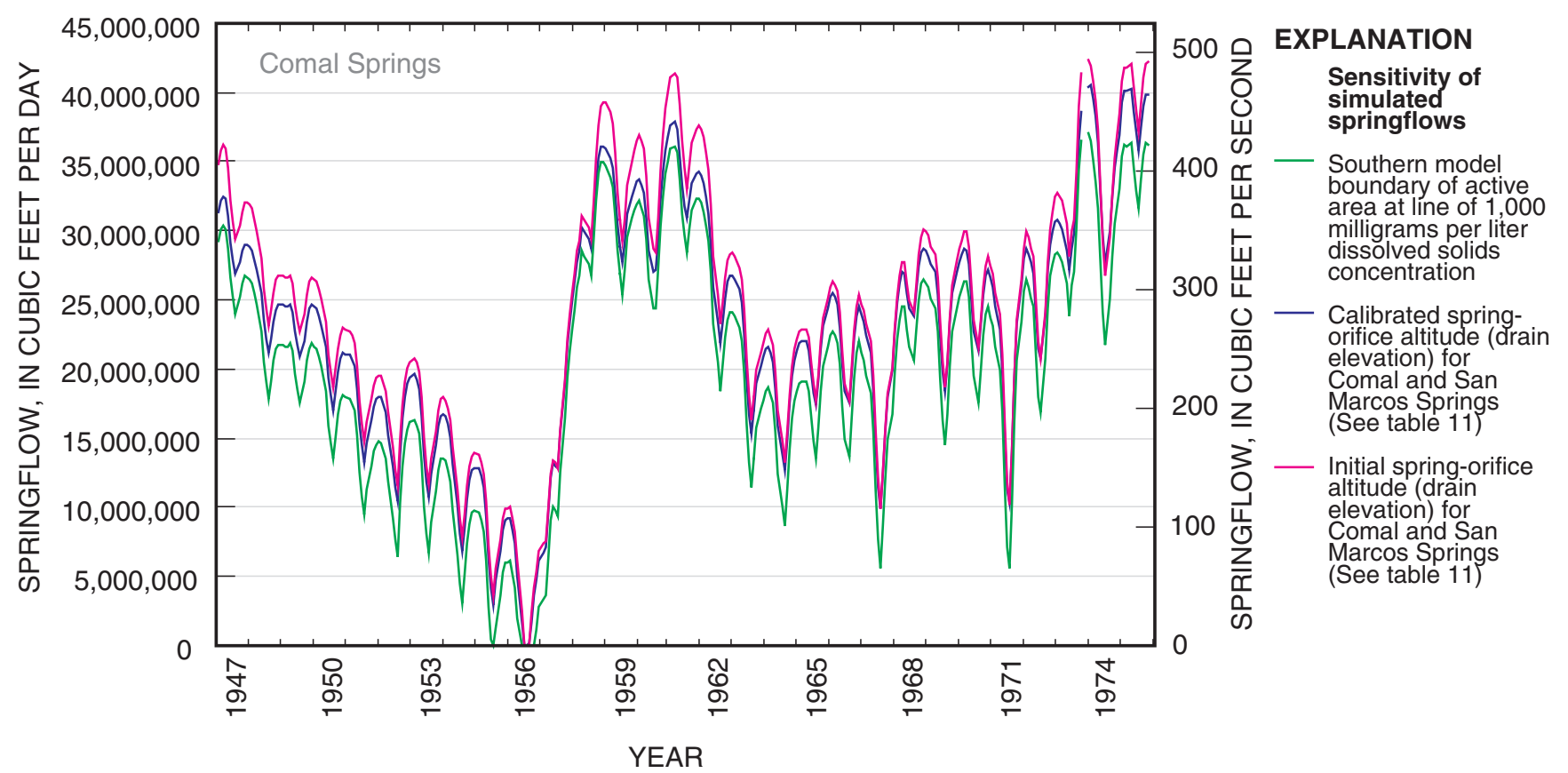

(b)

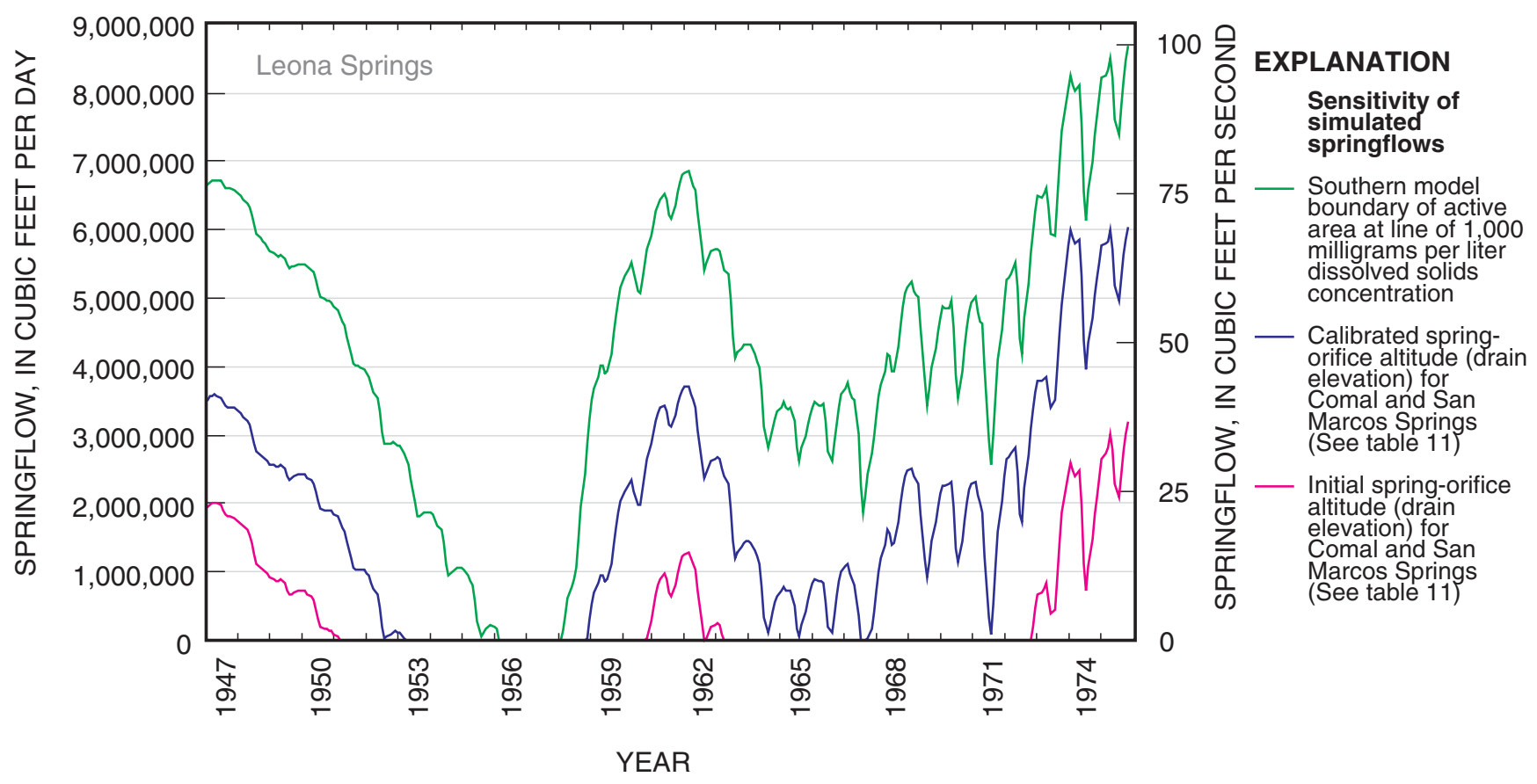

Figure 36. Sensitivity of simulated springflow from (a) Comal and (b) Leona Springs to changes in location of the southern model boundary and spring-orifice altitude, Edwards aquifer model, San Antonio region, Texas.

\section{Comparison With GWSIM Model}

Hydraulic heads and springflows simulated by the Edwards aquifer model for selected observation wells and springs were compared to the corresponding hydraulic heads and springflows simulated by the GWSIM model. The time periods used for the comparisons were 1947-59 and 197889 because published simulated hydraulic heads and springflows from GWSIM were available for these time periods (Thorkildsen and McElhaney, 1992). Comparisons of simulated 
hydraulic heads and springflows were made for both the 194759 and 1978-89 periods using the Bexar County index well (J-17, TWDB 6837203) and Comal and San Marcos Springs. Also, hydraulic heads simulated by the Edwards aquifer model for 26 observation wells, in addition to the Bexar County index well, were compared to the corresponding hydraulic heads simulated by GWSIM for the 1978-89 time period. Hydraulic heads simulated by GWSIM for this time period are shown in LBG-Guyton Associates (1996). One well (Frio River well 6935501) shown in LBG-Guyton Associates (1996) was not used in the comparison between the Edwards aquifer model and GWSIM because accurate location information is not available. The results of the comparison between the simulated hydraulic heads and springflows for the Edwards aquifer model and GWSIM are shown in hydrographs for selected observation wells and springs (figs. 37-40) and summarized in table 16 (at end of report). The mean absolute difference and RMS error of the residuals and the RMS error divided by the range in measured hydraulic head or measured springflows (RMS error/range) for the Edwards aquifer model and GWSIM are tabulated. These statistical parameters are used as quantitative measures of the goodness of fit between the simulated and measured hydraulic heads and springflows.

The mean absolute difference, the RMS error of the residuals, and the RMS error/range for the Edwards aquifer model are appreciably smaller than those for GWSIM for both time periods for the Bexar County index well (J-17, TWDB 6837203) and for San Marcos Springs, and for the 1947-59 time period for Comal Springs (table 16). The RMS errors for the Bexar County index well for GWSIM are about 42 and 28 percent greater than for the Edwards aquifer model for the 1947-59 and 1978-89 time periods, respectively. For San Marcos Springs, the RMS errors for GWSIM are about 89 and 78 percent greater for the 1947-59 and 1978-89 time periods, respectively. Conversely, the statistical measures for the Edwards aquifer model generally are larger than those for GWSIM for the observation wells in and near the recharge zone (unconfined conditions). The statistical measures for the Edwards aquifer model and GWSIM generally are similar for observation wells in the confined zone of the aquifer. The mean absolute difference and RMS error of the residuals and the RMS error/range for the Edwards aquifer model are smaller than for GWSIM for the Uvalde County index well (J-27, 6950302) in the confined zone of the aquifer in Uvalde County and for two of the four observation wells in the confined zone of the aquifer in Medina County. Hydrographs also illustrate the smaller differences between simulated and measured hydraulic heads and springflows for the Edwards aquifer model compared to those from GWSIM for the Bexar County index well (J-17, TWBD 6837203) and the Uvalde County index well (J-27, TWDB 6950302) for the 1978-89 time period (fig. 37), for Comal Springs for the 1947-59 time period (fig. 38a), and for San Marcos Springs during both time periods (fig. 39).

The residual statistics (mean absolute difference and RMS error of the residuals) in some cases are not a complete measure of the goodness of fit between the simulated and measured hydraulic heads. In the case of three wells, the hydrographs indicate that the Edwards aquifer model more accurately simulates the magnitude and pattern of fluctuations in measured water levels than does GWSIM (fig. 40), although the residual statistics are smaller for GWSIM than for the Edwards aquifer model (table 16). The three wells are wells 5857902 and 5858101 in the confined zone of the aquifer in Hays County and well 6937402 in the unconfined part of the aquifer in Uvalde County.

The goodness of fit between simulated and measured hydraulic heads and springflows also is influenced by the time period of the comparison. Eight of the 27 wells used in the comparison between the Edwards aquifer model and GWSIM were used as calibration targets in the Edwards aquifer model for longer time periods (for most wells, 1947-2000) than the 1947-59 and 1978-89 periods (table 16). For four of the eight wells, the residual statistics for the Edwards aquifer model were smaller (indicating a closer match between simulated and measured hydraulic heads) for the longer time period than those for the shorter time period (table 16). For three of the eight wells, the residual statistics for the Edwards aquifer model for the longer time period were smaller than the residual statistics for the 1978-89 time period for GWSIM. The RMS error/range values are smaller for the longer time periods because the decreases or comparatively small increases in the RMS errors are coupled with greater ranges in measured hydraulic heads. The residual statistics for the Bexar County index well ( $\mathrm{J}-17$, TWDB 6837203) and for Comal and San Marcos Springs for the longer time period are about equal to the average of those for the 1947-59 and 1978-89 time periods. The residual statistics indicate that, in some cases, the goodness of fit for any given time period does not accurately reflect the goodness of fit for a longer time period for which measured hydraulic heads might be available. This illustrates the value and importance of relatively long transient calibration periods that encompass a range of hydrologic conditions and the potential for erroneous conclusions regarding goodness of fit based on comparatively short periods of comparison between simulated and measured hydraulic heads. For wells 6816801 and 6823701 in Comal County, the mean absolute differences between simulated and measured heads for the Edwards aquifer model are much smaller for the longer time periods ( 3.4 and $6.7 \mathrm{ft}$, respectively) than for the 1978-89 time period (13.3 and $38.1 \mathrm{ft}$, respectively) (table 16). This indicates that the goodness of fit for time periods other than 1978-89, and the overall goodness of fit, is appreciably better than the goodness of fit reflected in the 197889 residual statistics.

The goodness of fit between simulated and measured springflows, as indicated by the statistical measures in table 16 and the hydrograph comparisons shown in figures 38 and 39 , is appreciably better for the Edwards aquifer model compared to GWSIM. However, the statistical measures for the Edwards aquifer model for most of the observation wells in and near the recharge zone (unconfined conditions) are high, indicating a poor match between simulated and measured hydraulic heads. Comparatively small simulated specific yields in the Edwards aquifer model (generally 0.005 to 0.05 ) result in appreciably 
(a)
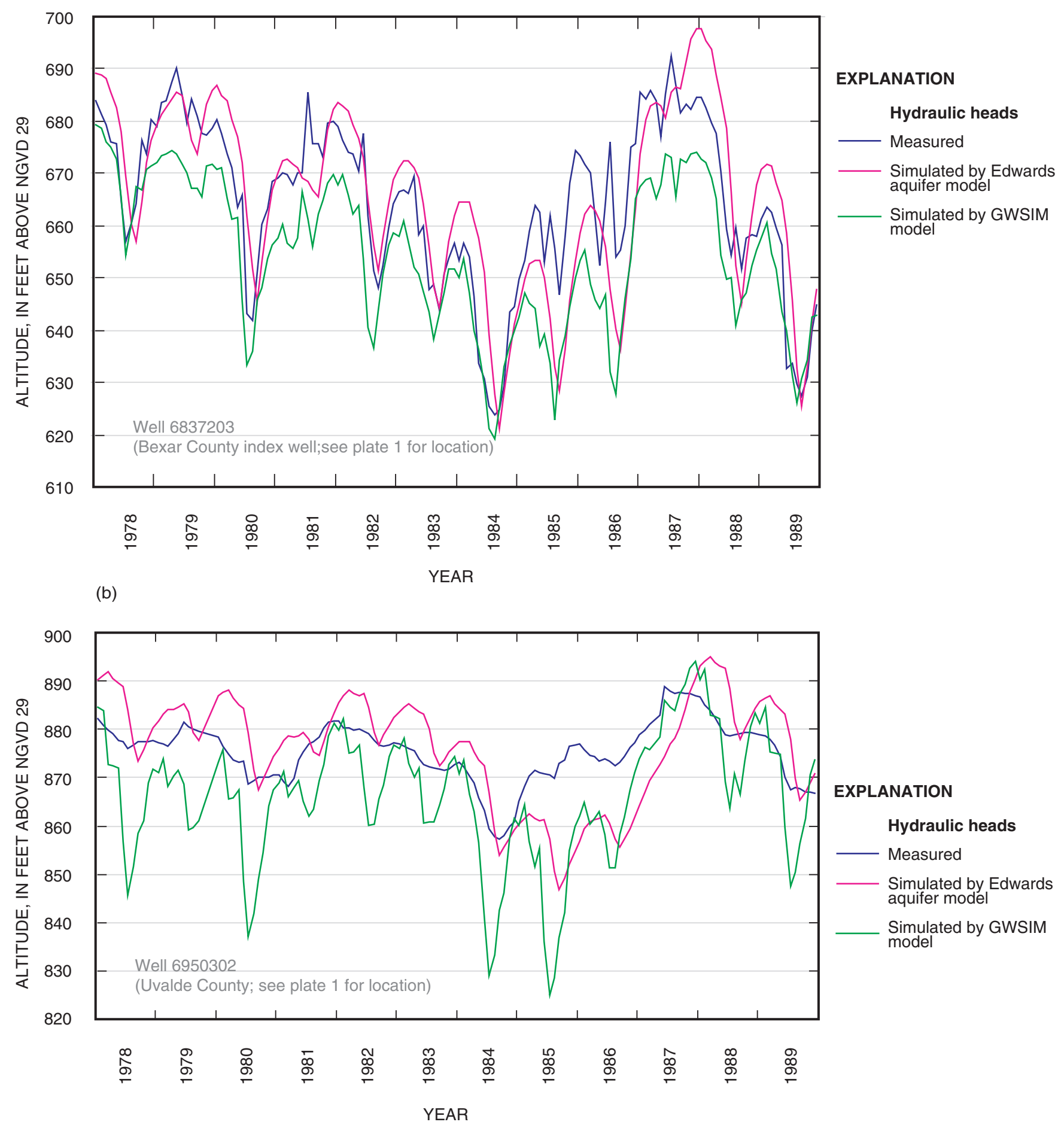

Figure 37. Measured hydraulic heads and simulated hydraulic heads by the Edwards aquifer model, San Antonio region, Texas, and the GWSIM model for (a) Bexar County index well $(\mathrm{J}-17,6837203)$ and (b) Uvalde County index well $(\mathrm{J}-27,6950302), 1978-89$.

greater simulated fluctuations in hydraulic heads than the measured fluctuations for wells located in and near the recharge zone, resulting in poor matches between simulated and mea- sured hydraulic heads. In contrast, the statistical measures for the Edwards aquifer model for springflow and most observation wells in the confined zone of the aquifer are relatively small, 
(a)

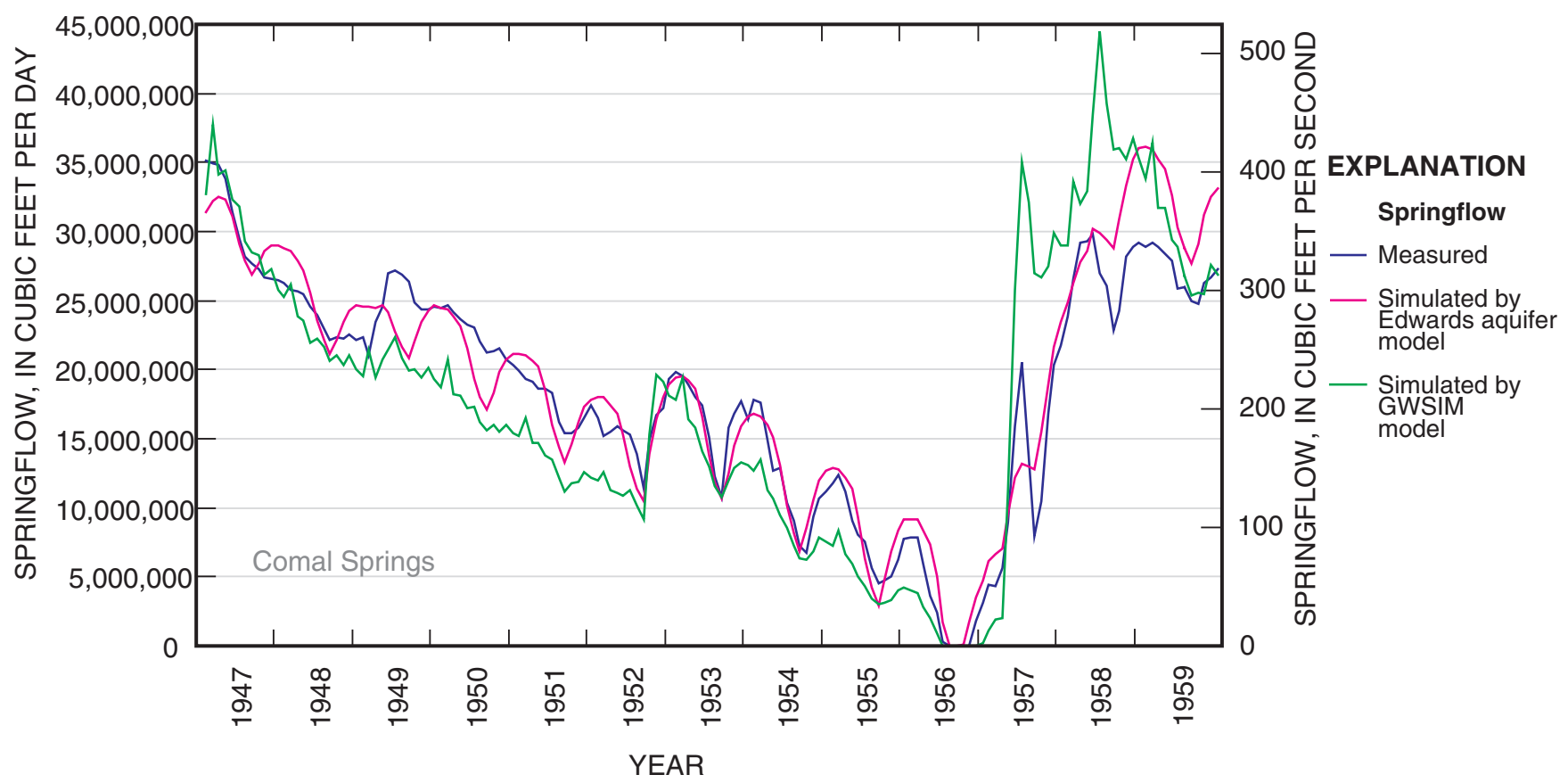

(b)

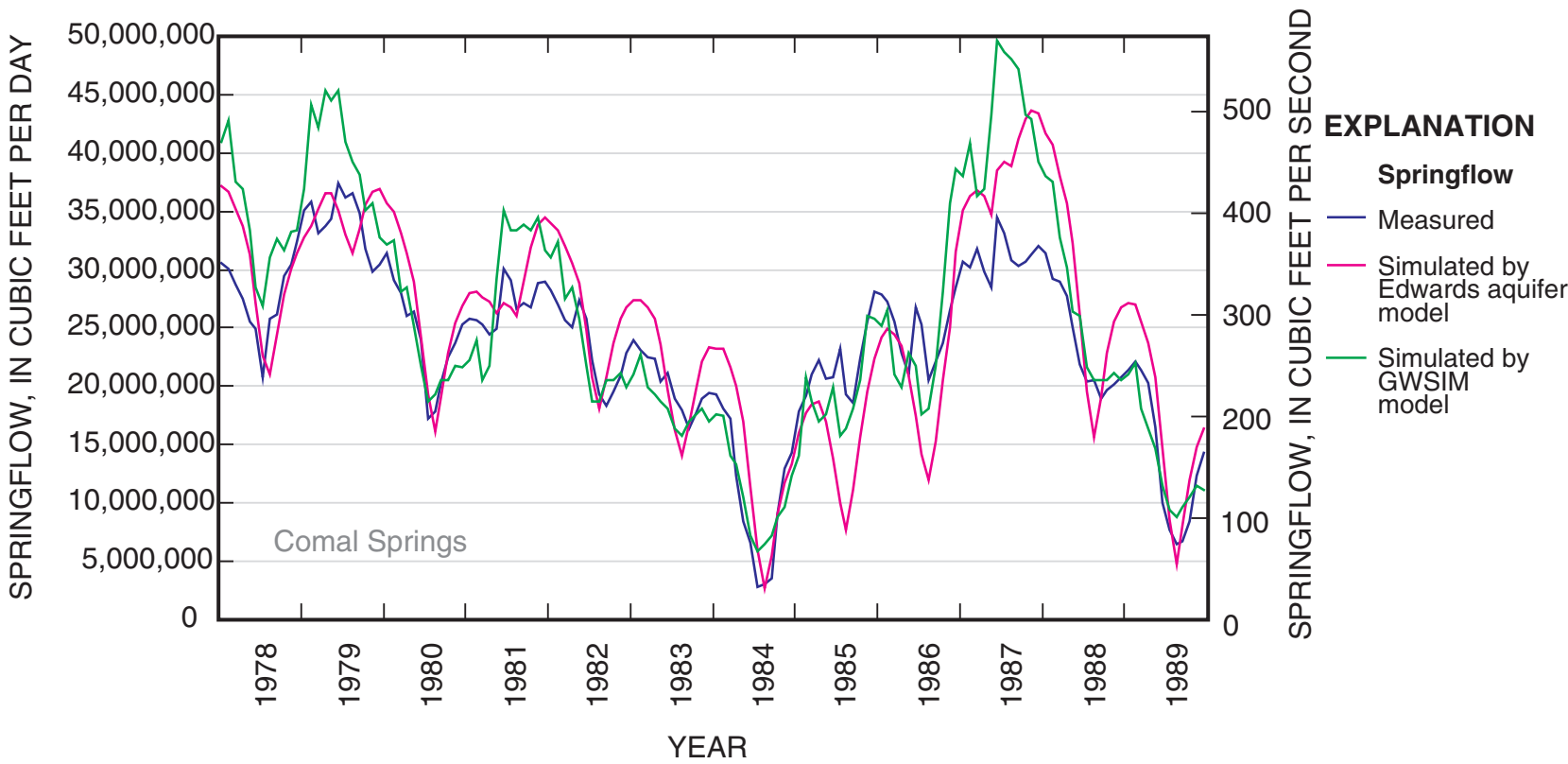

Figure 38. Measured springflows and simulated springflows by the Edwards aquifer model, San Antonio region, Texas, and the GWSIM model for Comal Springs for (a) 1947-59 and (b) 1978-89.

which indicates a close match between simulated and measured hydraulic heads and springflows. The appreciably close match between simulated and measured springflows achieved in the Edwards aquifer model, as compared to GWSIM, is partially a result of the comparatively small specific yields simulated in the Edwards aquifer model. Increasing simulated specific yields, and to a lesser extent specific storage, would produce an improved match between simulated and measured hydraulic heads for observation wells in and near the recharge zone, but at the same time would appreciably lessen the match between simulated and measured springflows. To match both measured hydraulic heads in and near the recharge zone (unconfined conditions) and measured springflows and hydraulic heads in the confined zone of the aquifer equally well, the dual-porosity 
(a)
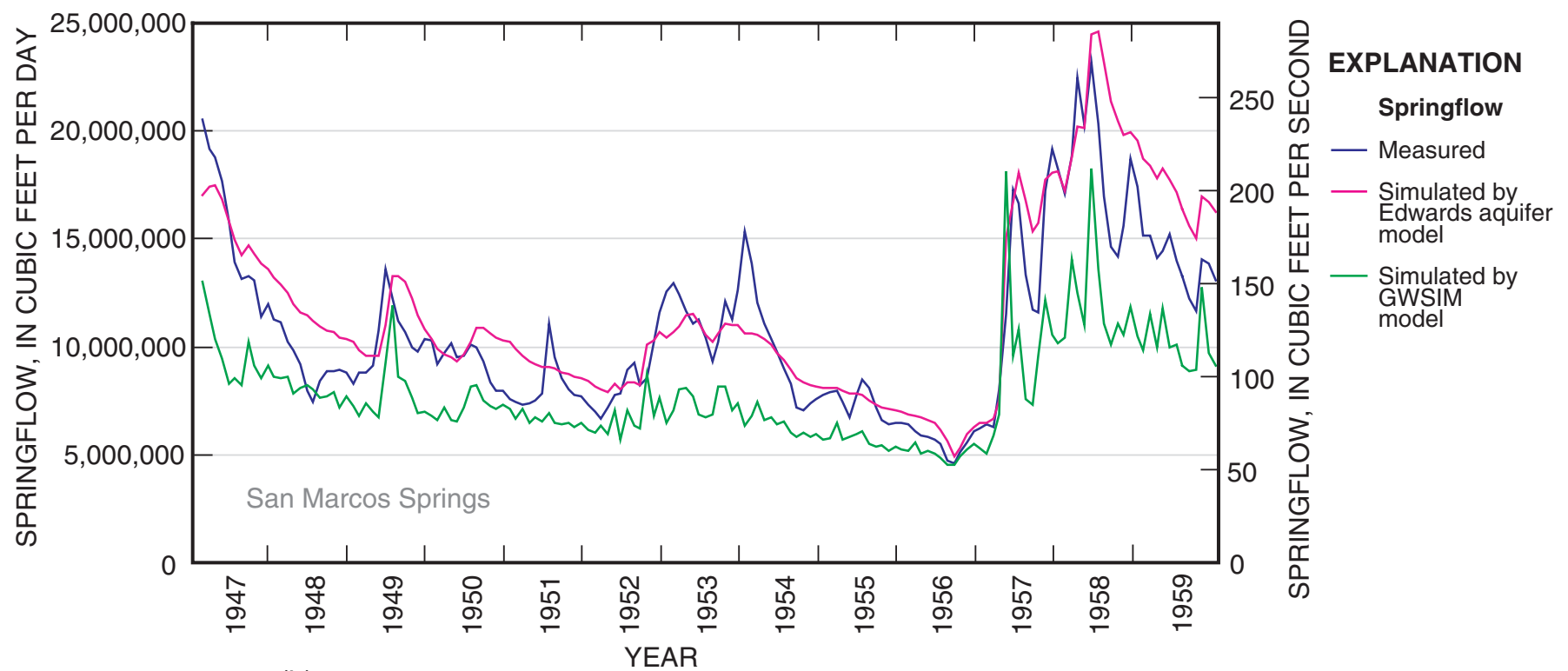

(b)

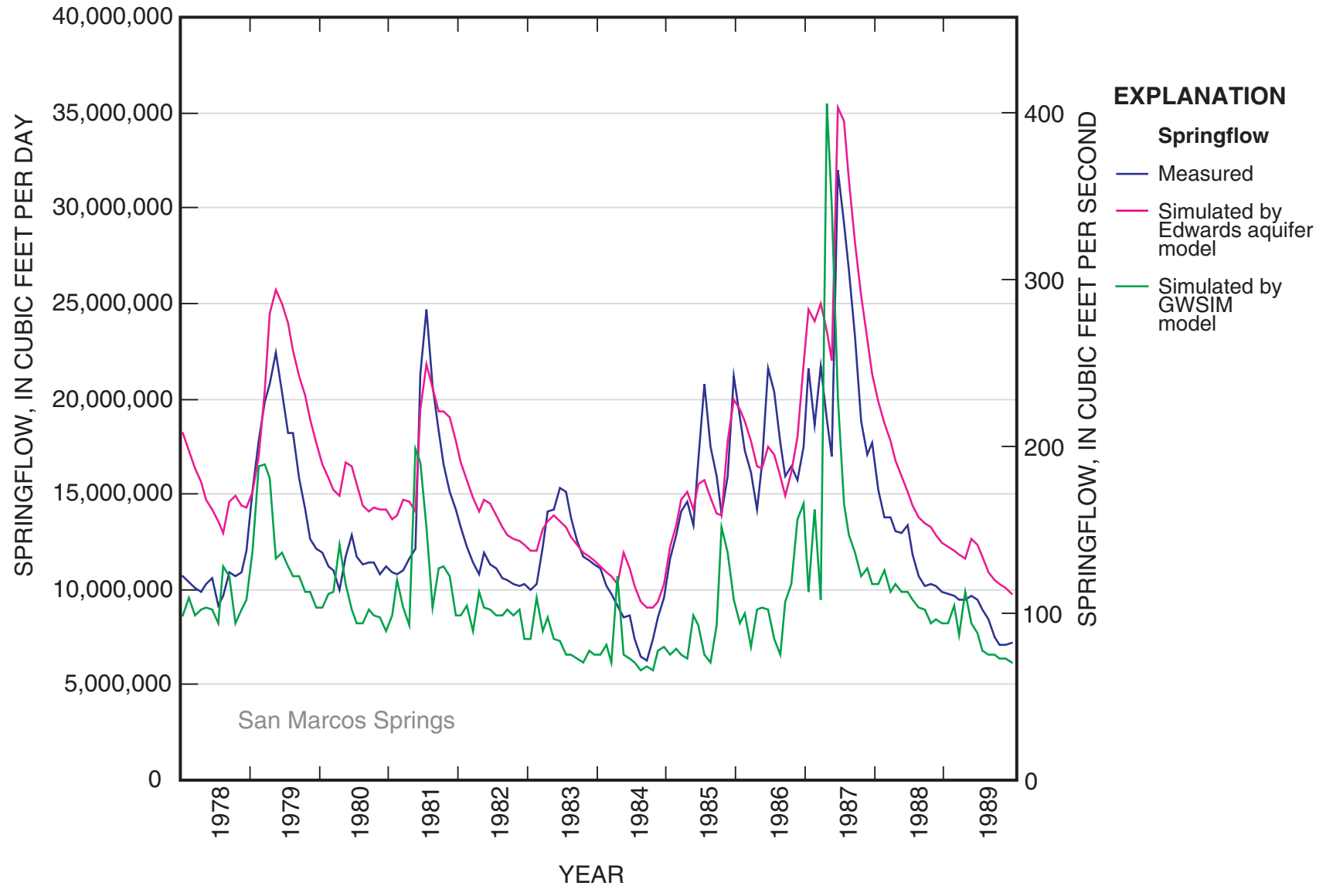

Figure 39. Measured springflows and simulated springflows by the Edwards aquifer model, San Antonio region, Texas, and the GWSIM model for San Marcos Springs for (a) 1947-59 and (b) 1978-89.

(matrix, and fracture and conduit) nature of the Edwards aquifer, particularly in the recharge zone, probably would need to be incorporated to a greater degree into the simulation. Calibration of the Edwards aquifer model for the recharge zone and areas of unconfined conditions near the recharge zone was minimal because of a lack of hydrogeologic and hydrologic information 
(a)

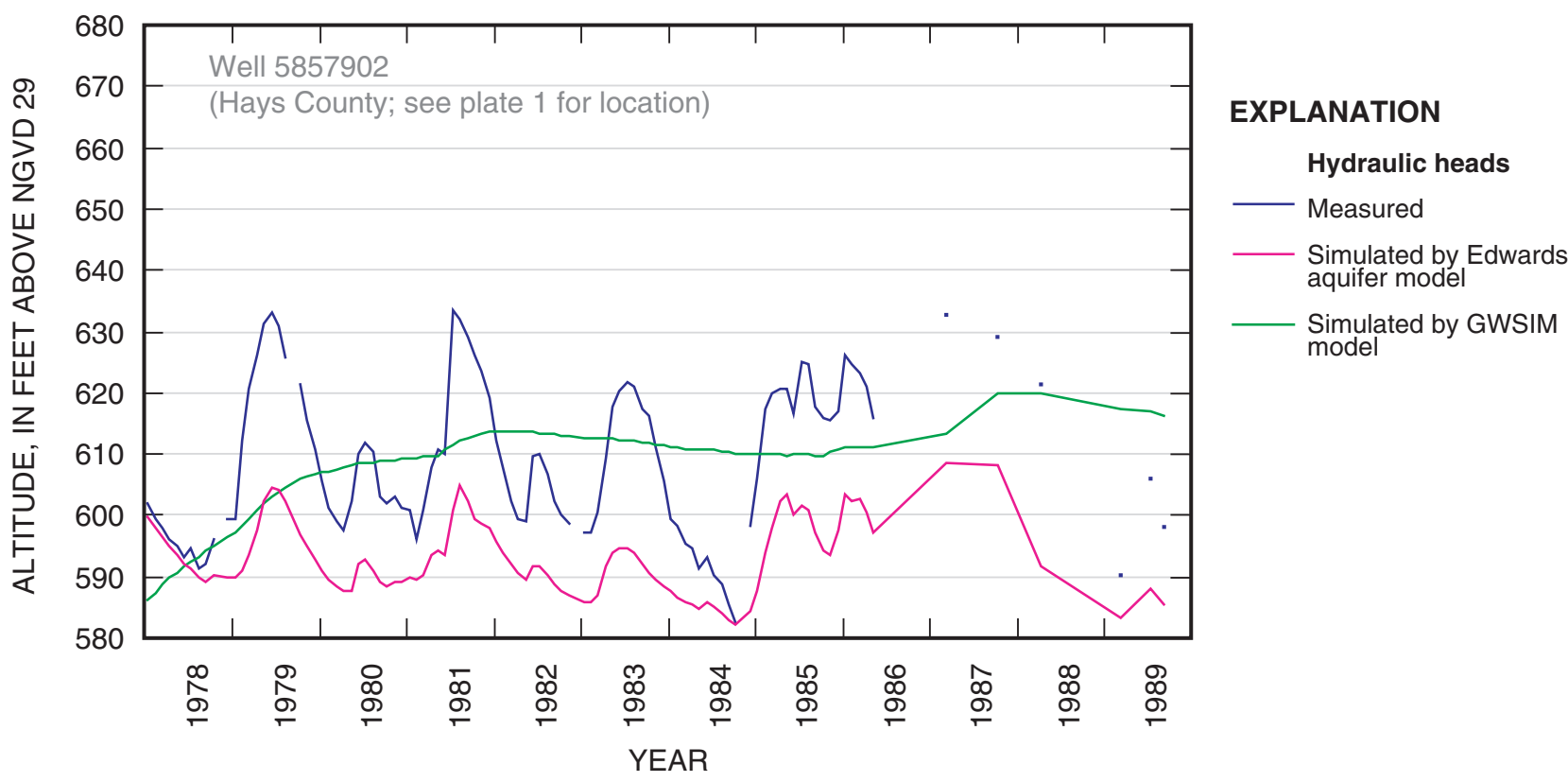

(b)

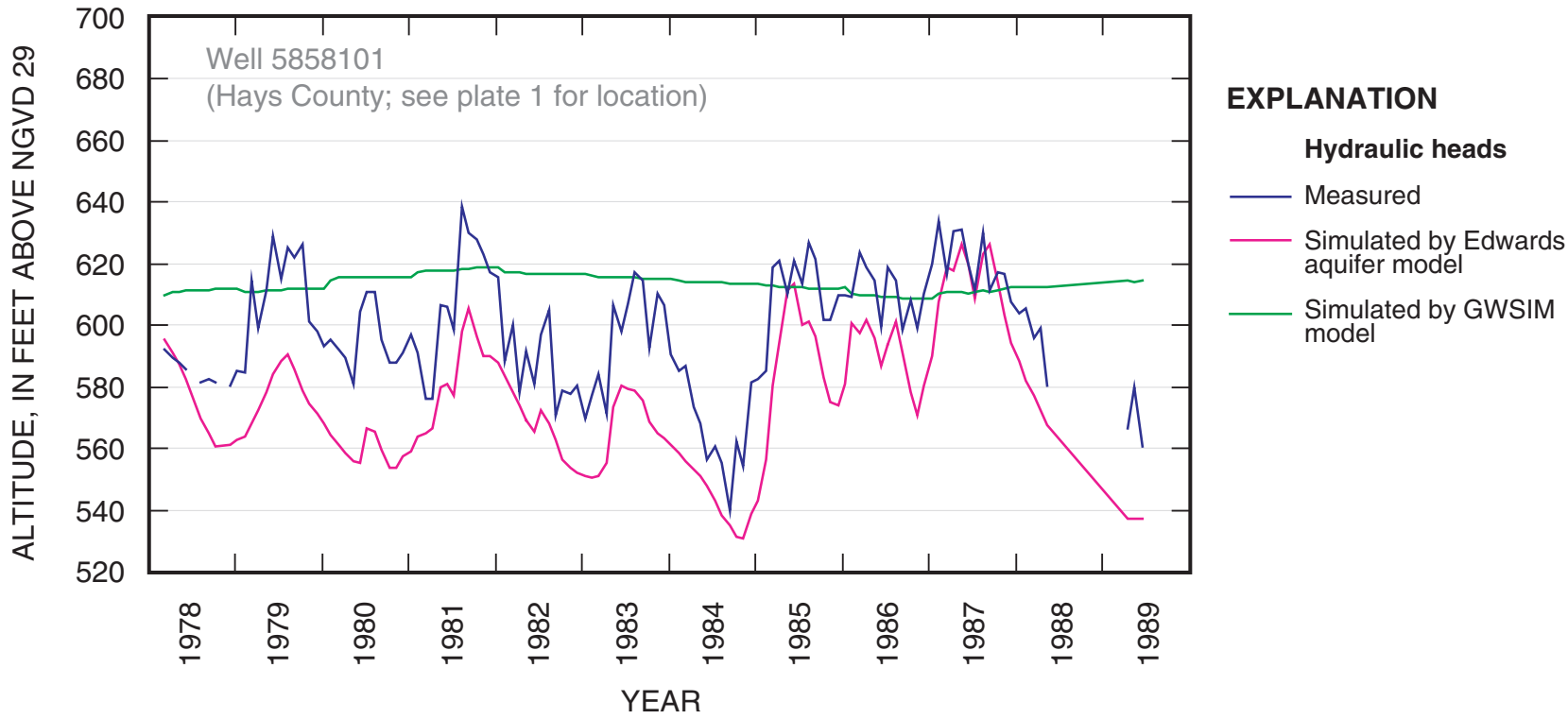

Figure 40a, b. Measured hydraulic heads and simulated hydraulic heads by the Edwards aquifer model, San Antonio region, Texas, and the GWSIM model for Hays County wells (a) 5857902, (b) 5858101, 1978-89.

and the priority given to matching measured springflows and hydraulic heads in the confined zone of the aquifer.

\section{Model Limitations}

All numerical ground-water-flow models are simplifications of the real system and, therefore, have limitations.
Limitations generally result from assumptions used to develop the conceptual and numerical models, limitations in the quality and quantity of the input data, and the scale at which the model can be applied. In addition, a combination of input values to the model different from those used in the calibrated simulations could produce the same result; the solution is nonunique. 
(c)

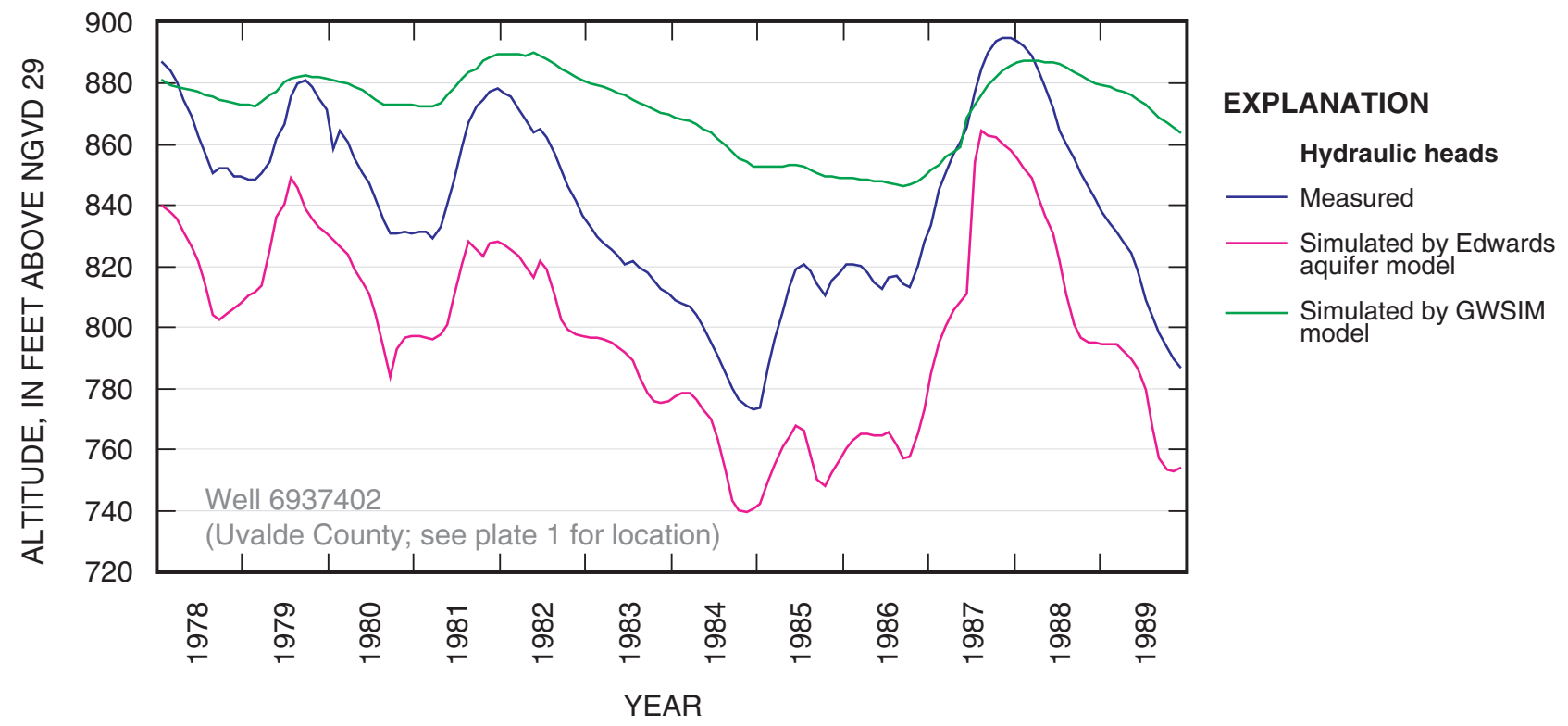

Figure 40c. Measured hydraulic heads and simulated hydraulic heads by the Edwards aquifer model, San Antonio region, Texas, and the GWSIM model for Uvalde County well 6937402, 1978-89.

\section{Assumptions For Conceptual and Numerical Models}

Use of a distributed, porous media model to simulate flow in a karst system is a simplification, and the model will not be able to simulate some aspects of flow accurately in this system, particularly the effects of rapid and potentially turbulent flow in conduits. This simplification is not critical for many waterresources-management applications, and the Edwards aquifer model was able to simulate measured variations in springflow over time, as well as fluctuations in water levels in monitoring wells. The Edwards aquifer model is not able to simulate travel times for contaminants in the aquifer system and should not be used for this purpose. The incorporation of turbulent flow in conduits potentially could facilitate a better simulation of ground-water flow and transport in the Edwards aquifer, but such models are not yet commercially available and would require the collection of more field data.

Further model limitations include the discretization of the model grid and the temporal discretization for the transient simulation. The model simulates the Edwards aquifer as one composite layer with vertically averaged hydraulic properties and uses relatively coarse 0.25 -mi cell dimensions, with homogeneity of properties within each cell. The transient simulation uses monthly stress periods. Further refinement of the spatial and temporal discretization of the Edwards aquifer model, however, is limited by the quantity and quality of currently (2004) available hydrogeologic information. The Edwards aquifer model did not include the underlying Trinity aquifer in parts of the recharge zone or the confined zone, which in some areas might be sufficiently permeable to contribute to flow in the
Edwards aquifer. Inflow to the Edwards aquifer along the northern model boundary from the adjoining Trinity aquifer in the Hill Country, however, was simulated.

The freshwater/saline-water interface used to define the southern and southeastern boundaries of the Edwards aquifer model was simulated as a no-flow boundary. This representation might not be entirely accurate, particularly during low-flow periods when low gradients might induce inflow from the saline-water side of the interface.

A constant-flux boundary condition was used for the northern model boundary for the transient simulation, on the basis of the assumption that water-level changes in the Trinity aquifer were similar to those in the Edwards aquifer near the boundary during the transient simulation time period (19472000). If this assumption was inaccurate, actual flows across the boundary might differ from the simulated flows. During periods of drought, the simulated inflows across the northern boundary were as much as 42 percent of the simulated recharge to the aquifer (from infiltration of rainfall), while during periods of near-normal or above-normal rainfall northern boundary inflows were less than 10 percent of the simulated recharge. However, Mace and others (2000, p. 137) found no difference in model results after making revisions to hydraulic heads in their corresponding general-head boundary condition (southern and southeastern boundary of the Trinity aquifer Hill Country model) to account for water-level declines near the boundary, compared to the results prior to these revisions.

In simulating faults and their effects on ground-water flow in the Edwards aquifer model, the assumption was made that the effectiveness of a fault as a barrier to flow perpendicular to the 
fault is proportional to the fault displacement. This assumption is a simplification of the actual flow system and might not be true in all cases. Hovorka and others (1998) indicated that faults can either increase or decrease total transmissivity and might not necessarily act as barriers to ground-water flow. Also, as simulated in the Edwards aquifer model, conduits in many areas cut through faults and lessen or eliminate their flow-barrier effect. However, in some areas such as in northern Medina County, measured water levels indicate steep hydraulic gradients across major faults, and these are correctly approximated in the model.

\section{Limitations of Input Data}

Model limitations also are associated with input data. The input datasets for the Edwards aquifer model are based on sparse information for some parameters and in some areas. In particular, the final storativity distribution in the model was developed by model calibration because of the lack of available data on which to base an initial variable distribution. Also, hydrogeologic data are relatively meager for the recharge zone, for the Kinney County area, and for areas south of the 1,000$\mathrm{mg} / \mathrm{L}$ dissolved solids concentration line. Water-level data for constructing potentiometric surfaces and well hydrographs might affect the evaluation of the goodness of fit of the model because comparisons of simulated and measured water levels are limited to areas where water levels have been measured. In particular, comparatively few water-level measurements are available for the recharge zone of the Edwards aquifer and south of the 1,000-mg/L dissolved solids concentration line. Recharge data for the area of this model generally are considered much more accurate than are available for many other regions. However, the need to modify the simulated recharge rates during periods of above-normal rainfall and recharge indicates that recharge estimates used in the model might not be entirely accurate and warrant further analysis. The principal errors in the estimates of annual recharge, as computed by the USGS, are related to errors in estimating runoff in ungaged areas, which represent about 30 percent of the recharge area. The estimated long-term average annual recharge in each basin, however, probably is representative of the actual recharge because the averaging procedure tends to cancel out the major errors (Garza, 1962; Puente, 1978). Therefore, the use of annual recharge estimates to compute recharge for a more frequent time-step, as was done for the Edwards aquifer model (monthly transientsimulation stress periods), could increase the error associated with recharge estimates. Monthly estimates of recharge during periods of high runoff probably contain the major errors (Puente, 1978). Only diffuse recharge was simulated for the Guadalupe River Basin within the Edwards aquifer recharge zone (Guadalupe River recharge subzone) in the Edwards aquifer model, because the USGS reports that the Guadalupe River does not contribute appreciable recharge to the aquifer. However, the diffuse recharge simulated was similar in magnitude to the recharge rates estimated for the Guadalupe River recharge subzone by HDR Engineering, Inc. (1998). They estimated that annual recharge occurring in this zone was as much as 20,363 acre-ft during 1990-96, but represents less than 2 percent of the long-term (1934-96) average recharge for the San Antonio segment of the Edwards aquifer. Diffuse recharge within the recharge subzones and streambed recharge along the stream reaches in the upstream part of the recharge subzones were distributed uniformly because of a lack of information on spatial focusing of recharge in particular locations.

Withdrawals by wells were compiled and distributed temporally and spatially for the Edwards aquifer model. As for recharge estimates, the distribution and rates of withdrawals might not be entirely accurate and warrant further analysis. Factors contributing to uncertainty in temporal and spatial distribution of simulated withdrawals include (1) incomplete information for well location and construction, (2) lack of withdrawal data for individual wells before the Well Metering Program of EAA was begun in 1998, and (3) the need to temporally and spatially distribute withdrawals on the basis of parameters other than individual withdrawal rates. For example, withdrawal rates were assigned to individual wells on the basis of total county withdrawals, water-use category, and the number of wells in the respective category. Also, monthly rates for irrigation were varied in proportion to the average (1954-2000) deficit of rainfall minus lake evaporation. Rates of withdrawals for most wells before the inception of the Well Metering Program of EAA are unknown. The use of indirect methods to estimate rates of withdrawals might appreciably increase the uncertainty in the estimates. Further refinement of well location and construction information, improvement of databases, and more comprehensive well metering are needed to improve withdrawal estimates.

A fully accurate representation of ground-water flow in the Edwards aquifer model is constrained by lack of knowledge of the location and characteristics of high-permeability zones or conduits. A network of conduits, as postulated by Worthington (2004, fig. 21), was simulated in the Edwards aquifer model, although their locations were inferred from few data and subject to considerable uncertainty. In particular, conduit segments in southeastern Uvalde County, eastern Medina County, northcentral Bexar County, the Cibolo Creek area, and Hays County are based on sparse information and thus are approximately located. Considerable uncertainty also exists regarding the physical dimensions, connectivity, and hydraulic properties of conduits. The physical dimensions of the conduits in the Edwards aquifer model are constrained by the model cell dimensions. The initial distribution of conduits in the model was a continuously connected network of cells. However, model calibration indicated that measured hydraulic heads and springflows were more closely simulated with discontinuities in the conduit network in the Knippa gap area in eastern Uvalde County and in the vicinity of Hueco Springs in Comal County. The hydraulic properties of conduits are difficult to assess because of the low probability of a well intersecting a major conduit in a karst aquifer and their very high permeability if intersected by a well. Few wells drilled actually intersect a conduit, and those that do probably yield no drawdown when 


\section{Summary of important limitations and uncertainties associated with conceptual and numerical models, input data, and scale of application}

1. Assumptions for conceptual and numerical models

a. Use of a distributed, porous media model to simulate flow in a karst system results in

- Inability to simulate rapid, potentially turbulent flow in conduits

- Inability to simulate travel times for contaminants in the aquifer system

b. Discretization of the model grid

- Vertical: one model layer

- Horizontal: relatively coarse cell size

c. Temporal discretization for transient simulation

- Monthly stress periods

d. Representation of boundary conditions

- Placement of the southern model boundary at the $10,000-\mathrm{mg} / \mathrm{L}$ dissolved solids concentration line

- Use of a constant-flux boundary condition for the northern model boundary for the transient simulation

- Assumption that the effectiveness of a fault as a barrier to flow is proportional to the fault displacement

2. Limitations of input data

a. Datasets based on sparse information for some parameters and in some areas

- Parameters and data based on sparse information: (1) storativity distribution and (2) water-level data

- Areas with sparse information: (1) recharge zone, (2) Kinney County, and (3) south of the 1,000-mg/L dissolved solids concentration line

b. Data of uncertain accuracy that warrant further analysis

- Recharge

- Withdrawals by wells

- Location and characteristics of high-permeability zones or conduits

3. Scale of application

a. The Edwards aquifer model is regional in nature, and therefore its application to local, site-specific issues is not appropriate

b. The appreciable local-scale effects of the simulated conduits on ground-water flow in the conduit cells and the nearby model cells contribute to the unsuitability of the Edwards aquifer model for application to subregional areas

specific-capacity and aquifer tests are conducted, thereby providing no quantitative estimates of aquifer properties.

\section{Scale of Application}

The Edwards aquifer model is regional in nature and, therefore, best suited to evaluate variations in spring discharge, regional water-level changes, and the relative comparison of regional water-management scenarios. For example, the model is well suited for making comparisons between various groundwater-withdrawal scenarios from a well field or distributed over a large area, or variations in amounts of recharge to the aquifer and the resultant effects on hydraulic heads and springflows. Accuracy and applicability of the model decrease when changing from the regional to the local scale. The model is not considered appropriate for local issues, such as water-level declines surrounding individual wells, because of the relatively coarse grid size $(1,320 \mathrm{ft})$ and limitations previously described. In addition, corrections for apparent drawdown might be needed to apply model results, calculated for the center of grid cells, to individual wells and their pumping cycles. Local effects and water-level declines depend on site-specific hydraulic properties and hydrologic conditions and thus need to be addressed with a finer grid discretization and with local estimates of hydraulic properties and hydrologic conditions. 


\section{Summary of needed data collection and additional investigations}

1. Data collection
a. Storativity
b. Water-level measurements
c. Withdrawals by wells

2. Area investigations
a. Recharge zone

- Hydrogeologic information, ground-water flow paths

- Spatial variability in recharge rates

- Flow relations between the Edwards and Trinity aquifers

b. Kinney County

- Hydrogeologic information, ground-water flow paths

- Sources of water to Las Moras Springs

- Location of the ground-water-flow divide

c. Southern Uvalde County and Leona Springs

- Hydrogeologic information, ground-water flow paths

- Improved estimates of Leona Springs discharge

3. Other investigations

a. Evaluation of the freshwater/saline-water interface

b. Location and properties of high-permeability zones or conduits

4. Numerical model improvements

a. Improved representation of conduits, possibly as a discrete pipe network, and potentially turbulent flow

b. Incorporation of multiple model layers and smaller grid-cell dimensions

Uncertainty regarding the exact locations of conduits also has implications regarding the scale of application of the model. The simulation of conduits in the model has appreciable localscale effects on ground-water flow in the conduit cells and the nearby model cells. These simulated local-scale effects that result from the presence of simulated conduits, however, are not reliable predictors of flow conditions in these areas because of the high degree of uncertainty regarding the locations of conduits. High fracture and conduit permeability, as opposed to matrix permeability, might or might not exist at the exact location of the simulated conduit. The simulated conduit locations are coarse, approximate, possible locations for actual conduits based on sparse data and are not appropriate for local-scale issues. Also, Worthington (2004) indicated that the 0.25-miwide conduits simulated in the Edwards aquifer model are 20 to 50 times wider than the likely actual width of the major conduits in the Edwards aquifer. In addition, the conduits are simulated as the entire thickness of the aquifer in the one-layer model, but in reality the individual conduits do not penetrate the aquifer from top to bottom. On a regional scale, however, the conduits and background hydraulic-conductivity distribution simulated in the Edwards aquifer model reasonably reproduce measured springflows and hydraulic heads over a relatively long transient calibration period (1947-2000).

\section{Needed Data and Future Work}

The sensitivity analysis for the Edwards aquifer model indicated that the simulated hydraulic heads and springflows are sensitive to variations in the storativity. As is the case in many models, the initial assumption made for the Edwards aquifer model was that the storativity was uniform for unconfined and confined conditions, with specific yield assigned for unconfined conditions and specific storage assigned for confined conditions. This initial assumption was made primarily because of a lack of data. Direct measurements on storativity are few because they typically require paired observation and pumping wells within a radius of influence during an aquifer test. During model calibration, it became apparent that zones of varying storativity were required to simulate 
measured hydraulic heads and springflows in the Edwards aquifer. Geologic controls on storativity include consolidation, cementation, and other diagenetic processes that affect the elasticity of the aquifer matrix. The diagenetic history can be complex, with burial and exhumation resulting in a complex evolution of the elastic properties of the rock. Additional research on how storativity could be estimated on the basis of known or measurable rock properties and burial depth is needed for the Edwards aquifer.

The Edwards aquifer model was able to more accurately simulate measured hydraulic heads in the confined zone of the aquifer than in the recharge zone. This might be because of the karstic, dual- or triple-porosity nature of the aquifer and the simulated comparatively small storativity values for the recharge zone, which are as much as two orders of magnitude less than typical storativity values for unconfined aquifers in other regions. The comparatively small storativity values simulated for the recharge zone in the Edwards aquifer model result in simulated water-level fluctuations tending to be appreciably greater than measured water-level fluctuations for wells in the recharge zone. However, increasing simulated storativity values for the recharge zone, although improving the match between simulated and measured water levels for wells in and near the recharge zone, would worsen the accuracy of the simulation for wells in the confined zone of the aquifer and for springflows. Also, a general lack of hydrogeologic information and knowledge of ground-water flow in the recharge zone, compared to the confined zone, contributes to the poorer match between simulated and measured hydraulic heads in and near the recharge zone and indicates the need for further data compilation and investigations of ground-water flow in the recharge zone. Future studies could investigate spatially variable recharge within the recharge subzones and along the streams, using more local attributes of the geology, soils, and topography. Flow relations between the Edwards aquifer and the Trinity aquifer, particularly in parts of the recharge zone where the Edwards aquifer is thin or unsaturated, also warrant further investigation.

The Edwards aquifer model required the simulation of relatively small hydraulic conductivities near the western model boundary to match the measured hydraulic heads in that area. The hydraulic conductivities for the area in the final calibrated Edwards aquifer model are appreciably lower than those estimated by Painter and others (2002) but are consistent with a low-transmissivity zone simulated by Maclay and Land (1988, fig. 19) for the area in their model. As for the recharge zone, a general lack of hydrogeologic information and knowledge of ground-water flow in Kinney County probably contributes to the need to use possibly unrealistically small hydraulic conductivities in order to approximate measured hydraulic heads near the western model boundary. Further data compilation and investigation of ground-water flow and Las Moras Springs discharge are needed in Kinney County to improve numerical ground-water-flow model simulations of the area.

The Edwards aquifer model results are consistent with recent work indicating that the Leona Springs discharge might be appreciably greater than the discharge estimated and published by the USGS (Green, 2004). The RMS error of the difference between simulated and measured springflows for Leona Springs for the calibrated transient simulation was $2,884,793 \mathrm{ft}^{3} / \mathrm{d}$, which represents 36.6 percent of the range of reported springflows during 1947 to 2000 . This comparatively high RMS error probably is the result of underestimated reported springflows for Leona Springs, with the differences between reported and simulated springflows greatest during the early 1990s (fig. 29a), a period of greatly above-normal rainfall and recharge. Further studies and data collection are needed to better understand ground-water flow in southern Uvalde County and to improve estimates of Leona Springs discharge.

Further studies also are needed to evaluate the freshwater/ saline-water interface used to define the southern and southeastern model boundaries. The potential exists for inflow across the interface, particularly during low-flow periods.

Hovorka and others (2004) and Worthington (2004) discussed indicators of high-permeability zones and conduits and mapped probable conduit locations. Further work and data collection are needed to assess the location and properties of conduits in the Edwards aquifer. Hovorka and others (2004) suggested areas, data-collection needs, and methods for future field work. Suggested detailed study areas included the Leona Springs and Knippa gap areas in Uvalde County, the western part of an inferred conduit system in Medina County, an area including the recharge zone in north-central Bexar County, and areas near the freshwater/saline-water interface in Bexar and Comal Counties (Hovorka and others, 2004, fig. 27). Suggested data-collection needs included water-level measurements at low aquifer water levels and water-chemistry sampling across several recharge events. A hydrograph separation method was suggested as a means to assess the location and properties of conduits. Also, natural tracers were proposed as a method for identifying wells within a conduit system that could be used in future tracer-testing studies because they are likely to intercept introduced tracers.

Future numerical ground-water-flow model simulations of the Edwards aquifer in the San Antonio region potentially would be improved by the simulation of two model layers for the recharge zone of the aquifer, an upper layer with higher storativity values and a lower layer with storativity values similar to those simulated in the Edwards aquifer model. Such a model comprising two simulated layers for the recharge zone with contrasting storativity values also might alleviate the potential problem of simulated hydraulic heads above land surface during periods of greatly above-normal rainfall and recharge.

\section{Summary}

The Edwards aquifer in the Balcones fault zone of southcentral Texas is one of the most permeable and most productive aquifers in the world. To evaluate the hydrologic response to various alternative proposals for managing the Edwards aqui- 
fer, the Edwards Aquifer Authority, together with other San Antonio water-resource managers and planners, expressed the need for an improved numerical ground-water-flow model. To develop an improved model, the U.S. Geological Survey and The University of Texas at Austin, Bureau of Economic Geology, in cooperation with the U.S. Department of Defense and the Edwards Aquifer Authority, conducted a study to improve understanding of the complex hydrogeologic processes that control water availability of the Edwards aquifer in the San Antonio area through the development, calibration, and testing of a numerical ground-water-flow model that can be used in decision processes to optimize resource management.

The Edwards aquifer is part of an aquifer system developed in thick and regionally extensive Lower Cretaceous carbonates that underlie large areas of Texas. The Edwards aquifer is unconfined in the outcrop area (recharge zone) and confined in downdip parts of the Balcones fault zone (confined zone) by overlying hydrogeologic units of small to very small permeability. The confined part of the aquifer includes on its downdip (gulfward) margin a freshwater/saline-water transition zone of brackish water. The altitude of the top of the aquifer ranges from about 1,000 ft above NGVD 29 near the recharge zone in the western part of the active model area to about $4,000 \mathrm{ft}$ below NGVD 29 near the downdip limit of the active model area in Frio County. The aquifer thickness ranges from about $450 \mathrm{ft}$ near the recharge zone in Bexar, Comal, and Hays Counties to about 1,100 ft in Kinney County.

Evidence of the karstic nature of the Edwards aquifer includes outcrop observations, subsurface data, hydrologic information, tracer test results, and biologic data. The principal evidence of flow through karst is the heterogeneous and rapidly responsive nature of water-level variation. Water levels in the aquifer and discharge at springs rise rapidly after rainfall and then decline at a variable rate, showing drainage from rocks characterized by both conduit and matrix permeability. Wells close together can have different responses to a single recharge pulse.

Determining the distribution and characteristics of conduits is difficult. A regionally extensive system of high permeability zones is defined by broad troughs in the potentiometric surface in the confined zone of the Edwards aquifer. Highsalinity water (greater than $3,000 \mathrm{mg} / \mathrm{L}$ dissolved solids concentration) indicative of long residence times is in the deep part of the Edwards aquifer; these areas could be interpreted as regions bypassed by recharge water low in dissolved solids moving through conduits. About 5 percent of the water samples from the confined zone of the Edwards aquifer are greatly undersaturated with respect to calcite, which is interpreted as an indicator of rapid conduit flow with little reaction between rock and water. Particularly favorable sites for development of conduits are grabens and synclines. Major structural troughs, where increased flow and conduit development are favored, have been identified in the San Antonio segment of the Edwards aquifer.

The locations of conduits were inferred for inclusion in the Edwards aquifer model. The inferred locations of the conduits were based on a number of factors, including major potentio- metric-surface troughs in the aquifer, the presence of sinking streams, geochemical information, and geologic structures (for example, faults and grabens). The locations of confined-zone conduit segments are based on potentiometric-surface troughs, geologic structure, and preferential development of conduits near the freshwater/saline-water interface. In addition, the major sinking streams were interpreted to be connected to the major springs by conduits in the Edwards aquifer model.

Matrix, fracture, and conduit permeability occur in the Edwards aquifer. The highest matrix permeability occurs in downdip parts of the Edwards aquifer, where mixing of freshwater and saline water has maximized dolomite dissolution. Outcrops, which are at the highest altitudes, show abundant dissolution features and additional karst features that have developed in near-surface settings; however, matrix porosity and permeability of outcrop rocks are low relative to those in the aquifer.

Hydraulic conductivity and transmissivity in the Edwards aquifer each vary over eight orders of magnitude and are multimodal. Mean hydraulic conductivity of the confined zone is more than 120 times greater than mean hydraulic conductivity in the recharge zone. Vertical variations in hydraulic conductivity in the Edwards aquifer indicate that the entire aquifer is highly permeable, as well as highly variable. Statistical comparison of transmissivities from tests in wells at varying distances from mapped faults shows no strong relation between high transmissivity and proximity to faults. The hydraulic conductivity of the Edwards aquifer in the San Antonio region, from estimates developed using a combination of spatial statistical methods and advanced techniques for automatic model calibration, ranged from less than or equal to 20 to $7,347 \mathrm{ft} / \mathrm{d}$.

Conduits could be major contributors to flow in the Edwards aquifer. The contribution of matrix permeability to regional-scale hydraulic conductivity likely is minor and most Edwards aquifer water flows through fractures and conduits. Inferred conduits and major flow paths occur from central Bexar County to western Medina County, with an east-west trend that might indicate a structural influence. The presence of conduits and major flow paths also are indicated (1) in a potentiometric-surface trough that loops northward around volcanic intrusions in southeastern Uvalde County, (2) along parts of the freshwater/saline-water interface in Medina and western Bexar Counties, (3) mostly near the freshwater/saline-water interface between Comal Springs and eastern Bexar County, and (4) in a large graben system within the outcrop in southern Comal County.

The primary source of recharge to the Edwards aquifer is seepage from streams crossing the outcrop (hence, the outcrop is synonymous with the recharge zone). Estimates of the combined recharge to the San Antonio segment of the Edwards aquifer from stream seepage and infiltration of rainfall range from a low of 43,700 acre-ft during 1956 to a high of 2,486,000 acre-ft during 1992. The Edwards aquifer in much of the Balcones fault zone is juxtaposed against the Trinity aquifer both at the surface and at depth, and the Trinity aquifer likely discharges directly into the Edwards aquifer. Estimates of this flow 
range from 2 to 9 percent of the average estimated annual recharge to the Edwards aquifer.

Most discharge from the Edwards aquifer occurs as (1) withdrawals by industrial, irrigation, and public-supply wells, and (2) springflow. Springflow from the San Antonio segment of the aquifer totaled 69,800 acre-ft in 1956 during the 1950s drought and reached a record high of 802,800 acre-ft in 1992. Total ground-water withdrawals by wells in the San Antonio segment of the aquifer increased steadily at an average annual rate ofabout 4,500 acre-ft/yr, more than tipling between 1939 and 2000. In Bexar, Hays, Kinney, and Travis Counties, municipal water withdrawals account for more than 85 percent of total ground-water withdrawals. Irrigation accounts for more than 60 percent of withdrawals in Uvalde County and more than 80 percent in Medina County. Comal and San Marcos Springs are the largest springs, with total discharges of 274,800 and 195,900 acre-ft, respectively, in 2002.

Water levels in the Edwards aquifer do not show a longterm decline as a result of ground-water withdrawals. The aquifer is dynamic, with water levels generally responding to temporal and spatial variations in recharge and ground-water withdrawals. During periods of drought, water levels decline but recover rapidly in response to recharge. The drought of the early 1950s is documented by downward trends of water-level hydrographs. The hydrographs indicate periods of rapid rises in water levels in 1957, 1973, 1981, 1987, 1991, 1992, and 1998. These rises in water levels reflect appreciable recharge that resulted from large amounts of rainfall in the catchment area and recharge zone. The highest water levels occurred in the early 1990s.

A numerical model of ground-water flow, the Edwards aquifer model, was constructed on the basis of the conceptual model of the Edwards aquifer. As a way to represent conduits, other than by use of a coupled-continuum pipe flow or dualporosity or triple-porosity model, conduits are simulated in the Edwards aquifer model by narrow (one cell, 0.25 -mi wide), initially continuously connected zones with large hydraulicconductivity values. The initial distribution of conduits formed a continuously connected system of large hydraulic-conductivity cells that links ground-water flow from the recharge zone and the western parts of the model area to Comal and San Marcos Springs in the eastern part of the San Antonio segment of the Edwards aquifer. Model calibration, however, indicated a need to simulate a break in thiscontinuous system of simulated conduits in southeastern Uvalde and southwestern Medina Counties.

For the steady-state simulation, the mean absolute difference between simulated and measured hydraulic heads is 19.4 $\mathrm{ft}$ and the mean algebraic difference is $4.5 \mathrm{ft}$, indicating that positive differences were approximately balanced by negative differences. The root mean square (RMS) error is $26.5 \mathrm{ft}$, which represents about 4 percent of the total head differenceacross the model area. The closest-match simulated springflows were within 3 and 13 percent of the median springflows for Comal and San Marcos Springs, respectively.
The closest-match simulated hydraulic heads for the transient simulation for a period of below-normal rainfall were within $30 \mathrm{ft}$ of measured water levels at 140 of the 171 wells for which water-level data were available. The RMS error is $45.5 \mathrm{ft}$, which represents about 6 percent of the total head difference across the model area. The closest-match simulated hydraulic heads for a period of above-normal rainfall were within $30 \mathrm{ft}$ of measured water levels at 129 of the 169 wells for which water-level data were available. The RMS error is 33.5 $\mathrm{ft}$, which represents about 5 percent of the total head difference across the model area.

The transient simulation for 1947-2000 acceptably reproduces measured fluctuations in hydraulic heads over time in the Edwards aquifer. The match between simulated and measured hydraulic heads generally is closer for wells completed in the confined part of the aquifer than for those in and near the recharge zone. The RMS error ranged from 4.1 to $23.2 \mathrm{ft}$ in 11 wells with water-level measurements for varying periods during 1947-2000, and these errors represent 7.8 to 30.8 percent of the range in water-level fluctuations of each of those wells.

Generally acceptable agreement also was obtained between simulated and measured flow at the simulated springs. The RMS errors for Comal, San Marcos, Leona, San Antonio, and San Pedro Springs ranged from 230,700 $\mathrm{ft}^{3} / \mathrm{d}$ for San Pedro Springs to $3,967,000 \mathrm{ft}^{3} / \mathrm{d}$ for Comal Springs. The RMS errors for the five springs, as a percentage of the range of springflow fluctuations measured at the springs, varied from 7.0 percent for San Marcos Springs to 36.6 percent for Leona Springs and were less than 10 percent for all but Leona Springs. The mean algebraic differences between simulated and measured springflows are 6.7 and $15.0 \mathrm{ft}^{3} / \mathrm{s}$ for Comal and San Marcos Springs, respectively, indicating a small bias in the residuals toward high flows.

A ground-water divide in the Edwards aquifer occurs near Kyle in south-central Hays County, from which ground-water flow is to the east toward Barton Springs or to the west toward San Marcos Springs. Model simulation results indicate that the position of this ground-water divide varies, depending on the water-level conditions. For steady-state and above-normal rainfall and recharge conditions, the simulated position of the ground-water divide is coincident with its commonly defined position near Kyle. In contrast, during drought conditions the position of the simulated ground-water divide shifts westward to near San Marcos Springs.

Model simulation results indicate that the simulated flow in the Edwards aquifer is strongly influenced by the locations of the simulated conduits, which tend to convey flow. The simulated subregional flow directions generally are toward the nearest conduit and subsequently along the conduits from the recharge zone into the confined zone and toward the major springs. The influence of simulated barrier faults on flow directions is most evident in northern Medina County. In this area, the direction of ground-water flow is affected primarily by parallel northeastward-striking faults and conduit segments that divert flow toward the southwest. 
A water budget is an accounting of inflow to, outflow from, and storage change in the aquifer. The water budget is balanced when total sources equal total discharges equal total flow (including change in storage) through the aquifer. For the steady-state simulation, recharge accounts for 93.5 percent of the sources of water to the Edwards aquifer and inflow through the northern and northwestern model boundaries contributes 6.5 percent. The largest discharges are springflow (73.7 percent) and withdrawals by wells ( 25.7 percent). The principal source of water to the Edwards aquifer (excluding change in storage) for the transient simulation is recharge. The principal discharges from the Edwards aquifer (excluding change in storage) for the transient simulation are springflow and withdrawals by wells. During 1956, representing drought conditions, the greatest discharge was withdrawals by wells, followed by springflow. During 1975, representing above-normal rainfall and recharge conditions, the greatest discharge was springflow, followed by withdrawals. During 1956, the change in storage (net water released from storage) was much greater than recharge, accounting for 75.9 percent of total flow compared to 14.5 percent for recharge. Conversely, during 1975, recharge constituted 79.9 percent of total flow (including change in storage). The amount and percentage of water released from storage is large during 1956 (drought conditions) because recharge is small and more water is required from storage to meet the withdrawal demands. In contrast, during 1975 (above-normal rainfall and recharge conditions) the amount of recharge exceeded the withdrawal demand and springflow in some months, with a resulting net gain in storage to the aquifer for the year.

A series of sensitivity tests was made to ascertain how the model results were affected by variations greater than and less than the calibrated values of input data. Simulated hydraulic heads in the Edwards aquifer model were most sensitive to recharge, withdrawals, hydraulic conductivity of the conduit segments, and specific yield and relatively insensitive to springorifice conductance for Comal and San Marcos Springs, northern boundary inflow, and specific storage. Moving the simulated southern no-flow model boundary northward from the $10,000-\mathrm{mg} / \mathrm{L}$ dissolved solids concentration line to the $1,000-$ $\mathrm{mg} / \mathrm{L}$ dissolved solids concentration line resulted in lower water levels in the Bexar County index well and higher water levels in the Uvalde County index well. The effect of lowering the simulated spring-orifice altitudes for Comal and San Marcos Springs was to appreciably lower hydraulic heads in the aquifer, because the spring-orifice altitudes serve as a controlling base level for hydraulic heads in the aquifer.

As for hydraulic heads, simulated springflows in the Edwards aquifer model were most sensitive to recharge, withdrawals, hydraulic conductivity of the conduit segments, and specific yield and were relatively insensitive to spring-orifice conductance, northern boundary inflow, and specific storage. However, springflow is more sensitive to increases in northern boundary inflow than are hydraulic heads. Larger values of hydraulic conductivity, coupled with reduced recharge, resulted in smaller simulated springflows. If the reduced recharge is accounted for, however, larger values of hydraulic conductivity result in increased springflow. Moving the simulated southern no-flow model boundary northward from the $10,000-\mathrm{mg} / \mathrm{L}$ dissolved solids concentration line to the $1,000-\mathrm{mg} / \mathrm{L}$ dissolved solids concentration line resulted in reduced springflow for Comal Springs and increased springflow for Leona Springs. The effect of lowering the simulated spring-orifice altitudes for Comal and San Marcos Springs from calibrated levels to initial levels was to minimally increase springflow for Comal Springs and appreciably decrease springflow for Leona Springs. The appreciable reduction in springflow that occurred for Leona Springs was because of the lowering of hydraulic heads in the aquifer.

Hydraulic heads and springflows simulated by the Edwards aquifer model for selected observation wells and springs were compared to the corresponding hydraulic heads and springflows simulated by the GWSIM model. The mean absolute difference, the RMS error of the residuals, and the RMS error divided by the range in measured hydraulic head for the Edwards aquifer model are appreciably smaller than those for GWSIM for two time periods (1947-59 and 1978-89) for the Bexar County index well and for San Marcos Springs, and for the 1947-59 time period for Comal Springs. The statistical measures for the Edwards aquifer model generally are larger than those for GWSIM for the observation wells in and near the recharge zone (unconfined conditions), indicating a generally poorer match between simulated and measured hydraulic heads. The statistical measures for the Edwards aquifer model and GWSIM generally are similar for observation wells in the confined zone of the aquifer.

The residual statistics (mean absolute difference and RMS error of the residuals) in some cases are not a complete measure of the goodness of fit between the simulated and measured hydraulic heads. In the case of three wells, the hydrographs indicate that the Edwards aquifer model more accurately simulates the magnitude and pattern of fluctuations in measured water levels than does GWSIM, although the residual statistics are smaller for GWSIM than for the Edwards aquifer model.

The goodness of fit between simulated and measured hydraulic heads and springflows also is influenced by the time period of the comparison. For four of eight wells used as calibration targets in the Edwards aquifer model and in the comparisons with GWSIM, the residual statistics for the longer Edwards aquifer model calibration period (generally 19472000) were smaller (indicating a closer match between simulated and measured hydraulic heads) than those for the shorter time period (1978-89) available for comparison with GWSIM. For three of the eight wells, the residual statistics for the Edwards aquifer model for the longer time period were smaller than the residual statistics for the 1978-89 time period for GWSIM.

All numerical ground-water-flow models are simplifications of the real system and, therefore, have limitations. Limitations generally result from assumptions used to develop the conceptual and numerical models, limitations in the quality and quantity of the input data, and the scale at which the model can 
be applied. Use of a distributed, porous media model to simulate flow in a karst system is a simplification, and the model will not be able to simulate some aspects of flow accurately in this system, particularly the effects of rapid and potentially turbulent flow in conduits. Further model limitations include the discretization of the model grid and the temporal discretization for the transient simulation.

Model limitations also are associated with input data. The input datasets for the Edwards aquifer model are based on sparse information for some parameters and in some areas. In particular, the final storativity distribution in the model was developed by model calibration because of a lack of available data on which to base an initial variable distribution. Also, hydrogeologic data are relatively meager for the recharge zone, for the Kinney County area, and for areas south of the 1,000$\mathrm{mg} / \mathrm{L}$ dissolved solids concentration line. The need to modify the simulated recharge rates during periods of above-normal rainfall and recharge indicates that recharge estimates used in the model might not be entirely accurate and warrants further analysis. A fully accurate representation of ground-water flow in the Edwards aquifer model also is constrained by lack of knowledge of the location and characteristics of highpermeability zones or conduits. A network of conduits was simulated in the Edwards aquifer model, although their locations were inferred from few data and subject to considerable uncertainty. Considerable uncertainty also exists regarding the physical dimensions, connectivity, and hydraulic properties of conduits.

The Edwards aquifer model is regional in nature and, therefore, best suited to evaluate variations in spring discharge, regional water-level changes, and the relative comparison of regional water-management scenarios. Accuracy and applicability of the model decrease when changing from the regional to the local scale. Local effects and water-level declines depend on site-specific hydraulic properties and hydrologic conditions and thus need to be addressed with a finer grid discretization and with local estimates of hydraulic properties and hydrologic conditions. The simulated conduit locations are coarse, approximate, possible locations for actual conduits based on sparse data and are not appropriate for local-scale issues.

The Edwards aquifer model was able to more accurately simulate measured hydraulic heads in the confined zone of the aquifer than in the recharge zone. This might be because of the karstic, dual- or triple-porosity nature of the aquifer and the simulated relatively small storativity values for the recharge zone. Also, a general lack of hydrogeologic information and knowledge of ground-water flow in the recharge zone, compared to the confined zone, contributes to the poorer match between simulated and measured hydraulic heads in and near the recharge zone and indicates the need for further data compilation and investigations of ground-water flow in the recharge zone. Flow relations between the Edwards aquifer and the Trinity aquifer, particularly in parts of the recharge zone where the Edwards aquifer is thin or unsaturated, also warrant further investigation.
Further data compilation and investigation of groundwater flow and Las Moras Springs discharge are needed in Kinney County to improve numerical ground-water-flow model simulations of the area. Further studies and data collection also are needed to better understand ground-water flow in southern Uvalde County and improve estimates of Leona Springs discharge. In addition, further studies are needed to evaluate the freshwater/saline-water interface used to define the southern and southeastern model boundaries and to assess the locations and properties of conduits in the Edwards aquifer.

\section{References Cited}

Abbott, P.L., 1975, Calcitization of Edwards Group dolomites in the Balcones fault zone aquifer, south central Texas: Geology, v. 2, no. 7, p. 359-362.

Alexander, K.B., 1990, Correlation of structural lineaments and fracture traces to water-well yields in the Edwards aquifer, Central Texas: Austin, University of Texas, Masters Thesis, $113 \mathrm{p}$.

Arnow, Ted, 1963, Ground-water geology of Bexar County, Texas: U.S. Geological Survey Water-Supply Paper 1588, 36 p. [Also published as Texas Board of Water Engineers Bulletin 5911, 62 p., 1959.]

Ashworth, J.B., 1983, Ground-water availability of the Lower Cretaceous Formations in the Hill Country of south central Texas: Texas Department of Water Resources Report 273, $173 \mathrm{p}$.

Atkinson, T.C., 1977, Diffuse flow and conduit flow in limestone terrain in the Mendip Hills, Somerset (Great Britain): Journal of Hydrology, v. 35, no. 1-2, p. 93-110.

Atkinson, T.C., and Smart, P.L., 1981, Artificial tracers in hydrogeology in A survey of British hydrogeology 1980: London, The Royal Society, p. 173-190.

Baker, E.T., Jr., Slade, R.M., Jr., Dorsey, M.E., Ruiz, L.M., and Duffin, G.L., 1986, Geohydrology of the Edwards aquifer in the Austin area, Texas: Texas Water Development Board Report 293, 215 p.

Barker, R.A., and Ardis, A.F., 1996, Hydrogeologic framework of the Edwards-Trinity aquifer system, west-central Texas: U.S. Geological Survey Professional Paper 1421-B, 61 p.

Barrett, M.E., and Charbeneau, R.J., 1996, A parsimonious model for simulation of flow and transport in a karst aquifer: Technical Report Center for Research in Water Resources, Report 269, 149 p.

Bathurst, R.G.C., 1975, Carbonate sediments and their diagenesis-Developments in sedimentology 12 ( $2 \mathrm{~d}$ ed.): New York, Elsevier, 658 p.

Bauer, Sebastian, Liedl, Rudolf, and Sauter, Martin, 2003, Modeling of karst aquifer genesis-Influence of exchange flow [abs.]: Water Resources Research, v. 39, no. 10, p. 1,285 . 
Bennett, R.R., and Sayre, A.N., 1962, Geology and groundwater resources of Kinney County, Texas: Texas Water Commission Bulletin 6216, 176 p.

Berner, R.A., and Morse, J.W., 1974, Dissolution kinetics of calcium carbonate in sea water-IV, Theory of calcite dissolution: American Journal of Science, v. 274, p. 108-134.

Birk, Steffen, Bauer, Sebastian, Liedl, Rudolf, and Sauter, Martin, 2003, Coupling a pipe-network to MODFLOW to predict the evolution of karst aquifers in Poeter, E.P., Zheng, C., Hill, M.C., and Doherty, John, eds., MODFLOW and more 2003-Understanding through modeling, Golden, Colo., September 16-19, 2003, Proceedings: Colorado School of Mines, p. 65-69.

Brune, Gunnar, 1975, Major and historical springs of Texas: Texas Water Development Board Report 189, 103 p. [Available from National Technical Information Service, Springfield, VA 22161 as NTIS report PB-296 524/2.]

Brune, Gunnar, and Duffin, G.L., 1983, Occurrence, availability, and quality of ground water in Travis County, Texas: Texas Department of Water Resources Report 276, 219 p.

Burchett, C.R., Rettman, P.L., and Boning, C.W., 1986, Edwards aquifer, extremely productive, but ... A sole-source water supply for San Antonio and surrounding counties in south central Texas: San Antonio, Edwards Underground Water District report, $38 \mathrm{p}$.

Campana, M.E., and Mahin, D.A., 1985, Model-derived estimates of groundwater mean ages, recharge rates, effective porosities and storage in a limestone aquifer: Journal of Hydrology, v. 76, no. 3/4, p. 247-264.

Clark, A.K., 2003, Geologic framework of the Edwards aquifer, Uvalde County, Texas: U.S. Geological Survey WaterResources Investigations Report 03-4010, 17 p.

Clark, A.K., and Small, T.A., 1997, Geologic framework of the Edwards aquifer and upper confining unit, and hydrogeologic characteristics of the Edwards aquifer, south central Uvalde County, Texas: U.S. Geological Survey WaterResources Investigations Report 97-4094, 11 p.

Clement, T.J., 1989, Hydrochemical facies in the badwater zone of the Edwards aquifer, central Texas: Austin, University of Texas, Masters Thesis, $168 \mathrm{p}$.

Collins, E.W., 1995, Structural framework of the Edwards aquifer, Balcones fault zone, central Texas, in John, C.J., and Byrnes, M.R., eds., Transactions of the 45th Annual Convention of the Gulf Coast Association of Geological Societies, a section of the American Association of Petroleum Geologists regional meeting and the 42nd Annual Convention of the Gulf Coast Section of the Society of Economic Paleontologists and Mineralogists, Baton Rouge, La., October 25-27, 1995: p. 135-142.

Collins, E.W., 2000, Geologic map of the New Braunfels 30" X 60" quadrangle: Austin, University of Texas, Bureau of Economic Geology Miscellaneous Map 39.

Collins, E.W., and Hovorka, S.D., 1997, Structure map of the San Antonio segment of the Edwards aquifer and Balcones fault zone, south-central Texas-Structural framework of a major limestone aquifer-Kinney, Uvalde, Medina, Bexar,
Comal and Hays Counties: Austin, University of Texas, Bureau of Economic Geology Miscellaneous Map 38.

Cronin, S., 1932, Disconformity between Edwards and Georgetown in Hays and Comal Counties: Austin, University of Texas, Masters Thesis, $32 \mathrm{p}$.

DeCook, K.J., 1963, Geology and ground-water resources of Hays County, Texas: U.S. Geological Survey Water-Supply Paper 1612, 72 p.

Deike, R.G., 1990, Dolomite dissolution rates and possible Holocene dedolomitization of water-bearing units in the Edwards aquifer, south-central Texas: Journal of Hydrology, v. 112 , no. 3-4, p. 335-373.

Dreybrodt, W., 1996, Principles of early development of karst conduits under natural and man-made conditions revealed by mathematical analysis of numerical models: Water

Resources Research, v. 32, no. 9, p. 2,923-2,935.

Edwards Aquifer Authority, 2004a, Habitat conservation plan: accessed September 21, 2004, at URL http://www.edwardsaquifer.org/Pages/theplans/habitat.html

Edwards Aquifer Authority, 2004b, Edwards aquifer optimization program/reports: accessed September 21, 2004, at URL http://www.edwardsaquifer.org/Pages/theaquifer/ esearch_optimize.html

Elliott, W.R., and Veni, George, eds., 1994, The caves and karst of Texas-Guidebook for the 1994 convention of the National Speleological Society with emphasis on the southwestern Edwards Plateau: Huntsville, Ala., National Speleological Society, $342 \mathrm{p}$.

Environmental Simulations, Inc., 2002, Guide to using Groundwater Vistas: Reinholds, Pa., Environmental Simulations, Inc., 266 p.

Esquilin, Roberto, comp., 2004, Edwards aquifer bibliography through 2003: Edwards Aquifer Authority Report 04-01, $198 \mathrm{p}$.

Ewing, T.E., 1991, Structural framework, in Salvador, Amos, ed., The Gulf of Mexico Basin: Geological Society of America, Geology of North America, v. J, p. 31-52.

Ferrill, D.A., and Morris, A.P., 2003, Dilatational normal faults: Journal of Structural Geology, v. 25, p. 183-196.

Fisher, W.L., and Rodda, P.U., 1969, Edwards Formation (Lower Cretaceous), Texas dolomitization in a carbonate platform system: American Association of Petroleum Geologists Bulletin, v. 53, no. 1, p. 55-72.

Flawn, P.T., 1964, Basement rocks of the Texas Gulf Coastal Plain: Transactions of the Gulf Coast Association of Geological Societies, v. 14, p. 271-275.

Gale, S.J., 1984, The hydraulics of conduit flow in carbonate aquifers: Journal of Hydrology, v. 70, p. 309-327.

Garza, Sergio, 1962, Recharge, discharge, and changes in ground-water storage in the Edwards and associated limestones, San Antonio area, Texas-A progress report on studies, 1955-59: Texas Board of Water Engineers Bulletin $6201,51 \mathrm{p}$.

Garza, Sergio, 1966, Ground-water resources of the San Antonio area, Texas-A progress report on studies, 1960-64: Texas Water Development Board Report 34, 36 p. 
Garza, Sergio, 1968, Aquifer characteristics from well-field production records, Edwards Limestone, San Antonio area, Texas: Tucson, University of Arizona, Masters Thesis, 46 p. George, W.O., 1952, Geology and ground-water resources of Comal County, Texas: U.S. Geological Survey WaterSupply Paper 1138, 126 p.

Green, R.T., 2004, Geophysical survey to determine the depth and lateral extent of the Leona aquifer and evaluation of discharge through the Leona River floodplain, south of Uvalde, Texas: Contract report to Edwards Aquifer Authority, 17 p.

Groschen, G.E., 1996, Hydrogeologic factors that affect the flowpath of water in selected zones of the Edwards aquifer, San Antonio region, Texas: U.S. Geological Survey WaterResources Investigations Report 96-4046, 73 p.

Halihan, Todd, Mace, R.E., and Sharp, J.M., 2000, Flow in the San Antonio segment of the Edwards aquifer-Matrix, fractures, or conduits?, in Sasowsky, I.D., and Wicks, C.M., Groundwater flow and contaminant transport in carbonate aquifers: Brookfield, Vt., A.A. Balkema, p. 129-146.

Halihan, Todd, Sharp, J.M., Jr., and Mace, R.E., 1999, Interpreting flow using permeability at multiple scales, in Palmer, A.N., Palmer, M.V., and Sasowsky, I.D., eds., Karst modeling: Karst Waters Institute, Special Publication 5, p. 82-96.

Hamilton, J.M., Johnson, S., Esquilin, R., Thompson, E.L., Luevano, G., Wiatrek, A., Mireles, J., Gloyd, T., Sterzenback, J., Hoyt, J.R., and Schindel, G., 2003, Edwards Aquifer Authority hydrogeological data report for 2002: San Antonio, Edwards Aquifer Authority, 134 p. [Available online at www.edwardsaquifer.org]

Hanson, J.A., and Small, T.A., 1995, Geologic framework and hydrogeologic characteristics of the Edwards aquifer outcrop, Hays County, Texas: U.S. Geological Survey WaterResources Investigations Report 95-4265, 10 p.

Harbaugh, A.W., Banta, E.R., Hill, M.C., and McDonald, M.G., 2000, MODFLOW-2000, the U.S. Geological Survey modular ground-water model-User guide to modularization concepts and the ground-water flow process: U.S. Geological Survey Open-File Report 00-92, 121 p.

Harbaugh, A.W., and McDonald, M.G., 1996, User's documentation for MODFLOW-96, an update to the U.S. Geological Survey modular finite-difference ground-water flow model: U.S. Geological Survey Open-File Report 96-485, 56 p.

Hauwert, N.M., Johns, D.A., and Sharp, J., 2002, Evidence of discrete flow in the Barton Springs segment of the Edwards aquifer, in Martin, J.B., Wicks, C.M., and Sasowsky, I.D., eds., Hydrogeology and biology of post-Paleozoic carbonate aquifers: Karst Waters Institute, Special Publication 7, p. 62-167.

Hauwert, N.M., Sansom, J.W., Jr., Johns, D.A, and Aley, T.A., 2002, Groundwater tracing study of the Barton Springs segment of the Edwards aquifer, southern Travis and northern Hays Counties, Texas: Austin, Barton Springs/Edwards Aquifer Conservation District and City of Austin Watershed Protection Department, 96 p.

Hauwert, N.M., and Vickers, S., 1994, Barton Springs/Edwards aquifer hydrogeology and groundwater quality: Barton
Springs/Edwards Aquifer Conservation District, report prepared for Texas Water Development Board under contract no. 93483-346, 92 p.

HDR Engineering, Inc., 1998, Trans-Texas water program, west central study area, phase 2-Edwards aquifer recharge update: San Antonio, Tex., San Antonio River Authority and others [variously paged].

HDR Engineering, Inc., and Espey, Huston \& Associates, Inc., 1993, Guadalupe-San Antonio River Basin recharge enhancement study: San Antonio, Edwards Underground Water District, $3 \mathrm{v}$.

HDR Engineering, Inc., and Geraghty and Miller, Inc., 1991, Regional water supply planning study, phase I-Nueces River Basin, v. 1: Uvalde, Tex., Nueces River Authority and others [variously paged].

Holt, C.L.R., Jr., 1959, Geology and ground-water resources of Medina County, Texas: U.S. Geological Survey WaterSupply Paper 1422, 213 p. [Also published as Texas Board of Water Engineers Bulletin 5601, 278 p., 1956.]

Hovorka, S.D., 1998, Facies and diagenesis of the Austin Chalk and controls on fracture intensity-A case study from north central Texas: The University of Texas at Austin, Bureau of Economic Geology Geological Circular 98-2, 47 p.

Hovorka, S.D., Dutton, A.R., Ruppel, S.C., and Yeh, J.S., 1996, Edwards aquifer ground-water resources-Geologic controls on porosity development in platform carbonates, South Texas: The University of Texas at Austin, Bureau of Economic Geology Report of Investigations 238, 75 p.

Hovorka, S.D., and Mace, R.E., 1997, Interplay of karst, fractures, and permeability in the Cretaceous Edwards aquifer-Analogs for fractured carbonate reservoirs: Society of Petroleum Engineers Annual Conference and Exhibition, Geological Field Trip Guidebook, 35 p.

Hovorka, S.D., Mace, R.E., and Collins, E.W., 1995, Regional distribution of permeability in the Edwards aquifer-Final report: San Antonio, Edwards Underground Water District Report 95-02, 128 p. [Also in Gulf Coast Association of Geological Societies Transactions, v. 45, p. 259-266.].

Hovorka, S.D., Mace, R.E., and Collins, E.W., 1998, Permeability structure of the Edwards aquifer, south Texas-Implications for aquifer management: Austin, University of Texas, Bureau of Economic Geology Report of Investigations 250, $55 \mathrm{p}$.

Hovorka, S.D., Phu, T., Nicot, J.P., and Lindley, A., 2004, Refining the conceptual model for flow in the Edwards aquifer-Characterizing the role of fractures and conduits in the Balcones fault zone segment: Contract report to Edwards Aquifer Authority, $53 \mathrm{p}$.

Hovorka, S.D., Ruppel, S.C., Dutton, A.R., and Yeh, J.S., 1993, Edwards aquifer storage assessment, Kinney County to Hays County, Texas: San Antonio, Edwards Underground Water District, 109 p.

Huntoon, P.W., 1995, Is it appropriate to apply porous media groundwater circulation models to karstic aquifers?, in El-Kadi, A.I., ed., Groundwater models for resources analy- 
sis and management: Boca Raton, Lewis Publishers, p. 339-358.

Johnson, S.B., Schindel, G.M., and Hoyt, J.R., 2002, Groundwater chemistry changes during a recharge event in the karstic Edwards aquifer, San Antonio, Texas: Geological Society of America, Online Abstract 186-8.

Klemt, W.B., Knowles, T.R., Edler, G.R., and. Sieh, T.W., 1979, Ground-water resources and model applications for the Edwards (Balcones fault zone) aquifer in the San Antonio region: Texas Water Development Board Report 239, 88 p.

Klimchouk, A.B., Ford, D.C., Palmer, A.N., and Dreybrodt, Wolfgang, eds., 2000, Speleogenesis-Evolution of karst aquifers: Huntsville, Ala., National Speleological Society, $527 \mathrm{p}$.

Krejca, J.K., 2002, Genetic relatedness of aquifer organisms as a tool for determining aquifer connectedness, in Martin, J.B., Wicks, C.M., and Sasowsky, I.D., eds. Hydrogeology and biology of post-Paleozoic carbonate aquifers: Karst Waters Institute, Special Publication 7, p. 157-161.

Kuniansky, E.L., 1994, Multi-layer finite element model of the Edwards and Trinity aquifers central Texas, in Dutton, A.R., ed., Toxic substances and the hydrologic sciences: Minneapolis, American Institute of Hydrology, p. 234-249.

Kuniansky, E.L., and Holligan, K.Q., 1994, Simulations of flow in the Edwards-Trinity aquifer system and contiguous hydraulically connected units, west-central Texas: U.S. Geological Survey Water-Resources Investigations Report 93-4039, $40 \mathrm{p}$.

Larkin, T.J., and Bomar, G.W., 1983, Climatic atlas of Texas: Texas Department of Water Resources LP-192, 151 p.

LBG-Guyton Associates, 1995, Edwards aquifer ground-water divides assessment, San Antonio region, Texas: San Antonio, Edwards Underground Water District Report 95-01, 35 p.

LBG-Guyton Associates, 1996, A regionwide evaluation of GWSIM-IV model results for the Edwards aquifer: Memorandum Report, $3 \mathrm{p}$.

Liedl, R., Sauter, M., Hückinghaus, D., Clemens, T., and Teutsch, G., 2003, Simulation of the development of karst aquifers using a coupled continuum pipe flow model: Water Resources Research, v. 39, no. 3, p 1,057-1,067.

Lohman, S.W., 1972, Ground-water hydraulics: U.S. Geological Survey Professional Paper 708, 70 p.

Lohman, S.W., and others, 1972, Definitions of selected ground-water terms-Revisions and conceptual refinements: U.S. Geological Survey Water-Supply Paper 1988, 21 p.

Long, A.T., 1962, Ground-water geology of Edwards County, Texas: Texas Water Commission Bulletin 6208, 123 p.

Longley, Glen, 1981, The Edwards aquifer-Earth's most diverse ground-water ecosystem: International Journal of Speleology, v. 11, p. 123-128.

Longley, Glen, 1986, The biota of the Edwards aquifer and the implications for paleozoogeography, in Abbott, P.L., and Woodruff, C.M., Jr., eds., The Balcones escarpment-geology, hydrology, ecology and social development in central Texas: Geological Society of America, p. 51-54.
Lowry, R.L., 1955, Recharge to Edwards ground-water reservoir: Consultant report to San Antonio City Water Board, $66 \mathrm{p}$.

Lozo, F.E., Jr., and Smith, C.I., 1964, Revision of Comanche Cretaceous stratigraphic nomenclature, southern Edwards Plateau, southwest Texas: Gulf Coast Association of Geological Societies Transactions, v. 14, p. 285-306.

Mace, R.E., 2000, Determination of transmissivity from specific capacity tests in a karst aquifer: Ground Water, v. 35, no. 5, p. 738-742.

Mace, R.E., Chowdhury, A.H., Anaya, Roberto, and Way, S.C., 2000, Groundwater availability of the Trinity aquifer, Hill Country area, Texas-Numerical simulations through 2050: Texas Water Development Board Report 353, 169 p.

Mace, R.E., Fisher, R.S., Welch, D.M., and Parra, S.P., 1997, Extent, mass, and duration of hydrocarbon plumes from leaking petroleum storage tank sites in Texas: Austin, University of Texas, Bureau of Economic Geology Geological Circular $01,52 \mathrm{p}$.

Mace, R.E., and Hovorka, S.D., 1997, Quantification and spatial distribution of matrix and conduit porosity and permeability in a karst aquifer, in Annual Meeting of the Geological Society of America, Salt Lake City, Utah, October 20-23, 1997: Geological Society of America Abstracts with Programs, v. 29, no. 6, p. 183.

Mace, R.E., and Hovorka, S.D., 2000, Estimating porosity and permeability in a karstic aquifer using core plugs, well tests, and outcrop measurements, in Sasowsky, I.D., and Wicks, C.M., Groundwater flow and contaminant transport in carbonate aquifers: Brookfield, Vt., A.A. Balkema, p. 93-111.

Maclay, R.W., 1989, Edwards aquifer in the San Antonio region-Its hydrogeology and management: South Texas Geological Society Bulletin, v. 30, no. 4, p. 11-28.

Maclay, R.W., 1995, Geology and hydrology of the Edwards aquifer in the San Antonio area, Texas: U.S. Geological Survey Water-Resources Investigations Report 95-4186, $64 \mathrm{p}$.

Maclay, R.W., and Land, L.F., 1988, Simulation of flow in the Edwards aquifer, San Antonio region, Texas, and refinements of storage and flow concepts: U.S. Geological Survey Report Water-Supply Paper 2336-A, 48 p.

Maclay, R.W., and Rettman, P.L., 1973, Regional specific yield of the Edwards aquifer and associated limestones in the San Antonio, Texas, area: U.S. Geological Survey Open-File Report 73-172, 14 p. [Also published as Edwards Underground Water District Report, 10 p., 1973.]

Maclay, R.W., Rettman, P.L., and Small, T.A., 1980, Hydrochemical data for the Edwards aquifer in the San Antonio area, Texas: Texas Department of Water Resources LP-131, $38 \mathrm{p}$.

Maclay, R.W., and Small, T.A., 1976, Progress report on geology of the Edwards aquifer, San Antonio area, Texas, and preliminary interpretation of borehole geophysical and laboratory data on carbonate rocks: U.S. Geological Survey Open-File Report 76-627, 65 p. 
Maclay, R.W., and Small, T.A., 1983, Hydrostratigraphic subdivisions and fault barriers of the Edwards aquifer, south central Texas: Journal of Hydrology, v. 61, no. 1-3, p. 127-146.

Maclay, R.W., and Small, T.A., 1984, Carbonate geology and hydrology of the Edwards aquifer in the San Antonio area, Texas: U.S. Geological Survey Open-File Report 83-537, 72 p. [Also published as Texas Water Development Board Report 296, 90 p., 1986.]

Maclay, R.W., Small, T.A., and Rettman, P.L., 1980, Waterlevel, recharge, discharge, specific-capacity, well-yield, and aquifer-test data for the Edwards aquifer in the San Antonio area, Texas: Texas Department of Water Resources LP-133, $83 \mathrm{p}$.

Maclay, R.W, Small, T.A., and Rettman, P.L., 1981, Application and analysis of borehole data for the Edwards aquifer in the San Antonio area, Texas. Texas Department of Water Resources LP-131, 88 p.

Mahin, D.A., and Campana, M.E., 1983, Discrete-state compartment model of a limestone ground-water reservoirThe Edwards aquifer near San Antonio, Texas: University of Nevada, Desert Research Institute, Water Resources Center Publication 41077, $41 \mathrm{p}$.

McDonald, M.G., and Harbaugh, A.W., 1988, A modular threedimensional finite-difference ground-water flow model: U.S. Geological Survey, Techniques of Water-Resources Investigations, book 6, chap. A1 [variously paged].

Menard, J.A., comp., 1995, Bibliography of the Edwards aquifer, Texas, through 1993: U.S. Geological Survey Open-File Report 95-336, 75 p.

National Oceanic and Atmospheric Administration, National Climatic Data Center, 1992, Monthly station normals of temperature, precipitation, and heating and cooling degree days, 1961-90, Texas: U.S. Department of Commerce, v. 97, no. 81 [variously paged].

Oetting, G.C., 1995, Evolution of fresh and saline groundwaters in the Edwards aquifer, central Texas-Geochemical and isotopic constraints on processes of fluid-rock interaction and fluid mixing: Austin, University of Texas, Masters Thesis, $203 \mathrm{p}$.

Oetting, G.C., Banner, J.L., and Sharp, J.M., Jr., 1996, Regional controls on the geochemical evolution of saline groundwaters in the Edwards aquifer, central Texas: Journal of Hydrology, v. 181 , no. $1-4$, p. 251-283.

Ogden, A.E., Quick, R.A., and Rothermel, S.R., 1986, Hydrochemistry of the Comal, Hueco, and San Marcos Springs, Edwards, aquifer, Texas, in Abbott, P.L., and Woodruff, C.M., Jr., eds., The Balcones escarpment—Geology, hydrology, ecology and social development in central Texas: Geological Society of America, p. 115-130.

Ogden, A.E., Quick, R.A., Rothermel, S.R., and Lundsford, D.L., 1986, Hydrological and hydrochemical investigation of the Edwards aquifer in the San Marcos area, Hays County, Texas: San Marcos, Tex., Edwards Aquifer Research and Data Center, 364 p.
Painter, Scott, Jiang, Yefang, and Woodbury, Allan, 2002, Edwards aquifer parameter estimation project final report: Southwest Research Institute [variously paged].

Palmer, A.N., 1991, Origin and morphology of limestone caves: Geological Society of America Bulletin, v. 103, p. 1-21.

Pavlicek, Dianne, Small, T.A., and Rettman, P.L., 1987, Hydrologic data from a study of the freshwater zone/saline water zone interface in the Edwards aquifer, San Antonio Region, Texas: U.S. Geological Survey Open-File Report 87-389, $108 \mathrm{p}$.

Peacock, D.C.P., and Sanderson, D.J., 1994, Geometry and development of relay ramps in normal fault systems: American Association of Petroleum Geologists Bulletin, v. 78, no. 2, p. 147-165.

Pearson, F.J., Jr., and Rettman, P.L., 1976, Geochemical and isotopic analyses of waters associated with the Edwards Limestone aquifer, central Texas: San Antonio, Edwards Underground Water District Report, $35 \mathrm{p}$.

Pearson, F.J., Jr., Rettman, P.L., and Wyerman, T.A., 1975, Environmental tritium in the Edwards aquifer, central Texas, 1963-71: U.S. Geological Survey Open-File Report 74-362, $32 \mathrm{p}$.

Perez, Roberto, 1986, Potential for updip movement of saline water in the Edwards aquifer, San Antonio, Texas: U.S. Geological Survey Water-Resources Investigations Report 86-4032, $21 \mathrm{p}$.

Petitt, B.M., Jr., and George, W.O., 1956, Ground-water resources of the San Antonio area, Texas: Texas Board of Water Engineers Bulletin 5608, 2 v.

Plummer, L.N., and Wigley, T.M.L., 1976, The dissolution of calcite in $\mathrm{CO}_{2}$-saturated solutions at $25^{\circ} \mathrm{C}$ and 1 atmosphere total pressure: Geochimica et Cosmochimica Acta, v. 40, p. 191-202.

Puente, Celso, 1976, Statistical analysis of water-level, springflow, and streamflow data for the Edwards aquifer in southcentral Texas: U.S. Geological Survey Open-File Report 76-393, $58 \mathrm{p}$.

Puente, Celso, 1978, Method of estimating natural recharge to the Edwards aquifer in the San Antonio area, Texas: U.S. Geological Survey Water-Resources Investigations Report 78-10, $34 \mathrm{p}$.

Quinlan, J.F., Ewers, R.O., and Palmer, A.N., 1986, Hydrogeology of Turnhole Spring groundwater basin, Kentucky, in Centennial field guide: Southeastern Section of the Geological Society of America, v. 6, p. 7-12.

Rettman, P.L., 1991, World's largest flowing well, in Twichell Hydrology Symposium, Austin, Tex., November 8, 1991, Proceedings: Austin, American Water Resources Association, Texas State Section, p. 64.

Rose, P.R., 1972, Edwards Group, surface and subsurface, central Texas: Austin, University of Texas, Bureau of Economic Geology Report of Investigations 74, 198 p.

Rothermel, S.R., and Ogden, A.E., 1986, Hydrochemical investigation of the Comal and Hueco Spring systems, Comal County, Texas: San Marcos, Edwards Aquifer Research and Data Center Report R2-86, 151 p. 
Rothermel, S.R., Ogden, A.E., and Snider, C.C., 1987, Hydrochemical investigation of the Comal and Hueco Spring systems, Comal County, Texas: San Marcos, Edwards Aquifer Research and Data Center Report R1-87, 182 p.

Rye, R.O., Back, W., Hanshaw, B.B., Rightmire, C.T., and Pearson, F.J., Jr., 1981, Origin and isotopic composition of dissolved sulfide in groundwater from carbonate aquifers in Florida and Texas: Geochimica et Cosmochimica Acta, v. 45, no. 10 , p. $1,941-1,950$.

San Antonio Water System, 2000, Water statistics, year ending December 31, 2000: System Development Department, San Antonio Water System [variously paged].

Sayre, A.N., and Bennett, R.R., 1942, Recharge, movement and discharge in the Edwards Limestone reservoir, Texas: Transactions of American Geophysical Union, pt. 1, p. 19-27.

Scanlon, B.R., Mace, R.E., Barrett, M.E., and Smith, B., 2003, Can we simulate regional groundwater flow in a karst system using equivalent porous media models? Case study, Barton Springs Edwards, USA: Journal of Hydrology, v. 276, p. 137-158.

Scanlon, B.R., Mace, R.E., Smith, Brian, Hovorka, S.D., Dutton, A.R., and Reedy, R.C., 2002, Groundwater availability of the Barton Springs segment of the Edwards aquifer, Texas-Numerical simulations through 2050: Austin, University of Texas, Bureau of Economic Geology, final report prepared for Lower Colorado River Authority under contract no. UTA99-0, $36 \mathrm{p}$.

Schindel, G.M., Johnson, S.B., Worthington, S.R.H., Alexander, E.C., Jr., Alexander, Scott, and Schnitz, Lewis, 2002, Groundwater flow velocities for the deep artesian portion of the Edwards aquifer, near Comal Springs, Texas, in Annual Meeting of the Geological Society of America, Denver, Colo., October 27-30, 2002: Geological Society of America Abstracts with Programs, v. 34, no. 6, p. 347.

Schultz, A.L., 1992, Using geophysical logs in the Edwards aquifer to estimate water quality along the freshwater/salinewater interface (Uvalde to San Antonio, Texas): San Antonio, Edwards Underground Water District Report 92-03, $47 \mathrm{p}$.

Schultz, A.L., 1993, Defining the Edwards aquifer freshwater/ saline-water interface with geophysical logs and measured data (San Antonio to Kyle, Texas): San Antonio, Edwards Underground Water District Report 93-06, 81 p.

Schultz, A.L., 1994, 1994 review and update of the position of the Edwards aquifer freshwater/saline-water interface from Uvalde to Kyle, Texas: San Antonio, Edwards Underground Water District report 94-05, 31 p.

Senger, R.K., and Kreitler, C.W., 1984, Hydrogeology of the Edwards aquifer, Austin area, Central Texas: Austin, University of Texas, Bureau of Economic Geology Report of Investigations $141,35 \mathrm{p}$.

Shuster, E.T., and White, W.B., 1971, Seasonal fluctuations in the chemistry of limestone springs-A possible means for characterizing carbonate aquifers: Journal of Hydrology, v. 14 , p. $93-128$
Sieh, T.H., 1975, Edwards (Balcones fault zone) aquifer test well drilling investigation: Texas Water Development Board Report, $117 \mathrm{p}$.

Slade, R.M., Jr., Dorsey, M.E., and Stewart, S.L., 1986, Hydrology and water quality of the Edwards aquifer associated with Barton Springs in the Austin area, Texas: U.S. Geological Survey Water-Resources Investigations Report 86-4036, $96 \mathrm{p}$.

Slade, R.M., Jr., Ruiz, Linda, and Slagle, Diana, 1985, Simulation of the flow system of Barton Springs and associated Edwards aquifer in the Austin area, Texas: U.S. Geological Survey Water-Resources Investigations Report 85-4299, $49 \mathrm{p}$.

Slattery, R.N., 2004, Recharge to the Edwards aquifer in the San Antonio area, Texas, 2003: accessed July 12, 2004, at URL http://tx.usgs.gov/reports/dist/dist-2004-01

Small, T.A., 1986, Hydrogeologic sections of the Edwards aquifer and its confining units in the San Antonio area, Texas: U.S. Geological Survey Water-Resources Investigations Report 85-4259, 52 p.

Small, T.A., and Hanson, J.A., 1994, Geologic framework and hydrogeologic characteristics of the Edwards aquifer outcrop, Comal County, Texas: U.S. Geological Survey WaterResources Investigations 94-4117, $10 \mathrm{p}$.

Small, T.A., Hanson, J.A., and Hauwert, N.M., 1996, Geologic framework and hydrogeologic characteristics of the Edwards aquifer outcrop (Barton Springs segment), northeastern Hays and southwestern Travis Counties, Texas: U.S. Geological Survey Water-Resources Investigations Report 96-4306, $15 \mathrm{p}$.

Small, T.A., and Maclay, R.W., 1982, Test-hole data for the Edwards aquifer in the San Antonio area, Texas: Texas Department of Water Resources LP-171, 153 p.

Stein, W.G., 1993, Population and well distribution for the Edwards aquifer, in Kuniansky, E.L., ed., Man's effect on hydrologic systems-Fall meeting, Texas Section, Austin, Tex., December 10, 1993, Proceedings: American Water Resources Association, p. 17-22.

Stein, W.G., and Ozuna, G.B., 1995, Geologic framework and hydrogeologic characteristics of the Edwards aquifer recharge zone, Bexar County, Texas: U.S. Geological Survey Water-Resources Investigations 95-4030, 8 p.

Technical Advisory Panel, 1990, Technical factors in Edwards aquifer use and management: Special committee on the Edwards Aquifer, Committee Report to the 72d Texas Legislature, $57 \mathrm{p}$.

Texas Water Development Board, 1996, Surveys of irrigation in Texas 1958, 1964, 1969, 1974, 1979, 1984, 1989, and 1994: Texas Water Development Board Report 347, 59 p.

Texas Water Development Board, 1997, Water for Texas1997 State plan: Texas Water Development Board [variously paged]. 
Texas Water Development Board, 2003, Well information/ ground water data: accessed periodically, January-August 2003, at URL

http://www.twdb.state.tx.us/data/waterwell/well_info.asp

Texas Water Development Board, 2004, GAM documents: accessed, August 19, 2004, at URL

http://www.twdb.state.tx.us/gam/GAM_documents/ documents.htm

Thorkildsen, D.F., and McElhaney, P.D., 1992, Model refinement and applications for the Edwards (Balcones fault zone) aquifer in the San Antonio region, Texas: Texas Water Development Board Report 340, 33 p.

Thrailkill, J., 1968, Chemical and hydrologic factors in the excavation of limestone caves: Geological Society of America Bulletin 79, p. 19-46.

Tomasko, David, Fisher, Ann-Marie, Williams, G.P., and Pentecost, E.D., 2001, A statistical study of the hydrologic characteristics of the Edwards aquifer: Chicago, Argonne National Laboratory, $38 \mathrm{p}$.

U.S. Army Corps of Engineers, 1965, Survey report on Edwards underground reservoir, Guadalupe, San Antonio, and Nueces Rivers and tributaries, Texas: U.S. Army Corps of Engineers, Fort Worth District and Texas, Edwards Underground Water District, $2 \mathrm{v}$.

U.S. Environmental Protection Agency, 2003, Sole source aquifer protection program-National summary of sole source aquifer designations: accessed July 22, 2004, at URL http://www.epa.gov/safewater/swp/sumssa.html

Vauter, B.K., 1992, Geology and its influence on cavern development in an area surrounding Natural Bridge Caverns, Comal County, Texas: Geological Society of America Abstracts with Programs, v. 24, no. 1, p. 49.

Veni, George, 1988, The caves of Bexar County (2d ed.): Austin, University of Texas, Texas Memorial Museum Speleological Monograph 2, $300 \mathrm{p}$.

Veni, George, 1994, Geomorphology, hydrogeology, geochemistry, and evolution of the karstic lower Glen Rose aquifer, south-central Texas: University Park, Pa., Pennsylvania State University, Ph.D. dissertation, 749 p.

Veni, George, 1995, Revisiting the boundaries of the Edwards (Balcones fault zone) aquifer recharge zone, in Jordan, W., and Jensen, R., eds., 24th Water for Texas Conference, College Station, Tex., January 26-27, 1995, Proceedings: Texas Water Resources Institute, p. 99-107.

Walker, L.E., 1979, Occurrence, availability, and chemical quality of ground water in the Edwards Plateau region of Texas: Texas Department of Water Resources Report 235, $346 \mathrm{p}$.

Wanakule, Nisai, and Anaya, Roberto, 1993, A lumped parameter model for the Edwards aquifer: Texas A\&M University, Texas Water Resources Institute Technical Report 163, 84 p.

Watterreus, P.A., 1992, Hydrogeology of the Camp Bullis area, northern Bexar County, Texas: San Antonio, University of Texas, Masters Thesis, $186 \mathrm{p}$.
Waugh, J.R., 1993, South Medina County observation well project: San Antonio, Edwards Underground Water District Report 93-11, $10 \mathrm{p}$.

Welder, F.A., and Reeves, R.D., 1962, Geology and groundwater resources of Uvalde County, Texas: Texas Water Commission Bulletin 6212, 252 p.

Wermund, E.G., Cepeda, J.C., and Luttrell, P.E., 1978, Regional distribution of fractures in the southern Edwards Plateau and their relationship to tectonics and caves: Austin, University of Texas, Bureau of Economic Geology Geological Circular 78-2, 14 p.

White, W.B., and White, E.L., 1989, Karst hydrologyConcepts from the Mammoth Cave area: New York, Van Nostrand Reinhold, 346 p.

William F. Guyton and Associates, 1955, The Edwards Limestone reservoir: Consultant report to City Water Board, San Antonio, Tex., $30 \mathrm{p}$.

William F. Guyton and Associates, 1979, Geohydrology of Comal, San Marcos, and Hueco springs: Texas Department of Water Resources Report 234, 85 p.

Woodbury, A.D., and Ulrych, T.J., 1998, Minimum relative entropy and probabilistic inversion in groundwater hydrology: Stochastic Hydrology and Hydraulics, v. 12, p. 317358.

Woodbury, A.D., and Ulrych, T.J., 2000, A full-Bayesian approach to the groundwater inverse problem for steady state flow: Water Resources Research, v. 36, no. 8, p. 2,0812,093 .

Woodruff, C.M., Jr., and Abbott, P.L., 1979, Cavern development, stream piracy and aquifer evolution in the Edwards Limestone [abs.]: National Speleological Society Bulletin, v. 41 , no. 4 , p. 117.

Woodruff, C.M., Jr., and Abbott, P.L., 1986, Stream piracy and evolution of the Edwards aquifer along the Balcones Escarpment, Central Texas, in Abbot, P.L., and Woodruff, C.M., Jr. eds., The Balcones escarpment—geology, hydrology, ecology and social development in central Texas: Geological Society of America, p. 77-100.

Worthington, S.R.H., 1999, A comprehensive strategy for understanding flow in carbonate aquifers, in Palmer, A.N., Palmer, M.V., and Sasowsky, I.D., eds. Karst modeling: Karst Waters Institute, Special Publication 5, p. 30-37.

Worthington, S.R.H., 2001, Depth of conduit flow in unconfined carbonate aquifers: Geology, v. 29, p. 335-338.

Worthington, S.R.H., 2004, Conduits and turbulent flow in the Edwards aquifer: Worthington Groundwater, contract report to Edwards Aquifer Authority, San Antonio, Tex., 41 p.

Worthington, S.R.H., Davies, G.J., and Ford, D.C., 2000, Matrix, fracture and channel components of storage and flow in a Paleozoic limestone aquifer, in Wicks, C., and Sasowsky, I., eds., Groundwater flow and contaminant transport in carbonate aquifers: Brookfield, Vt., A.A. Balkema, p. 113-128. 
Worthington, S.R.H., and Ford, D.C., 1997, Borehole tests for megascale channeling in carbonate aquifers, in Sixth Conference on Limestone Hydrology and Fissured Media, La Chaux-de-Fonds, Switzerland, August 10-17, 1997, Proceedings: Centre of Hydrogeology, Neuchâtel University, Switzerland, p. 191-195.

Worthington, S.R.H., Ford, D.C., and Beddows, P.A., 2000, Porosity and permeability enhancement in unconfined carbonate aquifers as a result of solution, in Klimchouk, A.,
Ford, D.C., Palmer, A.N., and Dreybrodt, W., eds., Speleogenesis-Evolution of karst aquifers: Huntsville, Ala., National Speleological Society, p. 463-472.

Worthington, S.R.H., Schindel, G.M., and Alexander, E.C., Jr., 2002, Techniques for investigating the extent of karstification in the Edwards aquifer, Texas, in Martin, J.B., Wicks, C.M., Sasowsky, I.D., eds., Hydrogeology and biology of post-Paleozoic carbonate aquifers: Karst Waters Institute, Special Publication 7, p. 173-175. 
Table 3. Estimated recharge rates, by subzone of the recharge zone, Edwards aquifer model, San Antonio region, Texas, 1939-2000.

[Monthly recharge rates have been estimated by the U.S. Geological Survey for the San Antonio segment of the Edwards aquifer since 1934. Monthly recharge rates for the Barton Springs segment of the Edwards aquifer were estimated by Barrett and Charbeneau (1996) and Scanlon and others (2002) for the period 1979-98. Monthly recharge rates for 1947-78 and 1999-2000 were estimated using the methods described by Barrett and Charbeneau (1996) and Scanlon and others (2002). The Barton Springs 'segment other than Onion Creek includes the Little Bear Creek, Bear Creek, Slaughter Creek, Williamson Creek, and Barton Creek recharge basins. NM, no estimates available; NA, not applicable; acre-ft/yr, acre-feet per year; acre-ft/mo, acre-feet per month]

\begin{tabular}{|c|c|c|c|c|c|c|c|c|c|c|}
\hline \multirow{4}{*}{ Year } & \multicolumn{10}{|c|}{$\begin{array}{c}\text { Estimated recharge rate } \\
\text { (acre-ft/yr) }\end{array}$} \\
\hline & \multicolumn{8}{|c|}{ Recharge subzone } & \multicolumn{2}{|c|}{ Barton Springs segment } \\
\hline & \multicolumn{8}{|c|}{ San Antonio segment } & \multirow[b]{2}{*}{$\begin{array}{l}\text { Onion } \\
\text { Creek }\end{array}$} & \multirow[b]{2}{*}{$\begin{array}{c}\text { Barton Spring } \\
\text { segment } \\
\text { other than } \\
\text { Onion Creek }\end{array}$} \\
\hline & $\begin{array}{l}\text { Nueces-West } \\
\text { Nueces } \\
\text { River }\end{array}$ & $\begin{array}{l}\text { Frio-Dry } \\
\text { Frio River }\end{array}$ & $\begin{array}{c}\text { Sabinal } \\
\text { River }\end{array}$ & $\begin{array}{l}\text { Area between } \\
\text { Sabinal and } \\
\text { Medina River }\end{array}$ & $\begin{array}{l}\text { Medina } \\
\text { River }\end{array}$ & $\begin{array}{c}\text { Area between } \\
\text { Medina River } \\
\text { and Cibolo- } \\
\text { Dry Comal Creek }\end{array}$ & $\begin{array}{c}\text { Cibolo-Dry } \\
\text { Comal } \\
\text { Creek }\end{array}$ & $\begin{array}{c}\text { Blanco } \\
\text { River }\end{array}$ & & \\
\hline 1939 & 227,000 & 49,505 & 16,999 & 33,100 & 42,400 & 9,303 & 9,605 & 11,100 & NM & NM \\
\hline 1940 & 50,400 & 60,313 & 23,800 & 56,600 & 38,800 & 29,299 & 30,801 & 18,801 & $\mathrm{NM}$ & $\mathrm{NM}$ \\
\hline 1941 & 89,900 & 151,857 & 50,600 & 138,999 & 54,100 & 116,300 & 191,201 & 57,798 & NM & NM \\
\hline 1942 & 103,500 & 95,091 & 34,000 & 84,400 & 51,700 & 66,900 & 93,600 & 28,600 & $\mathrm{NM}$ & $\mathrm{NM}$ \\
\hline 1943 & 36,500 & 42,310 & 11,100 & 33,800 & 41,500 & 29,500 & 58,306 & 20,099 & NM & $\mathrm{NM}$ \\
\hline 1944 & 64,109 & 75,967 & 24,800 & 74,303 & 50,500 & 72,500 & 152,498 & 46,201 & $\mathrm{NM}$ & $\mathrm{NM}$ \\
\hline 1945 & 47,300 & 71,086 & 30,800 & 78,602 & 54,800 & 79,599 & 129,901 & 35,701 & NM & $\mathrm{NM}$ \\
\hline 1946 & 80,900 & 54,215 & 16,500 & 51,999 & 51,400 & 105,100 & 155,301 & 40,699 & $\mathrm{NM}$ & NM \\
\hline $\begin{array}{l}\text { Average } \\
1939-46\end{array}$ & 87,451 & 75,043 & 26,075 & 68,975 & 48,150 & 63,563 & 102,652 & 32,375 & NA & NA \\
\hline
\end{tabular}

\begin{tabular}{|c|c|c|c|c|c|c|c|c|c|c|}
\hline \multirow{4}{*}{ Month and year } & \multicolumn{10}{|c|}{$\begin{array}{c}\text { Estimated recharge rate } \\
\text { (acre-ft/mo) }\end{array}$} \\
\hline & \multicolumn{8}{|c|}{ Recharge subzone } & \multicolumn{2}{|c|}{ Barton Springs segment } \\
\hline & \multicolumn{8}{|c|}{ San Antonio segment } & \multirow[b]{2}{*}{$\begin{array}{l}\text { Onion } \\
\text { Creek }\end{array}$} & \multirow[b]{2}{*}{$\begin{array}{c}\text { Barton Springs } \\
\text { segment } \\
\text { other than } \\
\text { Onion Creek }\end{array}$} \\
\hline & $\begin{array}{l}\text { Nueces-West } \\
\text { Nueces } \\
\text { River }\end{array}$ & $\begin{array}{l}\text { Frio-Dry } \\
\text { Frio River }\end{array}$ & $\begin{array}{l}\text { Sabinal } \\
\text { River }\end{array}$ & $\begin{array}{c}\text { Area between } \\
\text { Sabinal and } \\
\text { Medina River }\end{array}$ & $\begin{array}{l}\text { Medina } \\
\text { River }\end{array}$ & $\begin{array}{c}\text { Area between } \\
\text { Medina River } \\
\text { and Cibolo- } \\
\text { Dry Comal Creek }\end{array}$ & $\begin{array}{c}\text { Cibolo-Dry } \\
\text { Comal } \\
\text { Creek }\end{array}$ & $\begin{array}{c}\text { Blanco } \\
\text { River }\end{array}$ & & \\
\hline January 1947 & 10,400 & 9,227 & 2,100 & 10,390 & 5,300 & 19,365 & 26,054 & 10,220 & 2,324 & 2,841 \\
\hline February 1947 & 5,600 & 8,065 & 2,000 & 7,490 & 5,400 & 10,494 & 15,665 & 3,720 & 2,178 & 2,662 \\
\hline March 1947 & 6,900 & 7,458 & 1,800 & 5,690 & 5,500 & 8,439 & 12,231 & 3,880 & 2,615 & 3,196 \\
\hline April 1947 & 6,000 & 7,212 & 1,600 & 3,630 & 3,300 & 6,058 & 8,210 & 1,350 & 2,671 & 3,265 \\
\hline May 1947 & 8,500 & 8,675 & 1,800 & 4,830 & 3,300 & 4,868 & 6,032 & 0 & 2,382 & 2,912 \\
\hline June 1947 & 13,000 & 10,987 & 4,400 & 5,800 & 3,400 & 1,082 & 2,011 & 400 & 1,968 & 2,405 \\
\hline July 1947 & 5,900 & 9,340 & 1,600 & 2,660 & 3,400 & 1,839 & 2,765 & 710 & 1,627 & 1,989 \\
\hline August 1947 & 7,100 & 4,685 & 700 & 1,570 & 3,200 & 865 & 2,430 & 5,150 & 1,017 & 1,243 \\
\hline September 1947 & 1,700 & 3,038 & 300 & 970 & 3,300 & 541 & 1,173 & 1,500 & 1,040 & 1,271 \\
\hline October 1947 & 1,400 & 2,486 & 100 & 360 & 2,900 & 433 & 922 & 1,110 & 1,395 & 1,704 \\
\hline November 1947 & 4,300 & 2,886 & 100 & 480 & 2,700 & 649 & 838 & 1,980 & 815 & 997 \\
\hline December 1947 & 1,600 & 3,611 & 200 & 1,330 & 2,300 & 865 & 1,173 & 1,580 & 784 & 959 \\
\hline January 1948 & 1,400 & 3,255 & 2,889 & 350 & 1,900 & 1,591 & 1,731 & 1,680 & 755 & 923 \\
\hline February 1948 & 3,700 & 3,195 & 3,852 & 930 & 500 & 909 & 1,010 & 800 & 630 & 770 \\
\hline March 1948 & 1,500 & 3,195 & 6,741 & 810 & 300 & 909 & 1,154 & 580 & 668 & 817 \\
\hline April 1948 & 4,500 & 2,558 & 1,926 & 1,280 & 700 & 455 & 577 & 950 & 590 & 722 \\
\hline May 1948 & 4,300 & 2,194 & 963 & 1,620 & 900 & 455 & 1,875 & 1,970 & 581 & 710 \\
\hline June 1948 & 4,500 & 2,370 & 1,926 & 6,500 & 4,000 & 7,727 & 7,210 & 1,090 & 534 & 653 \\
\hline July 1948 & 12,400 & 2,174 & 963 & 1,160 & 900 & 1,591 & 2,452 & 1,020 & 726 & 888 \\
\hline August 1948 & 1,100 & 1,007 & 0 & 0 & 400 & 909 & 577 & 1,390 & 552 & 675 \\
\hline September 1948 & 3,800 & 997 & 2,889 & 1,510 & 100 & 455 & 433 & 1,240 & 647 & 790 \\
\hline October 1948 & 2,100 & 1,426 & 2,889 & 3,370 & 2,300 & 1,136 & 1,298 & 360 & 784 & 959 \\
\hline November 1948 & 900 & 1,466 & 0 & 1,740 & 2,500 & 455 & 721 & 1,240 & 534 & 653 \\
\hline December 1948 & 900 & 1,769 & 963 & 930 & 300 & 909 & 865 & 880 & 552 & 675 \\
\hline January 1949 & 5,200 & 2,370 & 300 & 2,780 & 2,600 & 984 & 1,331 & 0 & 581 & 710 \\
\hline February 1949 & 50,700 & 10,609 & 5,200 & 11,100 & 3,100 & 1,967 & 2,071 & 0 & 525 & 641 \\
\hline March 1949 & 12,400 & 15,328 & 4,000 & 8,440 & 3,500 & 2,951 & 6,654 & 930 & 697 & 852 \\
\hline April 1949 & 12,200 & 11,704 & 6,100 & 13,070 & 4,200 & 13,769 & 14,493 & 0 & 1,462 & 1,787 \\
\hline May 1949 & 10,100 & 10,439 & 5,200 & 10,970 & 4,900 & 11,311 & 16,119 & 6,110 & 1,307 & 1,598 \\
\hline June 1949 & 9,500 & 7,558 & 2,700 & 9,020 & 5,000 & 3,688 & 5,324 & 10,140 & 1,125 & 1,375 \\
\hline July 1949 & 3,100 & 4,475 & 1,500 & 2,660 & 2,300 & 1,967 & 3,106 & 2,690 & 930 & 1,136 \\
\hline August 1949 & 25,300 & 4,411 & 1,300 & 2,200 & 1,900 & 246 & 1,183 & 2,800 & 668 & 817 \\
\hline
\end{tabular}


Table 3. Estimated recharge rates, by subzone of the recharge zone, Edwards aquifer model, San Antonio region, Texas, 1939-2000Continued.

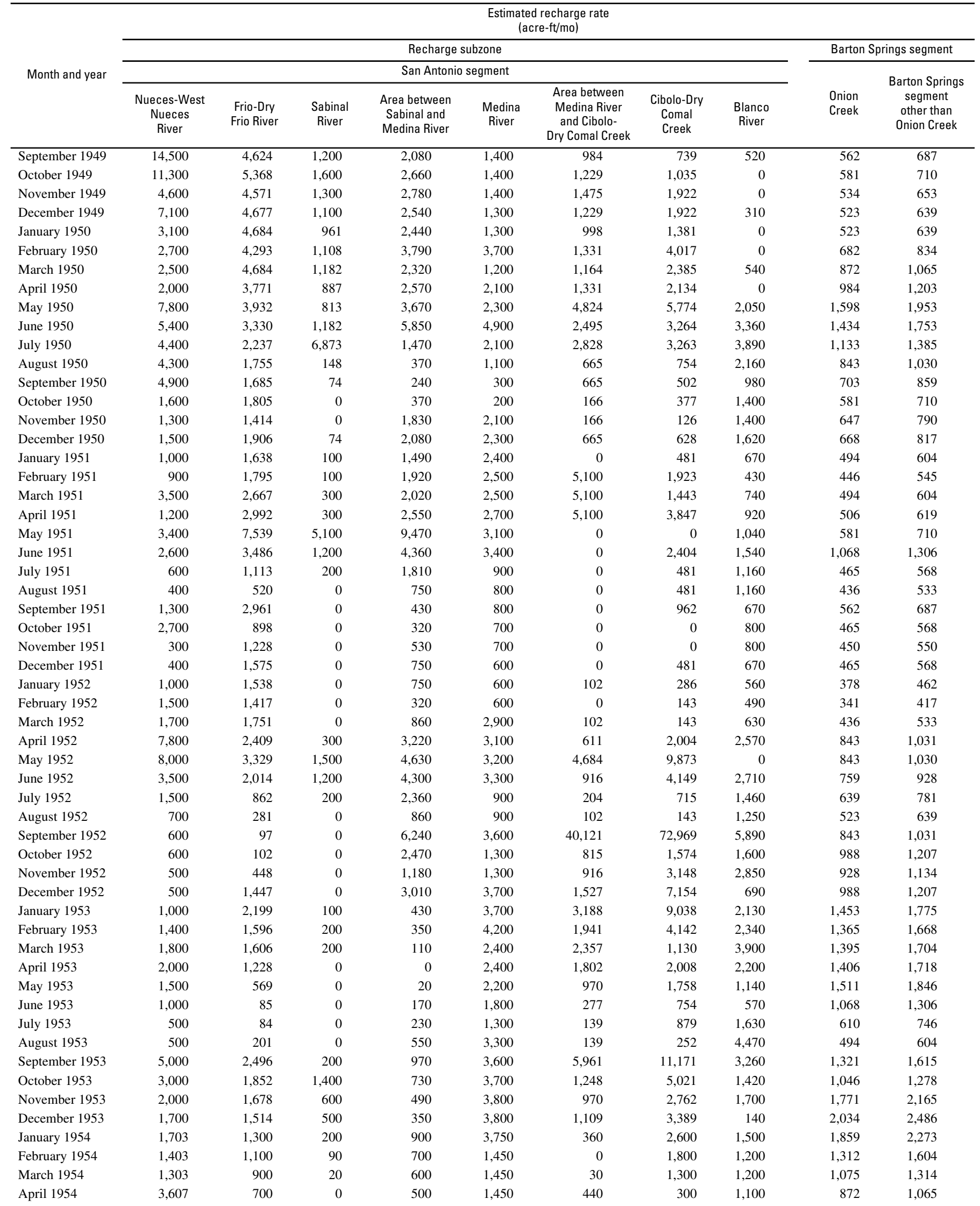


Table 3

Table 3. Estimated recharge rates, by subzone of the recharge zone, Edwards aquifer model, San Antonio region, Texas, 1939-2000— Continued.

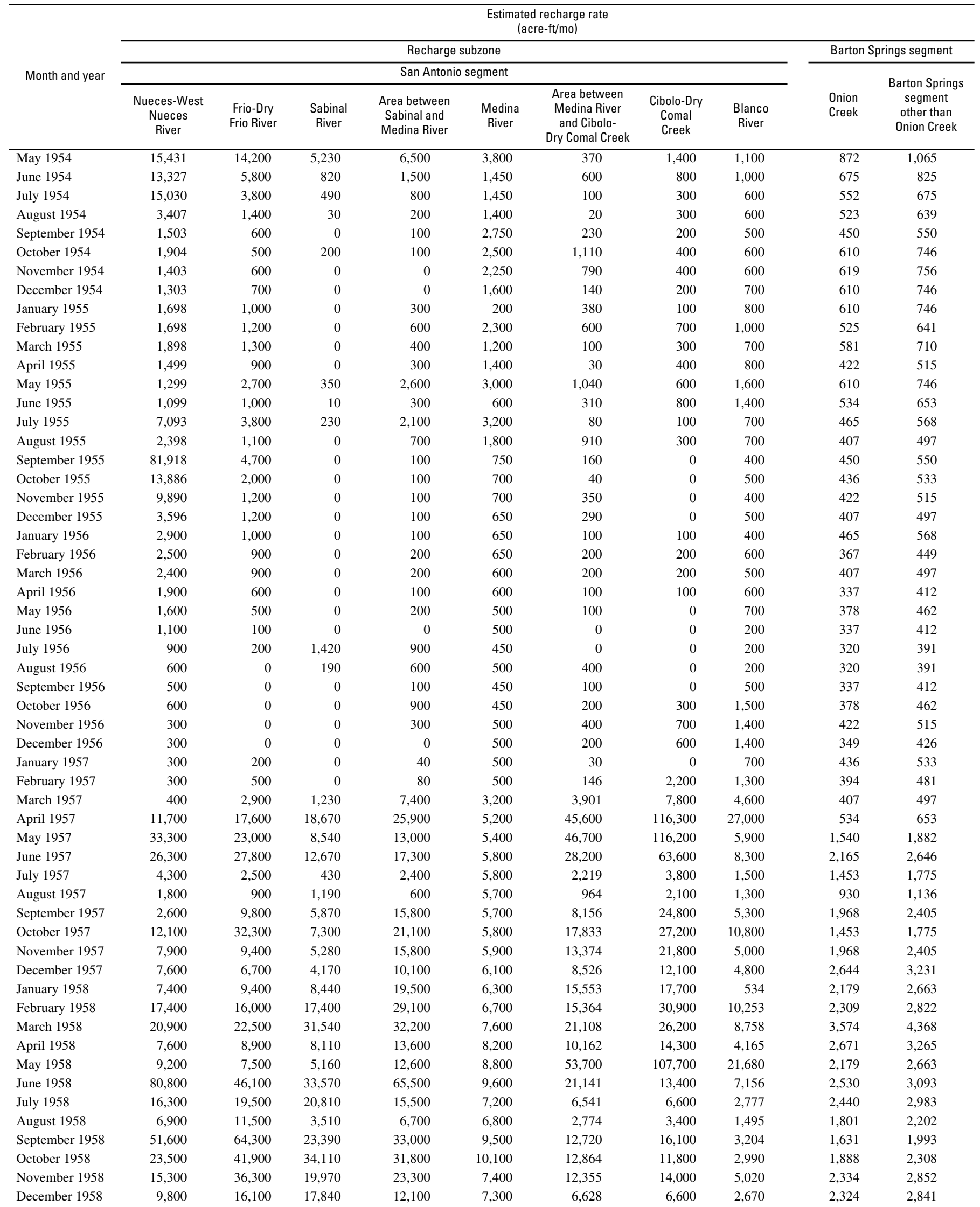


Table 3. Estimated recharge rates, by subzone of the recharge zone, Edwards aquifer model, San Antonio region, Texas, 1939-2000Continued.

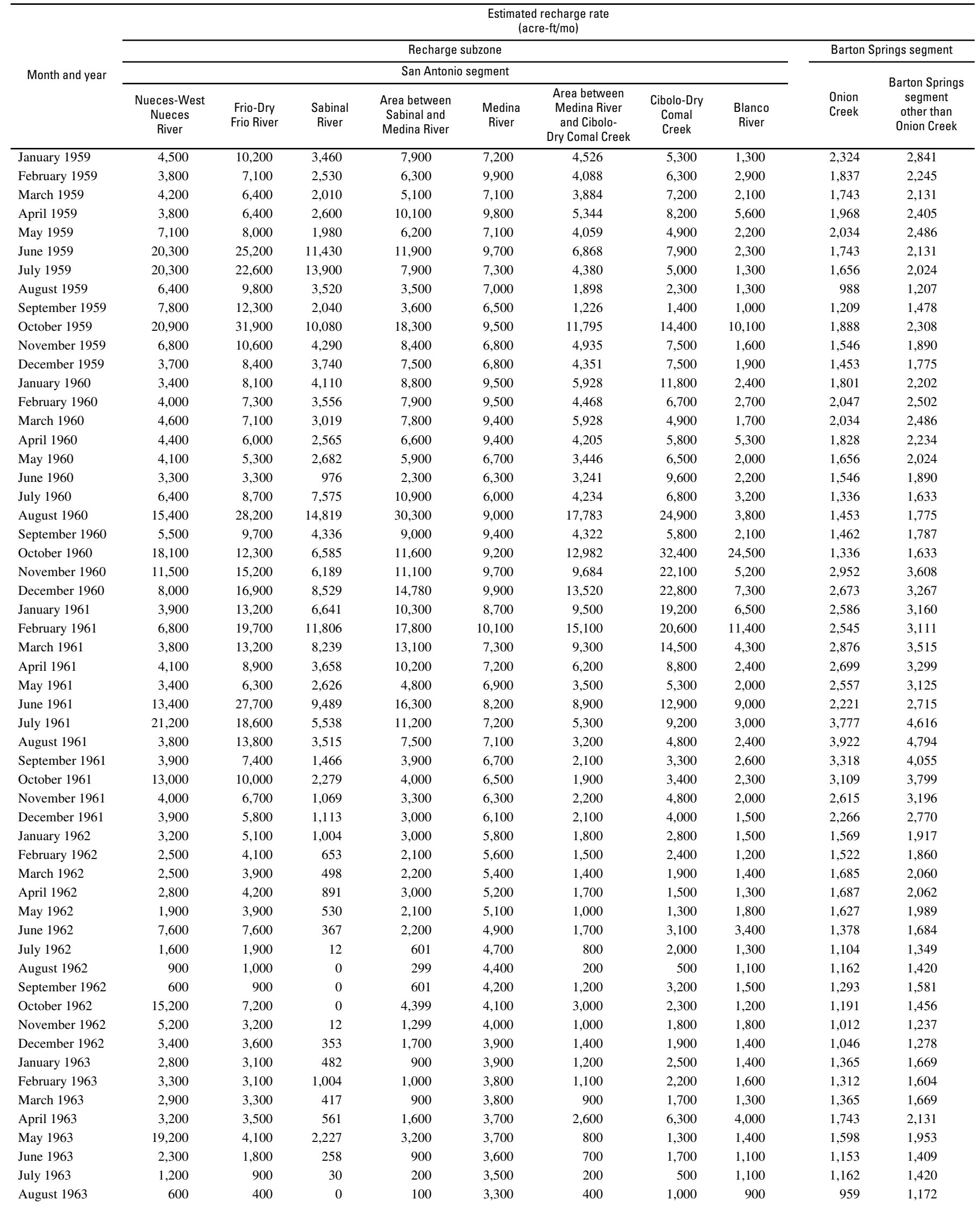


Table 3

Table 3. Estimated recharge rates, by subzone of the recharge zone, Edwards aquifer model, San Antonio region, Texas, 1939-2000— Continued.

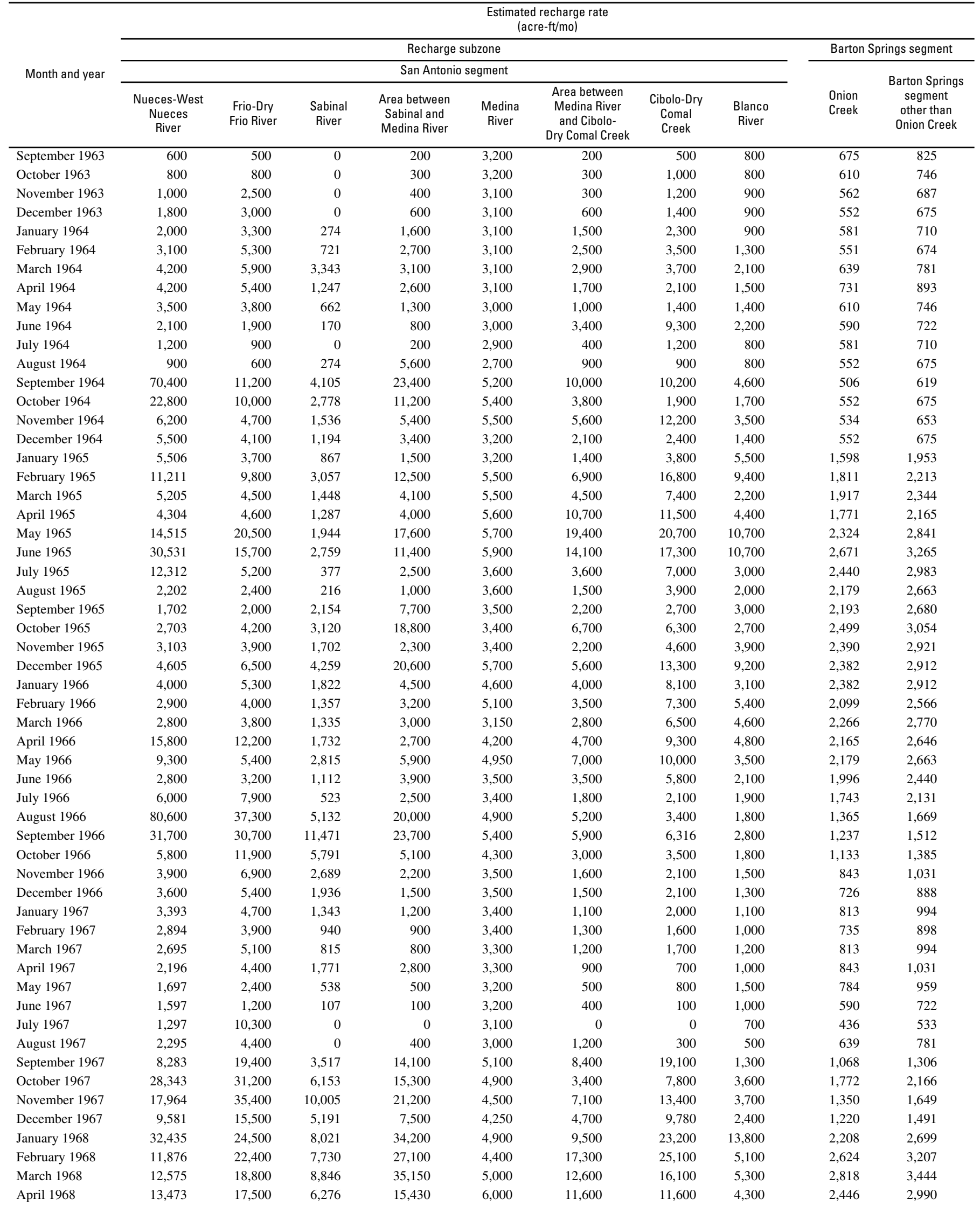


Table 3. Estimated recharge rates, by subzone of the recharge zone, Edwards aquifer model, San Antonio region, Texas, 1939-2000Continued.

\begin{tabular}{|c|c|c|c|c|c|c|c|c|c|c|}
\hline \multirow{3}{*}{ Month and year } & \multicolumn{10}{|c|}{$\begin{array}{l}\text { Estimated recharge rate } \\
\text { (acre-ft/mo) }\end{array}$} \\
\hline & \multicolumn{8}{|c|}{ Recharge subzone } & \multicolumn{2}{|c|}{ Barton Springs segment } \\
\hline & \multicolumn{8}{|c|}{ San Antonio segment } & $\begin{array}{l}\text { Onion } \\
\text { Creek }\end{array}$ & $\begin{array}{c}\text { Barton Springs } \\
\text { segment } \\
\text { other than } \\
\text { Onion Creek }\end{array}$ \\
\hline May 1968 & 13,972 & 29,600 & 11,824 & 30,370 & 6,300 & 16,100 & 15,300 & 3,300 & 2,586 & 3,160 \\
\hline August 1968 & 4,591 & 7,700 & 2,977 & 5,840 & 4,700 & 1,300 & 2,800 & 2,100 & 2,469 & 3,018 \\
\hline September 1968 & 3,593 & 6,100 & 3,076 & 3,790 & 3,800 & 1,000 & 3,700 & 2,200 & 2,165 & 2,646 \\
\hline October 1968 & 3,293 & 5,400 & 2,112 & 2,470 & 4,400 & 1,000 & 2,500 & 2,100 & 1,976 & 2,415 \\
\hline November 1968 & 3,892 & 4,500 & 1,519 & 1,790 & 4,300 & 400 & 1,700 & 1,900 & 1,659 & 2,027 \\
\hline December 1968 & 6,487 & 5,300 & 1,636 & 2,300 & 3,200 & 1,000 & 5,300 & 2,600 & 1,569 & 1,917 \\
\hline January 1969 & 3,888 & 4,600 & 1,482 & 1,750 & 3,900 & 1,600 & 2,800 & 1,400 & 1,453 & 1,775 \\
\hline June 1969 & 4,885 & 3,000 & 1,422 & 3,530 & 4,300 & 2,100 & 5,100 & 4,100 & 2,052 & 2,509 \\
\hline July 1969 & 1,994 & 1,600 & 272 & 1,380 & 4,100 & 1,600 & 3,300 & 2,300 & 1,947 & 2,379 \\
\hline August 1969 & 1,396 & 1,700 & 688 & 3,750 & 3,800 & 1,400 & 2,900 & 2,200 & 1,772 & 2,166 \\
\hline September 1969 & 997 & 2,700 & 486 & 2,940 & 3,500 & 2,000 & 3,700 & 1,900 & 1,574 & 1,924 \\
\hline October 1969 & 57,826 & 37,200 & 7,926 & 28,560 & 5,500 & 20,200 & 18,200 & 4,000 & 1,482 & 1,811 \\
\hline November 1969 & 10,967 & 18,700 & 5,621 & 8,780 & 5,800 & 4,700 & 3,500 & 2,000 & 1,293 & 1,581 \\
\hline December 1969 & 14,456 & 25,100 & 5,133 & 9,730 & 6,100 & 7,800 & 16,000 & 7,000 & 1,249 & 1,527 \\
\hline January 1970 & 3,804 & 10,100 & 3,245 & 5,000 & 6,500 & 5,300 & 10,699 & 1,700 & 1,365 & 1,669 \\
\hline February 1970 & 5,105 & 9,900 & 4,441 & 9,900 & 6,700 & 5,900 & 11,700 & 3,900 & 2,152 & 2,630 \\
\hline March 1970 & 12,412 & 17,900 & 9,263 & 21,100 & 6,200 & 19,900 & 24,000 & 6,100 & 3,225 & 3,942 \\
\hline April 1970 & 6,306 & 7,800 & 4,195 & 7,300 & 7,000 & 5,800 & 6,700 & 1,900 & 3,093 & 3,780 \\
\hline May 1970 & 10,010 & 19,600 & 5,084 & 14,100 & 5,700 & 12,200 & 21,400 & 13,100 & 2,992 & 3,657 \\
\hline June 1970 & 6,306 & 10,900 & 2,168 & 11,400 & 7,500 & 10,000 & 20,400 & 3,700 & 2,755 & 3,368 \\
\hline March 1971 & 7,900 & 4,400 & 600 & 520 & 4,100 & 500 & 1,000 & 1,000 & 930 & 1,136 \\
\hline April 1971 & 2,800 & 3,800 & 500 & 730 & 4,000 & 800 & 1,400 & 1,100 & 787 & 962 \\
\hline May 1971 & 2,200 & 3,200 & 200 & 610 & 3,800 & 600 & 1,400 & 1,100 & 901 & 1,101 \\
\hline June 1971 & 19,600 & 3,600 & 100 & 400 & 3,700 & 200 & 500 & 1,100 & 928 & 1,134 \\
\hline July 1971 & 13,600 & 4,100 & 30 & 250 & 3,600 & 100 & 800 & 1,000 & 581 & 710 \\
\hline August 1971 & 151,500 & 68,600 & 7,200 & 36,480 & 6,400 & 24,000 & 8,600 & 1,700 & 1,017 & 1,243 \\
\hline September 1971 & 13,700 & 19,400 & 4,700 & 20,450 & 10,000 & 10,800 & 9,800 & 1,000 & 1,884 & 2,302 \\
\hline October 1971 & 40,600 & 54,400 & 12,000 & 67,150 & 10,100 & 23,700 & 24,100 & 3,300 & 2,063 & 2,521 \\
\hline November 1971 & 1,500 & 27,200 & 7,900 & 18,480 & 7,300 & 9,800 & 13,000 & 2,500 & 2,052 & 2,509 \\
\hline December 1971 & 2,100 & 14,100 & 4,600 & 8,620 & 7,100 & 9,100 & 17,600 & 6,300 & 2,237 & 2,734 \\
\hline January 1972 & 2,600 & 9,800 & 3,700 & 5,270 & 7,200 & 6,400 & 11,300 & 2,300 & 2,905 & 3,551 \\
\hline February 1972 & 2,500 & 7,500 & 2,700 & 3,510 & 7,100 & 3,910 & 8,500 & 1,900 & 2,519 & 3,079 \\
\hline March 1972 & 3,000 & 6,600 & 2,300 & 2,700 & 7,000 & 2,400 & 7,500 & 2,300 & 2,615 & 3,196 \\
\hline April 1972 & 3,200 & 5,000 & 1,500 & 5,640 & 6,600 & 2,020 & 3,300 & 1,300 & 2,418 & 2,955 \\
\hline May 1972 & 14,500 & 24,300 & 6,400 & 37,300 & 8,500 & 29,120 & 30,800 & 7,400 & 2,440 & 2,983 \\
\hline June 1972 & 4,800 & 14,200 & 3,500 & 12,810 & 7,300 & 8,850 & 9,700 & 2,700 & 2,474 & 3,024 \\
\hline July 1972 & 4,200 & 6,400 & 1,800 & 5,420 & 7,100 & 3,060 & 2,900 & 1,700 & 2,469 & 3,018 \\
\hline August 1972 & 54,200 & 25,900 & 10,900 & 47,910 & 9,800 & 5,140 & 8,700 & 3,200 & 2,353 & 2,876 \\
\hline September 1972 & 9,600 & 19,400 & 6,900 & 19,880 & 7,100 & 3,060 & 5,400 & 2,300 & 2,249 & 2,749 \\
\hline October 1972 & 3,400 & 11,300 & 4,200 & 7,010 & 7,000 & 4,360 & 6,300 & 3,400 & 2,324 & 2,841 \\
\hline November 1972 & 3,300 & 7,700 & 2,900 & 4,060 & 6,500 & 3,340 & 5,600 & 3,200 & 2,165 & 2,646 \\
\hline December 1972 & 3,100 & 6,500 & 2,200 & 3,080 & 6,700 & 2,650 & 4,200 & 1,700 & 2,150 & 2,628 \\
\hline
\end{tabular}


Table 3

Table 3. Estimated recharge rates, by subzone of the recharge zone, Edwards aquifer model, San Antonio region, Texas, 1939-2000— Continued.

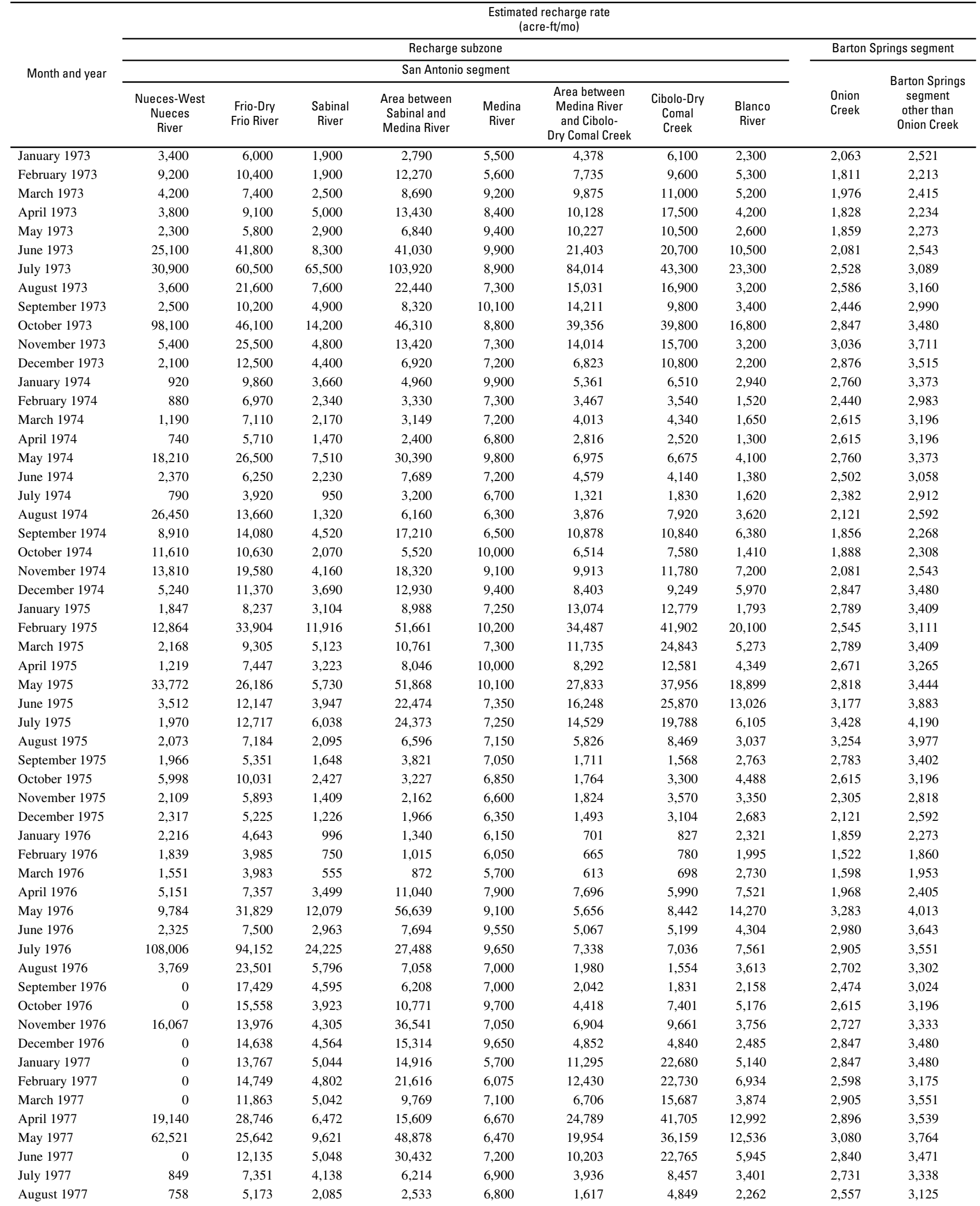


Table 3. Estimated recharge rates, by subzone of the recharge zone, Edwards aquifer model, San Antonio region, Texas, 1939-2000Continued.

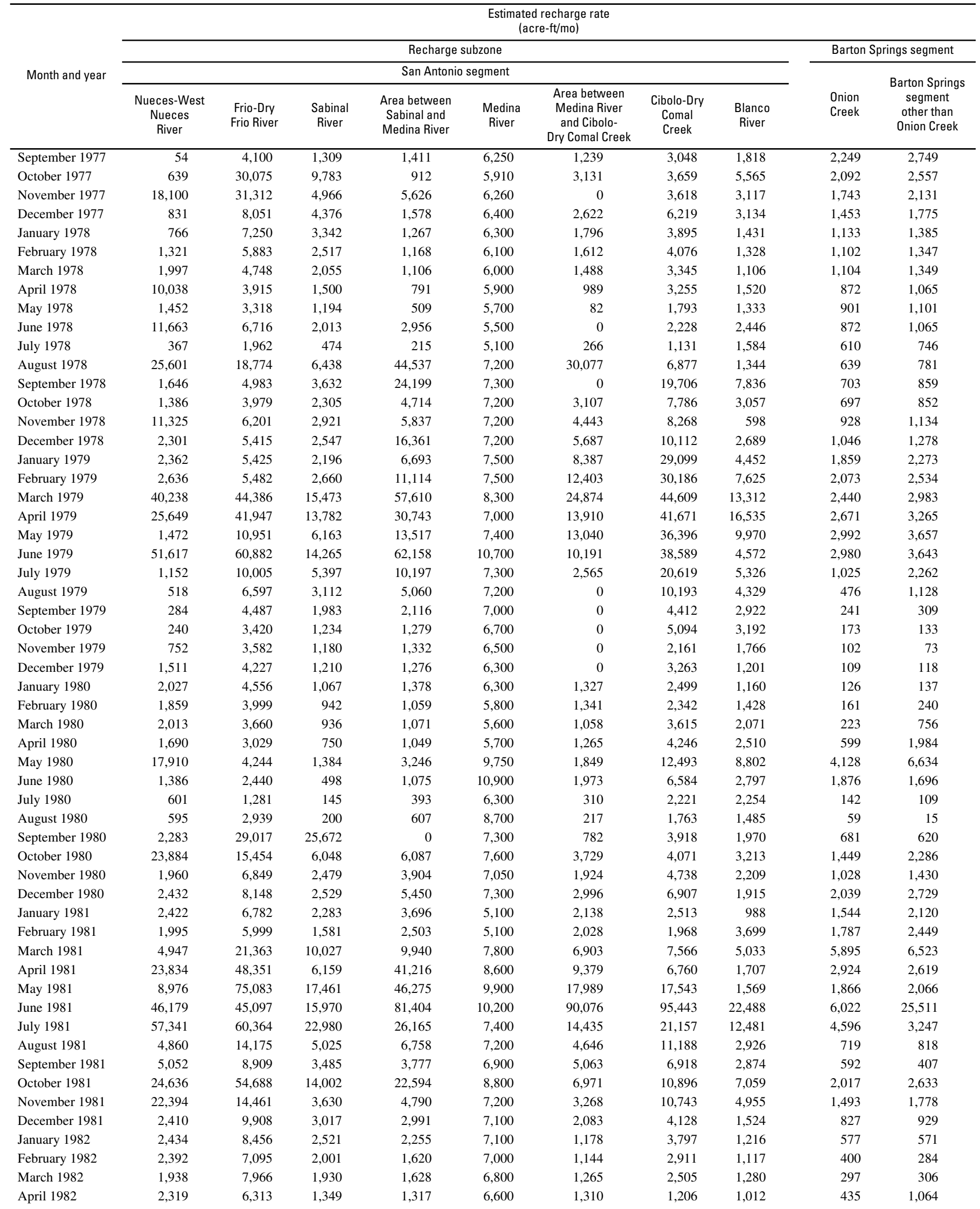


Table 3

Table 3. Estimated recharge rates, by subzone of the recharge zone, Edwards aquifer model, San Antonio region, Texas, 1939-2000— Continued.

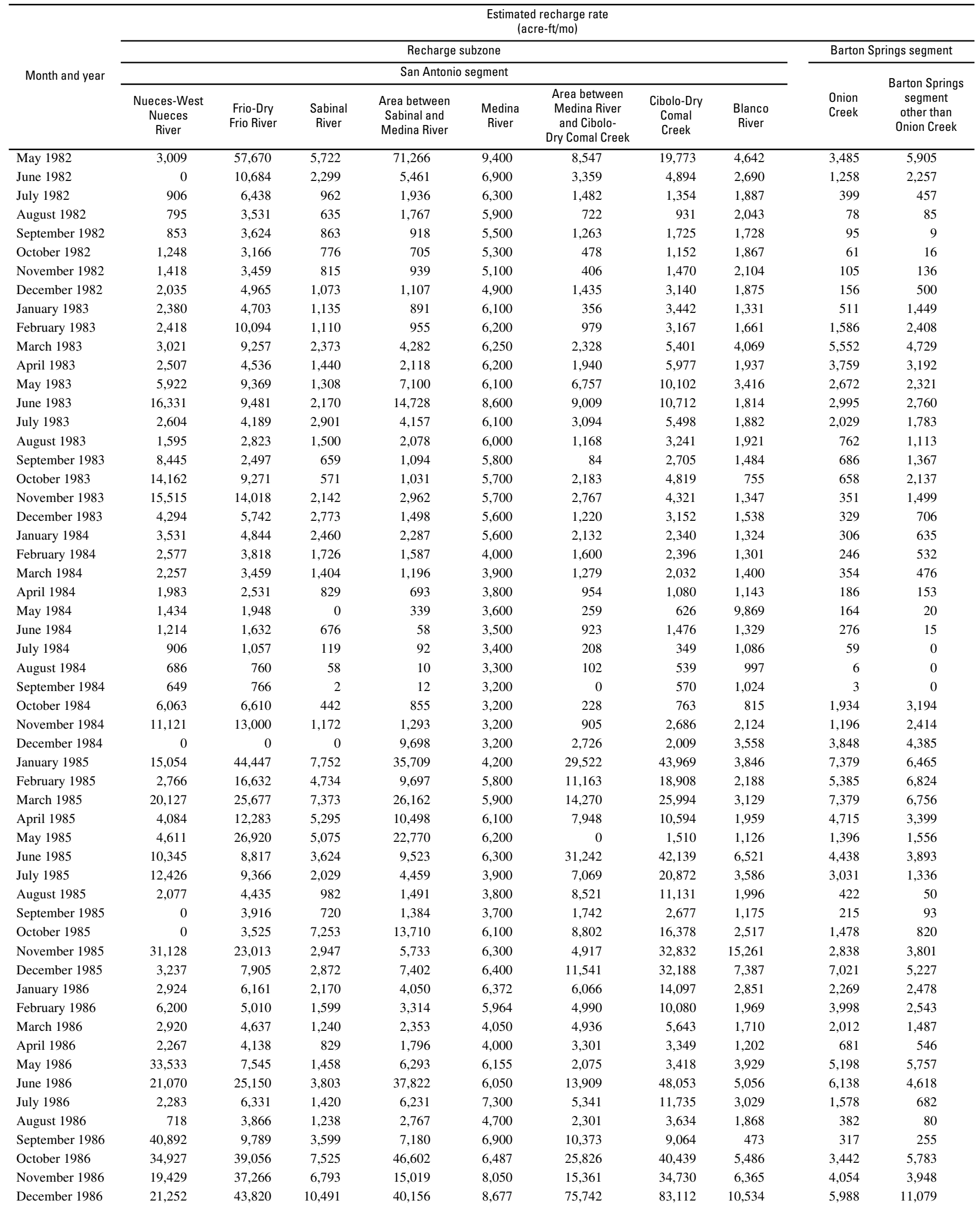


Table 3. Estimated recharge rates, by subzone of the recharge zone, Edwards aquifer model, San Antonio region, Texas, 1939-2000Continued.

\begin{tabular}{|c|c|c|c|c|c|c|c|c|c|c|}
\hline \multirow[b]{3}{*}{ Month and year } & \multicolumn{10}{|c|}{$\begin{array}{c}\text { Estimated recharge rate } \\
\text { (acre-ft/mo) }\end{array}$} \\
\hline & \multicolumn{8}{|c|}{ Recharge subzone } & \multicolumn{2}{|c|}{ Barton Springs segment } \\
\hline & \multicolumn{8}{|c|}{ San Antonio segment } & $\begin{array}{l}\text { Onion } \\
\text { Creek }\end{array}$ & $\begin{array}{c}\text { Barton Spring } \\
\text { segment } \\
\text { other than } \\
\text { Onion Creek }\end{array}$ \\
\hline January 1987 & 24,314 & 39,368 & 12,414 & 20,240 & 6,869 & 21,133 & 21,011 & 14,134 & 6,968 & 5,275 \\
\hline April 1987 & 12,448 & 12,435 & 5,068 & 9,220 & 7,350 & 8,165 & 12,624 & 2,131 & 3,519 & 2,659 \\
\hline May 1987 & 21,920 & 28,064 & 1,799 & 28,611 & 9,958 & 18,514 & 17,704 & 3,680 & 2,140 & 2,741 \\
\hline June 1987 & 203,109 & 214,158 & 48,988 & 269,800 & 7,900 & 113,128 & 82,766 & 56,232 & 7,140 & 19,501 \\
\hline July 1987 & 0 & 40,085 & 6,124 & 19,948 & 7,400 & 22,225 & 38,734 & 8,828 & 5,151 & 3,463 \\
\hline August 1987 & 0 & 21,175 & 5,570 & 7,319 & 7,300 & 8,030 & 31,058 & 6,359 & 1,355 & 1,492 \\
\hline September 1987 & 18,543 & 31,029 & 7,133 & 3,631 & 7,250 & 4,616 & 14,426 & 3,171 & 394 & 504 \\
\hline February 1988 & 524 & 6,068 & 1,547 & 1,749 & 6,550 & 1,319 & 4,098 & 1,573 & 402 & 580 \\
\hline March 1988 & 1,192 & 5,750 & 1,341 & 1,541 & 6,350 & 1,483 & 4,512 & 2,216 & 450 & 632 \\
\hline April 1988 & 1,363 & 5,489 & 883 & 1,141 & 6,150 & 1,324 & 2,808 & 1,575 & 326 & 450 \\
\hline May 1988 & 5,976 & 6,243 & 918 & 831 & 5,775 & 1,121 & 2,405 & 2,630 & 289 & 410 \\
\hline June 1988 & 17,097 & 24,795 & 1,172 & 587 & 5,450 & 0 & 3,084 & 2,783 & 178 & 227 \\
\hline July 1988 & 11,069 & 31,856 & 4,737 & 10,320 & 7,806 & 0 & 71 & 2,710 & 104 & 129 \\
\hline August 1988 & 7,046 & 8,511 & 1,824 & 1,919 & 5,625 & 2,140 & 1,649 & 3,237 & 98 & 112 \\
\hline September 1988 & 7,505 & 7,812 & 751 & 1,710 & 5,100 & 988 & 891 & 2,045 & 21 & 31 \\
\hline October 1988 & 2,720 & 4,664 & 693 & 1,053 & 5,050 & 675 & 1,145 & 1,960 & 15 & 21 \\
\hline November 1988 & 2,402 & 4,260 & 558 & 802 & 4,850 & 687 & 1,076 & 1,485 & 6 & 7 \\
\hline December 1988 & 2,339 & 4,265 & 597 & 655 & 4,650 & 727 & 1,556 & 1,301 & 6 & 8 \\
\hline January 1989 & 11,031 & 7,191 & 1,722 & 93 & 4,525 & 396 & 1,359 & 1,843 & 56 & 118 \\
\hline February 1989 & 7,485 & 8,669 & 1,870 & 1,862 & 4,392 & 1,273 & 1,755 & 1,641 & 128 & 64 \\
\hline November 1989 & 11,008 & 4,579 & 325 & 1,426 & 4,175 & 0 & 756 & 1,195 & 15 & 22 \\
\hline December 1989 & 3,193 & 3,465 & 480 & 961 & 2,648 & 683 & 1,220 & 1,234 & 19 & 15 \\
\hline January 1990 & 2,727 & 3,271 & 450 & 814 & 3,300 & 626 & 1,141 & 1,341 & 27 & 25 \\
\hline February 1990 & 16,225 & 12,764 & 881 & 2,775 & 2,982 & 119 & 245 & 1,149 & 48 & 129 \\
\hline March 1990 & 15,410 & 6,936 & 1,367 & 4,383 & 6,281 & 1,141 & 4,318 & 4,116 & 663 & 853 \\
\hline April 1990 & 79,785 & 32,519 & 3,347 & 14,950 & 6,800 & 1,715 & 4,429 & 5,097 & 991 & 1,043 \\
\hline May 1990 & 95,791 & 46,777 & 7,558 & 25,954 & 7,305 & 13,192 & 24,293 & 12,255 & 3,360 & 3,432 \\
\hline June 1990 & 4,836 & 5,455 & 1,507 & 3,244 & 3,500 & 2,473 & 5,148 & 3,317 & 1,020 & 445 \\
\hline July 1990 & 161,650 & 77,174 & 20,152 & 45,603 & 6,771 & 5,554 & 12,768 & 4,335 & 192 & 312 \\
\hline August 1990 & 78,284 & 34,914 & 7,593 & 12,343 & 3,500 & 4,580 & 7,731 & 2,852 & 96 & 59 \\
\hline September 1990 & 13,166 & 14,373 & 5,349 & 12,481 & 3,500 & 1,657 & 2,345 & 1,390 & 103 & 35 \\
\hline October 1990 & 3,991 & 8,096 & 3,072 & 5,149 & 3,450 & 1,423 & 2,305 & 1,649 & 14 & 102 \\
\hline November 1990 & 3,945 & 6,797 & 1,892 & 2,122 & 3,200 & 1,625 & 3,971 & 2,140 & 45 & 165 \\
\hline December 1990 & 3,483 & 5,962 & 1,440 & 1,404 & 3,400 & 1,829 & 3,104 & 1,642 & 42 & 72 \\
\hline January 1991 & 3,572 & 6,586 & 1,416 & 1,768 & 4,607 & 1,517 & 8,642 & 9,404 & 4,002 & 5,461 \\
\hline February 1991 & 3,285 & 7,325 & 1,246 & 1,834 & 4,571 & 4,799 & 15,902 & 11,252 & 5,234 & 5,149 \\
\hline March 1991 & 3,047 & 4,923 & 1,196 & 1,599 & 3,410 & 3,602 & 5,791 & 2,102 & 3,306 & 3,818 \\
\hline April 1991 & 7,874 & 8,818 & 1,489 & 9,825 & 3,905 & 0 & 15,526 & 21,009 & 6,444 & 7,069 \\
\hline May 1991 & 2,606 & 8,469 & 3,976 & 29,677 & 5,461 & 2,674 & 13,412 & 15,755 & 5,944 & 4,918 \\
\hline June 1991 & 7,938 & 7,447 & 4,728 & 12,947 & 3,430 & 4,499 & 6,680 & 4,473 & 2,620 & 2,640 \\
\hline July 1991 & 16,011 & 13,214 & 3,071 & 6,199 & 3,460 & 2,046 & 3,867 & 1,119 & 1,171 & 817 \\
\hline August 1991 & 2,394 & 2,537 & 1,333 & 1,685 & 3,390 & 863 & 844 & 860 & 597 & 905 \\
\hline
\end{tabular}


Table 3

Table 3. Estimated recharge rates, by subzone of the recharge zone, Edwards aquifer model, San Antonio region, Texas, 1939-2000— Continued.

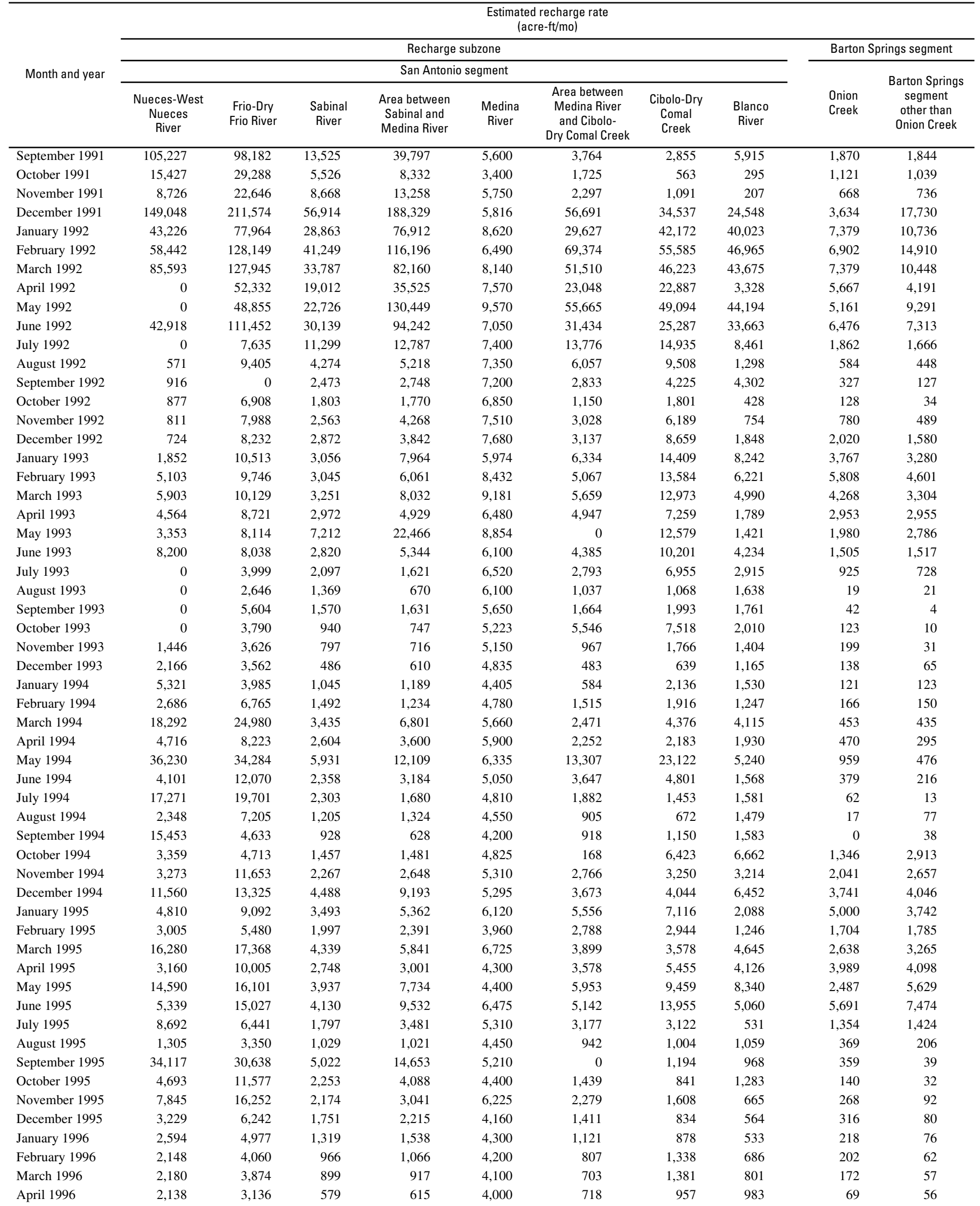


Table 3. Estimated recharge rates, by subzone of the recharge zone, Edwards aquifer model, San Antonio region, Texas, 1939-2000Continued.

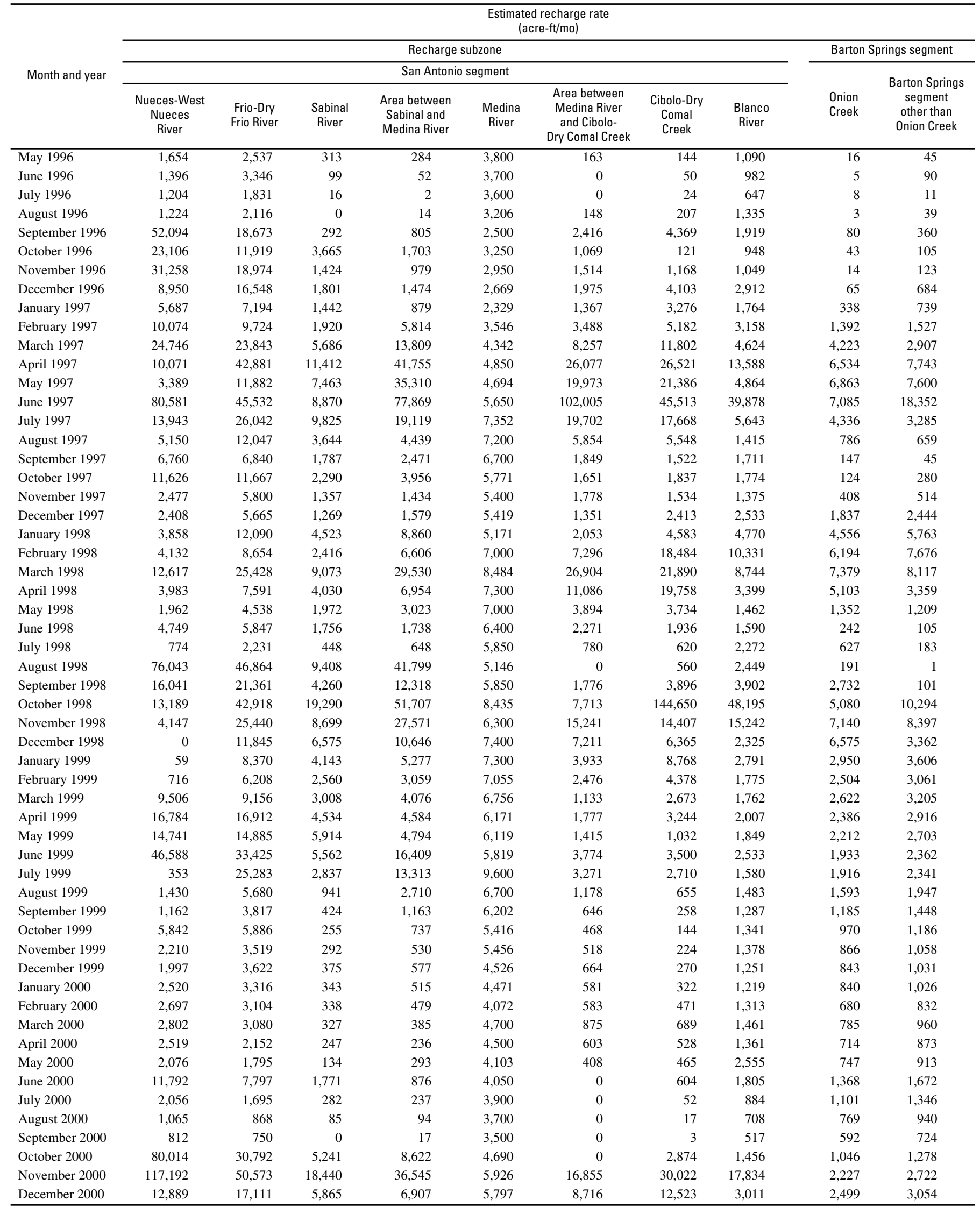


Table 4

Table 4. Ground-water withdrawals, by county, Edwards aquifer model, San Antonio region, Texas, 1939-2000.

[In acre-feet per year]

\begin{tabular}{|c|c|c|c|c|c|c|c|}
\hline \multirow{2}{*}{ Year } & \multicolumn{7}{|c|}{ County } \\
\hline & Kinney & Uvalde & Medina & Bexar & Comal & Hays & Travis \\
\hline 1939 & 28 & 3,038 & 1,600 & 116,339 & 4,200 & 389 & 582 \\
\hline 1940 & 27 & 2,932 & 1,600 & 114,153 & 3,816 & 974 & 571 \\
\hline 1941 & 27 & 2,882 & 1,600 & 171,098 & 3,332 & 2,059 & 855 \\
\hline 1942 & 30 & 3,267 & 1,700 & 176,146 & 4,858 & 1,061 & 881 \\
\hline 1943 & 37 & 4,036 & 1,700 & 157,468 & 5,091 & 597 & 787 \\
\hline 1944 & 38 & 4,045 & 1,700 & 154,054 & 3,932 & 2,333 & 770 \\
\hline 1945 & 38 & 4,120 & 1,700 & 177,359 & 4,602 & 1,171 & 887 \\
\hline 1946 & 38 & 4,145 & 1,700 & 163,426 & 4,224 & 3,170 & 817 \\
\hline Average 1939-46 & 33 & 3,558 & 1,663 & 153,755 & 4,257 & 1,469 & 769 \\
\hline 1947 & 44 & 4,786 & 2,000 & 178,077 & 3,886 & 2,100 & 792 \\
\hline 1948 & 61 & 6,571 & 1,900 & 157,847 & 2,752 & 1,718 & 804 \\
\hline 1949 & 75 & 8,101 & 2,000 & 163,198 & 1,906 & 1,979 & 831 \\
\hline 1950 & 97 & 10,408 & 2,200 & 176,027 & 2,387 & 1,946 & 839 \\
\hline 1951 & 155 & 16,714 & 2,200 & 186,738 & 3,350 & 1,079 & 850 \\
\hline 1952 & 209 & 22,491 & 3,100 & 187,100 & 2,033 & 4,670 & 865 \\
\hline 1953 & 253 & 27,247 & 4,000 & 193,700 & 3,159 & 3,149 & 888 \\
\hline 1954 & 245 & 26,355 & 6,300 & 208,900 & 3,135 & 3,832 & 911 \\
\hline 1955 & 260 & 28,040 & 11,100 & 215,200 & 4,774 & 2,877 & 940 \\
\hline 1956 & 548 & 59,052 & 17,700 & 229,600 & 10,676 & 2,962 & 972 \\
\hline 1957 & 267 & 28,733 & 11,900 & 189,357 & 7,686 & 2,725 & 970 \\
\hline 1958 & 218 & 23,482 & 6,600 & 190,469 & 4,770 & 2,462 & 984 \\
\hline 1959 & 303 & 32,602 & 8,300 & 202,877 & 4,716 & 2,453 & 1,003 \\
\hline 1960 & 290 & 31,284 & 7,600 & 201,233 & 5,511 & 2,408 & 1,010 \\
\hline 1961 & 307 & 33,042 & 6,400 & 207,779 & 7,676 & 2,532 & 1,023 \\
\hline 1962 & 442 & 47,647 & 8,100 & 215,244 & 5,262 & 2,939 & 1,038 \\
\hline 1963 & 447 & 48,136 & 9,700 & 216,644 & 5,415 & 3,193 & 1,042 \\
\hline 1964 & 453 & 48,828 & 8,600 & 200,752 & 5,086 & 3,296 & 1,028 \\
\hline 1965 & 430 & 46,304 & 10,000 & 198,674 & 5,791 & 3,279 & 1,011 \\
\hline 1966 & 441 & 47,452 & 10,400 & 196,523 & 5,903 & 4,044 & 1,014 \\
\hline 1967 & 745 & 80,266 & 15,200 & 239,466 & 8,086 & 4,652 & 1,058 \\
\hline 1968 & 462 & 49,745 & 9,900 & 195,407 & 7,650 & 4,234 & 1,034 \\
\hline 1969 & 745 & 80,240 & 13,600 & 212,094 & 7,618 & 4,272 & 1,047 \\
\hline 1970 & 785 & 84,499 & 16,500 & 224,530 & 7,614 & 5,329 & 1,061 \\
\hline 1971 & 979 & 105,418 & 32,400 & 261,051 & 9,577 & 7,272 & 1,101 \\
\hline 1972 & 864 & 93,064 & 28,800 & 240,405 & 10,209 & 7,368 & 1,104 \\
\hline 1973 & 651 & 70,086 & 14,900 & 216,319 & 10,927 & 6,094 & 1,101 \\
\hline 1974 & 968 & 104,219 & 28,600 & 233,413 & 10,874 & 7,329 & 1,126 \\
\hline 1975 & 711 & 76,521 & 22,600 & 219,319 & 10,847 & 8,519 & 1,131 \\
\hline 1976 & 950 & 102,288 & 19,400 & 213,447 & 13,545 & 11,851 & 1,115 \\
\hline 1977 & 1,026 & 110,480 & 19,900 & 236,875 & 13,614 & 10,269 & 1,147 \\
\hline 1978 & 1,212 & 130,523 & 38,700 & 246,008 & 13,671 & 11,679 & 1,168 \\
\hline 1979 & 973 & 104,787 & 32,900 & 240,521 & 14,291 & 12,068 & 1,174 \\
\hline 1980 & 1,296 & 139,598 & 39,900 & 292,209 & 16,038 & 12,212 & 1,291 \\
\hline 1981 & 805 & 86,728 & 26,100 & 258,999 & 15,664 & 10,606 & 1,485 \\
\hline 1982 & 968 & 104,199 & 33,400 & 295,422 & 15,982 & 12,026 & 1,758 \\
\hline 1983 & 856 & 92,192 & 29,700 & 276,432 & 17,212 & 12,238 & 2,089 \\
\hline 1984 & 1,418 & 152,668 & 46,900 & 309,560 & 19,546 & 13,584 & 2,494 \\
\hline 1985 & 1,368 & 147,335 & 59,200 & 292,977 & 19,022 & 12,874 & 2,871 \\
\hline 1986 & 691 & 74,396 & 41,900 & 284,160 & 21,287 & 14,920 & 3,085 \\
\hline 1987 & 402 & 43,318 & 15,900 & 261,667 & 25,218 & 14,865 & 3,559 \\
\hline 1988 & 1,150 & 123,844 & 82,200 & 303,265 & 37,125 & 15,198 & 3,980 \\
\hline 1989 & 1,335 & 143,730 & 70,500 & 305,142 & 31,074 & 13,069 & 4,286 \\
\hline 1990 & 1,045 & 112,511 & 69,700 & 276,671 & 43,915 & 11,535 & 4,563 \\
\hline 1991 & 663 & 71,443 & 25,600 & 314,292 & 51,788 & 13,103 & 4,773 \\
\hline 1992 & 533 & 57,363 & 9,300 & 254,729 & 92,627 & 12,553 & 4,970 \\
\hline 1993 & 837 & 90,186 & 17,800 & 305,800 & 70,638 & 12,909 & 5,285 \\
\hline 1994 & 730 & 78,601 & 41,100 & 284,136 & 43,610 & 11,994 & 5,455 \\
\hline 1995 & 684 & 73,612 & 35,200 & 266,475 & 34,180 & 12,830 & 5,823 \\
\hline 1996 & 1,042 & 112,268 & 66,300 & 286,535 & 25,286 & 12,846 & 6,063 \\
\hline 1997 & 588 & 63,320 & 31,400 & 256,625 & 54,336 & 13,041 & 6,269 \\
\hline 1998 & 883 & 95,093 & 51,300 & 288,353 & 54,581 & 11,147 & 6,490 \\
\hline 1999 & 701 & 75,497 & 49,200 & 288,788 & 47,691 & 12,638 & 6,698 \\
\hline 2000 & 601 & 64,680 & 45,100 & 280,143 & 36,470 & 7,065 & 6,305 \\
\hline
\end{tabular}


Table 5. Steady-state and transient simulation target wells, Edwards aquifer model, San Antonio region, Texas.

[An " $\mathrm{x}$ " indicates well used as hydraulic-head calibration target for specified simulation. TWDB, Texas Water Development Board; ID, identification number]

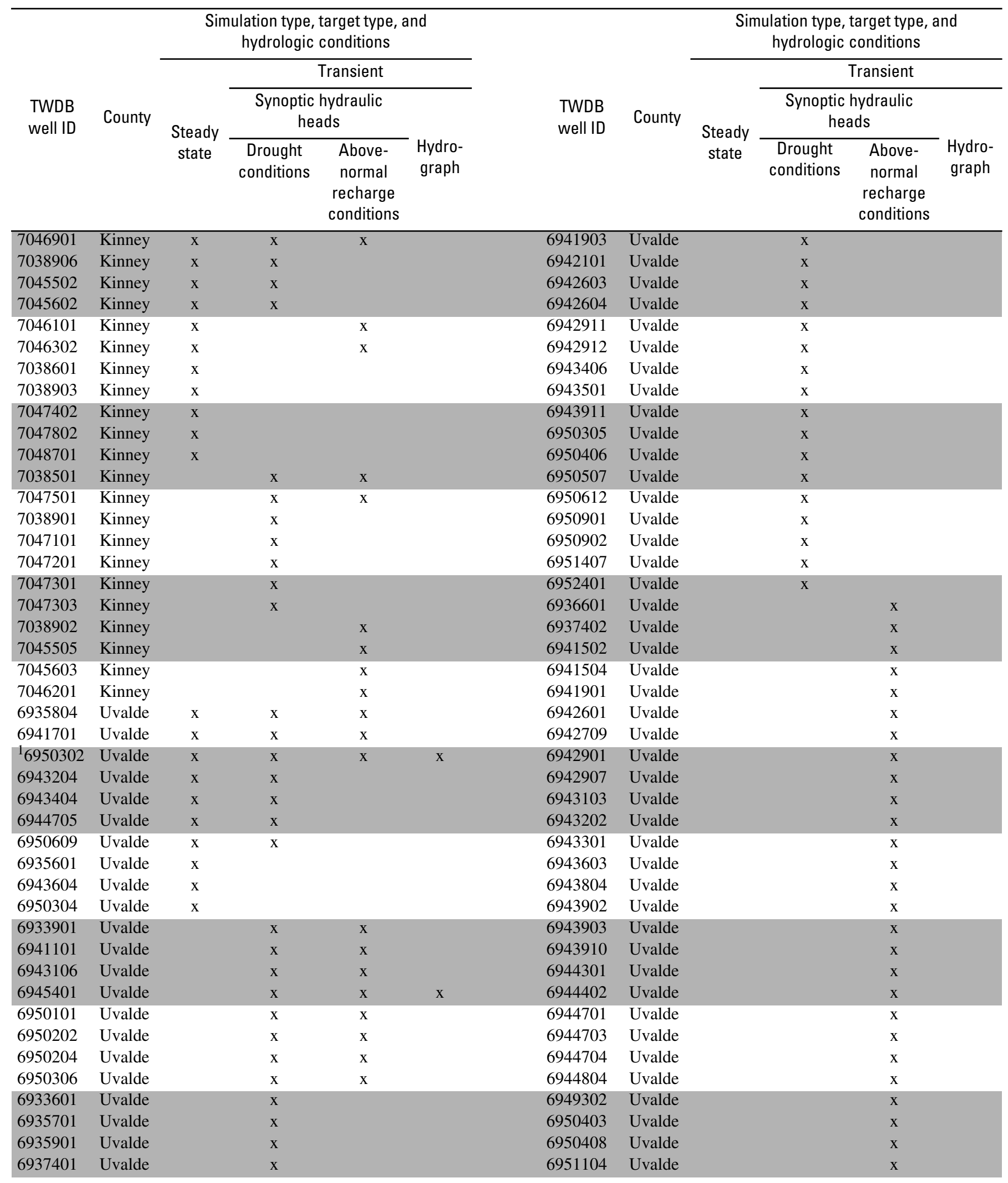


Table 5. Steady-state and transient simulation target wells, Edwards aquifer model, San Antonio region, Texas-Continued.

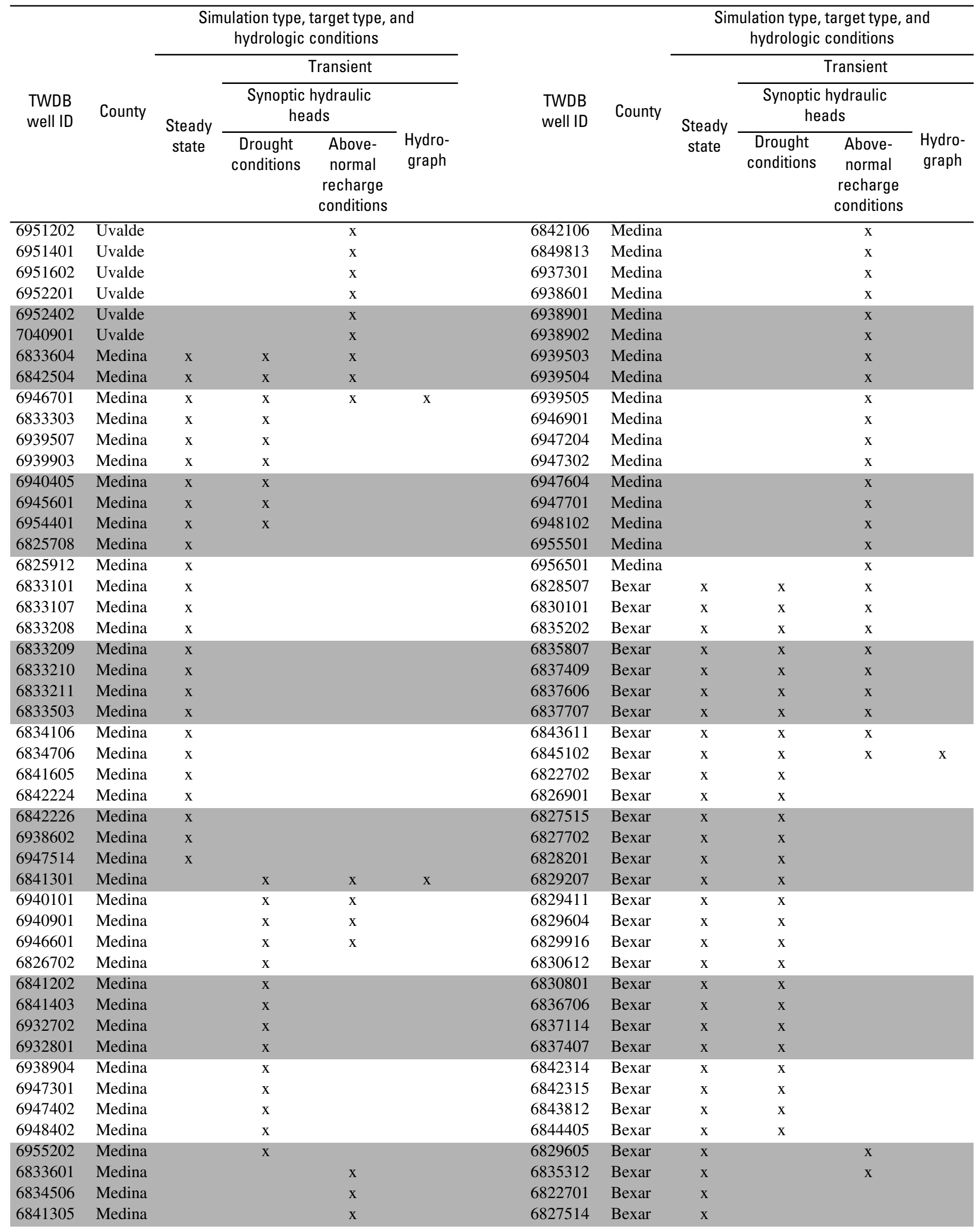


Table 5. Steady-state and transient simulation target wells, Edwards aquifer model, San Antonio region, Texas-Continued.

\begin{tabular}{|c|c|c|c|c|c|c|c|c|c|c|c|}
\hline \multirow{4}{*}{$\begin{array}{l}\text { TWDB } \\
\text { well ID }\end{array}$} & \multirow{4}{*}{ County } & \multicolumn{4}{|c|}{$\begin{array}{l}\text { Simulation type, target type, and } \\
\text { hydrologic conditions }\end{array}$} & \multirow{4}{*}{$\begin{array}{l}\text { TWDB } \\
\text { well ID }\end{array}$} & \multirow{4}{*}{ County } & \multicolumn{4}{|c|}{$\begin{array}{l}\text { Simulation type, target type, and } \\
\text { hydrologic conditions }\end{array}$} \\
\hline & & \multirow{3}{*}{$\begin{array}{l}\text { Steady } \\
\text { state }\end{array}$} & \multicolumn{3}{|c|}{ Transient } & & & \multicolumn{4}{|c|}{ Transient } \\
\hline & & & \multicolumn{2}{|c|}{$\begin{array}{l}\text { Synoptic hydraulic } \\
\text { heads }\end{array}$} & \multirow[b]{2}{*}{$\begin{array}{l}\text { Hydro- } \\
\text { graph }\end{array}$} & & & \multirow{2}{*}{$\begin{array}{l}\text { Steady } \\
\text { state }\end{array}$} & \multicolumn{2}{|c|}{$\begin{array}{l}\text { Synoptic hydraulic } \\
\text { heads }\end{array}$} & \multirow[b]{2}{*}{$\begin{array}{l}\text { Hydro- } \\
\text { graph }\end{array}$} \\
\hline & & & $\begin{array}{l}\text { Drought } \\
\text { conditions }\end{array}$ & $\begin{array}{c}\text { Above- } \\
\text { normal } \\
\text { recharge } \\
\text { conditions }\end{array}$ & & & & & $\begin{array}{c}\text { Drought } \\
\text { conditions }\end{array}$ & $\begin{array}{c}\text { Above- } \\
\text { normal } \\
\text { recharge } \\
\text { conditions }\end{array}$ & \\
\hline 6827701 & Bexar & $\mathrm{X}$ & & & & 6835311 & Bexar & & $\mathrm{X}$ & & \\
\hline 6828704 & Bexar & $\mathrm{x}$ & & & & 6835504 & Bexar & & $\mathrm{x}$ & & \\
\hline 6829502 & Bexar & $\mathrm{x}$ & & & & 6835901 & Bexar & & $\mathrm{x}$ & & \\
\hline 6829815 & Bexar & $\mathrm{x}$ & & & & 6835911 & Bexar & & $\mathrm{x}$ & & \\
\hline 6830706 & Bexar & $\mathrm{x}$ & & & & 6836302 & Bexar & & $\mathrm{x}$ & & \\
\hline 6836709 & Bexar & $\mathrm{x}$ & & & & 6836604 & Bexar & & $\mathrm{x}$ & & \\
\hline 6836713 & Bexar & $\mathrm{x}$ & & & & 6836911 & Bexar & & $\mathrm{x}$ & & \\
\hline 6836812 & Bexar & $\mathrm{x}$ & & & & 6836913 & Bexar & & $\mathrm{x}$ & & \\
\hline 6836813 & Bexar & $\mathrm{x}$ & & & & 6837512 & Bexar & & $\mathrm{x}$ & & \\
\hline 6836910 & Bexar & $\mathrm{x}$ & & & & 6837513 & Bexar & & $\mathrm{x}$ & & \\
\hline 6836930 & Bexar & $\mathrm{x}$ & & & & 6837514 & Bexar & & $\mathrm{x}$ & & \\
\hline 6837126 & Bexar & $\mathrm{x}$ & & & & 6838109 & Bexar & & $\mathrm{x}$ & & \\
\hline 6837408 & Bexar & $\mathrm{x}$ & & & & 6838301 & Bexar & & $\mathrm{x}$ & & \\
\hline 6837411 & Bexar & $\mathrm{x}$ & & & & 6843205 & Bexar & & $\mathrm{x}$ & & \\
\hline 6837517 & Bexar & $\mathrm{x}$ & & & & 6843404 & Bexar & & $\mathrm{x}$ & & \\
\hline 6837715 & Bexar & $\mathrm{x}$ & & & & 6843507 & Bexar & & $\mathrm{x}$ & & \\
\hline 6844602 & Bexar & $\mathrm{x}$ & & & & 6828910 & Bexar & & & $\mathrm{x}$ & \\
\hline 6828705 & Bexar & & $\mathrm{x}$ & $\mathrm{x}$ & & 6829103 & Bexar & & & $\mathrm{x}$ & \\
\hline 6829304 & Bexar & & $\mathrm{x}$ & $\mathrm{x}$ & & 6829506 & Bexar & & & $\mathrm{x}$ & \\
\hline 6829701 & Bexar & & $\mathrm{x}$ & $\mathrm{x}$ & & 6829811 & Bexar & & & $\mathrm{x}$ & \\
\hline 6830514 & Bexar & & $\mathrm{x}$ & $\mathrm{x}$ & & 6829913 & Bexar & & & $\mathrm{x}$ & \\
\hline 6830802 & Bexar & & $\mathrm{x}$ & $\mathrm{x}$ & & 6829914 & Bexar & & & $\mathrm{x}$ & \\
\hline 6834602 & Bexar & & $\mathrm{x}$ & $\mathrm{x}$ & & 6830211 & Bexar & & & $\mathrm{x}$ & $\mathrm{x}$ \\
\hline 6834603 & Bexar & & $\mathrm{x}$ & $\mathrm{x}$ & & 6830220 & Bexar & & & $\mathrm{x}$ & \\
\hline${ }^{2} 6837203$ & Bexar & $\mathrm{x}$ & $\mathrm{x}$ & $\mathrm{x}$ & $\mathrm{x}$ & 6830705 & Bexar & & & $\mathrm{x}$ & \\
\hline 6843807 & Bexar & & $\mathrm{x}$ & $\mathrm{x}$ & & 6830807 & Bexar & & & $\mathrm{x}$ & \\
\hline 6826804 & Bexar & & $\mathrm{x}$ & & & 6836104 & Bexar & & & $\mathrm{x}$ & \\
\hline 6827608 & Bexar & & $\mathrm{x}$ & & & 6836105 & Bexar & & & $\mathrm{x}$ & \\
\hline 6828908 & Bexar & & $\mathrm{x}$ & & & 6836407 & Bexar & & & $\mathrm{x}$ & \\
\hline 6829508 & Bexar & & $\mathrm{x}$ & & & 6837103 & Bexar & & & $\mathrm{x}$ & \\
\hline 6829709 & Bexar & & $\mathrm{x}$ & & & 6837511 & Bexar & & & $\mathrm{x}$ & \\
\hline 6829917 & Bexar & & $\mathrm{x}$ & & & 6844109 & Bexar & & & $\mathrm{x}$ & \\
\hline 6830404 & Bexar & & $\mathrm{x}$ & & & 6844214 & Bexar & & & $\mathrm{x}$ & \\
\hline 6830513 & Bexar & & $\mathrm{x}$ & & & 6845301 & Bexar & & & $\mathrm{x}$ & \\
\hline 6830707 & Bexar & & $\mathrm{x}$ & & & 6845901 & Bexar & & & $\mathrm{x}$ & \\
\hline 6830901 & Bexar & & $\mathrm{x}$ & & & 6816703 & Comal & $\mathrm{x}$ & $\mathrm{x}$ & $\mathrm{x}$ & \\
\hline 6834301 & Bexar & & $\mathrm{x}$ & & & 6816801 & Comal & $\mathrm{x}$ & $\mathrm{x}$ & $\mathrm{x}$ & $\mathrm{x}$ \\
\hline
\end{tabular}


Table 5. Steady-state and transient simulation target wells, Edwards aquifer model, San Antonio region, Texas-Continued.

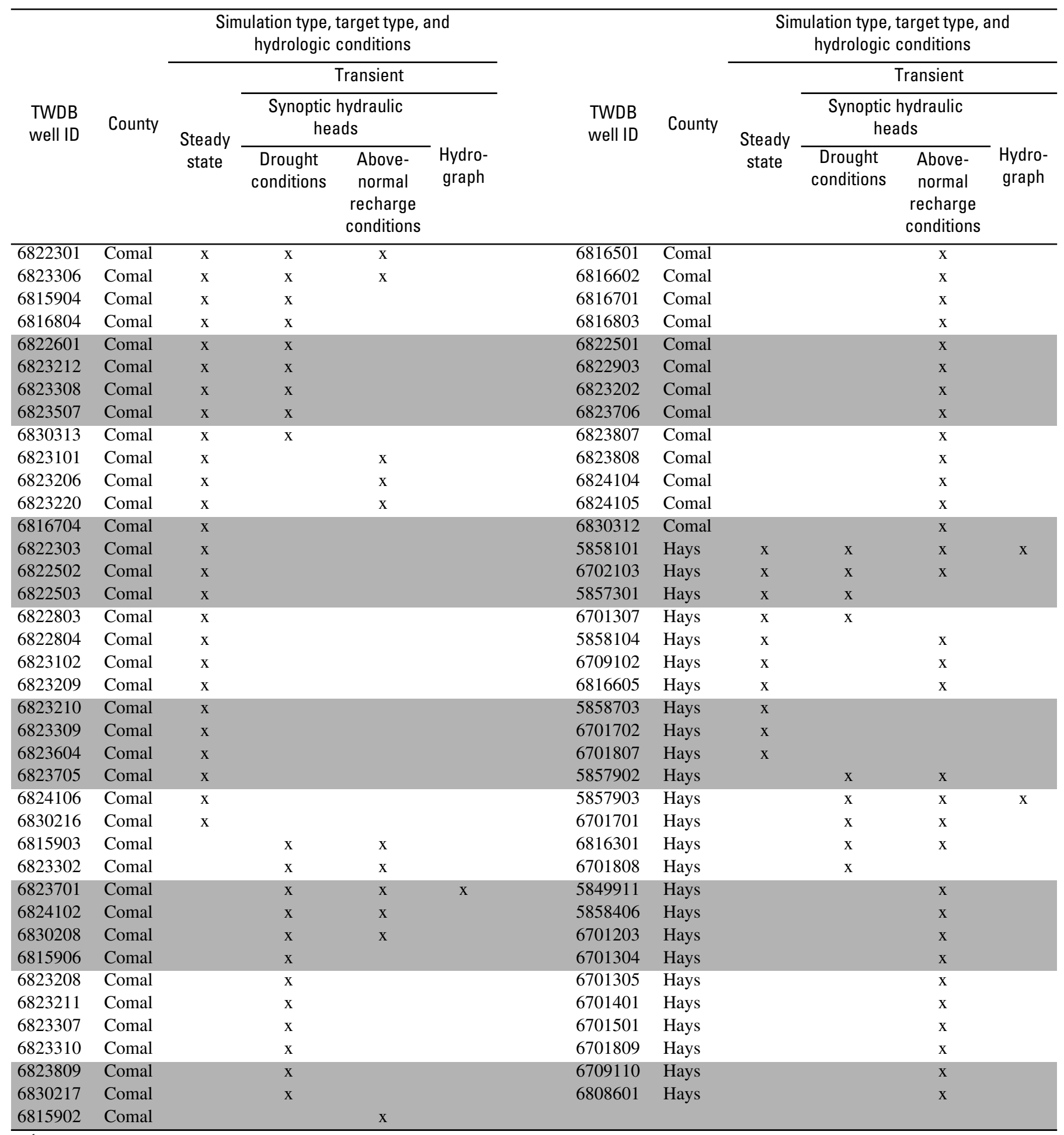

${ }^{1}$ Uvalde County index well.

${ }^{2}$ Bexar County index well. 
Table 6. Summary of changes from initial values for steady-state calibration, Edwards aquifer model, San Antonio region, Texas.

\begin{tabular}{lc}
\hline \multicolumn{1}{c}{ Parameter } & Changes in parameter from initial values \\
\hline Recharge rate & Increased by 50 percent for Nueces-West Nueces River and Onion Creek subzones; reduced by \\
& 25 percent for Cibolo Creek and Dry Comal Creek subzone (fig. 20; table 7) \\
Hydraulic conductivity & $\begin{array}{c}\text { Decreased in parts of Kinney County and the recharge zone; decreased south of the 1,000- } \\
\text { milligrams per liter dissolved solids concentration line; increased for some conduit segments }\end{array}$ \\
Conduit segments & $\begin{array}{c}\text { Shifted positions of three conduit segments in Comal County; deleted southwest-to-northeast- } \\
\text { trending segment east of Hueco Springs; added segment connecting Comal and San Marcos }\end{array}$ \\
& Springs (fig. 7) \\
Drain conductance & Reduced for San Pedro Springs by about two orders of magnitude; increased for Comal and San \\
& Marcos Springs by about a factor of two \\
\hline
\end{tabular}

Table 7. Estimated and simulated recharge rates, by subzone of the recharge zone, steady-state calibration, Edwards aquifer model, San Antonio region, Texas.

[Estimated recharge rates for San Antonio segment of Edwards aquifer computed by U.S. Geological Survey and reported annually. Estimated recharge rates for Barton Springs segment of Edwards aquifer for 1980 from Slade and others (1986, table 4). Factor is percentage of estimated recharge rate used in Edwards aquifer model, if estimated and simulated recharge rates are not the same. NC indicates that estimated and simulated recharge rates are the same. Simulated recharge rate equals estimated recharge rate times factor, if estimated and simulated recharge rates are not the same. Estimated and simulated recharge rates in acre-feet per year]

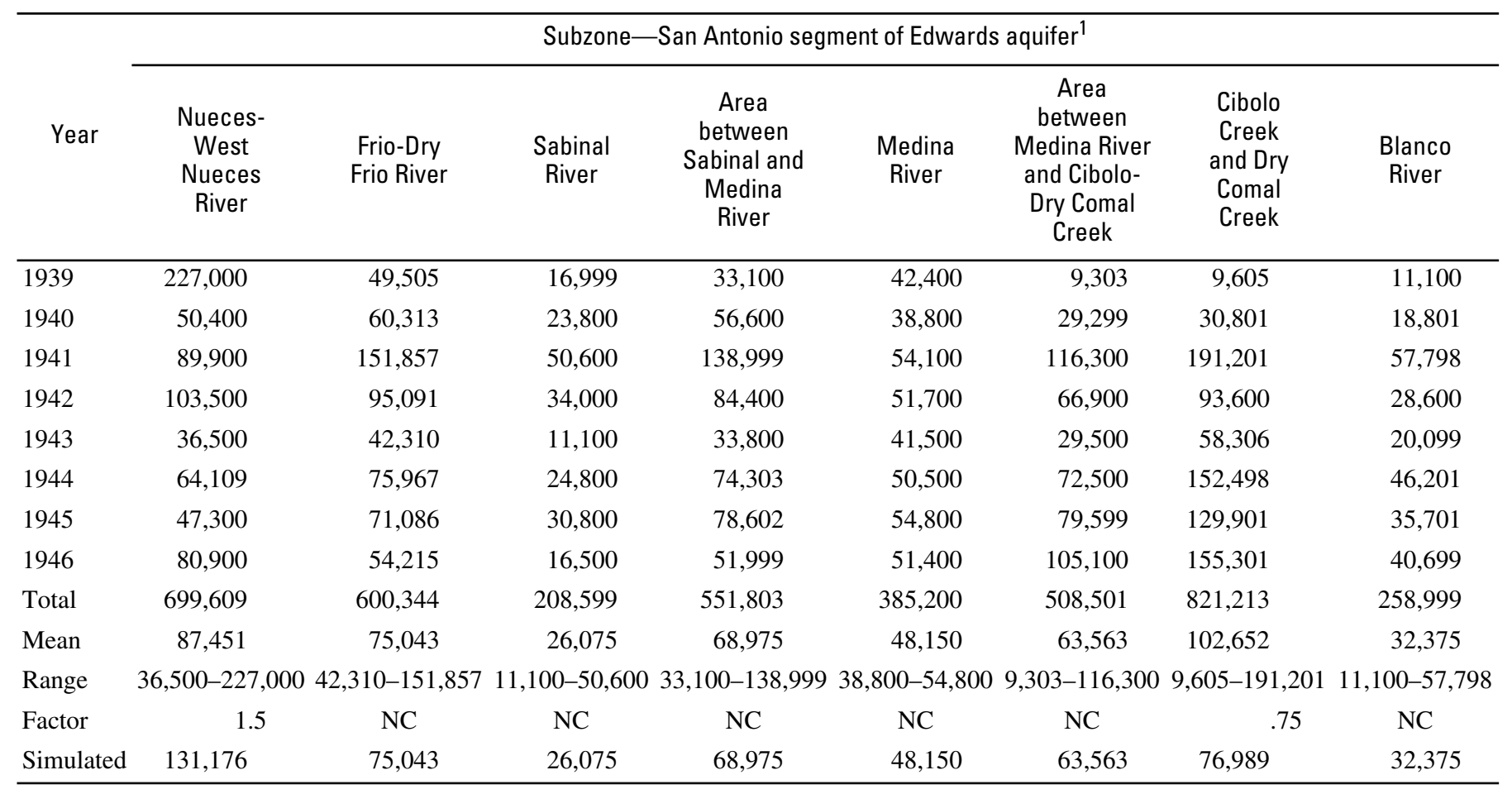

\begin{tabular}{lcccccc}
\hline & \multicolumn{5}{c}{ Subzone-Barton Springs segment of the Edwards aquifer ${ }^{2}$} \\
\cline { 2 - 6 } & Onion Creek & Little Bear Creek & Bear Creek & Slaughter Creek & Williamson Creek & Barton Creek \\
\hline 1980 & 14,272 & 4,290 & 3,992 & 4,996 & 2,565 & 13,578 \\
Factor & 1.5 & $\mathrm{NC}$ & $\mathrm{NC}$ & $\mathrm{NC}$ & $\mathrm{NC}$ & $\mathrm{NC}$ \\
Simulated & 21,408 & 4,290 & 3,992 & 4,996 & 2,565 & 13,578 \\
\hline
\end{tabular}

\footnotetext{
${ }^{1}$ Excludes Guadalupe River subzone.

${ }^{2}$ Excludes Colorado River subzone.
} 
Table 8. Steady-state calibration target wells and residuals, Edwards aquifer model, San Antonio region, Texas.

[TWDB, Texas Water Development Board; ID, identification number; DD.MMSS, degrees.minutes/seconds; ft, feet; RMS error, root mean square error. Residual is simulated water level minus measured water level; mean absolute difference is sum of absolute values of residuals divided by number of wells; mean algebraic 'difference is algebraic sum of residuals divided by number of wells.]

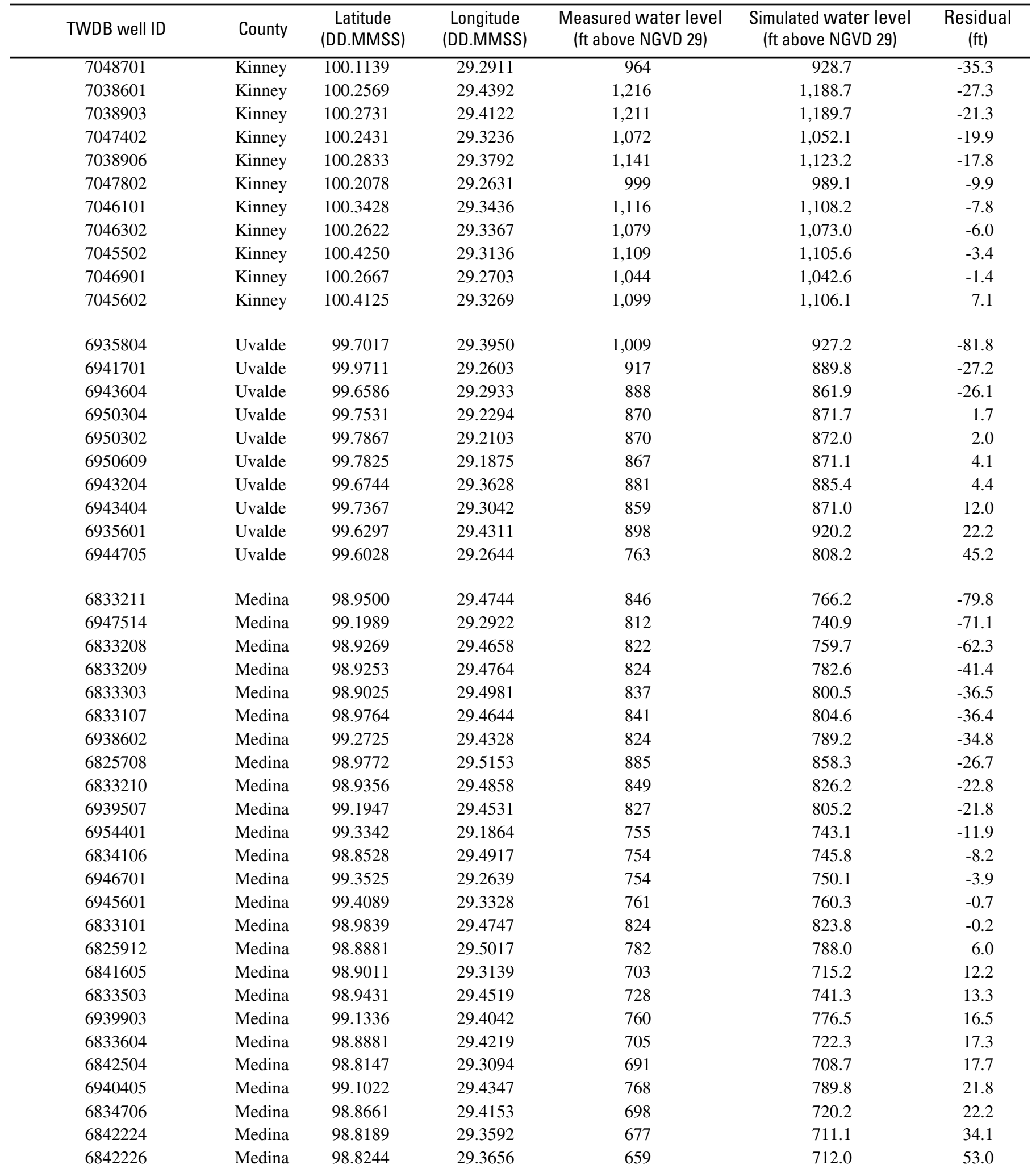


Table 8. Steady-state calibration target wells and residuals, Edwards aquifer model, San Antonio region, Texas-Continued.

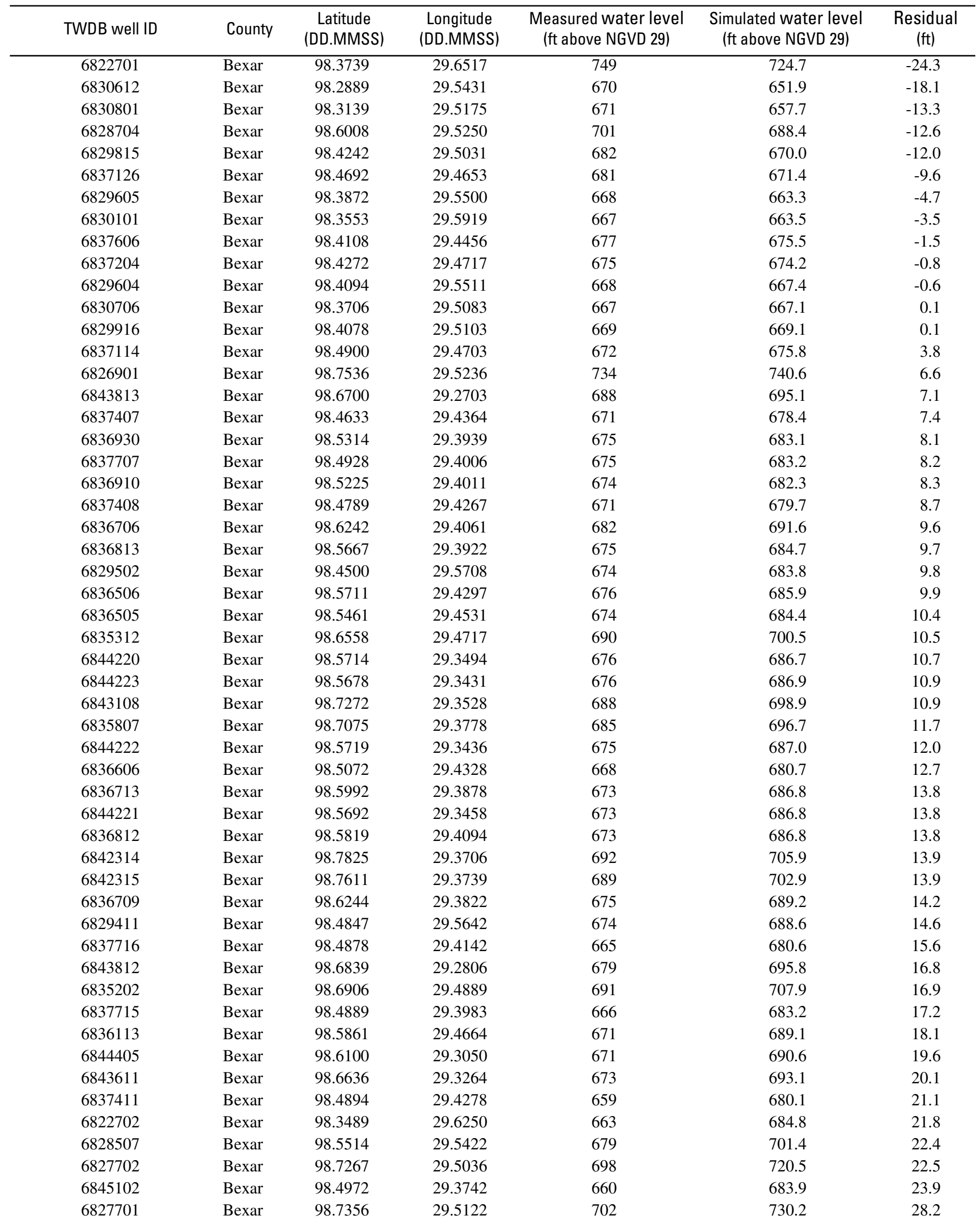


Table 8. Steady-state calibration target wells and residuals, Edwards aquifer model, San Antonio region, Texas—Continued.

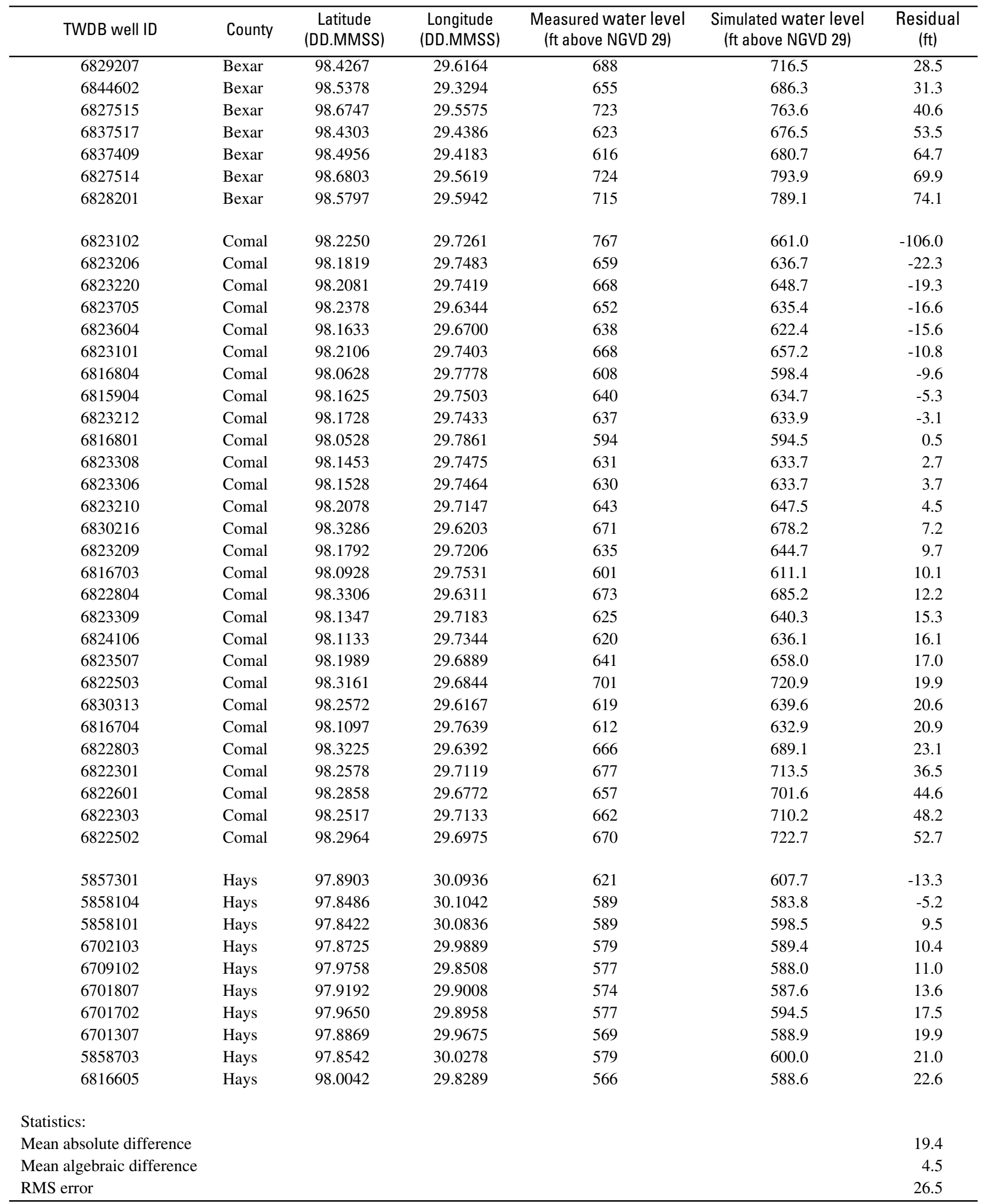


Table 9. Measured and simulated springflows for steady-state calibration, Edwards aquifer model, San Antonio region, Texas.

[In cubic feet per second. Mean and median springflows for 1939-46; simulated is model-computed springflow for steady-state simulation]

\begin{tabular}{|c|c|c|c|c|c|c|c|c|c|c|}
\hline \multirow[b]{2}{*}{ Year } & \multicolumn{10}{|c|}{ Measured } \\
\hline & \multicolumn{2}{|c|}{ Comal Springs } & \multicolumn{2}{|c|}{ San Marcos Springs } & \multicolumn{2}{|c|}{ Leona Springs } & \multicolumn{2}{|c|}{ San Antonio Springs } & \multicolumn{2}{|c|}{ San Pedro Springs } \\
\hline 1939 & 297 & 301 & 98 & 103 & 21 & 20 & 4 & 0 & 5 & 4 \\
\hline 1941 & 340 & 339 & 182 & 170 & 21 & 23 & 28 & 29 & 9 & 9 \\
\hline 1942 & 346 & 333 & 153 & 135 & 26 & 27 & 29 & 23 & 9 & 8 \\
\hline 1943 & 337 & 325 & 133 & 134 & 21 & 20 & 13 & 10 & 7 & 6 \\
\hline 1946 & 356 & 358 & 181 & 173 & 3 & 2 & 16 & 9 & 7 & 6 \\
\hline Mean & 332 & 326 & 153 & 147 & 16 & 17 & 16 & 12 & 7 & 6 \\
\hline \multirow[t]{2}{*}{ Median } & 341 & 332 & 167 & 152 & 20 & 19 & 14 & 10 & 7 & 6 \\
\hline & \multicolumn{10}{|c|}{ Simulated } \\
\hline
\end{tabular}

Table 10. Estimated and simulated recharge rates and multiplication factors used for years with greatly above-normal rainfall and recharge, Edwards aquifer model, San Antonio region, Texas.

[Estimated and simulated recharge rates in acre-feet per year. "Estimated" is recharge rate estimated by U.S. Geological Survey and reported annually. Factor is percentage of estimated recharge rate. "Simulated" is recharge rate used in Edwards aquifer model (annual total of recharge rates for monthly model stress periods). Simulated recharge rate equals estimated recharge rate times factor.]

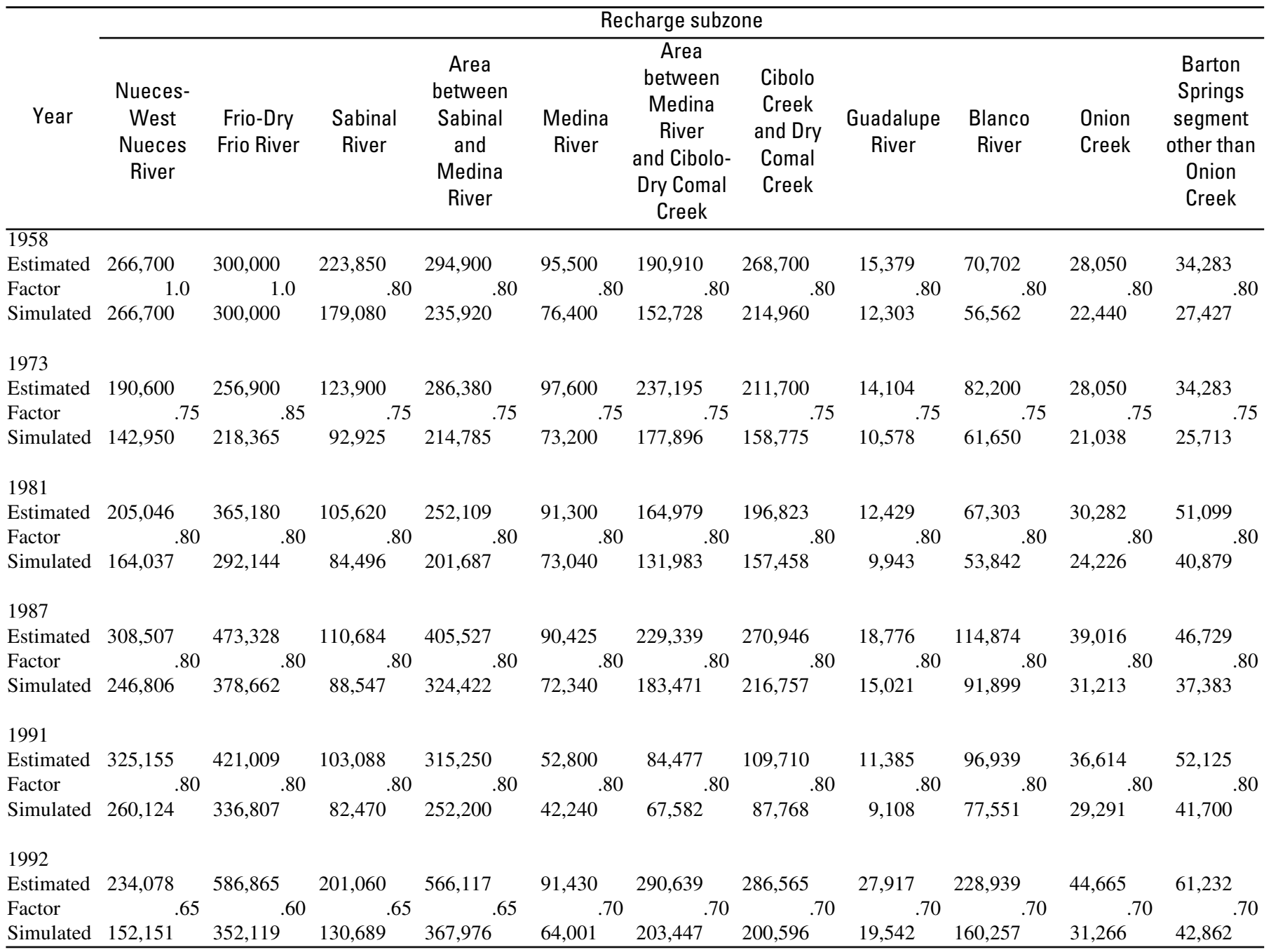


Table 11. Initial and final calibrated drain parameters for springs, Edwards aquifer model, San Antonio region, Texas.

[ft, feet; $\mathrm{ft}^{2} / \mathrm{d}$, feet squared per day.]

\begin{tabular}{|c|c|c|c|c|}
\hline \multirow{2}{*}{ Spring } & \multicolumn{2}{|c|}{$\begin{array}{c}\text { Drain elevation } \\
\text { (ft above NGVD 29) }\end{array}$} & \multicolumn{2}{|c|}{$\begin{array}{l}\text { Drain conductance } \\
\left(\mathrm{ft}^{2} / \mathrm{d}\right)\end{array}$} \\
\hline & Initial & Calibrated & Initial & Calibrated \\
\hline Comal & ${ }^{1} 583$ & 609 & $1.32 \times 10^{6}$ & $4.62 \times 10^{6}$ \\
\hline San Marcos & ${ }^{1} 558$ & 584 & $1.32 \times 10^{6}$ & $4.62 \times 10^{6}$ \\
\hline Leona & ${ }^{2} 839$ & 839 & $1.32 \times 10^{6}$ & $2.00 \times 10^{5}$ \\
\hline San Antonio & ${ }^{2} 670$ & 670 & $1.32 \times 10^{6}$ & $6.60 \times 10^{6}$ \\
\hline San Pedro & ${ }^{2} 660$ & 660 & $1.32 \times 10^{6}$ & $3.30 \times 10^{4}$ \\
\hline Barton & ${ }^{2} 432$ & 432 & $1.00 \times 10^{6}$ & $1.00 \times 10^{6}$ \\
\hline Las Moras & ${ }^{2} 1,105$ & 1,105 & $1.32 \times 10^{6}$ & $1.32 \times 10^{6}$ \\
\hline
\end{tabular}

${ }^{1}$ Based on the altitude of the streamflow-gaging station used to estimate the springflow.

${ }^{2}$ Based on the land-surface altitude of the spring orifice or spring pool, estimated from USGS topographic maps.

Table 12. Summary of changes in parameter values (1) from initial calibrated steady-state simulation, (2) from USGS-estimated recharge rates, and (3) from the initial uniform storativity distribution for the transient simulation; and changes from the calibrated transient simulation for transient simulation testing, Edwards aquifer model, San Antonio region, Texas.

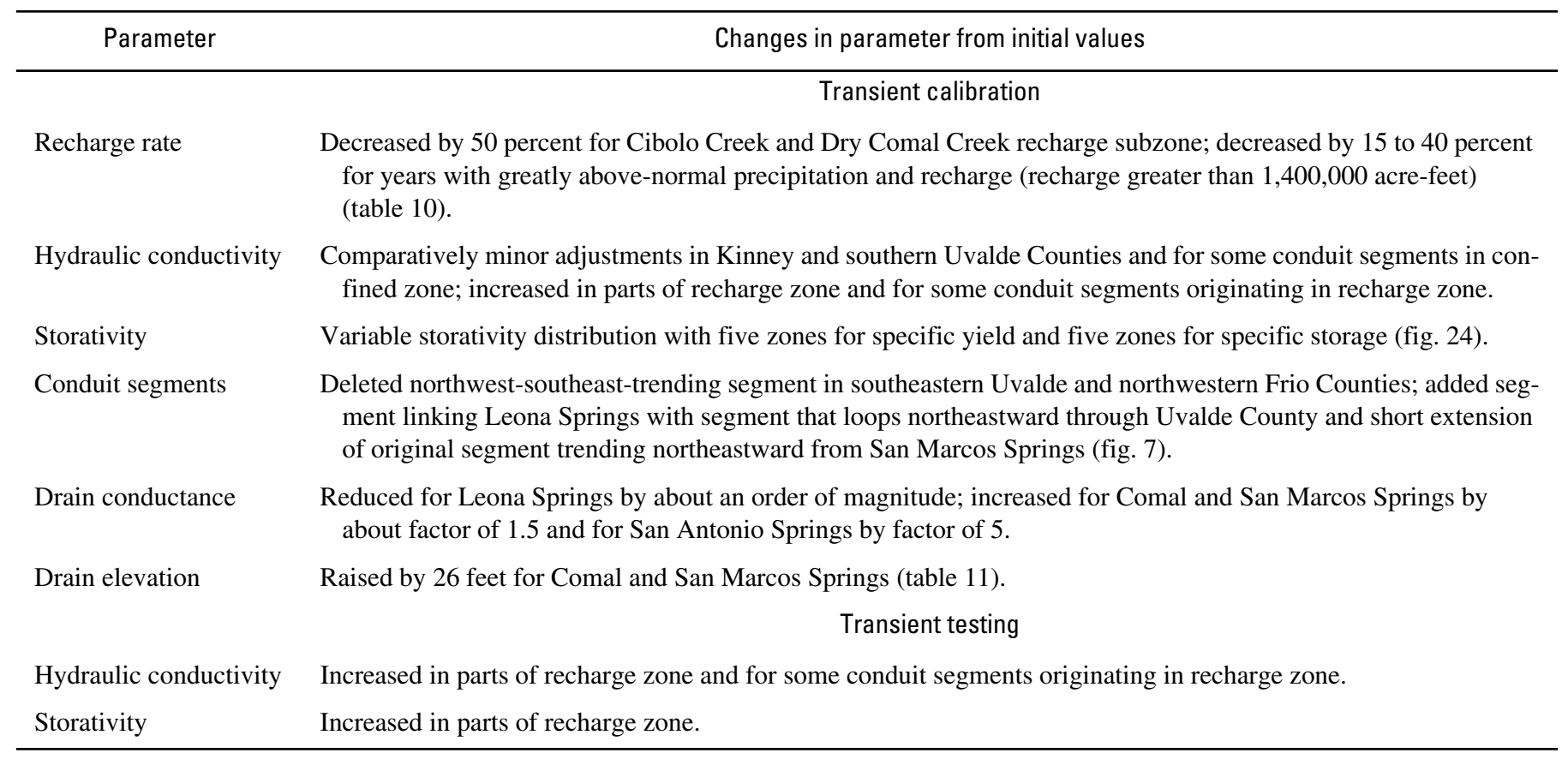


Table 13. Transient simulation target wells and residuals for drought conditions for the Edwards aquifer model.

[Residual is the simulated water level minus the measured water level; mean absolute difference is the sum of the absolute values of the residuals divided by the number of wells; mean algebraic difference is the algebraic sum of the residuals divided by the number of wells; RMS error, root mean square error; TWDB, Texas Water Development Board; ID, identification number; ft, feet]

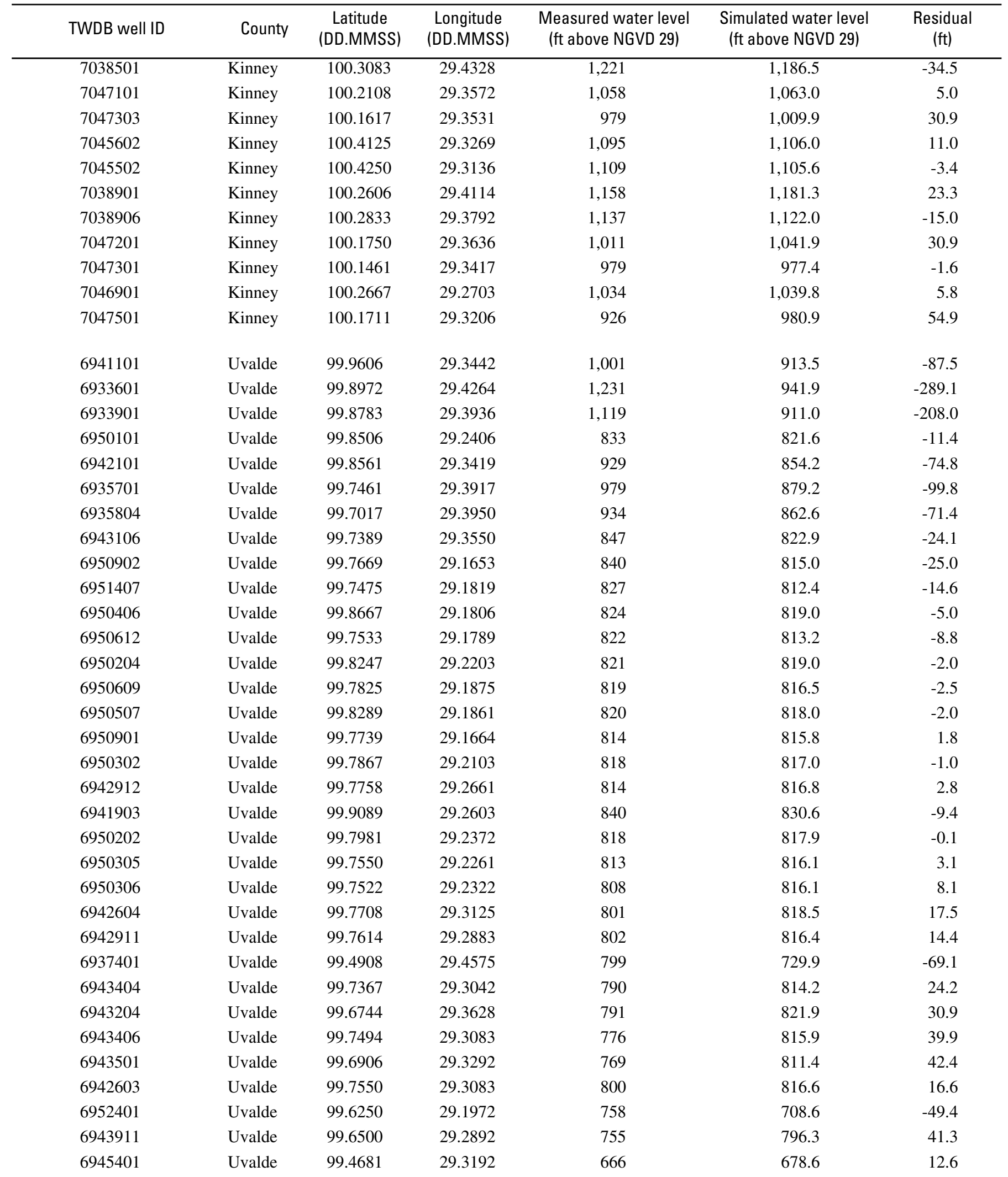


Table 13. Transient simulation target wells and residuals for drought conditions for the Edwards aquifer model—Continued.

\begin{tabular}{|c|c|c|c|c|c|c|}
\hline TWDB well ID & County & $\begin{array}{c}\text { Latitude } \\
\text { (DD.MMSS) }\end{array}$ & $\begin{array}{l}\text { Longitude } \\
\text { (DD.MMSS) }\end{array}$ & $\begin{array}{c}\text { Measured water level } \\
\text { (ft above NGVD 29) }\end{array}$ & $\begin{array}{l}\text { Simulated water level } \\
\text { (ft above NGVD 29) }\end{array}$ & $\begin{array}{l}\text { Residual } \\
\text { (ft) }\end{array}$ \\
\hline 6941701 & Uvalde & 99.9711 & 29.2603 & 839 & 843.5 & 4.5 \\
\hline 6935901 & Uvalde & 99.6456 & 29.3869 & 717 & 826.0 & 109.0 \\
\hline 6932702 & Medina & 99.0939 & 29.5258 & 976 & 775.5 & -200.5 \\
\hline 6833303 & Medina & 98.9025 & 29.4981 & 783 & 660.7 & -122.3 \\
\hline 6940101 & Medina & 99.1228 & 29.4906 & 775 & 737.7 & -37.3 \\
\hline 6939507 & Medina & 99.1947 & 29.4531 & 740 & 703.2 & -36.8 \\
\hline 6945601 & Medina & 99.4089 & 29.3328 & 663 & 674.3 & 11.3 \\
\hline 6954401 & Medina & 99.3342 & 29.1864 & 659 & 661.0 & 2.0 \\
\hline 6947402 & Medina & 99.2097 & 29.3331 & 642 & 656.3 & 14.3 \\
\hline 6842504 & Medina & 98.8147 & 29.3094 & 626 & 628.1 & 2.1 \\
\hline 6946601 & Medina & 99.2786 & 29.3319 & 659 & 661.8 & 2.8 \\
\hline 6841202 & Medina & 98.9297 & 29.3353 & 615 & 635.5 & 20.5 \\
\hline 6948402 & Medina & 99.1069 & 29.3247 & 636 & 648.6 & 12.6 \\
\hline 6955202 & Medina & 99.2006 & 29.2269 & 640 & 649.5 & 9.5 \\
\hline 6947301 & Medina & 99.1600 & 29.3597 & 634 & 652.8 & 18.8 \\
\hline 6833604 & Medina & 98.8881 & 29.4219 & 628 & 633.0 & 5.0 \\
\hline 6939903 & Medina & 99.1336 & 29.4042 & 659 & 679.2 & 20.2 \\
\hline 6940901 & Medina & 99.0008 & 29.4094 & 637 & 640.1 & 3.1 \\
\hline 6828201 & Bexar & 98.5797 & 29.5942 & 686 & 600.2 & -85.8 \\
\hline 6829508 & Bexar & 98.4203 & 29.5775 & 619 & 601.4 & -17.6 \\
\hline 6830901 & Bexar & 98.2669 & 29.5128 & 646 & 607.4 & -38.6 \\
\hline 6829411 & Bexar & 98.4847 & 29.5642 & 641 & 571.2 & -69.8 \\
\hline 6829916 & Bexar & 98.4078 & 29.5103 & 636 & 604.0 & -32.0 \\
\hline 6829709 & Bexar & 98.4617 & 29.5028 & 623 & 599.8 & -23.2 \\
\hline 6828705 & Bexar & 98.6247 & 29.5014 & 623 & 594.8 & -28.2 \\
\hline 6828908 & Bexar & 98.5350 & 29.5183 & 621 & 594.6 & -26.4 \\
\hline 6827515 & Bexar & 98.6747 & 29.5575 & 653 & 500.6 & -152.4 \\
\hline 6834301 & Bexar & 98.7789 & 29.4753 & 629 & 628.4 & -0.6 \\
\hline 6828507 & Bexar & 98.5514 & 29.5422 & 620 & 591.9 & -28.1 \\
\hline 6837203 & Bexar & 98.4322 & 29.4708 & 621 & 608.5 & -12.5 \\
\hline 6826804 & Bexar & 98.7978 & 29.5242 & 638 & 632.6 & -5.4 \\
\hline 6835911 & Bexar & 98.6506 & 29.3944 & 626 & 609.4 & -16.6 \\
\hline 6836507 & Bexar & 98.5442 & 29.4264 & 624 & 610.0 & -14.0 \\
\hline 6842314 & Bexar & 98.7825 & 29.3706 & 625 & 623.0 & -2.0 \\
\hline 6836410 & Bexar & 98.6236 & 29.4558 & 619 & 606.5 & -12.5 \\
\hline 6830514 & Bexar & 98.3194 & 29.5789 & 623 & 606.4 & -16.6 \\
\hline
\end{tabular}


Table 13. Transient simulation target wells and residuals for drought conditions for the Edwards aquifer model—Continued.

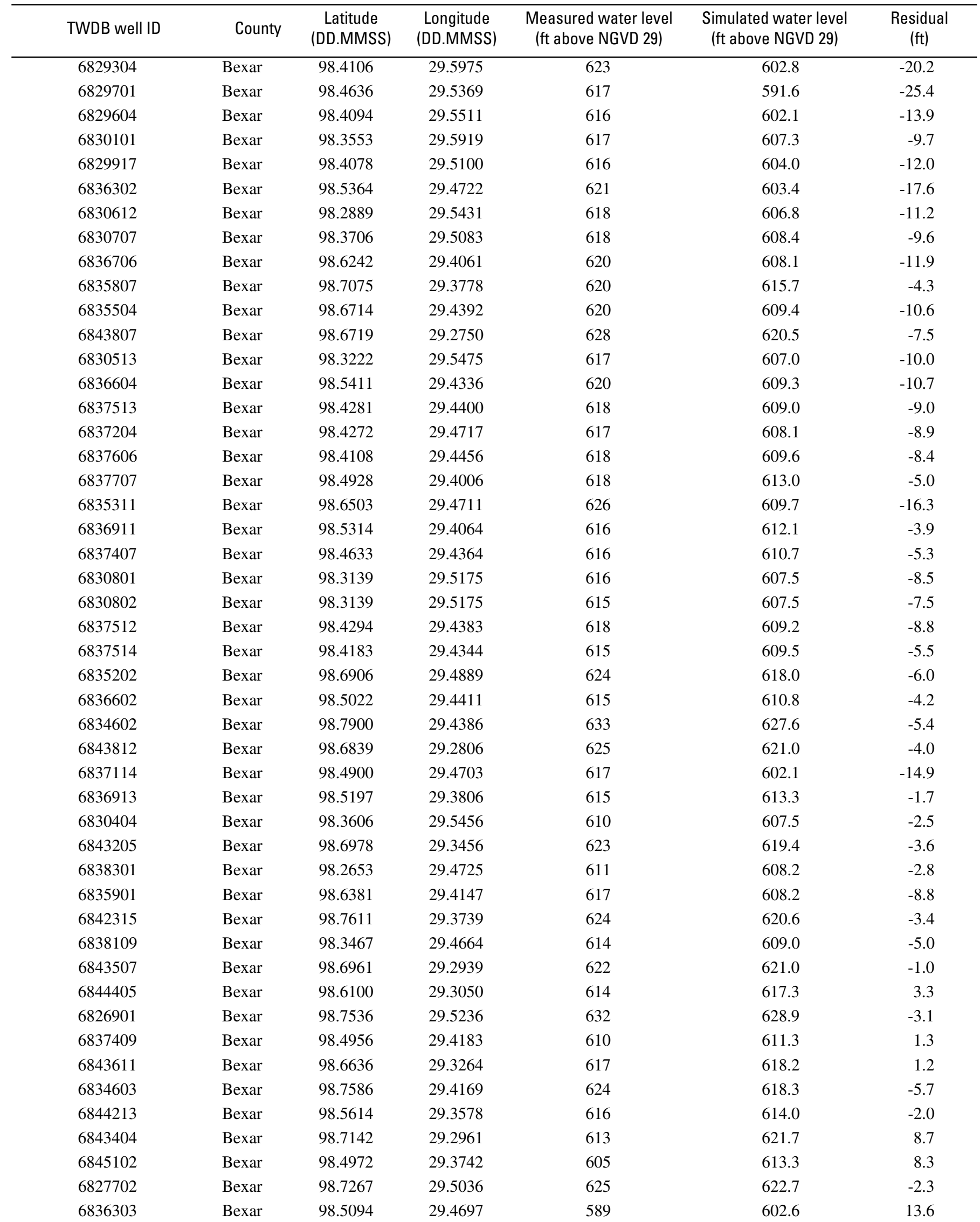


Table 13. Transient simulation target wells and residuals for drought conditions for the Edwards aquifer model—Continued.

\begin{tabular}{|c|c|c|c|c|c|c|}
\hline TWDB well ID & County & $\begin{array}{c}\text { Latitude } \\
\text { (DD.MMSS) }\end{array}$ & $\begin{array}{l}\text { Longitude } \\
\text { (DD.MMSS) }\end{array}$ & $\begin{array}{l}\text { Measured water level } \\
\text { (ft above NGVD 29) }\end{array}$ & $\begin{array}{c}\text { Simulated water level } \\
\text { (ft above NGVD 29) }\end{array}$ & $\begin{array}{c}\text { Residual } \\
\text { (ft) }\end{array}$ \\
\hline 6843605 & Bexar & 98.6533 & 29.3269 & 603 & 617.9 & 14.9 \\
\hline 6822702 & Bexar & 98.3489 & 29.6250 & 620 & 620.1 & 0.1 \\
\hline 6822301 & Comal & 98.2578 & 29.7119 & 649 & 640.2 & -8.8 \\
\hline 6815906 & Comal & 98.1597 & 29.7786 & 633 & 614.5 & -18.5 \\
\hline 6823212 & Comal & 98.1728 & 29.7433 & 618 & 605.1 & -12.9 \\
\hline 6823307 & Comal & 98.1594 & 29.7461 & 616 & 605.0 & -11.0 \\
\hline 6823308 & Comal & 98.1453 & 29.7475 & 613 & 604.9 & -8.1 \\
\hline 6823302 & Comal & 98.1389 & 29.7161 & 614 & 606.1 & -7.9 \\
\hline 6823306 & Comal & 98.1528 & 29.7464 & 612 & 605.0 & -7.0 \\
\hline 6816804 & Comal & 98.0628 & 29.7778 & 596 & 591.8 & -4.2 \\
\hline 6815904 & Comal & 98.1625 & 29.7503 & 612 & 606.5 & -5.5 \\
\hline 6823507 & Comal & 98.1989 & 29.6889 & 620 & 613.4 & -6.6 \\
\hline 6824102 & Comal & 98.1069 & 29.7444 & 610 & 604.3 & -5.7 \\
\hline 6815903 & Comal & 98.1414 & 29.7575 & 618 & 605.2 & -12.8 \\
\hline 6823701 & Comal & 98.2164 & 29.6486 & 615 & 611.2 & -3.8 \\
\hline 6830208 & Comal & 98.3194 & 29.6097 & 615 & 615.3 & 0.3 \\
\hline 6830217 & Comal & 98.3006 & 29.6181 & 614 & 615.1 & 1.1 \\
\hline 6823310 & Comal & 98.1253 & 29.7306 & 603 & 605.0 & 2.0 \\
\hline 6822601 & Comal & 98.2858 & 29.6772 & 628 & 633.5 & 5.5 \\
\hline 6823208 & Comal & 98.1936 & 29.7347 & 618 & 605.3 & -12.7 \\
\hline 6823809 & Comal & 98.1928 & 29.6594 & 588 & 604.6 & 16.6 \\
\hline 6816801 & Comal & 98.0528 & 29.7861 & 578 & 589.0 & 11.0 \\
\hline 6816703 & Comal & 98.0928 & 29.7531 & 593 & 599.3 & 6.3 \\
\hline 6830313 & Comal & 98.2572 & 29.6167 & 576 & 605.7 & 29.7 \\
\hline 5857301 & Hays & 97.8903 & 30.0936 & 596 & 551.6 & -44.4 \\
\hline 6816301 & Hays & 98.0214 & 29.8714 & 601 & 589.2 & -11.8 \\
\hline 5858101 & Hays & 97.8422 & 30.0836 & 560 & 548.3 & -11.7 \\
\hline 6701808 & Hays & 97.9194 & 29.9014 & 582 & 585.0 & 3.0 \\
\hline 5857902 & Hays & 97.8958 & 30.0083 & 574 & 582.1 & 8.1 \\
\hline 5857903 & Hays & 97.8861 & 30.0381 & 561 & 575.9 & 14.9 \\
\hline 6701701 & Hays & 97.9639 & 29.8956 & 568 & 586.2 & 18.2 \\
\hline 6701307 & Hays & 97.8869 & 29.9675 & 565 & 584.8 & 19.8 \\
\hline 6702103 & Hays & 97.8725 & 29.9889 & 519 & 584.6 & 65.6 \\
\hline \multicolumn{7}{|l|}{ Statistics: } \\
\hline Mean absolute difference & & & & & & 23.0 \\
\hline Mean algebraic difference & & & & & & -11.0 \\
\hline RMS error & & & & & & 45.5 \\
\hline
\end{tabular}


Table 14. Transient simulation target wells and residuals for above-normal rainfall and recharge conditions, Edwards aquifer model, San Antonio region, Texas.

[TWDB, Texas Water Development Board; ID, identification number; DD.MMSS, degrees.minutes/seconds; ft, feet; RMS error, root mean square error. Residual is simulated water level minus measured water level; mean absolute difference is sum of absolute values of residuals divided by number of wells; mean algebraic difference is algebraic sum of residuals divided by number of wells.]

\begin{tabular}{|c|c|c|c|c|c|c|}
\hline TWDB well ID & County & $\begin{array}{c}\text { Latitude } \\
\text { (DD.MMSS) }\end{array}$ & $\begin{array}{l}\text { Longitude } \\
\text { (DD.MMSS) }\end{array}$ & $\begin{array}{l}\text { Measured water level } \\
\text { (ft above NGVD 29) }\end{array}$ & $\begin{array}{l}\text { Simulated water level } \\
\text { (ft above NGVD 29) }\end{array}$ & $\begin{array}{l}\text { Residual } \\
\text { (ft) }\end{array}$ \\
\hline 7038501 & Kinney & 100.3083 & 29.4328 & 1,240 & $1,179.8$ & -60.2 \\
\hline 7046302 & Kinney & 100.2622 & 29.3367 & 1,097 & $1,071.9$ & -25.1 \\
\hline 7046101 & Kinney & 100.3428 & 29.3436 & 1,120 & $1,100.2$ & -19.8 \\
\hline 7046201 & Kinney & 100.3042 & 29.3453 & 1,112 & $1,094.0$ & -18.0 \\
\hline 7046901 & Kinney & 100.2667 & 29.2703 & 1,046 & $1,043.9$ & -2.1 \\
\hline 7038902 & Kinney & 100.2617 & 29.4131 & 1,183 & $1,191.1$ & 8.1 \\
\hline 7045603 & Kinney & 100.4125 & 29.3278 & 1,093 & $1,105.7$ & 12.7 \\
\hline 6933901 & Uvalde & 99.8783 & 29.3936 & 1,126 & 960.7 & -165.3 \\
\hline 6941101 & Uvalde & 99.9606 & 29.3442 & 1,012 & 961.8 & -50.2 \\
\hline 6941502 & Uvalde & 99.9483 & 29.3183 & 983 & 937.2 & -45.8 \\
\hline 6943910 & Uvalde & 99.6400 & 29.2503 & 876 & 839.4 & -36.6 \\
\hline 6941701 & Uvalde & 99.9711 & 29.2603 & 938 & 904.0 & -34.0 \\
\hline 6943202 & Uvalde & 99.6994 & 29.3592 & 948 & 916.3 & -31.7 \\
\hline 6943103 & Uvalde & 99.7100 & 29.3478 & 924 & 899.0 & -25.0 \\
\hline 6937402 & Uvalde & 99.4700 & 29.4411 & 860 & 836.9 & -23.1 \\
\hline 6943902 & Uvalde & 99.6333 & 29.2761 & 886 & 869.7 & -16.3 \\
\hline 6941504 & Uvalde & 99.9336 & 29.2967 & 934 & 918.3 & -15.7 \\
\hline 6941901 & Uvalde & 99.8803 & 29.2850 & 906 & 893.1 & -12.9 \\
\hline 6944703 & Uvalde & 99.5950 & 29.2586 & 810 & 806.9 & -3.1 \\
\hline 6943804 & Uvalde & 99.6917 & 29.2767 & 885 & 882.9 & -2.1 \\
\hline 6950202 & Uvalde & 99.7981 & 29.2372 & 887 & 887.4 & .4 \\
\hline 6950204 & Uvalde & 99.8247 & 29.2203 & 887 & 887.7 & .7 \\
\hline 6950408 & Uvalde & 99.8603 & 29.2042 & 886 & 888.2 & 2.2 \\
\hline 6950306 & Uvalde & 99.7522 & 29.2322 & 884 & 886.3 & 2.3 \\
\hline 6951104 & Uvalde & 99.7467 & 29.2358 & 883 & 886.3 & 3.3 \\
\hline 6944301 & Uvalde & 99.5117 & 29.3494 & 808 & 811.9 & 3.9 \\
\hline 6950302 & Uvalde & 99.7867 & 29.2103 & 881 & 886.2 & 5.2 \\
\hline 6942907 & Uvalde & 99.7533 & 29.2828 & 881 & 887.3 & 6.3 \\
\hline 6942601 & Uvalde & 99.7508 & 29.3150 & 879 & 888.3 & 9.3 \\
\hline 6951602 & Uvalde & 99.6600 & 29.1756 & 826 & 837.2 & 11.2 \\
\hline 6950403 & Uvalde & 99.8367 & 29.1908 & 875 & 886.6 & 11.6 \\
\hline 6951202 & Uvalde & 99.6719 & 29.2331 & 843 & 858.6 & 15.6 \\
\hline
\end{tabular}


Table 14. Transient simulation target wells and residuals for above-normal rainfall and recharge conditions, Edwards aquifer model, San Antonio region, Texas-Continued.

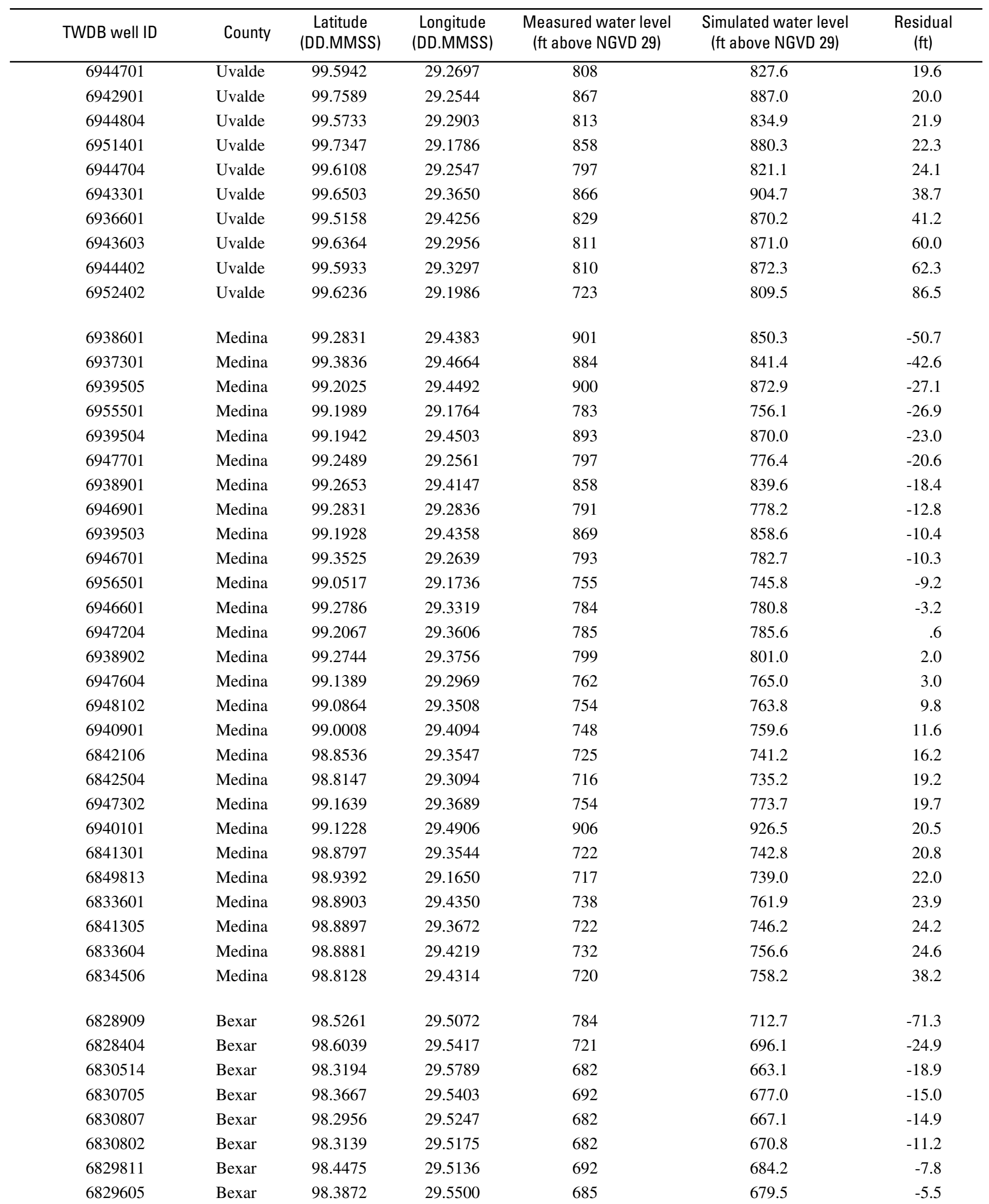


Table 14. Transient simulation target wells and residuals for above-normal rainfall and recharge conditions, Edwards aquifer model, San Antonio region, Texas-Continued.

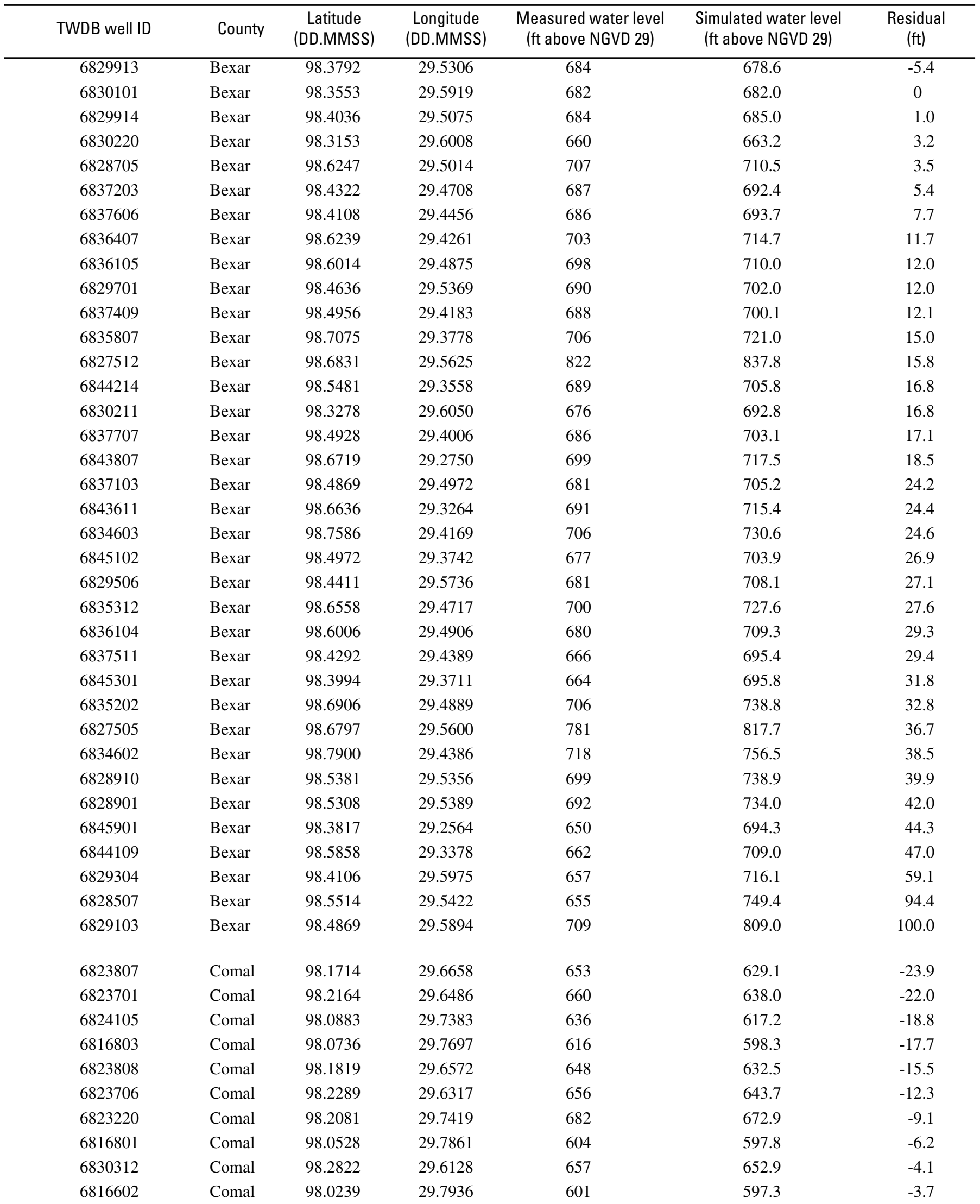


Table 14. Transient simulation target wells and residuals for above-normal rainfall and recharge conditions, Edwards aquifer model, San Antonio region, Texas-Continued.

\begin{tabular}{|c|c|c|c|c|c|c|}
\hline TWDB well ID & County & $\begin{array}{c}\text { Latitude } \\
\text { (DD.MMSS) }\end{array}$ & $\begin{array}{l}\text { Longitude } \\
\text { (DD.MMSS) }\end{array}$ & $\begin{array}{c}\text { Measured water level } \\
\text { (ft above NGVD 29) }\end{array}$ & $\begin{array}{c}\text { Simulated water level } \\
\text { (ft above NGVD 29) }\end{array}$ & $\begin{array}{l}\text { Residual } \\
\text { (ft) }\end{array}$ \\
\hline 6816501 & Comal & 98.0433 & 29.7972 & 597 & 596.6 & -0.4 \\
\hline 6822903 & Comal & 98.2597 & 29.6267 & 647 & 647.6 & .6 \\
\hline 6823206 & Comal & 98.1819 & 29.7483 & 655 & 657.2 & 2.2 \\
\hline 6823101 & Comal & 98.2106 & 29.7403 & 682 & 684.3 & 2.3 \\
\hline 6823306 & Comal & 98.1528 & 29.7464 & 650 & 652.9 & 2.9 \\
\hline 6815902 & Comal & 98.1397 & 29.7592 & 645 & 653.2 & 8.2 \\
\hline 6816703 & Comal & 98.0928 & 29.7531 & 606 & 615.5 & 9.5 \\
\hline 6815903 & Comal & 98.1414 & 29.7575 & 641 & 652.9 & 11.9 \\
\hline 6823202 & Comal & 98.2006 & 29.7111 & 652 & 672.1 & 20.1 \\
\hline 6830208 & Comal & 98.3194 & 29.6097 & 674 & 695.9 & 21.9 \\
\hline 6816701 & Comal & 98.1044 & 29.7572 & 612 & 637.8 & 25.8 \\
\hline 6823302 & Comal & 98.1389 & 29.7161 & 628 & 662.3 & 34.3 \\
\hline 6824104 & Comal & 98.1017 & 29.7472 & 616 & 654.0 & 38.0 \\
\hline 6824102 & Comal & 98.1069 & 29.7444 & 609 & 654.0 & 45.0 \\
\hline 6822501 & Comal & 98.2931 & 29.6800 & 684 & 755.6 & 71.6 \\
\hline 6822301 & Comal & 98.2578 & 29.7119 & 681 & 763.0 & 82.0 \\
\hline 6808601 & Hays & 98.0278 & 29.9458 & 810 & 680.0 & -130.0 \\
\hline 5849911 & Hays & 97.8894 & 30.1328 & 629 & 594.6 & -34.4 \\
\hline 5858104 & Hays & 97.8486 & 30.1042 & 623 & 595.9 & -27.1 \\
\hline 5858101 & Hays & 97.8422 & 30.0836 & 637 & 610.5 & -26.5 \\
\hline 5857902 & Hays & 97.8958 & 30.0083 & 614 & 606.3 & -7.7 \\
\hline 6702103 & Hays & 97.8725 & 29.9889 & 598 & 593.6 & -4.4 \\
\hline 5858406 & Hays & 97.8558 & 30.0614 & 624 & 620.0 & -4.0 \\
\hline 6709110 & Hays & 97.9819 & 29.8431 & 590 & 590.4 & .4 \\
\hline 6816605 & Hays & 98.0042 & 29.8289 & 588 & 590.9 & 2.9 \\
\hline 6701203 & Hays & 97.9206 & 29.9619 & 598 & 602.7 & 4.7 \\
\hline 6701304 & Hays & 97.8761 & 29.9844 & 586 & 593.5 & 7.5 \\
\hline 6709102 & Hays & 97.9758 & 29.8508 & 580 & 590.2 & 10.2 \\
\hline 6701809 & Hays & 97.9286 & 29.9119 & 587 & 598.5 & 11.5 \\
\hline 6701305 & Hays & 97.8872 & 29.9675 & 578 & 592.9 & 14.9 \\
\hline 6701701 & Hays & 97.9639 & 29.8956 & 579 & 605.6 & 26.6 \\
\hline 6701401 & Hays & 97.9642 & 29.9500 & 600 & 628.6 & 28.6 \\
\hline 5857903 & Hays & 97.8861 & 30.0381 & 587 & 619.7 & 32.7 \\
\hline 6816301 & Hays & 98.0214 & 29.8714 & 606 & 640.6 & 34.6 \\
\hline 6701501 & Hays & 97.9475 & 29.9236 & 577 & 617.3 & 40.3 \\
\hline \multicolumn{7}{|l|}{ Statistics: } \\
\hline Mean absolute difference & & & & & & 23.5 \\
\hline Mean algebraic difference & & & & & & 3.5 \\
\hline RMS error & & & & & & 33.5 \\
\hline
\end{tabular}


Table 15. Simulated water budget for the steady-state simulation and for the transient simulation by monthly stress period for 1956 and 1975 , Edwards aquifer model, San Antonio region, Texas.

[acre-ft/yr, acre feet per year; acre-ft/mo, acre feet per month. Recharge includes leakage from streams through streambeds and infiltration of rainfall in interstream areas. Boundary inflow includes inflow through general-head and specifiedflux boundary condition cells at northern and northwestern model boundaries. Stream-aquifer leakage is between Edwards aquifer and Colorado River at northeastern model boundary. Subtotal includes source or discharge components exclusive of changes in storage. Total includes changes in storage. Percent in parentheses excludes change in storage from computation of percent of total sources or percent of total discharges and is percent of subtotal.] exclusive of changes in storage. Total includes changes in storage. Percent in parentheses excludes change in storage from computation of percent of total souction
Steady-state simulation

\begin{tabular}{|c|c|c|c|c|c|c|c|c|c|c|c|c|c|c|}
\hline \multirow{5}{*}{$\begin{array}{c}\text { Budget } \\
\text { component }\end{array}$} & \multirow{2}{*}{\multicolumn{2}{|c|}{$\begin{array}{c}\text { Steady-state simulation } \\
\text { Source }\end{array}$}} & \multicolumn{12}{|c|}{ Transient simulation } \\
\hline & & & \multicolumn{12}{|c|}{ Sources } \\
\hline & \multirow{3}{*}{$\begin{array}{l}\text { Flow rate } \\
\text { (acre-ft/yr) }\end{array}$} & \multirow{3}{*}{$\begin{array}{l}\text { Percent of } \\
\text { total sources }\end{array}$} & & & & & & Stress perio & d (month) & & & & & \\
\hline & & & \multicolumn{2}{|c|}{ January } & \multicolumn{2}{|c|}{ February } & \multicolumn{2}{|c|}{ March } & \multicolumn{2}{|c|}{ April } & \multicolumn{2}{|c|}{ May } & \multicolumn{2}{|c|}{ June } \\
\hline & & & $\begin{array}{l}\text { Flow rate } \\
\text { (acre-ft/mo) }\end{array}$ & $\begin{array}{c}\text { Percent of } \\
\text { total sources } \\
\text { (or subtotal) }\end{array}$ & $\begin{array}{l}\text { Flow rate } \\
\text { (acre-ft/mo) }\end{array}$ & $\begin{array}{c}\text { Percent of } \\
\text { total sources } \\
\text { (or subtotal) }\end{array}$ & $\begin{array}{l}\text { Flow rate } \\
\text { (acre-ft/mo) }\end{array}$ & $\begin{array}{c}\text { Percent of } \\
\text { total sources } \\
\text { (or subtotal) }\end{array}$ & $\begin{array}{c}\text { Flow rate } \\
\text { (acre-ft/mo) }\end{array}$ & $\begin{array}{c}\text { Percent of } \\
\text { total sources } \\
\text { (or subtotal) }\end{array}$ & $\begin{array}{l}\text { Flow rate } \\
\text { (acre-ft/mo) }\end{array}$ & $\begin{array}{c}\text { Percent of } \\
\text { total sources } \\
\text { (or subtotal) }\end{array}$ & $\begin{array}{l}\text { Flow rate } \\
\text { (acre-ft/mo) }\end{array}$ & $\begin{array}{l}\text { Percent of } \\
\text { total sources } \\
\text { (or subtotal) }\end{array}$ \\
\hline \multicolumn{15}{|l|}{ Recharge } \\
\hline Steady-state & $583,985.9$ & 93.5 & & & & & & & & & & & & \\
\hline $1956^{\circ}$ & & & $7,576.4$ & $26.4(69.2)$ & $7,173.4$ & $27.7(70.2)$ & $6,965.2$ & $20.9(67.4)$ & $5,602.7$ & $17.0(63.2)$ & $5,168.4$ & $14.4(60.5)$ & $3,148.2$ & $7.0(49.1)$ \\
\hline 1975 & & & $62,874.8$ & $92.5(95.2)$ & $224,897.5$ & 98.7 & $81,454.5$ & 96.2 & $60,633.9$ & $76.1(95.2)$ & $230,217.2$ & 98.6 & $111,236.2$ & 97.3 \\
\hline \multicolumn{15}{|l|}{ Boundary inflow } \\
\hline $\begin{array}{l}\text { Steady-state } \\
1956\end{array}$ & $40,265.3$ & 6.5 & & & & & & & & & & & & \\
\hline $\begin{array}{l}1956 \\
1975\end{array}$ & & & $\begin{array}{l}3,357.1 \\
3,181.8\end{array}$ & $\begin{array}{c}11.7(30.7) \\
47(4.8)\end{array}$ & $\begin{array}{l}3,032.2 \\
28739\end{array}$ & $11.7(29.7)$ & $\begin{array}{l}3,353.7 \\
3,1818\end{array}$ & $10.1(32.5)$ & $\begin{array}{l}3,245.5 \\
3079 ?\end{array}$ & $\begin{array}{l}9.8(36.6) \\
39(4.8)\end{array}$ & $\begin{array}{l}3,353.7 \\
3,81.8\end{array}$ & $9.3(39.3)$ & $\begin{array}{l}3,242.1 \\
3079 ?\end{array}$ & $7.2(50.6)$ \\
\hline \multicolumn{15}{|c|}{ Stream-aquifer leakage } \\
\hline Steady-state & 0 & 0 & & & & & & & & & & & & \\
\hline 1956 & & & 13.7 & $.05(.13)$ & 12.7 & $.05(.12)$ & 14.2 & $.04(.14)$ & 14.3 & $.04(.16)$ & 15.1 & $.04(.18)$ & 15.1 & $.03(.24)$ \\
\hline 1975 & & & 0 & 0 & 0 & 0 & 0 & 0 & 0 & 0 & 0 & 0 & 0 & 0 \\
\hline \multicolumn{15}{|l|}{ Subtotal } \\
\hline 1956 & & & $10,947.2$ & 38.2 & $10,218.2$ & 39.4 & $10,333.2$ & 31.0 & $8,862.6$ & 26.9 & $8,537.2$ & 23.8 & $6,405.4$ & 14.2 \\
\hline 1975 & & & $66,056.6$ & 97.2 & $227,771.4$ & 100.0 & $84,636.3$ & 100.0 & $63,713.0$ & 80.0 & $233,399.0$ & 100.0 & $114,315.4$ & 100.0 \\
\hline Total steady-state & $624,251.2$ & 100.0 & & & & & & & & & & & & \\
\hline 1956 & & & $28,682.8$ & 100.0 & $25,918.8$ & 100.0 & $33,341.4$ & 100.0 & $32,987.1$ & 100.0 & $35,924.1$ & 100.0 & $44,977.2$ & 100.0 \\
\hline 1975 & & & $67,936.9$ & 100.0 & $227,771.4$ & 100.0 & $84,636.3$ & 100.0 & $79,690.1$ & 100.0 & $233,399.0$ & 100.0 & $114,315.4$ & 100.0 \\
\hline \multirow{5}{*}{$\begin{array}{l}\text { Budget } \\
\text { component }\end{array}$} & \multicolumn{2}{|c|}{ Steady-state simulation } & & & & & & Transient & simulation & & & & & \\
\hline & & ource & & & & & & Disch & $\operatorname{arges}$ & & & & & \\
\hline & & & & & & & & Stress peri & od (month) & & & & & \\
\hline & & & & nuary & & bruary & & Иarch & & April & & May & & June \\
\hline & (acre-ft/yr) & total discharges & $\begin{array}{c}\text { Flow rate } \\
\text { (acre-ft/mo) }\end{array}$ & $\begin{array}{c}\text { Percent of } \\
\text { total discharges } \\
\text { (or subtotal) }\end{array}$ & $\begin{array}{c}\text { Flow rate } \\
\text { (acre-ft/mo) }\end{array}$ & $\begin{array}{c}\text { Percent of } \\
\text { total discharges } \\
\text { (or subtotal) } \\
\end{array}$ & $\begin{array}{c}\text { Flow rate } \\
\text { (acre-ft/mo) }\end{array}$ & $\begin{array}{c}\text { Percent of } \\
\text { total discharges } \\
\text { (or subtotal) }\end{array}$ & $\begin{array}{l}\text { Flow rate } \\
\text { (acre-ft/mo) }\end{array}$ & $\begin{array}{c}\text { Percent of } \\
\text { total discharges } \\
\text { (or subtotal) }\end{array}$ & $\begin{array}{l}\text { Flow rate } \\
\text { (acre-ft/mo) }\end{array}$ & $\begin{array}{l}\text { Percent of } \\
\text { total discharges } \\
\text { (or subtotal) }\end{array}$ & $=\begin{array}{c}\text { Flow rate } \\
\text { (acre-ft/mo) }\end{array}$ & $\begin{array}{l}\text { Percent of } \\
\text { total discharges } \\
\text { (or subtotal) }\end{array}$ \\
\hline Withdrawals (p & sumpage) & & & & & & & & & & & & & \\
\hline Steady-state & $160,592.5$ & 25.7 & & & & & & & & & & & & \\
\hline 1956 & & & $15,510.8$ & 54.1 & $14,024.5$ & 54.1 & $20,818.6$ & 62.4 & $21,582.0$ & 65.4 & $25,800.1$ & 71.8 & $37,855.3$ & 84.2 \\
\hline $\begin{array}{l}1975 \\
\quad \text { Springflow }\end{array}$ & & & $15,700.6$ & 23.1 & $14,703.6$ & $6.5(21.8)$ & $22,013.0$ & $26.0(27.0)$ & $22,763.9$ & 28.6 & $26,519.3$ & $11.4(30.1)$ & $40,358.3$ & $35.3(40.7)$ \\
\hline Steady-state & $460,169.3$ & 73.7 & & & & & & & & & & & & \\
\hline 1956 & & & $13,007.4$ & 45.3 & $11,748.4$ & 45.3 & $12,360.7$ & 37.1 & $11,248.7$ & 34.1 & $9,964.2$ & 27.7 & $6,967.8$ & 15.5 \\
\hline 1975 & & & $51,893.6$ & 76.4 & $52,452.6$ & $23.0(77.7)$ & $59,045.8$ & $69.8(72.5)$ & $56,588.0$ & 71.0 & $61,193.6$ & $26.2(69.5)$ & $58,457.3$ & $51.1(58.9)$ \\
\hline Stream-aquifer & rleakage & & & & & & & & & & & & & \\
\hline Steady-state & $3,488.7$ & 0.6 & & & & & & & & & & & & \\
\hline $1956^{\circ}$ & & & 164.9 & .6 & 147.7 & .6 & 162.8 & .5 & 155.6 & .5 & 159.9 & .4 & 152.9 & .3 \\
\hline 1975 & & & 341.7 & .5 & 312.3 & $.1(.5)$ & 347.9 & $.4(.4)$ & 337.5 & .4 & 351.2 & $.2(.4)$ & 355.1 & $.3(.4)$ \\
\hline Subtotal & & & & & & & & & & & & & & \\
\hline 1956 & & & $28,683.1$ & 100.0 & $25,920.6$ & 100.0 & $33,342.2$ & 100.0 & $32,986.2$ & 100.0 & $35,924.2$ & 100.0 & $44,975.9$ & 100.0 \\
\hline 1975 & & & $67,935.9$ & 100.0 & $67,468.6$ & 29.6 & $81,406.7$ & 96.2 & $79,689.5$ & 100.0 & $88,064.1$ & 37.7 & $99,170.6$ & 86.8 \\
\hline Total steady-state & $624,250.5$ & 100.0 & & & & & & & & & & & & \\
\hline 1956 & & & $28,683.1$ & 100.0 & $25,920.6$ & 100.0 & $33,342.2$ & 100.0 & $32,986.2$ & 100.0 & $35,924.2$ & 100.0 & $44,975.9$ & 100.0 \\
\hline 1975 & & & $67,935.9$ & 100.0 & $227,772.4$ & 100.0 & $84,636.6$ & 100.0 & $79,689.5$ & 100.0 & $233,398.9$ & 100.0 & $114,314.2$ & 100.0 \\
\hline Change in st & torage & & & & & & & & & & & & & \\
\hline 1956 & & & $-17,735.6$ & ${ }^{1} 61.8$ & $-15,700.5$ & ${ }^{1} 60.6$ & $-23,008.3$ & ${ }^{1} 69.0$ & $-24,124.5$ & ${ }^{1} 73.1$ & $-27,386.9$ & ${ }^{1} 76.2$ & $-38,571.8$ & ${ }^{1} 85.8$ \\
\hline 1975 & & & $-1,880.3$ & ${ }^{1} 2.8$ & $160,303.9$ & ${ }^{2} 70.4$ & $3,229.9$ & ${ }^{2} 3.8$ & $-15,977.0$ & ${ }^{1} 20.0$ & $145,334.8$ & ${ }^{2} 62.3$ & $15,143.6$ & ${ }^{2} 13.2$ \\
\hline
\end{tabular}

Footnotes at end of table. 
Table 15. Simulated water budget for the steady-state simulation and for the transient simulation by monthly stress period for 1956 and 1975, Edwards aquifer model, San Antonio region, Texas-Continued.

\begin{tabular}{|c|c|c|c|c|c|c|c|c|c|c|c|c|c|c|}
\hline \multirow{5}{*}{$\begin{array}{c}\text { Budget } \\
\text { component }\end{array}$} & \multicolumn{14}{|c|}{ Transient simulation } \\
\hline & \multicolumn{14}{|c|}{ Sources } \\
\hline & \multirow{2}{*}{\multicolumn{4}{|c|}{ August }} & \multirow{2}{*}{\multicolumn{4}{|c|}{$\frac{\text { Stress period (month) }}{\text { October }}$}} & & & & & & \\
\hline & & & & & & & & & \multicolumn{2}{|c|}{ November } & \multicolumn{2}{|c|}{ December } & \multicolumn{2}{|c|}{ Annual total } \\
\hline & $\begin{array}{c}\text { Flow rate } \\
\text { (acre-ft/mo) }\end{array}$ & $\begin{array}{c}\text { Percent of } \\
\text { total sources } \\
\text { (or subtotal) }\end{array}$ & $\begin{array}{l}\text { Flow rate } \\
\text { (acre-ft/mo) }\end{array}$ & $\begin{array}{l}\text { Percent of } \\
\text { total sources } \\
\text { (or subtotal) }\end{array}$ & $\begin{array}{l}\text { Flow rate } \\
\text { (acre-ft/mo) }\end{array}$ & $\begin{array}{c}\text { Percent of } \\
\text { total sources } \\
\text { (or subtotal) }\end{array}$ & $\begin{array}{l}\text { Flow rate } \\
\text { (acre-ft/mo) }\end{array}$ & $\begin{array}{c}\text { Percent of } \\
\text { total sources } \\
\text { (or subtotal) }\end{array}$ & $\begin{array}{l}\text { Flow rate } \\
\text { (acre-ft/mo) }\end{array}$ & $\begin{array}{l}\text { Percent of } \\
\text { total sources } \\
\text { (or subtotal) }\end{array}$ & $\begin{array}{l}\text { Flow rate } \\
\text { (acre-ft/mo) }\end{array}$ & $\begin{array}{l}\text { Percent of } \\
\text { total sources } \\
\text { (or subtotal) }\end{array}$ & $\begin{array}{l}\text { Flow rate } \\
\text { (acre-ft/mo) }\end{array}$ & $\begin{array}{l}\text { Percent of } \\
\text { total sources } \\
\text { (or subtotal) }\end{array}$ \\
\hline \multirow{2}{*}{\multicolumn{15}{|c|}{$\begin{array}{l}\text { Recharge } \\
\text { Steady-state }\end{array}$}} \\
\hline & & & & & & & & & & & & & & \\
\hline $1956^{\circ}$ & $5,159.4$ & $9.5(60.5)$ & $3,450.4$ & $6.7(50.6)$ & $2,638.7$ & $8.1(44.8)$ & $5,045.3$ & $18.6(60.0)$ & $4,635.9$ & $19.2(58.8)$ & $3,895.4$ & $15.5(53.7)$ & $60,459.5$ & $14.5(60.4)$ \\
\hline \multicolumn{15}{|l|}{ Boundary inflow } \\
\hline Steady-state & & & & & & & & & & & & & & \\
\hline $1956^{\circ}$ & $3,350.2$ & $6.2(39.3)$ & $3,350.2$ & $6.5(49.1)$ & $3,242.1$ & $10.0(55.0)$ & $3,346.1$ & $12.3(39.8)$ & $3,238.2$ & $13.4(41.0)$ & $3,346.1$ & $13.3(46.1)$ & $39,457.3$ & $9.5(39.4)$ \\
\hline 1975 & $3,181.8$ & $2.9(3.1)$ & $3,181.8$ & $3.0(6.0)$ & $3,079.2$ & $3.7(8.5)$ & $3,181.8$ & $4.1(6.4)$ & $3,079.2$ & $4.3(8.6)$ & $3,181.8$ & $4.4(9.6)$ & $37,463.2$ & $2.8(3.4)$ \\
\hline \multicolumn{15}{|c|}{ Stream-aquifer leakage } \\
\hline Steady-state & & & & & & & & & & & & & & \\
\hline 1956 & 16.0 & .03(.19) & 16.3 & .03 (.24) & 15.6 & .05 (.26) & 15.7 & $.06(.19)$ & 14.7 & $.06(.19)$ & 15.6 & $.06(.21)$ & 179.0 & $.04(.18)$ \\
\hline 1975 & 0 & 0 & 0 & 0 & 0 & 0 & 0 & 0 & 0 & 0 & 0 & 0 & 0 & 0 \\
\hline \multicolumn{15}{|l|}{ Subtotal } \\
\hline 1956 & $8,525.6$ & 15.7 & $6,816.9$ & 13.3 & $5,896.5$ & 18.2 & $8,407.2$ & 31.0 & $7,888.8$ & 32.7 & $7,257.1$ & 28.9 & $100,095.8$ & 24.1 \\
\hline 1975 & $102,670.0$ & 92.1 & $53,133.1$ & 50.5 & $36,085.8$ & 43.6 & $49,741.8$ & 63.7 & $35,968.9$ & 50.0 & $33,196.9$ & 45.5 & $1,100,688.3$ & 82.8 \\
\hline \multirow{2}{*}{\multicolumn{15}{|c|}{ Total }} \\
\hline Steady-state & & & & & & & & & & & & & & \\
\hline $1956^{\circ}$ & $54,176.5$ & 100.0 & $51,193.6$ & 100.0 & $32,478.4$ & 100.0 & $27,095.7$ & 100.0 & $24,114.3$ & 100.0 & $25,146.3$ & 100.0 & $416,036.3$ & 100.0 \\
\hline 1975 & $111,508.1$ & 100.0 & $105,155.6$ & 100.0 & $82,684.4$ & 100.0 & $78,119.7$ & 100.0 & $71,963.8$ & 100.0 & $72,919.8$ & 100.0 & $1,330,100.4$ & 100.0 \\
\hline
\end{tabular}

\begin{tabular}{|c|c|c|c|c|c|c|c|c|c|c|c|c|c|c|}
\hline \multirow{4}{*}{$\begin{array}{c}\text { Budget } \\
\text { component }\end{array}$} & \multicolumn{14}{|c|}{$\frac{\text { Transient simulation }}{\text { Discharges }}$} \\
\hline & \multicolumn{14}{|c|}{ Stress period (month) } \\
\hline & \multicolumn{2}{|r|}{ July } & \multicolumn{2}{|c|}{ August } & \multicolumn{2}{|c|}{ September } & \multicolumn{2}{|c|}{ October } & \multicolumn{2}{|c|}{ November } & \multicolumn{2}{|c|}{ December } & \multicolumn{2}{|c|}{ Annual total } \\
\hline & $\begin{array}{c}\text { Flow rate } \\
\text { (acre-ft/mo) }\end{array}$ & $\begin{array}{c}\text { Percent of } \\
\text { total discharges } \\
\text { (or subtotal) }\end{array}$ & $\begin{array}{l}\text { Flow rate } \\
\text { (acre-ft/mo) }\end{array}$ & $\begin{array}{c}\text { Percent of } \\
\text { total discharges } \\
\text { (or subtotal) }\end{array}$ & $\begin{array}{c}\text { Flow rate } \\
\text { (acre-ft/mo) }\end{array}$ & $\begin{array}{c}\text { Percent of } \\
\text { total discharges } \\
\text { (or subtotal) }\end{array}$ & $\begin{array}{l}\text { Flow rate } \\
\text { (acre-ft/mo) }\end{array}$ & $\begin{array}{c}\text { Percent of } \\
\text { total discharges } \\
\text { (or subtotal) }\end{array}$ & $\begin{array}{l}\text { Flow rate } \\
\text { (acre-ft/mo) }\end{array}$ & $\begin{array}{c}\text { Percent of } \\
\text { total discharges } \\
\text { (or subtotal) }\end{array}$ & $\begin{array}{l}\text { Flow rate } \\
\text { (acre-ft/mo) }\end{array}$ & $\begin{array}{c}\text { Percent of } \\
\text { total discharges } \\
\text { (or subtotal) }\end{array}$ & $\begin{array}{c}\text { Flow rate } \\
\text { (acre-ft/mo) }\end{array}$ & $\begin{array}{l}\text { Percent of } \\
\text { total discharges } \\
\text { (or subtotal) }\end{array}$ \\
\hline \multirow{2}{*}{\multicolumn{15}{|c|}{$\begin{array}{l}\text { Withdrawals (pumpage) } \\
\text { Steady-state }\end{array}$}} \\
\hline & & & & & & & & & & & & & & \\
\hline $1956^{\circ}$ & $48,535.3$ & 89.6 & $46,094.2$ & 90.0 & $27,246.8$ & 83.9 & $20,180.9$ & 74.5 & $15,834.9$ & 65.7 & $15,694.4$ & 62.4 & $309,177.7$ & 74.3 \\
\hline \multirow{2}{*}{\multicolumn{15}{|c|}{ Springflow }} \\
\hline & & & & & & & & & & & & & & \\
\hline $\begin{array}{l}\text { Steady-state } \\
1956\end{array}$ & $5,484.9$ & \multicolumn{2}{|c|}{ Steady-state } & 9.7 & $5,079.8$ & 15.6 & $6,757.6$ & 24.9 & $8,125.0$ & 33.7 & $9,295.5$ & 37.0 & & 25.2 \\
\hline 1975 & $57,723.3$ & 51.8 & $54,611.3$ & 51.9 & $53,743.0$ & 65.0 & $56,969.5$ & 72.9 & $55,545.5$ & 77.2 & $56,646.7$ & 77.7 & $674,870.2$ & $50.7(67.1)^{4} 61.3$ \\
\hline \multirow{2}{*}{\multicolumn{15}{|c|}{$\begin{array}{l}\text { Stream-aquifer leakage } \\
\text { Steady-state }\end{array}$}} \\
\hline & & & & & & & & & & & & & & \\
\hline 1956 & 156.3 & .3 & 155.1 & .3 & 150.5 & .5 & 156.3 & .6 & 152.9 & .6 & 156.5 & .6 & $1,871.4$ & \\
\hline \multicolumn{15}{|l|}{ Subtotal } \\
\hline 1956 & $54,176.4$ & 100.0 & $51,192.8$ & 100.0 & $32,477.1$ & 100.0 & $27,094.8$ & 100.0 & $24,112.9$ & 100.0 & $25,146.4$ & 100.0 & $416,032.7$ & 100.0 \\
\hline 1975 & $111,507.9$ & 100.0 & $105,155.8$ & 100.0 & $82,682.0$ & 100.0 & $78,118.5$ & 100.0 & $71,962.1$ & 100.0 & $72,918.7$ & 100.0 & $1,006,080.4$ & $75.6^{4} 91.4$ \\
\hline \multicolumn{15}{|l|}{ Total } \\
\hline \multicolumn{15}{|l|}{ Steady-state } \\
\hline $1956^{\circ}$ & $54,176.4$ & 100.0 & $51,192.8$ & 100.0 & $32,477.1$ & 100.0 & $27,094.8$ & 100.0 & $24,112.9$ & 100.0 & $25,146.4$ & 100.0 & $416,032.7$ & 100.0 \\
\hline 1975 & $111,507.9$ & 100.0 & $105,155.8$ & 100.0 & $82,682.0$ & 100.0 & $78,118.5$ & 100.0 & $71,962.1$ & 100.0 & $72,918.7$ & 100.0 & $1,330,092.7$ & 100.0 \\
\hline \multicolumn{15}{|c|}{ Change in storage } \\
\hline 1956 & $-45,650.9$ & ${ }^{1} 84.3$ & $-44,376.7$ & ${ }^{1} 86.7$ & $-26,581.9$ & ${ }^{1} 81.8$ & $-18,688.5$ & ${ }^{1} 69.0$ & $-16,225.5$ & ${ }^{1} 67.3$ & $-17,889.2$ & ${ }^{1} 71.1$ & ${ }^{3}-315,940.5$ & ${ }^{1} 75.9$ \\
\hline 1975 & $-8,838.1$ & ${ }^{1} 7.9$ & $-52,022.6$ & ${ }^{1} 49.5$ & $-46,598.5$ & ${ }^{1} 56.4$ & $-28,377.8$ & ${ }^{1} 36.3$ & $-35,994.9$ & ${ }^{1} 50.0$ & $-39,722.9$ & ${ }^{1} 54.5$ & 394,600 & ${ }^{2} 7.1^{4} 8.6$ \\
\hline
\end{tabular}

${ }^{1}$ Net change in storage as a percent of total sources (storage is included as a source in those months in which there $\quad{ }^{3}$ Annual net change in storage; for 1956 net equals total because there was a net loss from storage in each month of was a net loss from storage) 1956.

${ }^{4}$ Percent of quantity (annual discharges subtotal plus annual net change in storage). This annual percent is consis${ }^{2}$ Net change in storage as a percent of total discharges (storage is included as a discharge in those months in which tent with corresponding monthly percent of total discharges for months in which storage is included as a discharge- - those months in which there was a net gain to storage. 
Table 16. Comparison of the residuals for hydraulic heads and springflows for selected observation wells and springs for the Edwards aquifer model and the GWSIM model, San Antonio region, Texas.

[TWDB, Texas Water Development Board; ID, identification number; ft, feet; MAE, mean absolute difference (sum of absolute values of differences between measured and simulated hydraulic heads and springflows [residuals, simulated minus measured] divided by number of measurements); RMS error, root mean square error; NA, not applicable; $\mathrm{ft}^{3} / \mathrm{d}$, cubic feet per day. Well name is as specified in LBG-Guyton Associates (1996). Time period refers to time period for which measured and simulated hydraulic heads and springflows are compared. Hydrologic condition: $\mathrm{U}$, unconfined conditions at well site; C, confined conditions at well site. Range refers to range in measured hydraulic heads or springflows for time period of comparison.]

\begin{tabular}{|c|c|c|c|c|c|c|c|c|c|}
\hline \multirow{3}{*}{ County } & \multirow[t]{3}{*}{ Well name } & \multirow{3}{*}{$\begin{array}{l}\text { TWDB } \\
\text { well ID }\end{array}$} & \multirow{3}{*}{$\begin{array}{l}\text { Hydrologic } \\
\text { condition }\end{array}$} & \multicolumn{6}{|c|}{$\begin{array}{l}\text { Hydraulic head residuals } \\
\text { (ft) }\end{array}$} \\
\hline & & & & \multicolumn{3}{|c|}{ Edwards aquifer model } & \multicolumn{3}{|c|}{ GWSIM model } \\
\hline & & & & MAE & RMS & RMS/range & MAE & RMS & RMS/range \\
\hline \multirow[t]{11}{*}{ Bexar } & Hill Country & 6829103 & $\mathrm{U}$ & & & & & & \\
\hline & 1978-89 & & & 42.1 & 59.9 & 1.030 & 19.8 & 21.1 & .364 \\
\hline & Airport & 6829701 & $\mathrm{C}$ & & & & & & \\
\hline & 1978-89 & & & 15.3 & 17.9 & .240 & 6.5 & 8.4 & .113 \\
\hline & $\mathrm{J}-17$ & 6837203 & $\mathrm{C}$ & & & & & & \\
\hline & 1947-59 & & & 4.3 & 5.2 & .079 & 6.1 & 7.4 & .113 \\
\hline & $1978-89$ & & & 7.9 & 9.9 & .145 & 10.4 & 12.7 & .184 \\
\hline & $1947-2000$ & & & 6.2 & 8.0 & .088 & NA & NA & NA \\
\hline & Cibolo Creek & 6830211 & $\mathrm{C} / \mathrm{U}$ & & & & & & \\
\hline & $1978-89$ & & & 15.1 & 17.2 & .300 & 9.0 & 10.7 & .186 \\
\hline & $1964-2000$ & & & 12.8 & 15.4 & .103 & NA & NA & NA \\
\hline \multirow[t]{10}{*}{ Comal } & Jentsch & 6816801 & $\mathrm{U}$ & & & & & & \\
\hline & 1978-89 & & & 13.3 & 13.8 & .510 & 12.1 & 13.3 & .492 \\
\hline & $1947-2000$ & & & 3.4 & 5.0 & .088 & NA & NA & NA \\
\hline & Landa Park & 6823302 & $\mathrm{U}$ & & & & & & \\
\hline & 1978-89 & & & 30.1 & 33.2 & 3.326 & 1.4 & 1.8 & .181 \\
\hline & Bracken & 6830208 & $\mathrm{U} / \mathrm{C}$ & & & & & & \\
\hline & 1978-89 & & & 25.7 & 28.3 & .451 & 4.8 & 6.3 & .101 \\
\hline & Schaeffer & 6823701 & $\mathrm{C}$ & & & & & & \\
\hline & 1978-89 & & & 38.1 & 40.0 & .536 & 25.0 & 27.1 & .363 \\
\hline & 1947-94 & & & 6.7 & 8.7 & .096 & NA & NA & NA \\
\hline \multirow[t]{13}{*}{ Hays } & Gregg & 5857902 & $\mathrm{C}$ & & & & & & \\
\hline & 1978-89 & & & 15.9 & 17.8 & .349 & 10.5 & 12.8 & .250 \\
\hline & Franklin & 5858101 & $\mathrm{C}$ & & & & & & \\
\hline & 1978-89 & & & 23.7 & 26.5 & .268 & 20.2 & 25.5 & .258 \\
\hline & $1947-2000$ & & & 26.2 & 29.2 & .231 & NA & NA & NA \\
\hline & Selberra & 6701304 & $\mathrm{C}$ & & & & & & \\
\hline & 1978-89 & & & 16.6 & 20.2 & .373 & 14.4 & 17.7 & .327 \\
\hline & Knispel & 6701809 & $\mathrm{C}$ & & & & & & \\
\hline & 1978-89 & & & 14.6 & 14.8 & 1.563 & 3.8 & 4.6 & .483 \\
\hline & Nicholson & 6709102 & $\mathrm{C}$ & & & & & & \\
\hline & 1978-89 & & & 10.5 & 10.7 & .796 & 17.0 & 17.3 & 1.288 \\
\hline & SWTSU & 6709110 & $\mathrm{U}$ & & & & & & \\
\hline & 1978-89 & & & 3.2 & 3.4 & .253 & 9.5 & 10.0 & .744 \\
\hline \multirow[t]{11}{*}{ Medina } & Stinson & 6833604 & $\mathrm{C}$ & & & & & & \\
\hline & 1978-89 & & & 13.9 & 17.3 & .174 & 11.6 & 14.0 & .141 \\
\hline & Castroville & 6841301 & $\mathrm{C}$ & & & & & & \\
\hline & 1978-89 & & & 14.7 & 17.4 & .191 & 15.6 & 18.0 & .198 \\
\hline & $1950-2000$ & & & 15.9 & 17.8 & .131 & NA & NA & NA \\
\hline & Seco Creek & 6938601 & $\mathrm{U}$ & & & & & & \\
\hline & $1978-89$ & & & 83.8 & 84.7 & .826 & 17.7 & 21.0 & .205 \\
\hline & Hondo Pool & 6947302 & $\mathrm{C}$ & & & & & & \\
\hline & 1978-89 & & & 16.1 & 19.5 & .174 & 9.6 & 12.5 & .112 \\
\hline & Muenik & 6948102 & $\mathrm{C}$ & & & & & & \\
\hline & 1978-89 & & & 10.7 & 14.0 & .141 & 15.2 & 17.7 & .178 \\
\hline Uvalde & Highway 187 & 6937402 & $\mathrm{U}$ & & & & & & \\
\hline & 1978-89 & & & 41.3 & 42.4 & .348 & 33 & 39.3 & .322 \\
\hline & Knippa & 6943804 & $\mathrm{U}$ & & & & & & \\
\hline & $1978-89$ & & & 61.5 & 79.4 & .344 & 43.2 & 56.8 & .246 \\
\hline & Sabinal & 6945401 & $\mathrm{C}$ & & & & & & \\
\hline & $1978-89$ & & & 17.3 & 21.6 & .172 & 15.3 & 18.8 & .150 \\
\hline & 1954-2000 & & & 11.4 & 14.2 & .083 & NA & NA & NA \\
\hline & UX Cattle & 6950101 & $\mathrm{C}$ & & & & & & \\
\hline & 1978-89 & & & 9.2 & 12.8 & .451 & 8.2 & 11.6 & .408 \\
\hline & JW Heine & 6950202 & $\mathrm{C}$ & & & & & & \\
\hline & $1978-89$ & & & 7.7 & 10.6 & .397 & 7.6 & 10.0 & .375 \\
\hline & Uvalde City & 6950302 & $\mathrm{C}$ & & & & & & \\
\hline & $1978-89$ & & & 7.7 & 9.4 & .296 & 10.1 & 13.6 & .429 \\
\hline & $1947-2000$ & & & 11.7 & 15.0 & .132 & NA & NA & NA \\
\hline & Nueces & 7040901 & $\mathrm{U}$ & & & & & & \\
\hline & $1978-89$ & & & 87.5 & 101.7 & 30.446 & 54.9 & 55.1 & 16.493 \\
\hline & Cline & 7056201 & $\mathrm{C}$ & & & & & & \\
\hline & 1978-89 & & & 40.3 & 40.9 & 1.457 & 29.5 & 30.5 & 1.086 \\
\hline
\end{tabular}


Table 16. Comparison of the residuals for hydraulic heads and springflows for selected observation wells and springs for the Edwards aquifer model and the GWSIM model, San Antonio region, Texas-Continued.

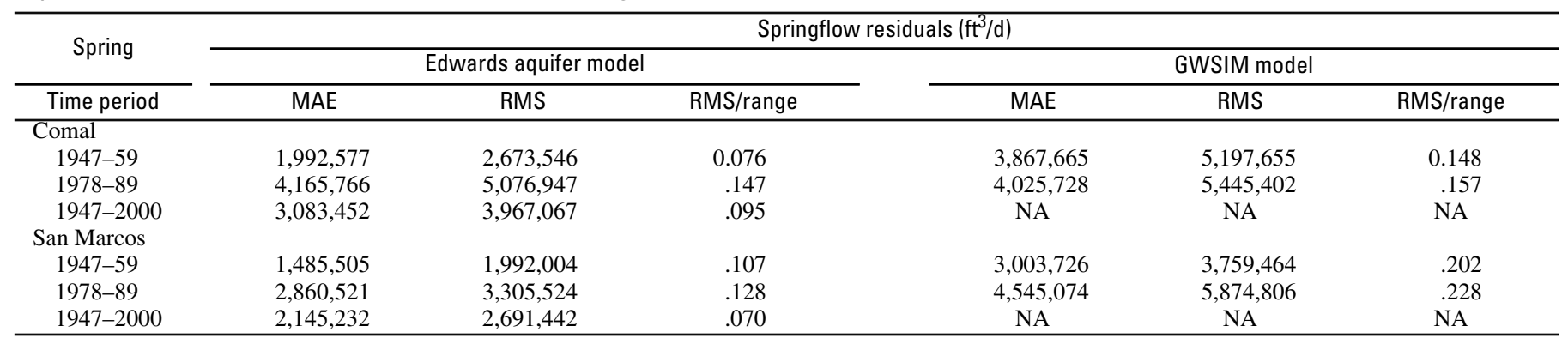


Prepared by the Texas District Office:

U.S. Geological Survey

8027 Exchange Drive

Austin, TX 78754-4733

Information regarding water resources in Texas is available at URL http: //tx.usgs.gov/ 


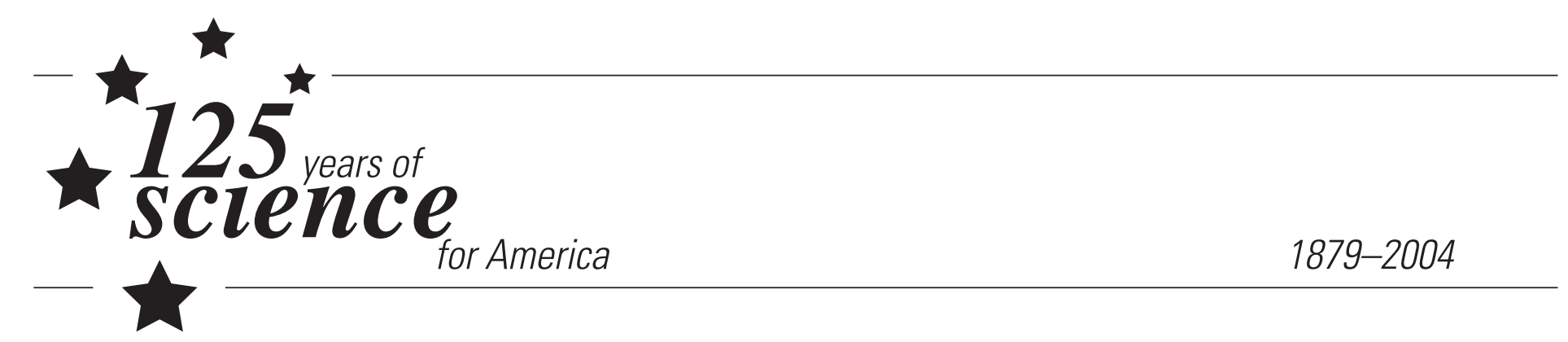

8 Printed on recycled paper 